Portland State University

PDXScholar

$5-2020$

\title{
ADA Accessible Trail Improvement with Naturally Occurring, Sustainable Materials
}

\author{
Matthew D. Sleep \\ Oregon Institute of Technology \\ Damian K. Matzen \\ Oregon Institute of Technology
}

Follow this and additional works at: https://pdxscholar.library.pdx.edu/trec_reports

Part of the Transportation Commons, Urban Studies Commons, and the Urban Studies and Planning Commons

Let us know how access to this document benefits you.

\section{Recommended Citation}

Sleep, Matthew and Matzen, Damian. ADA Accessible Trail Improvement with Naturally Occurring, Sustainable Materials. NITC-RR-1131. Portland, OR: Transportation Research and Education Center (TREC), 2020.: https://doi.org/10.15760/trec.249

This Report is brought to you for free and open access. It has been accepted for inclusion in TREC Final Reports by an authorized administrator of PDXScholar. Please contact us if we can make this document more accessible: pdxscholar@pdx.edu. 


\title{
ADA ACCESSIBLE TRAIL IMPROVEMENT WITH NATURALLY OCCURRING, SUSTAINABLE MATERIALS
}

\author{
Final Report \\ NITC-RR-1131 \\ by \\ Dr. Matthew D. Sleep \\ Damian K. Matzen \\ Oregon Institute of Technology
}

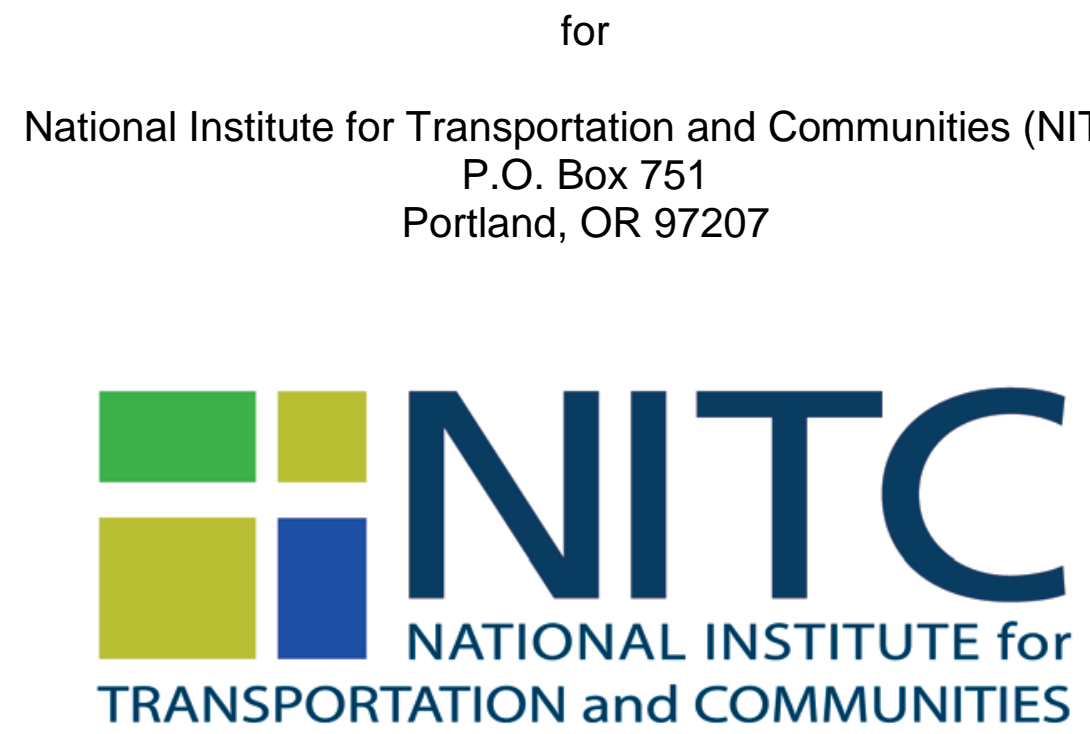

May 2020 


\begin{tabular}{|c|c|c|c|c|}
\hline $\begin{array}{l}\text { Technical Report Docume } \\
\text { 1. Report No. } \\
\text { NITC-RR-1131 }\end{array}$ & \multicolumn{2}{|l|}{ 2. Government Accession No. } & \multicolumn{2}{|c|}{ 3. Recipient's Catalog No. } \\
\hline \multirow{2}{*}{\multicolumn{3}{|c|}{$\begin{array}{l}\text { 4. Title and Subtitle } \\
\text { ADA Accessible Trail Improvement with Naturally Occurring, Sustainable Materials }\end{array}$}} & \multicolumn{2}{|c|}{$\begin{array}{l}\text { 5. Report Date } \\
\text { May } 2020\end{array}$} \\
\hline & & & \multicolumn{2}{|c|}{ 6. Performing Organization Code } \\
\hline \multicolumn{3}{|l|}{$\begin{array}{l}\text { 7. Author(s) } \\
\text { Dr. Matthew Sleep } \\
\text { Damian Matzen }\end{array}$} & \multicolumn{2}{|c|}{$\begin{array}{l}\text { 8. Performing Organization Report } \\
\text { No. }\end{array}$} \\
\hline \multirow{2}{*}{\multicolumn{3}{|c|}{$\begin{array}{l}\text { 9. Performing Organization Name and Address } \\
\text { Oregon Institute of Technology } \\
\text { 3201 Campus Drive } \\
\text { Klamath Falls, OR } 97601\end{array}$}} & \multicolumn{2}{|c|}{ 10. Work Unit No. (TRAIS) } \\
\hline & & & \multicolumn{2}{|c|}{ 11. Contract or Grant No. } \\
\hline \multirow{2}{*}{\multicolumn{3}{|c|}{$\begin{array}{l}\text { 12. Sponsoring Agency Name and Address } \\
\text { National Institute for Transportation and Communities (NITC) } \\
\text { P.O. Box } 751 \\
\text { Portland, OR } 97207\end{array}$}} & \multicolumn{2}{|c|}{$\begin{array}{l}\text { 13. Type of Report and Period } \\
\text { Covered }\end{array}$} \\
\hline & & & \multicolumn{2}{|c|}{ 14. Sponsoring Agency Code } \\
\hline \multicolumn{5}{|l|}{ 15. Supplementary Notes } \\
\hline \multicolumn{5}{|l|}{ 16. Abstract } \\
\hline \multicolumn{5}{|c|}{$\begin{array}{l}\text { The Americans with Disabilities Act (ADA) provides specific guidelines and requirements that must be met in terms of accessibility. } \\
\text { However, in the case of unpaved trails, the requirements are less defined. An ADA trail must be firm, stable and slip resistant. } \\
\text { Some compacted aggregate material may meet this definition, but degrade over time and can no longer be ADA compliant. The } \\
\text { benefits of using unpaved surfaces for ADA trails include fit to the natural environment, cost, sustainability and environmental } \\
\text { benefits such as increased permeability. If an unpaved surface can be improved with the use of an additive, more could be used } \\
\text { as ADA accessible trails. Naturally occurring, volcanic ash from the eruption of Mt. Mazama is a natural pozzolan. This study } \\
\text { examined using this natural pozzolan, in addition to other materials, as a naturally occurring binder. This binder was applied to } \\
\text { existing and newly created compacted aggregate trails in the laboratory and the field to determine the benefit as a stabilizer. ADA } \\
\text { accessibility tools such as the rotational penetrometer were used to determine if the surface is improved to a firm and stable } \\
\text { surface. By determining a low-cost, sustainable solution for improvement of ADA accessible trails, more people will have access } \\
\text { and connectivity will increase in our community. This study outlines the long-term benefits of using naturally occurring, volcanic } \\
\text { ash as a binder applied topically to unpaved trails and discusses the expected increases to firmness and stability. }\end{array}$} \\
\hline 17. Key Words & & $\begin{array}{l}\text { 18. Distri } \\
\text { No res } \\
\text { www.n }\end{array}$ & $\begin{array}{l}\text { tatement } \\
\text { Copies av } \\
\text { et }\end{array}$ & \\
\hline $\begin{array}{l}\text { 19. Security Classification (of this report) } \\
\text { Unclassified }\end{array}$ & $\begin{array}{l}\text { 20. Security Classification (of this } \\
\text { page) } \\
\text { Unclassified }\end{array}$ & & of Pages & 22. Price \\
\hline
\end{tabular}




\section{ACKNOWLEDGEMENTS}

Matthew Sleep would like to acknowledge support from the National Institute for Transportation and Communities (NITC) under grant number (1131).

Cover photo by Matthew Sleep.

\section{DISCLAIMER}

The contents of this report reflect the views of the authors, who are solely responsible for the facts and the accuracy of the material and information presented herein. This document is disseminated under the sponsorship of the U.S. Department of Transportation University Transportation Centers Program in the interest of information exchange. The U.S. Government assumes no liability for the contents or use thereof. The contents do not necessarily reflect the official views of the U.S. Government This report does not constitute a standard, specification, or regulation.

\section{RECOMMENDED CITATION}

Sleep, Matthew and Matzen, Damian. ADA Accessible Trail Improvement with Naturally Occurring, Sustainable Materials. NITC-RR-1131. Portland, OR:

Transportation Research and Education Center (TREC), 2019. 
TABLE OF CONTENTS

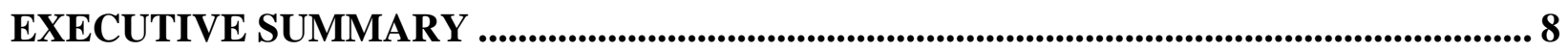

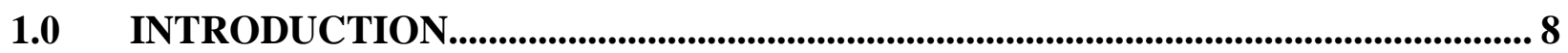

2.0 BACKGROUND …................................................................................................. 10

2.1 ADA ACCESSIBLE TRAILS ................................................................................. 10

2.2 OYSTER SHELLS AS SUPPLMENTARY CEMENTITIOUS MATERIALS ............... 12

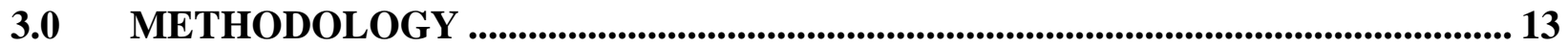

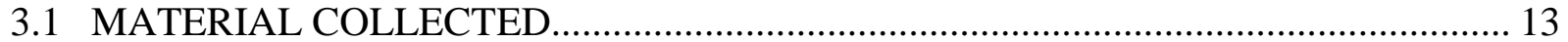

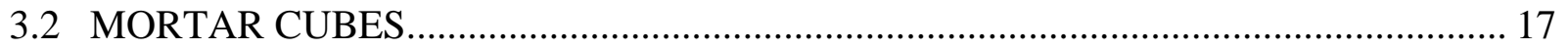

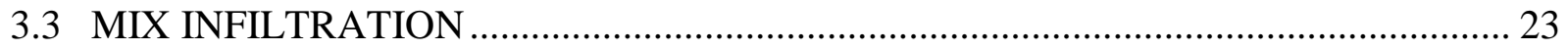

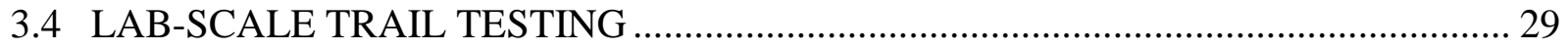

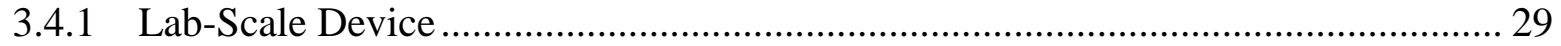

3.4.2 Effects of Compaction and Confinement............................................................. 31

3.4.3 Treatment of Lab-Scale Surfaces........................................................................ 33

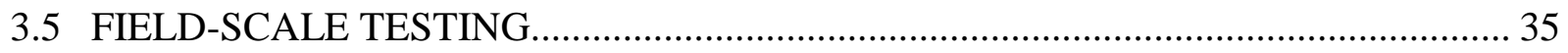

4.0 DATA INTERPRETATION AND CORRELATIONS.................................................47

4.1.1 Compressive Strength and Ratio of Volcanic Ash to Portland Cement .................... 47

4.1.2 Firmness and Stability............................................................................................... 53

4.1.3 Correlations between Pour Tests and Gravel Gradations ........................................ 55

4.1.4 All Correlations of Data Collected ........................................................................... 56

5.0 CONCLUSIONS ........................................................................................................... 58

6.0 REFERENCES.................................................................................................. 59

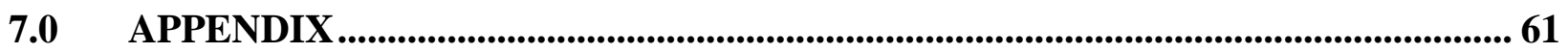

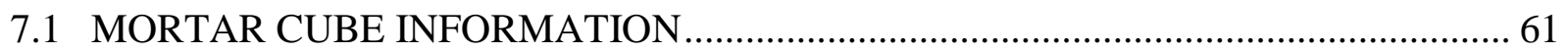

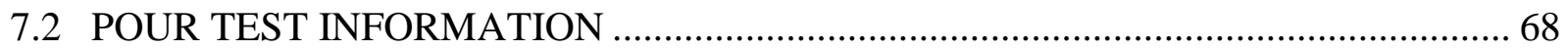

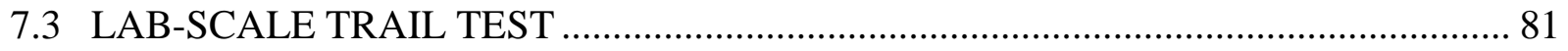

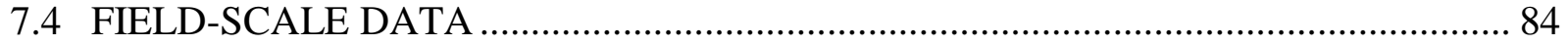

7.5 COMMERCIAL STABILIZER DATA SHEETS........................................................ 101

\section{LIST OF FIGURES}

Figure 1 - BDRP indenter being lowered onto the surface to measure readings .......................... 12 Figure 4 - Location of volcanic ash collection, limits from Walker, 1951 .................................... 14 Figure 5 - Rock crusher used to process volcanic ash as part of this study (kandmkruchers.com)

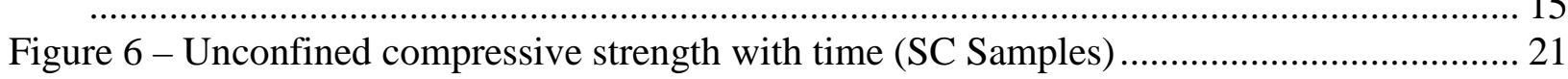

Figure 7 - Unconfined compressive strength of all mortar cubes (excluding control SC group) 22 Figure 8 - Depth of infiltration with different levels of volcanic ash processing during initial

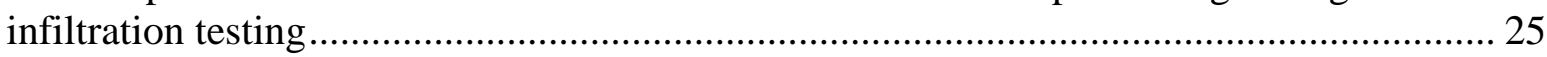

Figure 9 - Percentage of material bound with different levels of volcanic ash processing during initial infiltration testing .................................................................................................. 25

Figure 10 - Depth of infiltration compared against percentage of bound material for a 1.5 volcanic ash ratio, separated by mixture water content ........................................................ 26

Figure 11 - Percentage of bound material for recreated geotrail infiltration tests ......................... 27 
Figure 12 - Infiltration depth for recreated geotrail infiltration tests...................................... 27

Figure 13 - Results for SoilTac stabilizer infiltration tests plotted opposite each other.............. 28 Figure 14 - Lab-scale trail testing device (red outline showing pin locations to move the walls to

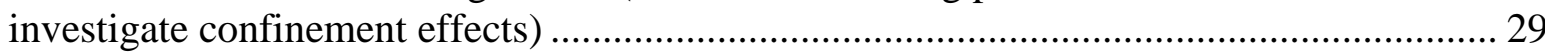

Figure 15 - Two gradations of gravel used in the lab-scale testing device .............................. 31

Figure 16 - Firmness and stability for gravel in lab-scale firmness and stability testing that was compacted by a vibratory compactor (material C1) ................................................... 32

Figure 17 - Firmness and stability for gravel in lab-scale firmness and stability testing that was not compacted by a vibratory compactor (material C1) ................................................. 32

Figure 18 - Weight of cementitious mix applied plotted against the change in firmness and stability after treatment during lab-scale firmness and stability testing ........................... 34

Figure 19 - Application of materials at the field site.......................................................... 35

Figure 20 - Proportional change in surface characteristics for lots 11, 12, and 1 over 10 weeks of field-scale testing $-70 \%$ water mixes .................................................................. 37

Figure 21 - Proportional change in surface characteristics for lots 8, 9, and 10 over 10 weeks of

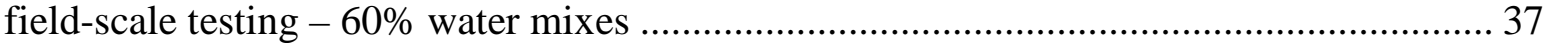

Figure 22 - Proportional change in surface characteristics for lots 7, 3, and 2 over 10 weeks of

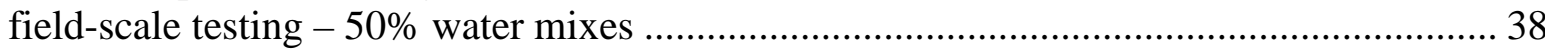

Figure 23 - Proportional change in surface characteristics for lots 4, 5, and 6 over 10 weeks of field-scale testing - commercial stabilizers ............................................................. 38

Figure 24 - Firmness of lots 1, 12, and 11 with time during field-scale firmness and stability testing.

Figure 25 - Firmness of lots 10, 9, and 8 with time during field-scale firmness and stability testing.....

Figure 26 - Firmness of lots 2, 3, and 7 with time during field-scale firmness and stability testing

Figure 27 - Firmness of lots 4, 5, and 6 with time during field-scale firmness and stability testing

Figure 28 - Stability of lots 1, 12, and 11 with time during field-scale firmness and stability testing..... 44

Figure 29 - Stability of lots 10, 9, and 8 with time during field-scale firmness and stability testing 45

Figure 30 - Stability of lots 2, 3, and 7 with time during field-scale firmness and stability testing 45

Figure 31 - Stability of lots 4, 5, and 6 with time during field-scale firmness and stability testing.

Figure 32 - The comparison between the compressive strength for each testing time period compared to the ratio of volcanic ash to portland cement ............................................ 48

Figure 33 - Compressive strength and ratio of volcanic ash to portland cement (seven-day cure

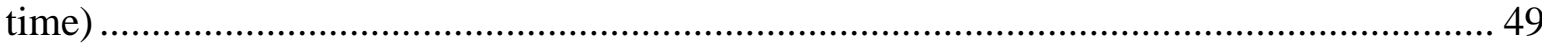

Figure 34 - Compressive strength and ratio of volcanic ash to portland cement (21-day cure

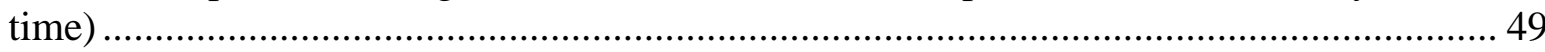

Figure 35 - Compressive strength and ratio of volcanic ash to portland cement (28-day cure

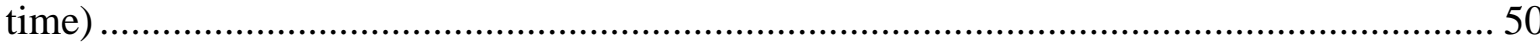

Figure 36 - Compressive strength and ratio of volcanic ash to portland cement (42day cure time) 
Figure 37 - Compressive strength and ratio of volcanic ash to portland cement (56-day cure time)

Figure 38 - Compressive strength and ratio of volcanic ash to portland cement (70-day cure time)

Figure 39 - Compressive strength and ratio of volcanic ash to portland cement (84-day cure time)

Figure 38 - Comparison of unconfined compressive strength for mortar cubes made with increasing replacement of portland cement with volcanic ash - 1, 2, 4, and 7 week curing times 52

Figure 40 - Measured values of firmness and stability with the BDRP as part of this study....... 53

Figure 41 - Linear regression of firmness and stability for all treated surfaces........................ 54

Figure 42 - Linear regression of firmness and stability for all untreated surfaces ..................... 55 Figure 43 - Results of pour tests for percentage bound material correlated to $\mathrm{D}_{10}$ of the gravel (ash/cement ratio 1.5).

Figure 44 - Results of pour tests for infiltration depth correlated to $\mathrm{D}_{10}$ of the gravel (ash/cement

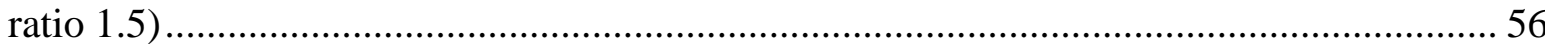

Figure 45 - Unconfined compressive strength with time (LC Samples) .................................63

Figure 46 - Unconfined compressive strength with time (OC Samples) ................................. 64

Figure 47 - Unconfined compressive strength with time (LPC Samples)................................ 65

Figure 48 - Unconfined compressive strength with time (OPC Samples) ...............................66

Figure 49 - Unconfined compressive strength with time (RC Samples)................................67

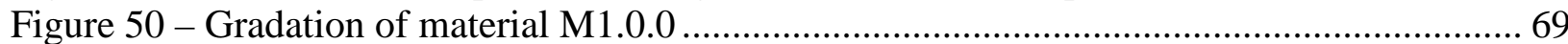

Figure 51 - Gradation of material M1.1.0 ................................................................. 69

Figure 52 - Gradation of material M1.1.1 …............................................................ 70

Figure 53 - Gradation of material M2.0.0 - upper $(6.6 \mathrm{~cm})$ and lower $(13.4 \mathrm{~cm})$ layers ............. 71

Figure 54 - Gradation of material 2.0.1 upper $(6.6 \mathrm{~cm})$ and lower $(13.4 \mathrm{~cm})$ layers ................. 72

Figure 55 - Gradation of material M 3.0.0 upper $(6.6 \mathrm{~cm})$ and lower $(13.4 \mathrm{~cm})$ layers ............ 73

Figure 56 - Gradation of material M 3.0.1 upper $(6.6 \mathrm{~cm})$ and lower $(13.4 \mathrm{~cm})$ layers ............. 74

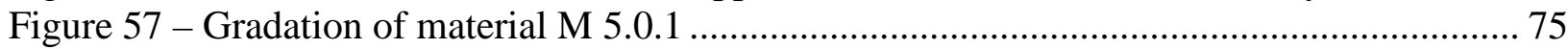

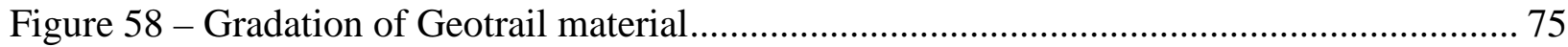

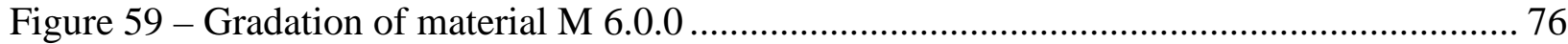

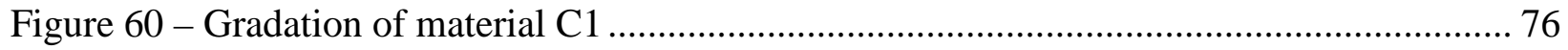

\section{LIST OF TABLES}

Table 1. Recommended firmness and stability measurements for ADA accessible surfaces using

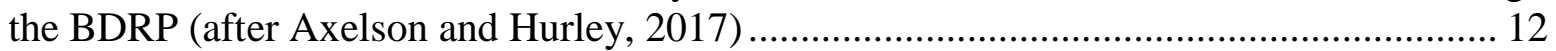

Table 2. Chemical requirements for ASTM C-618 pozzolan classifications .............................. 16

Table 3. Physical requirements for ASTM C-618 pozzolan classifications .............................. 16

Table 4. Chemical analysis of volcanic ash collected for this study ...................................... 16

Table 5. Wash No. 325 results after passing volcanic ash through the rock crusher................... 16

Table 6. Mortar cubes created and tested for unconfined strength as part of this study (after Sleep

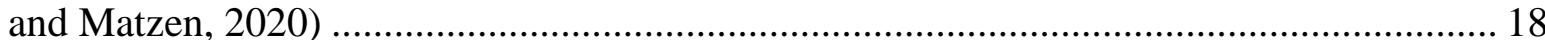

Table 7. Mortar cube mix designs for compressive strength ................................................. 19

Table 8. Unconfined strength of mortar cubes following the ASTM C311 procedure replacing portland cement with processed volcanic ash ....................................................... 21 
Table 9. Correlation coefficients of all mortar cube data from 7-84 days and from 42-84 days (excluding control SC group)........................................................................................... 22

Table 10. Infiltration test materials with descriptions and applied cementitious mixes................ 24

Table 11. Results of cementitious mixes on recreated geotrail samples during infiltration testing 28

Table 12. Change in firmness and stability (percentage increase) between compacted and uncompacted specimens $\mathrm{C} 1$ in the lab-scale trail testing device .......................................... 32

Table 13. Lab-scale firmness and stability testing samples and cementitious mixes by weight .. 33

Table 14. Effects of topically applied cementitious mixes during lab-scale firmness and stability testing. 34

Table 15. Information regarding the 12 sections used during field-scale firmness and stability

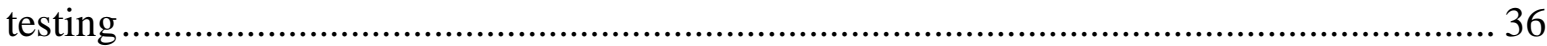

Table 16. Count of firmness and stability results that showed beneficial change or non-beneficial change during field-scale firmness and stability testing ........................................................ 39

Table 17. Relative change in surface firmness and stability, averaged over 10 weeks ................. 39

Table 18. Variation in surface firmness during field-scale firmness and stability testing per week

Table 19. Variation in surface stability during field-scale firmness and stability testing per week

Table $20 . \ldots$.

Table 21. Compressive strength of mortar cubes with increasing ratios of volcanic ash to portland cement (strength in psi) ....................................................................................... 47

Table 22. Comparison of chemical composition and fineness between Mt. Mazama volcanic ash and that studied by Hossain and Lachemi (2006) ................................................................. 48

Table 23. Data collected and linear regression interpretation for this project ................................ 57

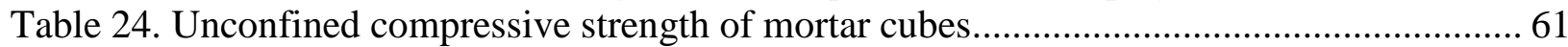

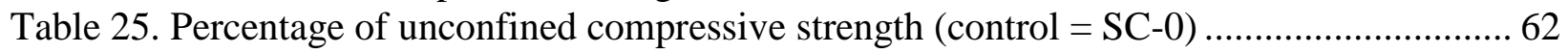

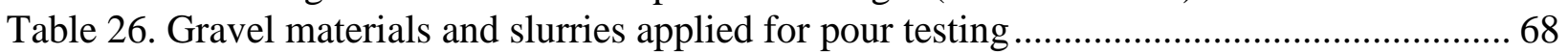

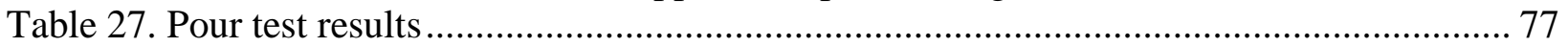

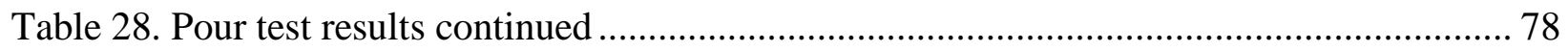

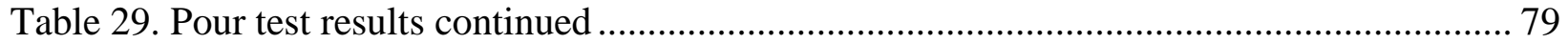

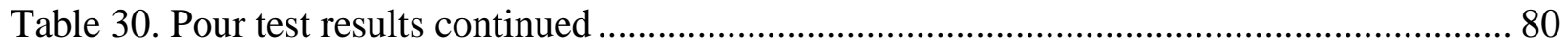




\section{EXECUTIVE SUMMARY}

An extensive lab and field program has been conducted to determine if topically applied binder of portland cement and volcanic ash can increase the firmness and stability of unpaved trails to meet ADA requirements. Mortar cubes (175) were created to determine the long-term effect of replacing portland cement with volcanic ash, a previously researched natural pozzolan, on unconfined compressive strength. Volcanic ash provides a beneficial long-term gain in strength when used with portland cement. Mix infiltration tests (185) were conducted using compacted gravel samples, and varying proportions of water, portland cement and volcanic ash. Samples with $60 \%$ water appear to bind more material than $50 \%$ or $70 \%$ water. There is no clear correlation between gravel gradational properties and infiltration of portland cement, volcanic ash and water slurries. A lab-scale trail testing device was constructed with adjustable confinement to determine the method of topical slurry application. It was determined that confinement and compaction have little effect on firmness and stability. Twelve separate trail lots were constructed in the field on the Oregon Institute of Technology campus. These lots were all treated with different proportioned mixes of portland cement, volcanic ash and water. In addition, three commercially available gravel stabilizers were used. It was observed that over 70 days of monitoring, the lots treated with portland cement and volcanic ash continued to show improvement at a higher rate than the commercial stabilizer. The commercial stabilizers had higher improvements to stability, but a negative impact on firmness.

\subsection{INTRODUCTION}

This report is a continuation of work started with NITC-RR-1075, The Use of Mt. Mazama Volcanic Ash as Natural Pozzolans for Sustainable Soil and Unpaved Road Improvement by Sleep and Masley (2018). In that report, it was concluded that volcanic ash from the eruption of Mt. Mazama, which is prevalent across the Pacific Northwest and, in particular, Southern Oregon, could be used as a natural pozzolan and replacement for portland cement. It was also shown in the Sleep and Masley report that any replacement of portland cement with processed, volcanic ash reduced both embodied energy and carbon dioxide emissions.

With the knowledge that Mt. Mazama volcanic ash is a sustainable, naturally occurring pozzolan, an innovative use of the material has been researched as part of this report. The ADA Accessibility Guidelines (ADAAG) Section 4.5 and Architectural Barriers Act (ABA) Standards (2015) requires that for accessibility, ground and floor surfaces be firm and stable (DOJ, 2015). The Department of Defense (DOD), General Services Administration (GSA) and the U.S. Postal Service (USPS) have adopted the ABA Standards. In addition, many states such as California have adopted these standards for trails. Trails as defined by the ABA include, "a pedestrian route developed primarily for outdoor recreational purposes. Pedestrian routes that are developed 
primarily to connect accessible elements, spaces, and buildings within a site are not a trail.” The ABA guidelines apply to all new and modified trails for outdoor areas developed by the federal government. Many states and municipalities have adopted these standards. According to the United States Access Board, “The Board intends to develop guidelines for non-federal outdoor sites covered by the Americans with Disabilities Act (ADA) and areas developed with federal grants and loans covered by the ABA through a subsequent rulemaking (acess-board.gov).” Thus, more recreational areas and trails will be subject to these requirements in the future. Four conditions for exceptions are included in these standards:

1. Compliance is not practicable due to terrain. The phrase "not practicable" means not reasonably doable.

2. Compliance cannot be accomplished with the prevailing construction practices.

3. Compliance would fundamentally alter the function or purpose of the facility or the setting.

4. Compliance is limited or precluded by any of the following laws, or by decisions or opinions issued or agreements executed pursuant to any of the following laws:

a. Endangered Species Act (16 U.S.C. $\S \S 1531$ et seq.)

b. National Environmental Policy Act (42 U.S.C. §§ 4321 et seq.)

c. National Historic Preservation Act (16 U.S.C. $\S \S 470$ et seq.)

d. Wilderness Act (16 U.S.C. §§ 1131 et seq.)

e. Other federal, state or local law, the purpose of which is to preserve threatened or endangered species; the environment; or archaeological, cultural, historical, or other significant natural features

These guidelines have gradually been adopted as standard practice. The ABA (2015) standards include both scoping requirements and technical requirements. Trail requirements were first introduced to the ABA standards in 2010.

In addition to technical requirements such as width and slope, the trail surface must be described as firm and stable. A description of this is provided in Section 2.1. This report details an extensive laboratory and field program to determine if unpaved trail surfaces can be improved with the use of Mt. Mazama volcanic ash applied topically to unpaved surfaces.

To accomplish this goal, four separate programs were implemented. First, 175 mortar cubes were created to determine the effects of replacing portland cement with volcanic ash on unconfined compressive strength. In addition to portland cement, other naturally occurring sources of calcium oxide were used. In addition to creating strong cemented materials, it was recognized that the ability of topically applied materials to penetrate and bind the most amount of material would be beneficial. During the second portion of lab testing, innovative pour tests were completed. In all, 185 gravel pour samples were created. During the third portion of lab testing, artificial trails were created in the lab. Two devices were constructed. These devices allowed for a full size (width) trail to be created in the lab. The walls of the trail device were movable to determine the effects of confinement. Forty-three separate combinations of gravel and binders were created and placed in the lab-scale trail testing device. The firmness and stability of these treated surfaces were examined with the Beneficial Designs rotational penetrometer (BDRP). Based on the results of these three separate lab tests, 12 separate lots 
were created in the field on the Oregon Institute of Technology campus. These 12 lots along an existing trail were all treated with different topically applied binding materials. The firmness and stability of these lots were also tested with the BDRP. Monitoring of the field implemented trail lots has been occurring for approximately 180 days.

\subsection{BACKGROUND}

A literature review on the natural pozzolan process and soil stabilization is presented in Sleep and Masley (2018).

\subsection{ADA ACCESSIBLE TRAILS}

Several organizations have produced dimension guidance for outdoor trails, including running slopes, cross slopes, trail widths, flat resting areas, and distances between those resting areas. Every design guide states that clear tread widths should 36in $(915 \mathrm{~mm})$, unless required to reduce down to 32in (815mm) due to external factors. If a width smaller than 32in (815mm) is required, the trail must be as wide as possible. Tennessee and California departments do not mention going smaller than the exception, but they do not expressly forbid it, either (Richards, 2007; California, 2009). It appears that these dimensional guidelines originate from the Americans with

Disabilities Act, Section 403.5.1, which clarifies that the reduced width of 32in (815mm) cannot exceed 24in $(610 \mathrm{~mm})$ in length.

Slopes and cross slopes are also similar between different guidelines. Guidance for cross slope of trails dictates a maximum of 5\%. Some places allow for a more drastic cross slope for the purposes of drainage, but for limited distances (Richards, 2007). The U.S. Department of Agriculture states that cross slope can be variable, but should not exceed the aforementioned 5\%, unless the surface of the trail is paved or constructed with boards. In this instance, as the surface is more controllable, the slope should not exceed 2\% (Zeller, 2012). This stipulation is corroborated by the U.S. Forest Service Forest Service Trail Accessibility Guidelines (FSTAG) (U.S. Forest Service, 2013).

Running slopes are preferred at 5\% or lower, with steeper slopes being allowed for increasingly shorter distances. Steeper slopes require flat stretches of trail with a minimum length of 60in $(1.52 \mathrm{~m})$. Slopes of $10 \%$ are restricted to lengths of $30 \mathrm{ft}(9.1 \mathrm{~m})$, and $12 \%$ is restricted to $10 \mathrm{ft}$ (3m). FSTAG and others allow for a slope between $5 \%$ and $8 \%$ for an extent of $200 \mathrm{ft}(61 \mathrm{~m})$ (U.S. Forest Service, 2013).

Moore Inacofano Goltsmann, Inc (MIG) have included, in their guidelines, specifications for multiuse trails. These trails are wider and intended for bicyclists and equestrians in addition to normal hikers, while maintaining the requirement that a surface must be firm and stable. Recommended trail widths increase to a range of $8 \mathrm{ft}$ to $10 \mathrm{ft}(2.5 \mathrm{~m}$ to $3 \mathrm{~m})$ with a corridor of $12 \mathrm{ft}$ to $14 \mathrm{ft}(3.6 \mathrm{~m}$ to $4.2 \mathrm{~m})$. This corridor is spacing that should be cleared of vegetation (MIG, 2006). 
Every design guideline declared the trail surface must be firm and stable, but did not provide exact guidance as to what that meant. The U.S. Department of Justice released the Americans with Disabilities Act (ADA) in 1990 with the intention of removing and preventing discrimination or exclusion of American citizens with disabilities. This was updated in 2010. Under the ADA, it is stated that "floor and ground surfaces shall be stable, firm, and slip resistant.” The only guidance for these terms is that stable surfaces must return to their original state after a load is applied and then removed, and firm surfaces must resist deformation. For standard urban materials and design practices, these criteria are typically met with ease. However, there are no numerical guidelines to aid in the design of compliant outdoor surfaces, or surfaces that require impact attenuation.

ASTM F1951 was designed in order to allow for direct guidance and a clear answer as to whether a surface qualifies as firm and stable for playground surfaces. Playground surfaces, due to the nature of having children falling on them, must allow for some deformation to reduce or prevent injuries while still allowing all children to enjoy the playground. A surface that is too flexible would prohibit the use by children with conditions that impair movement, but a surface that is not flexible could lead to severe injuries should a child fall. The procedure of ASTM F1951 is to create a stretch of the intended playground surface and then compare the resistance and effort required to push a wheelchair across the surface to that of pushing a wheelchair up a $1: 14$ (7\%) slope. It should be noted that this slope is steeper than the running slope recommended in ADA of 1:20 (5\%).

Testing according to ASTM F1951 is not portable due to the necessity of the 1:14 ramp. To allow for field testing, Beneficial Designs created their rotational penetrometer (BDRP). The BDRP is a device designed to determine the firmness and stability by simulating a weighted wheelchair wheel and measure deformation from static loading onto the surface and then after the wheel has been moved across the surface a set number of times. Firmness testing is defined as the deformation of the surface by vertical loading of the BDRP tire after removing any potential sources of friction or resistance in the device system and resetting the measurement reference to the surface of interest. Stability testing occurs after firmness testing. Without resetting the BDRP, the loading wheel is rotated 90 degrees counter clockwise and then clockwise. This is repeated until the wheel has made a total of four motions, and then readings are taken. Readings are taken from a component on the BDRP that measures the vertical travel of the attached wheel. Firmness and stability values are calculated by removing the highest and lowest recorded values for a surface and averaging the rest. Five readings are taken per material due to the size of the frame, which is the lowest recommended by Beneficial Designs. These instructions are outlined in the BDRP 100 Series Manual and illustrated by Figure 1, and (Beneficial Designs, 2014).

For a surface to be declared "firm," the deflections measured by the BDRP must be under 0.3in $(7.62 \mathrm{~mm})$. If the deflection is above $0.3 \mathrm{in}(7.62 \mathrm{~mm})$, but below $0.5 \mathrm{in}(12.7 \mathrm{~mm})$, the surface is declared "moderately firm." A firmness value above $0.5 \mathrm{in}(12.7 \mathrm{~mm})$ and the surface is determined to be "not firm." The same is true for stability, as well, with the boundaries being $0.5 \mathrm{in}(12.7 \mathrm{~mm})$ and $1.0 \mathrm{in}(25.4 \mathrm{~mm})$ in place of the 0.3 in and $0.5 \mathrm{in}$ values, respectively. Surfaces are declared as neither firm nor stable if the combined firmness and stability readings are above 1.5in (38.1mm) (Axelson and Hurley, 2017). 
Table 1. Recommended firmness and stability measurements for ADA accessible surfaces using the BDRP (after Axelson and Hurley, 2017)

\begin{tabular}{|c|c|}
\hline \multicolumn{2}{|c|}{ Firmness } \\
\hline & Penetration Depth (mm) \\
\hline Firm & $<0.3$ \\
\hline Moderately Firm & 0.3 to 0.5 \\
\hline Not Firm & $>0.5$ \\
\hline \multicolumn{2}{|c|}{ Stability } \\
\hline \multicolumn{2}{|c|}{ Penetration Depth (mm) } \\
\hline Stable & $<12.7$ \\
\hline Moderately Stable & 12.7 to 25.4 \\
\hline Not Stable & $>25.4$ \\
\hline
\end{tabular}

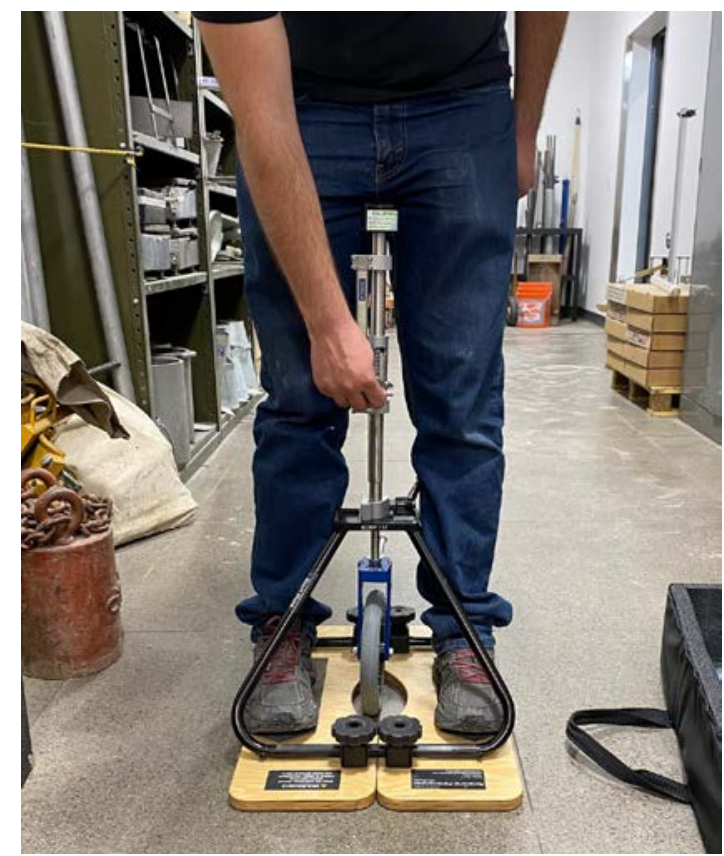

Figure 1 - BDRP indenter being lowered onto the surface to measure readings

\subsection{OYSTER SHELLS AS SUPPLMENTARY CEMENTITIOUS MATERIALS}

As part of this study, a locally available, natural material was used to supply necessary calcium to the mix design. This material was crushed and processed oyster shells. As a primary goal of this work was a focus on sustainable design, a material such as oyster shells, can provide the necessary calcium for a cementitious reaction in a sustainable manner. On their own, oyster shells do not contain cementitious materials and must be combined with an additional pozzolan, such as volcanic ash, to create cement (Papadakis and Tsimas 2002). 
A study was conducted by Liang and Wang (2013) and the use of oyster shells and fly ash to create a cementitious material that could be used to increase the strength of compacted soil. They concluded and oyster shells and fly ash do not create a significant pozzolanic reaction when mixed with soil. A limitation of their study includes that the oyster shells were crushed, but not processed. In a natural form, oyster shells contain calcium in the form of $\mathrm{CaCO}_{3}$. Therefore, the shells must be heated to removed $\mathrm{CO}_{2}$ and create $\mathrm{CaO}$ necessary for pozzolanic reactivity.

Seo et al. (2019) investigated the use of calcined and crushed oyster shells for cement mortars. Prior to use, the oyster shells were processed with heat to remove $\mathrm{CO}_{2}$ and increase the $\mathrm{CaO}$ content of the material. The study indicated that replacements of up to $3 \%$ calcined oysters shells had a significant positive effect on compressive strength of mortar cubes. Therefore this study proceeded using calcined oyster shells.

\subsection{METHODOLOGY}

\subsection{MATERIAL COLLECTED}

The materials used in this study were described in Sleep and Masley (2018). In that study, volcanic ash from the eruption from Mt. Mazama in Southern Oregon was collected and studied for use as a natural pozzolan in portland cement concrete. These collected materials are described here again with updated properties investigated as part of this study.

According to the USGS (2002), Mt. Mazama erupted approximately 7,700 years ago. The eruption caused the volcano to collapse, forming what is now known as Crater Lake. Similar to the Mt. St. Helens eruption in 1980, the eruption of Mt. Mazama blanketed the Pacific Northwest with volcanic ash and pumice. Sleep and Masely located deposits of volcanic ash located near the Oregon Institute of Technology campus. These deposits were characterized as "ash fall" deposits. Ash fall deposits are desirable for use as a natural pozzolan compared to welded ash or pumice, as less processing is necessary prior to use in portland cement concrete.

Figure 2 shows the location where material was collected as part of this study. This is the same location as Sleep and Masley. Volcanic ash from the eruption of Mt. Mazama is found at the ground surface in this location and is unwelded. Therefore, collection requires minimal effort. As shown in Figure 2, Walker (1951) mapped airfall deposits of volcanic ash in this location. 


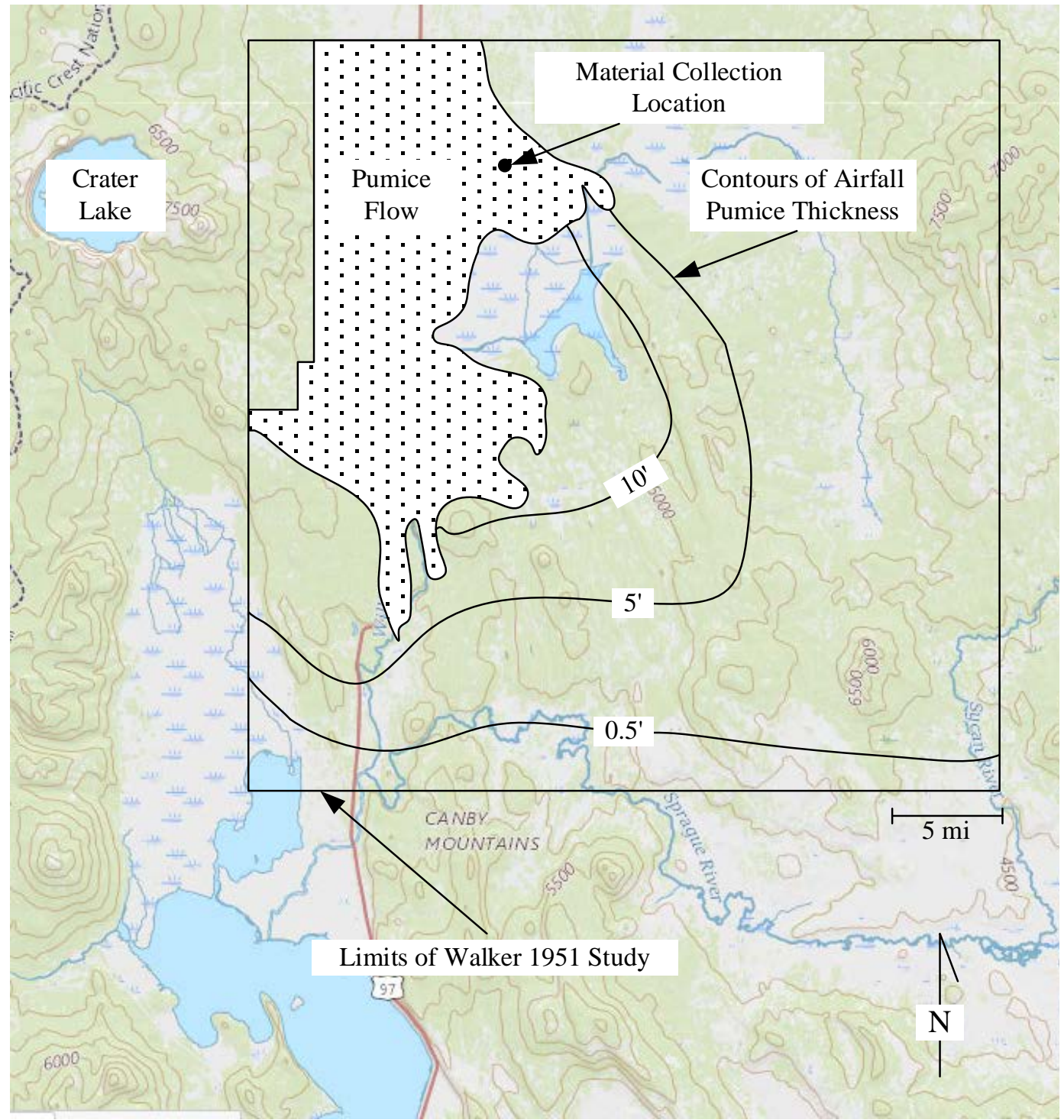

Figure 2 - Location of volcanic ash collection, limits from Walker, 1951

The Sleep and Masley study showed that the volcanic ash from this location met few of the physical and chemical requirements of a Class N pozzolan, as shown in Table 2 and Table 3. Several samples of the volcanic ash were sent to a materials testing laboratory to determine the chemical composition. The results of those tests are shown in Table 4 . The volcanic ash meets all chemical requirements of Class $\mathrm{N}, \mathrm{F}$ or $\mathrm{C}$ pozzolans.

The physical requirements for a natural pozzolan investigated as part of this study include the fineness and strength activity index. Water requirements, autoclave expansion and density variation were not studied. As noted in the Sleep and Masley study, the volcanic ash material did not meet fineness or strength activity index requirements in an unprocessed, natural state. The fineness of the material is determined by the amount of material retained on a wash No. 325 sieve (ASTM C430-17). Sleep and Masley recommended a program to determine how to process the volcanic ash into a fine material. In the Sleep and Masley study, the material was crushed with a mortar and pestle and then passed through the No. 200 sieve prior to being used 
as a natural pozzolan. This method produced adequate results in terms of strength activity index. For this study, a method was needed to produce larger quantities of processed volcanic ash. To accomplish this, a gas-powered rock crusher typically used for the gold mining industry was used. This crusher spins carbide chains at high speed to create sub No. 200 size material. The unit, shown in Figure 3, was able to process 25 gallons (300 lbs) of volcanic ash material in less than one hour.

To meet fineness requirements, a maximum of $34 \%$ of the material can be retained on a wash No. 325 sieve. Prior to processing, samples of volcanic ash averaged $83 \%$ retained on the wash No. 325 sieve. As shown in Table 5, after processing the material, the average retained on the wash No. 325 sieve is $42 \%$. While this is slightly higher than the required $34 \%$ according to the ASTM, the process shows that achieving a finer material with minimal effort is possible. As with the Sleep and Masley study, the material was then passed through the No. 200 sieve before being used as a pozzolan.

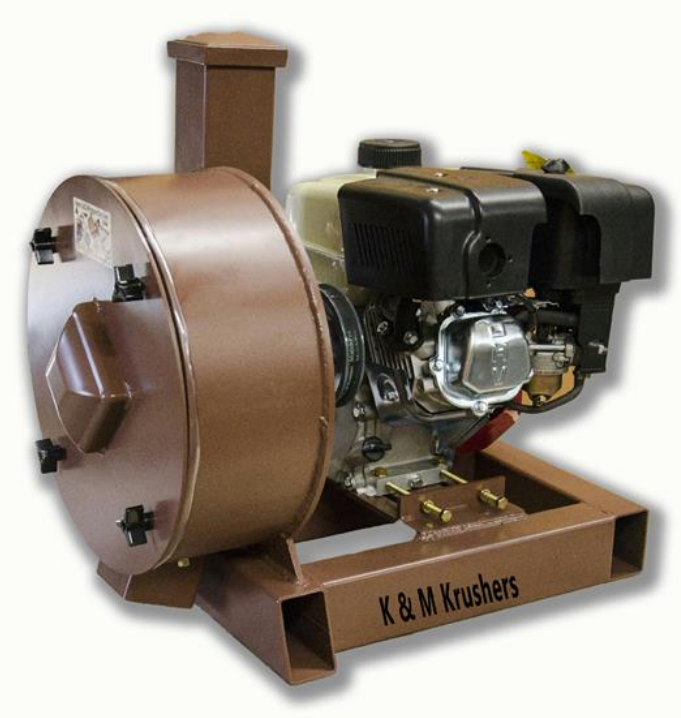

Figure 3 - Rock crusher used to process volcanic ash as part of this study (kandmkruchers.com) 
Table 2. Chemical requirements for ASTM C-618 pozzolan classifications

\begin{tabular}{|l|c|c|c|}
\hline \multicolumn{3}{|c|}{ Chemical Requirements } \\
\hline \multicolumn{1}{|c|}{ Component } & Class \\
\hline $\mathrm{SiO}_{2}+\mathrm{Al}_{2} \mathrm{O}_{3}+\mathrm{Fe}_{2} \mathrm{O}_{3}$ min, \% & $\mathrm{N}$ & $\mathrm{F}$ & $\mathrm{C}$ \\
\hline $\mathrm{SO}_{3}$, max \% & 70.0 & 70.0 & 50.0 \\
\hline Moisture content, max \% & 4.0 & 5.0 & 5.0 \\
\hline Loss on ignition, max \% & 3.0 & 3.0 & 3.0 \\
\hline
\end{tabular}

Table 3. Physical requirements for ASTM C-618 pozzolan classifications

\begin{tabular}{|l|c|c|c|}
\hline \multicolumn{4}{|c|}{ Physical Requirements } \\
\hline \multicolumn{1}{|c|}{ Requirement } & Class \\
\hline \multicolumn{1}{|c|}{ Fineness (retained on No. 325 sieve), max \% } & 34 & F & C \\
\hline $\begin{array}{l}\text { Strength activity index seven days, \% of } \\
\text { control }\end{array}$ & 75 & 75 & 75 \\
\hline Strength activity index 28 days, \% of control & 75 & 75 & 75 \\
\hline Water requirement max \% of control & 115 & 105 & 105 \\
\hline Autoclave expansion or contraction, max \% & 0.8 & 0.8 & 0.8 \\
\hline Max density variation from average, \% & 5 & 5 & 5 \\
\hline
\end{tabular}

Table 4. Chemical analysis of volcanic ash collected for this study

\begin{tabular}{|l|c|c|c|c|c|c|}
\hline Compound (\%) & Sample_AA_\#1 & Sample_AA_\#2 & Sample_BB_\#1 & Sample_BB_\#2 & Sample_CC_\#1 & Sample_CC_\#2 \\
\hline $\mathrm{SiO}_{2}$ & 68.0 & 67.7 & 65.5 & 65.2 & 64.2 & 64.2 \\
\hline $\mathrm{Al}_{2} \mathrm{O}_{3}$ & 18.1 & 18.0 & 19.2 & 19.2 & 19.0 & 19.1 \\
\hline $\mathrm{Fe}_{2} \mathrm{O}_{3}$ & 4.0 & 4.0 & 4.5 & 4.5 & 4.7 & 4.8 \\
\hline $\mathrm{CaO}$ & 2.8 & 2.9 & 3.5 & 3.4 & 4.0 & 4.0 \\
\hline $\mathrm{MgO}$ & 1.2 & 1.2 & 1.5 & 1.4 & 1.8 & 1.8 \\
\hline $\mathrm{SO}_{3}$ & 0.0 & 0.0 & 0.0 & 0.0 & 0.0 & -0.1 \\
\hline $\mathrm{Na}_{2} \mathrm{O}$ & 3.3 & 3.3 & 3.1 & 3.1 & 3.2 & 3.2 \\
\hline $\mathrm{K}_{2} \mathrm{O}$ & 2.3 & 2.3 & 2.0 & 2.0 & 1.7 & 1.7 \\
\hline $\mathrm{TiO}_{2}$ & 0.6 & 0.6 & 0.6 & 0.6 & 0.7 & 0.7 \\
\hline $\mathrm{P}_{2} \mathrm{O}_{5}$ & 0.1 & 0.1 & 0.1 & 0.1 & 0.1 & 0.1 \\
\hline $\mathrm{Mn}_{2} \mathrm{O}_{3}$ & 0.1 & 0.1 & 0.1 & 0.1 & 0.1 & 0.1 \\
\hline Loss On Ignition & 2.1 & 2.1 & 1.9 & 2.0 & 2.0 & 2.2 \\
\hline Total Alkali & 4.8 & 4.8 & 4.4 & 4.4 & 4.3 & 4.3 \\
\hline
\end{tabular}

Table 5. Wash No. 325 results after passing volcanic ash through the rock crusher

\begin{tabular}{|c|c|c|c|c|}
\hline Sample & $\begin{array}{c}\text { Original Dry Weight } \\
\text { (g) }\end{array}$ & $\begin{array}{c}\text { Retained Weight } \\
\text { on the Sieve (g) }\end{array}$ & $\begin{array}{c}\text { Weight Lost } \\
\text { through Sieve } \\
\text { (g) }\end{array}$ & $\begin{array}{c}\text { Percentage } \\
\text { Retained }\end{array}$ \\
\hline 1 & 1.01 & 0.44 & 0.57 & $44 \%$ \\
\hline 2 & 1.00 & 0.44 & 0.56 & $44 \%$ \\
\hline 3 & 1.01 & 0.4 & 0.61 & $40 \%$ \\
\hline
\end{tabular}




\subsection{MORTAR CUBES}

One stated goal of this research program is to determine the effects of replacing portland cement with a naturally occurring pozzolan on cured strength of a concrete. To accomplish this goal, a modified form of ASTM C311 was performed. ASTM C311 is the standard test method for sampling and testing natural pozzolans for use in portland cement concrete. One procedure in this standard is the strength activity index. To calculate this index requires the construction of ASTM Type 1 cubes out of mortar, water and graded sand, according to ASTM C150 specifications. The sand is a controlled mixture of grain sizes between standard U.S. sieve size \#30 and \#50. According to ASTM C311, 500g of cement mortar is to be used with $275 \mathrm{ml}$ of water and $1375 \mathrm{~g}$ of the graded sand to create six $5 \mathrm{~cm}$ cubes. Then $100 \mathrm{~g}$ of mortar is to be replaced with the additive of interest, in this case Mt. Mazama volcanic ash, and mixed with remaining $400 \mathrm{~g}$ of mortar, water, and sand to create six modified cubes of the same dimensions. Cubes were created with Mt. Mazama volcanic ash and tested for unconfined compressive strength.

Due to identified long-term strength of cement mixes with natural pozzolans (Bondar et al., 2011), the ASTMC311 was modified to include testing at 7, 28, 42, 56, 70, and 84 days.

Natural pozzolans are siliceous materials that poses no cementitious properties on their own, but will in the presence of calcium hydroxide form cementitious compounds (Mehta, 1987). The reaction of a natural pozzolan is described in Sleep and Masley (2018). As discussed in that report, the main compounds that react in a pozzolanic reaction are the calcium hydroxide $(\mathrm{Ca}(\mathrm{OH}) 2)$ from the hydration reaction and a silicic acid from the pozzolan. The silica glass ( $\mathrm{SiO} 2)$ in a natural pozzolan such as volcanic ash reacts with water to form a silicic acid. This reaction is demonstrated in Equation 1.

$\mathrm{SiO}_{2}+\mathrm{H}_{2} \mathrm{O} \rightarrow \mathrm{H}_{2} \mathrm{SiO}_{3}$

Equation 1.

One of the more common acids produced is orthosilicic acid (H4SiO4). The product of these reactions is a calcium silica hydrate (CSH), one possible reaction with these compounds is shown in Equation 2.

$\mathrm{Ca}(\mathrm{OH})_{2}+\mathrm{H}_{4} \mathrm{SiO}_{4} \rightarrow \mathrm{CaH}_{2} \mathrm{SiO}_{4} * 2 \mathrm{H}_{2} \mathrm{O}$

Equation 2.

In addition to portland cement supplying calcium hydroxide, it was investigated whether other sources of calcium hydroxide could be used to create cementitious products. For this study, crushed oyster shells and lime were used to supply calcium hydroxide.

Mortar cubes (175) were created to study the effects of replacing portland cement with various amounts of volcanic ash, lime and oyster shells. Due to the long-term strength gains common with pozzolans, unconfined compressive strength of the mortar cubes was tested at 7, 21, 28, 42, 56, 70 and 84 days. Six separate mix types were created, as shown in Table 6 and Table 7. Additional admixtures, such as plasticizers, were not used in the creation of mortar cubes. For 
each test sample (25), seven specimens were created to test at 7, 21, 28, 42, 56, 70 and 84 days for a total of 175 specimens.

Table 6. Mortar cubes created and tested for unconfined strength as part of this study (after Sleep and Matzen, 2020)

\begin{tabular}{|c|c|c|}
\hline Mix Designation & Mortar Mix & Alterations to Mortar Mix \\
\hline SC & $\begin{array}{l}\text { ASTM C109 Using 500g of } \\
\text { portland cement }\end{array}$ & $\begin{array}{l}\text { Replacement of portland } \\
\text { cement with 100, 150, } 200 \\
\text { and 300g of Mt. Mazama } \\
\text { volcanic ash }\end{array}$ \\
\hline $\mathrm{LC}$ & $\begin{array}{l}\text { ASTM C109 Using } \\
\text { equivalent volume of Type S } \\
\text { lime }\end{array}$ & $\begin{array}{l}\text { Replacement of Type S lime } \\
\text { with } 100,150 \text { and } 200 \mathrm{~g} \text { of } \\
\text { Mt. Mazama volcanic ash }\end{array}$ \\
\hline OC & $\begin{array}{l}\text { ASTM C109 Using } \\
\text { equivalent volume of crushed } \\
\text { oyster shells }\end{array}$ & $\begin{array}{l}\text { Replacement of oyster shells } \\
\text { with } 100,150 \text { and } 200 \mathrm{~g} \text { of } \\
\text { Mt. Mazama volcanic ash }\end{array}$ \\
\hline LPC & $\begin{array}{l}\text { ASTM C109 Using 100g of } \\
\text { portland cement and } \\
\text { equivalent volume of type S } \\
\text { lime }\end{array}$ & $\begin{array}{l}\text { Replacement of portland } \\
\text { cement and type S lime with } \\
100,150 \text { and } 200 \mathrm{~g} \text { of } \mathrm{Mt} \text {. } \\
\text { Mazama volcanic ash }\end{array}$ \\
\hline OPC & $\begin{array}{l}\text { ASTM C109 Using 100g of } \\
\text { portland cement and } \\
\text { equivalent volume of crush } \\
\text { oyster shells }\end{array}$ & $\begin{array}{l}\text { Replacement of portland } \\
\text { cement and oyster shells with } \\
100,150 \text { and } 200 \mathrm{~g} \text { of } \mathrm{Mt} \text {. } \\
\text { Mazama volcanic ash }\end{array}$ \\
\hline $\mathrm{RC}$ & $\begin{array}{l}\text { ASTM C109 Using } \\
\text { equivalent volume of crushed } \\
\text { oyster shells heated to } 920 \\
\text { degrees Celsius }\end{array}$ & $\begin{array}{l}\text { Replacement of oyster shells } \\
\text { with } 100,150 \text { and } 200 \mathrm{~g} \text { of } \\
\text { Mt. Mazama volcanic ash }\end{array}$ \\
\hline
\end{tabular}


Table 7. Mortar cube mix designs for compressive strength

\begin{tabular}{|l|l|c|c|c|}
\hline & & \multicolumn{3}{|c|}{ Mix Design } \\
\hline Test Sample & Cement type & $\begin{array}{c}\text { Portland } \\
\text { Cement (g) }\end{array}$ & $\begin{array}{c}\text { Alternative } \\
\text { cement weight (g) }\end{array}$ & $\begin{array}{c}\text { Volcanic } \\
\text { Ash (g) }\end{array}$ \\
\hline SC-0 & Portland cement & 500.0 & 0.0 & 0.0 \\
\hline SC-1 & Portland cement & 400.0 & 0.0 & 100.0 \\
\hline SC-2 & Portland cement & 350.0 & 0.0 & 150.0 \\
\hline SC-3 & Portland cement & 300.0 & 0.0 & 200.0 \\
\hline SC-4 & Portland cement & 200.0 & 0.0 & 300.0 \\
\hline LC-0 & Lime & 0.0 & 263.6 & 0.0 \\
\hline LC-1 & Lime & 0.0 & 210.9 & 100.0 \\
\hline LC-2 & Lime & 0.0 & 184.6 & 150.0 \\
\hline LC-3 & Lime & 0.0 & 158.2 & 200.0 \\
\hline OC-0 & Powdered oyster shell & 0.0 & 234.4 & 0.0 \\
\hline OC-1 & Powdered oyster shell & 0.0 & 187.5 & 100.0 \\
\hline OC-2 & Powdered oyster shell & 0.0 & 164.1 & 150.0 \\
\hline OC-3 & Powdered oyster shell & 0.0 & 140.7 & 200.0 \\
\hline LPC-0 & Lime and portland cement & 100.0 & 210.8 & 0.0 \\
\hline LPC-1 & Lime and portland cement & 80.0 & 168.6 & 100.0 \\
\hline LPC-2 & Lime and portland cement & 70.0 & 147.6 & 150.0 \\
\hline LPC-3 & Lime and portland cement & 60.0 & 126.5 & 200.0 \\
\hline OPC-0 & Powdered oyster shell and portland cement & 100.0 & 187.6 & 0.0 \\
\hline OPC-1 & Powdered oyster shell and portland cement & 80.0 & 150.1 & 100.0 \\
\hline OPC-2 & Powdered oyster shell and portland cement & 70.0 & 131.3 & 150.0 \\
\hline OPC-3 & Powdered oyster shell and portland cement & 60.0 & 112.6 & 200.0 \\
\hline RC-0 & Cooked powdered oyster shell & 0.0 & 213.4 & 0.0 \\
\hline RC-1 & Cooked powdered oyster shell & 0.0 & 170.8 & 100.0 \\
\hline RC-2 & Cooked powdered oyster shell & 0.0 & 149.4 & 150.0 \\
\hline RC-3 & Cooked powdered oyster shell & 0.0 & 128.1 & 200.0 \\
\hline & & & & \\
\hline
\end{tabular}

As described in Sleep and Masley, it was necessary to process the volcanic ash prior to use in portland cement concrete mixes to realize the full potential of the natural pozzolan. The crushing procedure was previously described in this report in the 3.1 Material collected section. This extensive testing program created six separate mix designs to study the effects of replacing portland cement with a natural pozzolan and/or an additional source of calcium hydroxide to form cementitious products.

As shown in Table 4, the volcanic ash used in this study is comprised of primarily silica dioxide. This is very similar in chemical composition to the volcanic ash from the eruption of Mt. St. Helens (Taylor and Lichte, 1980). Volcanic ash is chemically similar to the magma of its source. Basaltic, andesitic and rhyolitic magmas have silica dioxide range from $45 \%$ to $75 \%$, respectively (Langmann, 2013). Understanding the pozzolanic process, other sources of $\mathrm{CaO}$ were investigated, in addition to portland cement, to see if a cementitious material could be formed without its presence in the design. As shown in Sleep and Masley, any replacement of 
portland cement with a naturally occurring material has a significant decrease in embodied energy and carbon dioxide emissions. In this study, Type S lime and oyster shells were investigated to supply $\mathrm{CaO}$. Type $\mathrm{S}$ lime mortar was chosen as it is a known source of cementitious calcium, which should allow for more integration of the different components of the volcanic ash in the final cementitious product (Sleep and Matzen, 2020).

Oyster shells were chosen for the same reason as lime mortar, but with the additional intention of determining a more widely available source of calcium. The lime mortar came in a powdered form, but the oyster shells were acquired as a combination of large flakes to whole shells typically used for poultry egg production. They were processed with the same rock crusher as the volcanic ash. Oyster shells are primarily composed of $\mathrm{CaCO}_{3}$, which is not usable as a hydraulic calcium-base cement. To recover a usable hydraulic cement, the powdered shells were placed in a furnace at temperatures between $900^{\circ} \mathrm{C}$ and $1,000^{\circ} \mathrm{C}$ to burn off $\mathrm{CO}_{2}$ and create $\mathrm{CaO}$. Both were mixed with varying degrees of portland cement, and tested on their own, to determine if they could serve as either an additional supplement in the mix, or a replacement for the portland cement altogether (Sleep and Matzen, 2020).

ASTM C311 was modified to determine the unconfined compressive strength of mortar cubes created with continued replacements of portland cement with volcanic ash as well as other sources of $\mathrm{CaO}$. In addition to altering the amounts of materials tested, the timeframe for testing was extended due to the long-term strength gains typically found with natural pozzolans. ASTM Type 1 mortar cubes were created out of water, portland cement volcanic ash, and graded sand. The sand is a controlled mixture of grain sizes. This is used to reduce variability in strength to only that observed by replacement of portland cement. Following ASTM C311, 500g of portland cement is used with $275 \mathrm{ml}$ of water and 1375g of graded sand. This allows for the creation of six $5 \mathrm{~cm}$ square mortar cubes. For these cubes, $100 \mathrm{~g}$ [M1] of the $500 \mathrm{~g}$ of the portland cement is replaced with the pozzolan of interest. In addition to replacing $100 \mathrm{~g}$ of the portland cement, mortar cubes were created as shown in Table 7.

ASTM C311 states that mortar cubes created in this method should meet $75 \%$ of the control mortar cube strength at 28 days of curing. Variability in strengths measured in Sleep and Masley 2018 made careful determination of this requirement difficult. Here, samples SC-0 and SC-1 show that the volcanic ash, when processed and passed through the No. 200 sieve, has approximately $68 \%$ of the strength of the control specimen. These mortar cubes were created with great care and cured in a controlled environment. Prior to testing for the unconfined strength, sample faces were inspected and any unsmooth or broken surfaces were not used for testing. These results, shown in Table 8, therefore are high confidence. It was shown, however, that the long-term strength gain, common with pozzolans, does surpass the $75 \%$ unconfined strength requirement with 84 days of curing.

In this respect, the pozzolan does not meet strength activity requirements to be classified as a Class N pozzolan. However, as indicated by this testing, the volcanic as does function as a natural pozzolan as indicated by long-term strength gains. This testing can be used to determine strength as a function of time for replacements of portland cement with volcanic ash. Engineers can determine if the strength necessary at times shorter than 84 days of curing would be adequate. It is possible to increase early strength of concrete mixes with a variety of admixtures. 
It has also been shown by researchers (Toutanji et al. 2004, Arel 2016), that silica fume can increase the early strength of concrete mixtures. These researchers have also shown very large increases in short term strength (less than 14 days) when the fineness of the silica fume is increased. Additional admixtures, such as silica fume, or an increase in the fineness of the volcanic ash, would both increase the short term strength of the mix.

Table 8. Unconfined strength of mortar cubes following the ASTM C311 procedure replacing portland cement with processed volcanic ash

\begin{tabular}{|l|r|r|r|r|r|r|r|r|}
\hline \multicolumn{10}{|c|}{ Cure Time (days) } \\
\hline & & & & & & & \\
& & 7 & 28 & 42 & 56 & 70 & 84 \\
\hline Sample & \multicolumn{8}{|c|}{ Percentage of Control Strength (SC-0) } \\
\hline SC-0 & & $100 \%$ & $100 \%$ & $100 \%$ & $100 \%$ & $100 \%$ & $100 \%$ & $100 \%$ \\
\hline SC-1 & & $67 \%$ & $67 \%$ & $68 \%$ & $71 \%$ & $74 \%$ & $75 \%$ & $76 \%$ \\
\hline
\end{tabular}

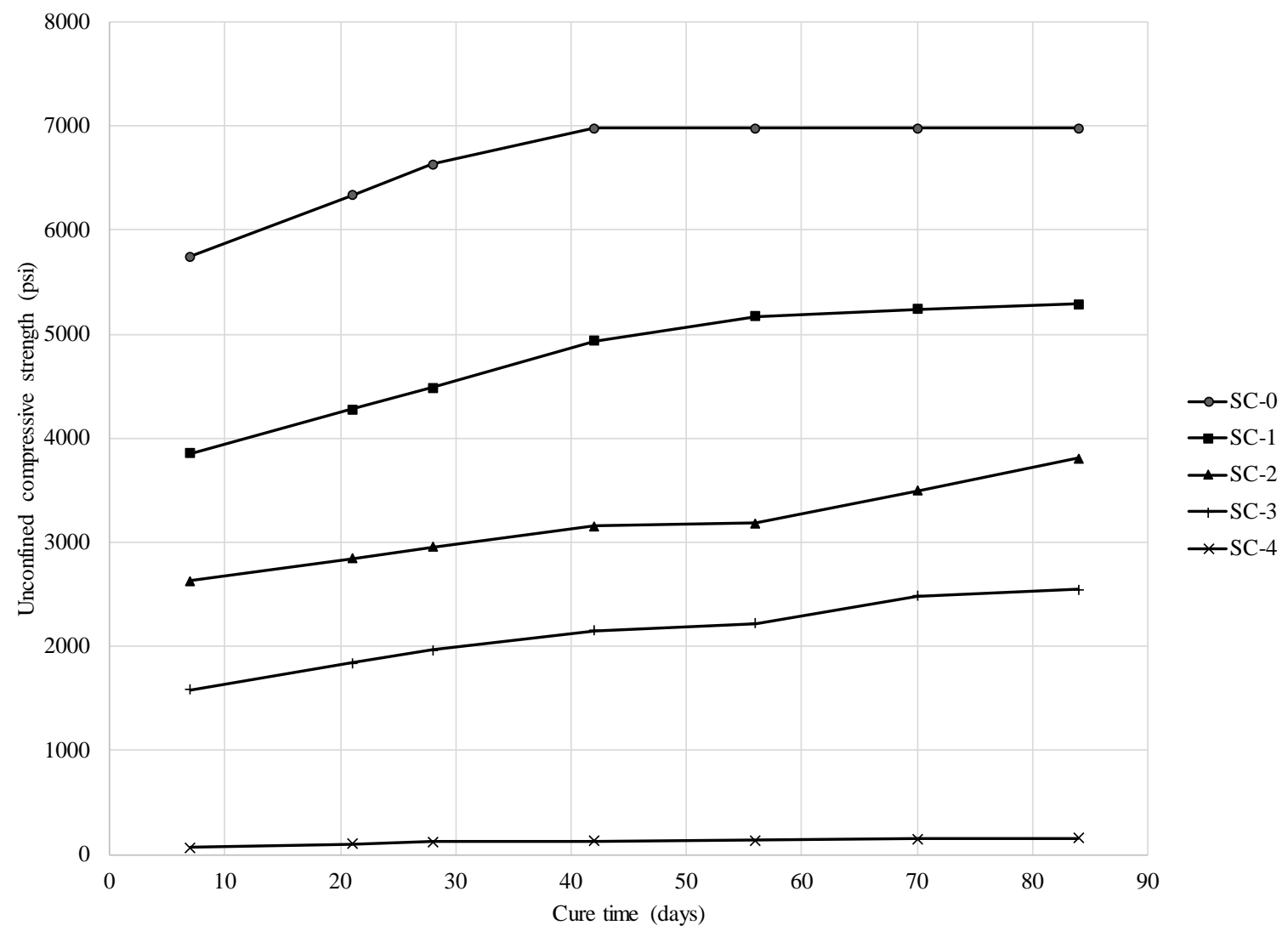

Figure 4 - Unconfined compressive strength with time (SC Samples)

As shown in Figure 4, mortar cubes created with volcanic ash showed appreciable gains in strength between 28 and 84 days of curing. The control, SC-0, displayed no increase in strength between 42 and 84 days of curing. However, samples with volcanic ash showed significant gains in strength between 42 and 84 days. The volcanic ash samples, SC-1 to SC-4, were 
measured to have $6 \%, 16 \%, 17 \%$ and $17 \%$ unconfined compressive strength increases between 42 and 84 days of curing.

Results of the unconfined compressive strength samples LC, OC, LPC, OPC and RC, as described in Table 7, are included in the appendix. Any mortar cubes created with less than $300 \mathrm{~g}$ of portland cement were deemed too weak to support further testing. Unconfined compressive strength of all samples was an order of magnitude or weaker than the control sample, SC-0. However, a few useful observations can be made while reviewing the data. Figure 5 shows the unconfined compressive strength of all mortar cubes created except SC samples. Each individual mix is displayed in the appendix. The samples LC, OC, LPC, OPC and RC all show appreciable gains in unconfined compressive strength between 42 and 84 days. Observing the correlation coefficients between unconfined compressive strength and age of sample (Table 9) shows a positive correlation between 7 and 84 days and 42 and 84 days. This confirms the long-term pozzolanic strength gain of processed Mt. Mazama volcanic ash.

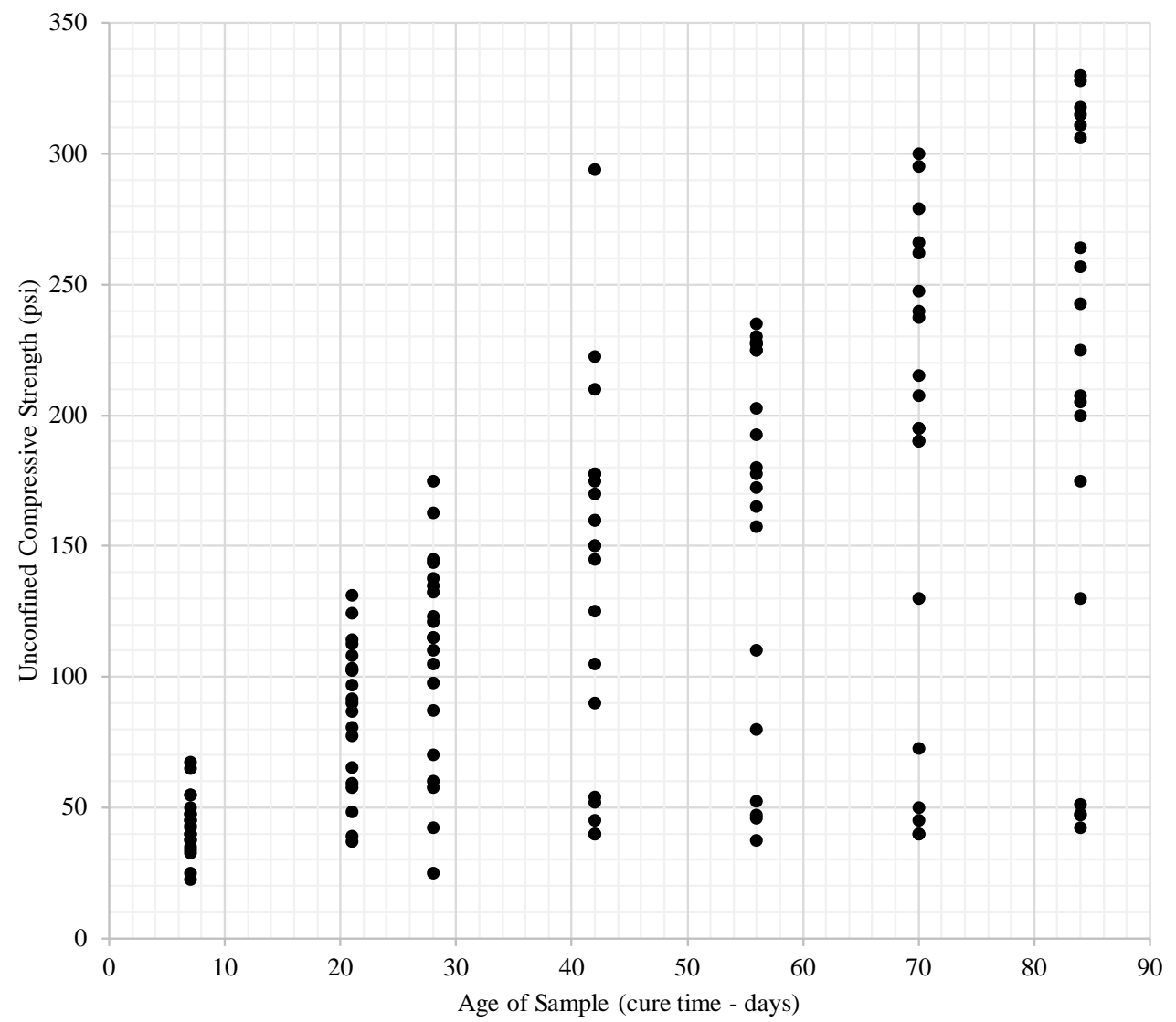

Figure 5 - Unconfined compressive strength of all mortar cubes (excluding control SC group)

Table 9. Correlation coefficients of all mortar cube data from 7-84 days and from 42-84 days (excluding control SC group)

\begin{tabular}{|c|c|}
\hline Sample Age & Correlation Coefficient \\
\hline 7-84 Days & 0.64 \\
\hline 42-84 Days & 0.34 \\
\hline
\end{tabular}




\subsection{INFILTRATION}

This test was devised to determine how various gravel materials reacted to different cementitious mixes. The objective of this testing was twofold: to determine if topical treatment would infiltrate deep enough into the chosen gravel material and how well the cementitious mix binds the gravel material together. Infiltration depth is important as a deeper infiltration would allow for reinforcement and stabilization of the gravel subsurface. Material binding, the other purpose of this test, shows how much of the available subsurface has been reinforced.

Approximately $2400 \mathrm{~g}$ of gravel material is either gathered or created for the gravel trail of interest. This material is compacted into a plastic cylinder with a 4in $(10 \mathrm{~cm})$ diameter and 8in $(20 \mathrm{~cm})$ depth that has been lined with two mold liners for ease of sample removal. Compaction is done over three layers, with each being compacted 25 times with a steel tamping rod. Molds are weighed with liners before material is added to them, and that weight is removed from the weight of the sample after compaction to determine the weight of the aggregate. The weight of applied cementitious slurries are calculated to be $5 \%$ of the aggregate's weight in the sample.

Cementitious mix materials include water, portland cement and Mt. Mazama volcanic ash. Additional admixtures, such as plasticizers, were not used in this study. Mixes are designated by their percentage water content over the ratio of volcanic ash to portland cement. For example, a mix that is $60 \%$ water, $24 \%$ volcanic ash, and 16\% Portland cement would be labeled 60/150. Dry components are weighed first and mixed before water is weighed and slowly added to reduce powder clumping when stirring the mix. Mixes are applied to the surface of the aggregate sample in an even coating. Samples are then sealed to retain moisture and allowed to cure for one week before they are opened and extracted.

Samples are weighed in the mold before careful extraction. Extracted samples are laid on their side next to a measuring device, typically a tape measure. Any unbound aggregate is removed from the testing and discarded. Unbound aggregate is classified as aggregate that does not remain attached when the sample is removed and any aggregate that falls off during handling of the sample. After the sample has been extracted and laid on its side, the distance along the sample from the deepest point from the surface is recorded before the sample is weighed. Some samples, primarily with higher water contents, had solid discs of cured cementitious material at the bottom of the mold. These were classified as having a full infiltration depth if they had bound components throughout the sample, proving the cementitious mix fully infiltrated the material.

Eleven aggregate gradations and combinations were used to determine relationships between grain size distribution characteristics and infiltration test results. Each gradation had three samples created for a volcanic ash to portland cement ratio of 1.5 and percentage water contents of $50 \%, 60 \%$, and $70 \%$. For comparison with firmness and stability testing performed in the field, samples were created using aggregate mixes created using the grain size distribution curve of the accessible geotrail located to the east of Oregon Institute of Technology's Klamath Falls campus. Geotrail samples were treated with cementitious mixes of 1.25, 1.5, and 1.75 ash to cement ratios, 50\%, 60\%, 70\% percentage water contents, as well as three commercial aggregate 
stabilizers. Table 10, located below, provides more detailed descriptions of each aggregate used, as well as a list of cementitious mixes they were treated with.

Table 10. Infiltration test materials with descriptions and applied cementitious mixes

\begin{tabular}{|c|c|c|}
\hline Material & Justification/Reasoning & $\begin{array}{l}\text { Cementitious Mixes } \\
\text { Applied }\end{array}$ \\
\hline $\begin{array}{l}\text { M1.0.0 } \\
\text { M1.1.0 } \\
\text { M1.1.1 }\end{array}$ & $\begin{array}{l}\text { M1 materials were chosen to determine effect of } \\
\text { topical application on angular gravels. Subsets were } \\
\text { chosen to represent potential trail gradations. }\end{array}$ & $50 / 150,60 / 150,70 / 150$ \\
\hline $\begin{array}{l}\text { M2.0.0 } \\
\text { M2.0.1 }\end{array}$ & $\begin{array}{l}\text { M2 materials were chosen to look at the effects of two } \\
\text { layered materials. Subsets were chosen to represent } \\
\text { potential trail gradations. }\end{array}$ & $50 / 150,60 / 150,70 / 150$ \\
\hline $\begin{array}{l}\text { M3.0.0 } \\
\text { M3.0.1 }\end{array}$ & $\begin{array}{l}\text { M3 materials were based on the specifications of } \\
\text { Montana trails. M3.0.1 is a direct interpretation of } \\
\text { specification while M3.0.0 includes other sizes to } \\
\text { incorporate a higher number of finer aggregates. }\end{array}$ & $50 / 150,60 / 150,70 / 150$ \\
\hline M5.0.1 & $\begin{array}{l}\text { M5.0.1 was based on the subgrade for M3.0.1 to } \\
\text { determine its effectiveness on its own. }\end{array}$ & $50 / 150,60 / 150,70 / 150$ \\
\hline Geotrail & $\begin{array}{l}\text { Made to mimic the existing gravel used in the trail of } \\
\text { interest on the east end of OIT campus. }\end{array}$ & $50 / 150,60 / 150,70 / 150$ \\
\hline M6.0.0 & $\begin{array}{l}\text { Recreation of C1 with different sizes to illustrate } \\
\text { differences in results based on gravel characteristics. }\end{array}$ & $50 / 150,60 / 150,70 / 150$ \\
\hline C1 & $\begin{array}{l}\text { Initial available coarse gravel. Mostly used for proof- } \\
\text { of-concept and process refinement testing as well as } \\
\text { possible trail aggregate. }\end{array}$ & $\begin{array}{l}\text { 67/100, 67/900, 60/100, } \\
\text { 60/150, 60/233, 60/400, } \\
\text { 60/900 all with volcanic } \\
\text { ash passing the \#4 sieve. } \\
\text { 60/100, 60/150, 60/233, } \\
\text { 60/400, 60/900 all with } \\
\text { volcanic ash roughly } \\
\text { crushed. } \\
\text { 60/100, 60/150, 60/233, } \\
\text { 60/400, 60/900 all with } \\
\text { volcanic ash passing the } \\
\text { \#200 sieve. }\end{array}$ \\
\hline
\end{tabular}

The first samples created made use of available coarse aggregate to verify the validity of this test. Through controlled trial and error, it was determined that a finer volcanic ash yielded higher amounts of bound material as well as further infiltration into the sample, as well as an ideal water percentage of $60 \%$ for the cementitious mixes, and a volcanic ash to portland cement ratio of 1.5. (Figure 6, Figure 7). 


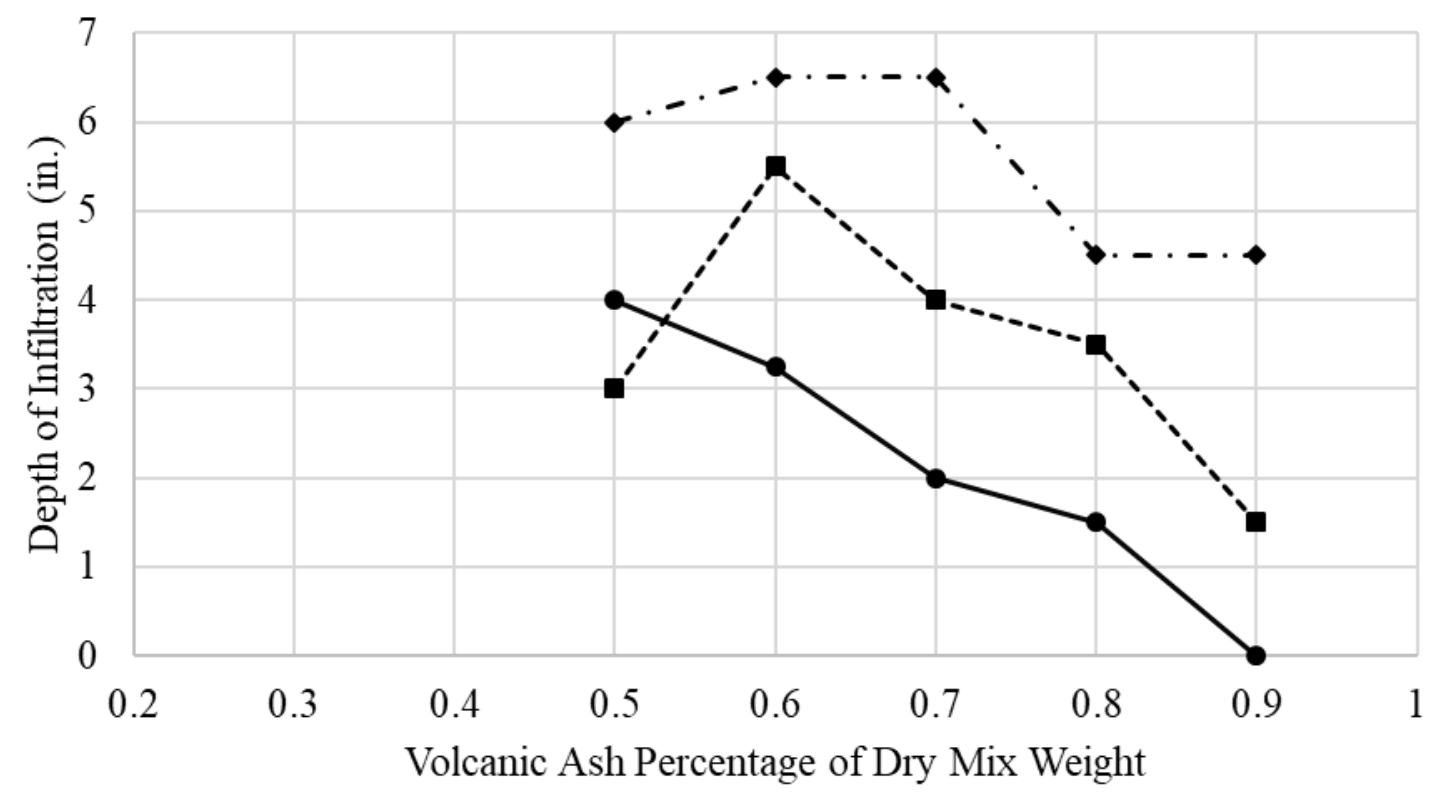

$\longrightarrow$ - Passing \#4 ----Crushed - - Passing \#200

Figure 6 - Depth of infiltration with different levels of volcanic ash processing during initial infiltration testing

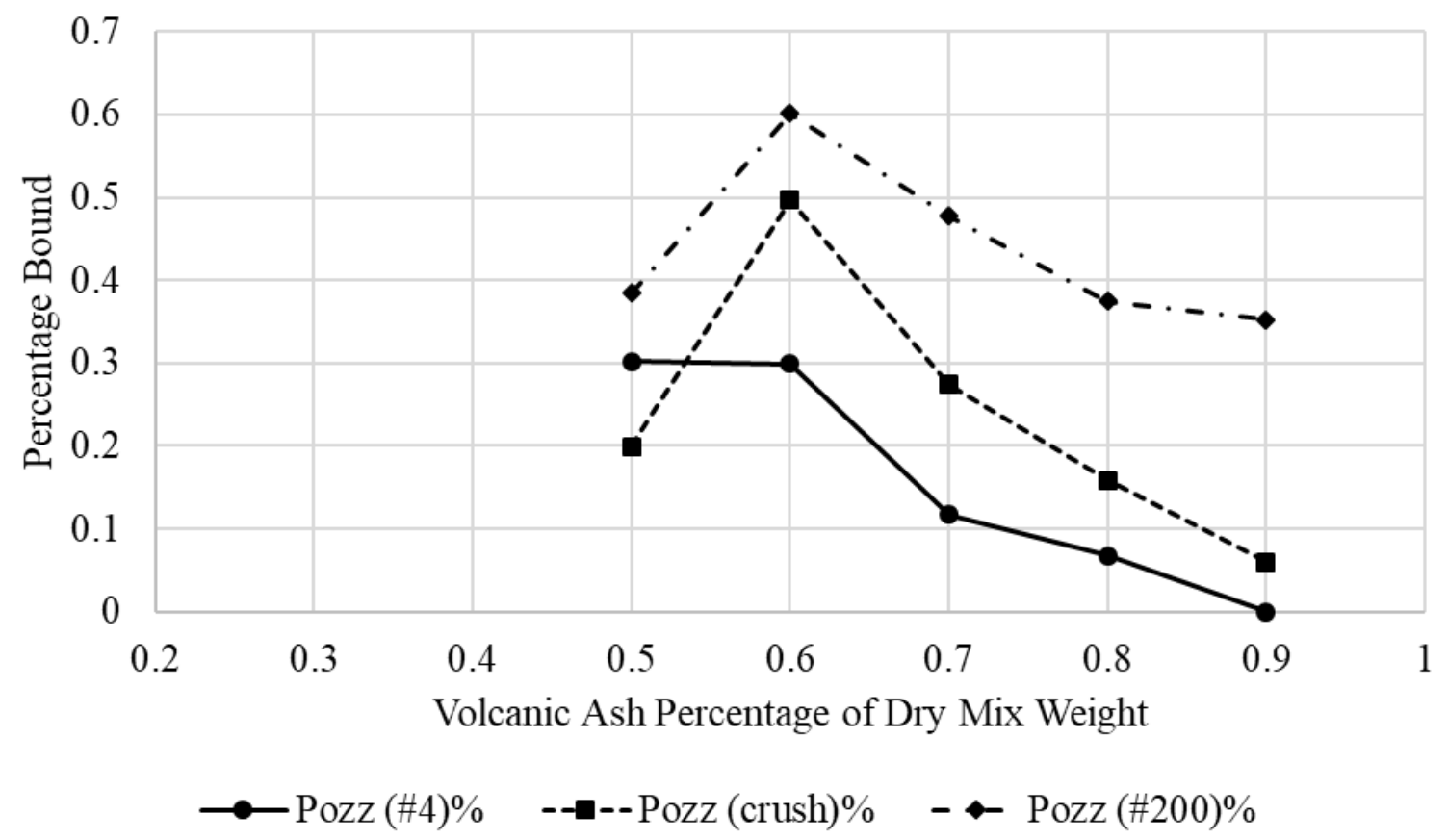

Figure 7 - Percentage of material bound with different levels of volcanic ash processing during initial infiltration testing

When looking at data for samples that were not fully infiltrated, there is a positive correlation between the amount of bound material in a treated sample and the infiltration of the cementitious 
mix applied (Figure 8). There is not a strong correlation between aggregate characteristics and infiltration testing results.

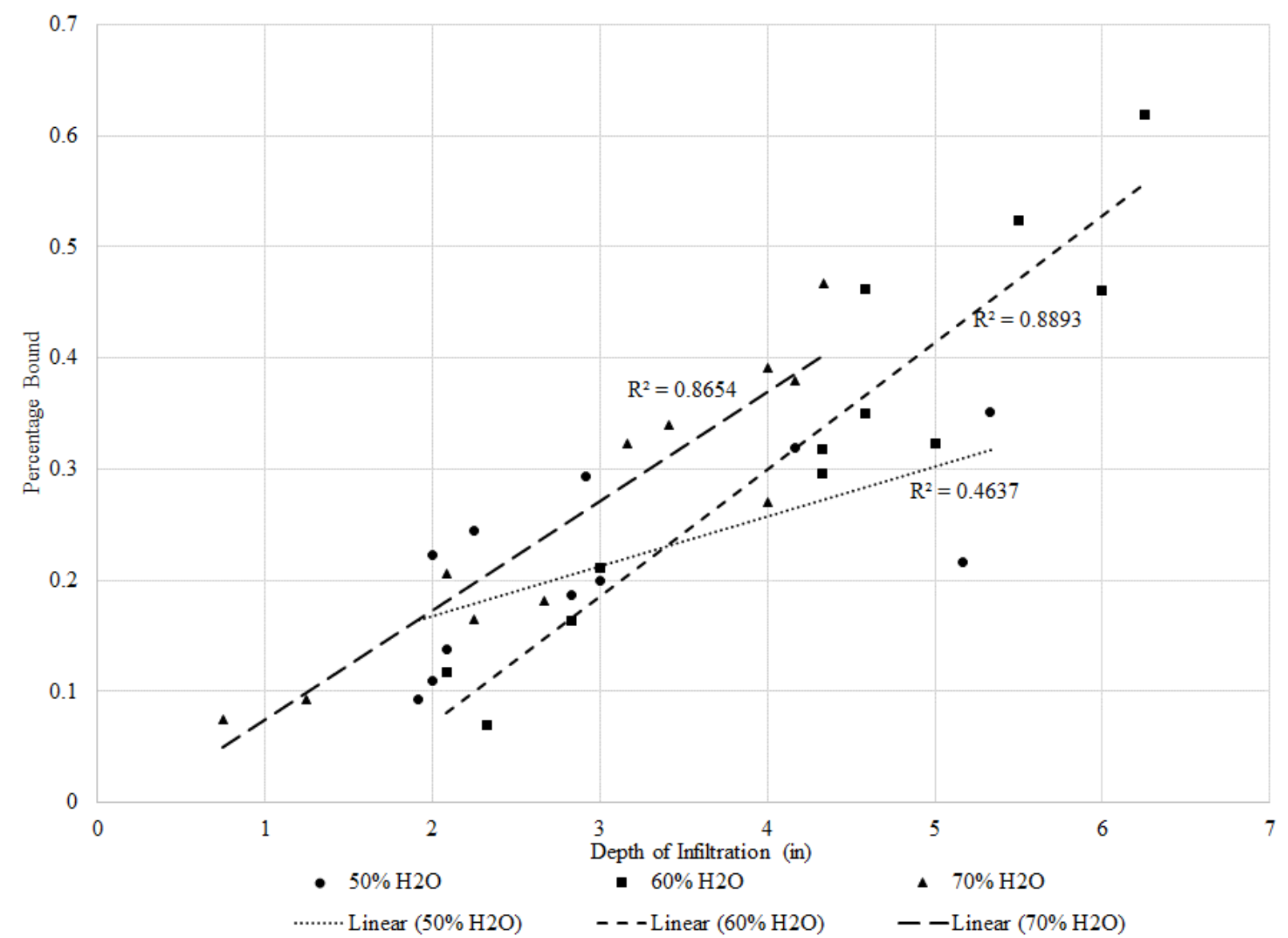

Figure 8 - Depth of infiltration compared against percentage of bound material for a 1.5 volcanic ash ratio, separated by mixture water content

Testing conducted on the aggregate mix used for the construction of the OIT Accessible Geotrail included different ratios of volcanic ash to portland cement. These tests showed a positive trend between the amount of bound material and the percentage of water present in the applied cementitious mix for each ratio of volcanic ash to portland cement applied (Figure 9 and Figure 10). It also shows a parabolic relationship between the ratio of volcanic ash and portland cement in the mix, with the 1.5 ratio as the trough of the parabola, with 1.25 and 1.75 volcanic ash ratios yielding higher binding and deeper infiltration. Infiltration depth for all three volcanic ash ratios does not have an increasing relationship with an increasing amount of water in the cementitious mix. Instead, both the 1.25 and 1.75 ratios peak at $60 \%$ of the mix being water while the 1.5 ratio has a negative relationship. 


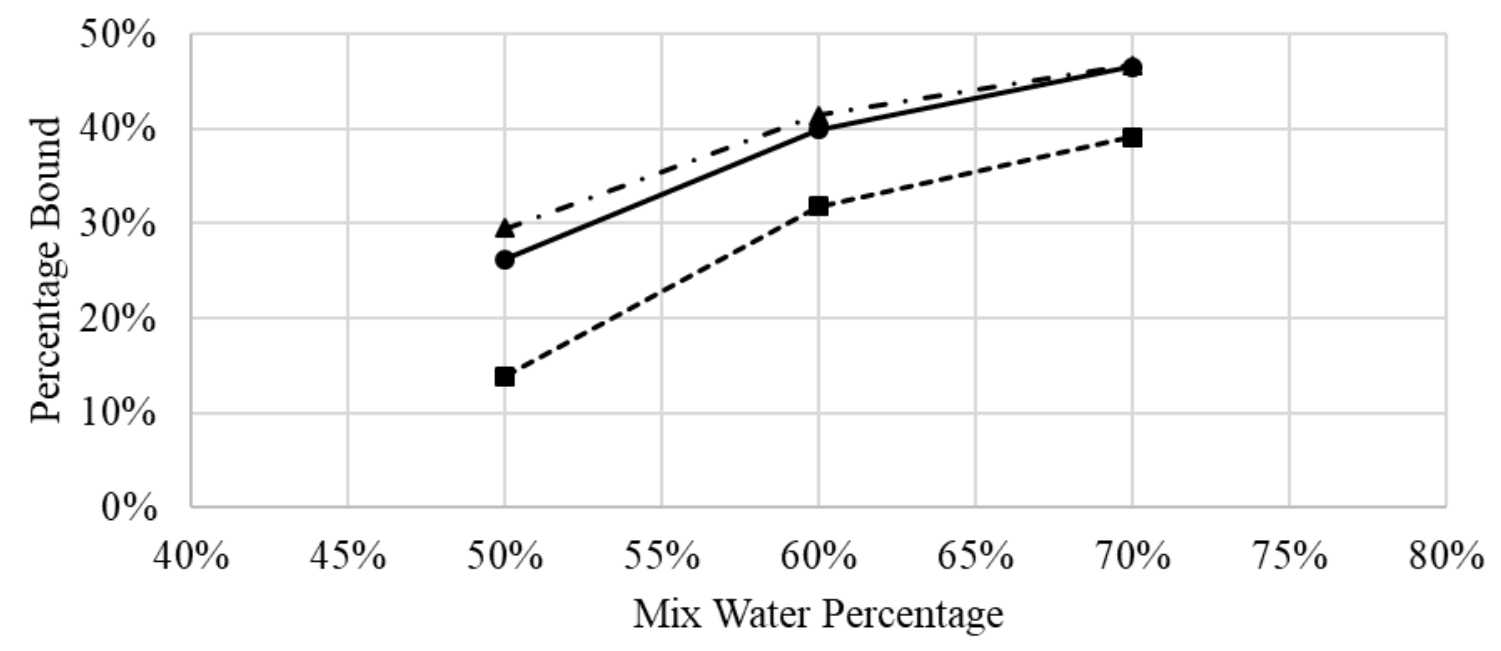

$\longrightarrow$ - 1.25 Volcanic Ash Ratio ----- 1.5 Volcanic Ash Ratio

- $₫$ - 1.75 Volcanic Ash Ratio

Figure 9 - Percentage of bound material for recreated geotrail infiltration tests

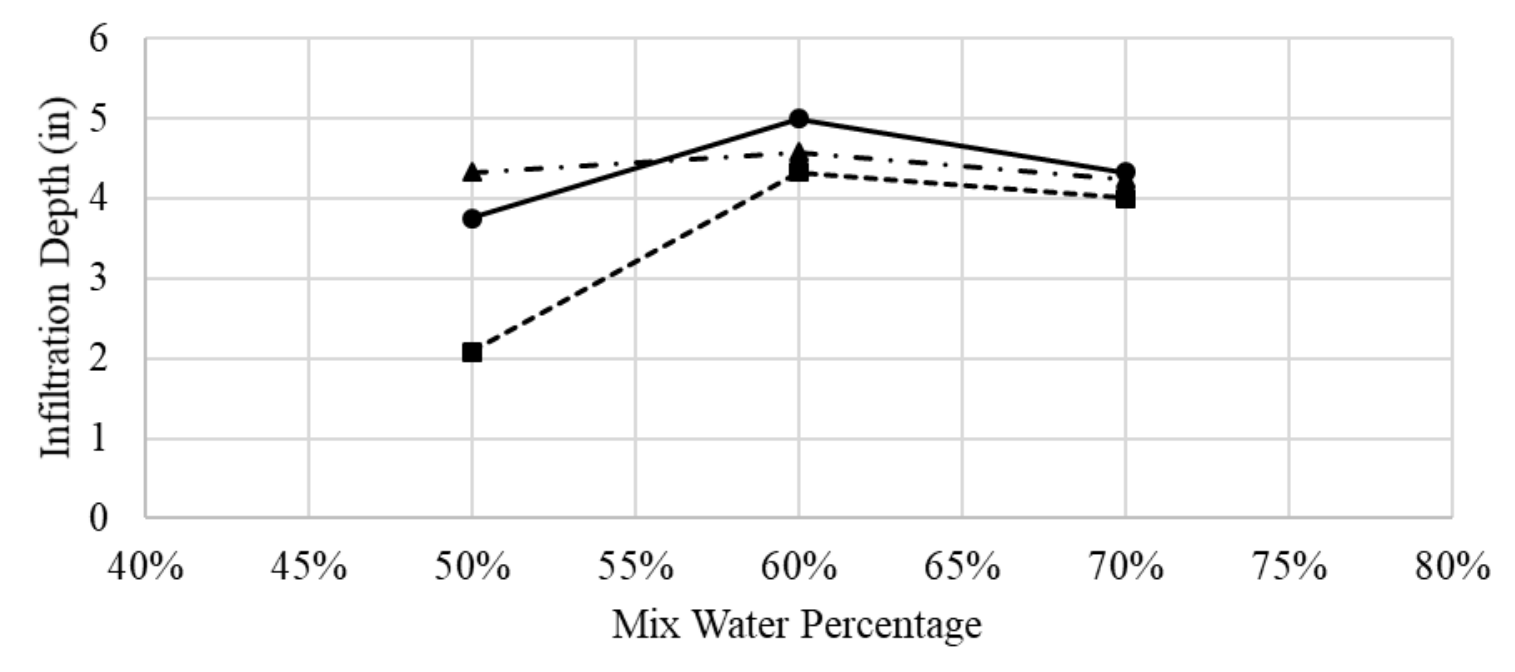

$\longrightarrow$ 1.25 Voclanic Ash Ratio ---- 1.5 Volcanic Ash Ratio

- $\triangle 1.75$ Volcanic Ash Ratio

Figure 10 - Infiltration depth for recreated geotrail infiltration tests

Geotrail aggregate was also treated with three commercial stabilizers to verify their claims of being topically applicable before applying them to sections of the OIT geotrail. The stabilizers used were G3 soil stabilizer, Klingstone Amber, and SoilTac liquid topical. SoilTac liquid topical stabilizer was diluted in increasing increments of $10 \%$ water content due to a mention of a recommended dilution for application determined by the aggregate being stabilized, but no guidance. Infiltration depth and bound material results can be seen in Table 11 for the G3 and Klingstone stabilizers, as well as the results for the other geotrail infiltration tests, excluding the SoilTac samples. The results for the SoilTac stabilizer are shown in Figure 11 on opposing axes 
to illustrate changes due to dilution. A mixture of 30\% SoilTac stabilizer and 70\% water by weight was chosen for firmness and stability applications due to that mixture demonstrating a high material binding potential, as well as not fully infiltrating the sample.

Table 11. Results of cementitious mixes on recreated geotrail samples during infiltration testing

\begin{tabular}{|c|c|c|}
\hline Name & $\begin{array}{c}\text { Depth of } \\
\text { Infiltration } \\
\text { (in.) }\end{array}$ & $\begin{array}{c}\text { Percentage } \\
\text { Bound }\end{array}$ \\
\hline $50 / 125$ & 3.75 & $26.3 \%$ \\
\hline $50 / 150$ & 2.08 & $13.8 \%$ \\
\hline $50 / 175$ & 4.33 & $29.5 \%$ \\
\hline $60 / 125$ & 5.00 & $39.9 \%$ \\
\hline $60 / 150$ & 4.33 & $31.8 \%$ \\
\hline $60 / 175$ & 4.58 & $41.4 \%$ \\
\hline $70 / 125$ & 4.33 & $46.5 \%$ \\
\hline $70 / 150$ & 4.00 & $39.2 \%$ \\
\hline $70 / 175$ & 4.25 & $46.7 \%$ \\
\hline G3 Soil Stabilizer & 7.00 & $9.9 \%$ \\
\hline Klingstone Amber & 6.00 & $47.3 \%$ \\
\hline
\end{tabular}

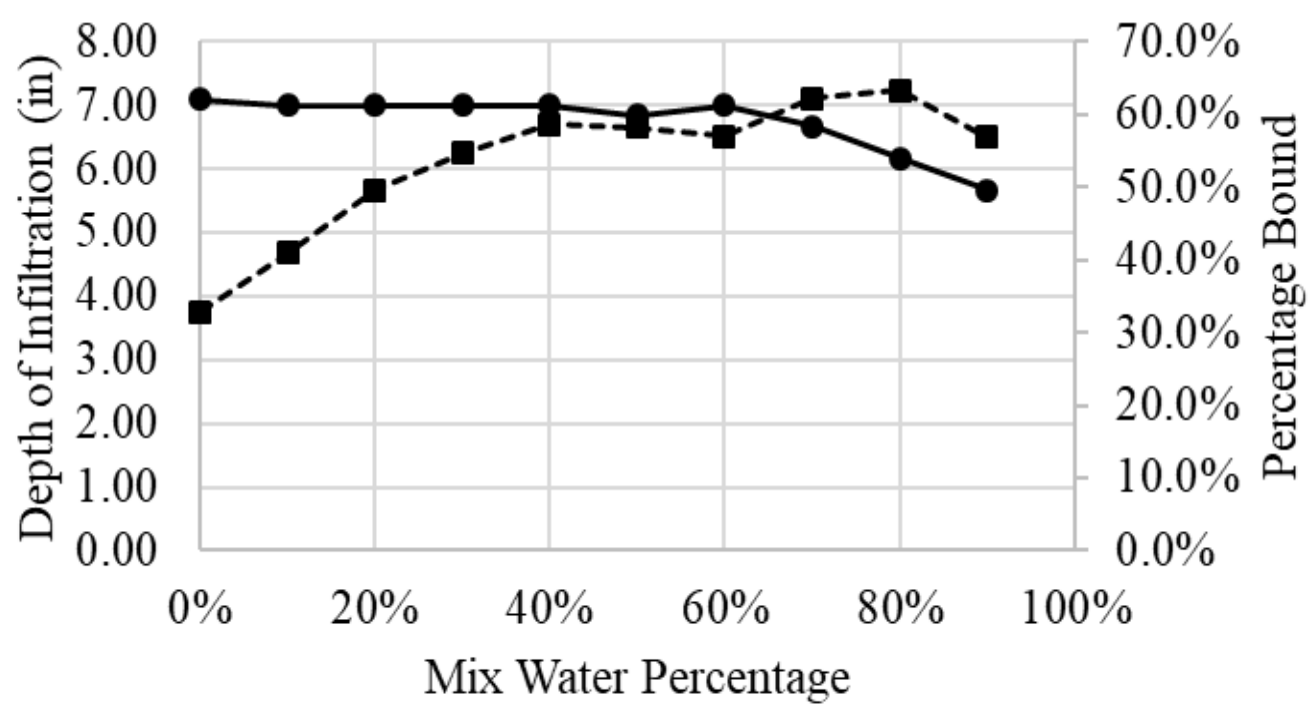

$\rightarrow$ Depth of Infiltration (in.) --ロ--Percentage Bound

Figure 11 - Results for SoilTac stabilizer infiltration tests plotted opposite each other 


\subsection{LAB-SCALE TRAIL TESTING}

Firmness and stability testing were conducted in order to determine the efficacy of the cementitious mixes as stabilizers with regard to accessibility. Frames were constructed to facilitate this testing in the controlled environment of the lab in order to first prove the mixes provided an improvement in firmness or stability. Conducting the tests in controlled frames allowed for control of the created surface without the need for creating large segments and control of the environment in which treated trail segments cure. This testing was completed to determine the following:

1. Effect of compaction on firmness and stability

2. Effect of confinement on firmness and stability

3. Determination of appropriate method of mix placement

\subsubsection{Lab-Scale Device}

Two frames were constructed for testing chosen trail materials in a controlled environment (Figure 12). The frames were constructed from dimensioned lumber, a top section comprised of $2 \times 12$ pine and a lower section comprised of $2 \times 4$ pine, and a sheet of steel secured between the two wooden sections. Structural support for the frame is provided by the lower portion, comprised of $2 \times 4$ dimensioned lumber. Supports were created with a connected series of beams matching the outer dimensioning of the top section with extra bracing provided in the center to prevent deformation of the steel sheet. For the top section, a rectangular frame was constructed with interior dimensions of 72in $(182 \mathrm{~cm})$ length and 36in $(91 \mathrm{~cm})$ width with the use of $2 \times 12$ nominal dimensioned lumber. The steel sheet is fastened first to the support section, and then the top section. Short lengths of lumber were affixed to the sides to increase structural stability of the upper section of the frame, and provide more connection between the upper and lower sections.

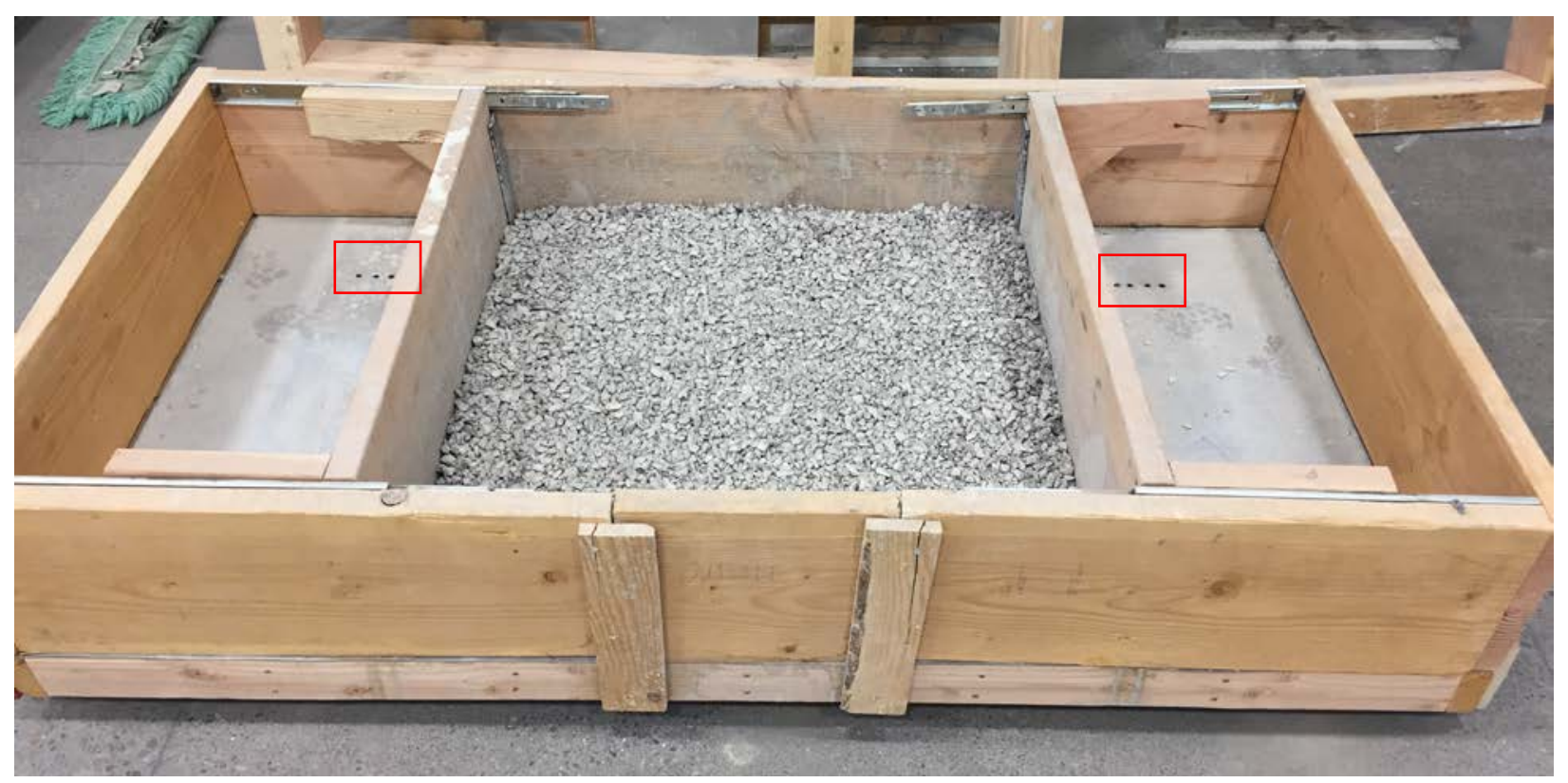

Figure 12 - Lab-scale trail testing device (red outline showing pin locations to move the walls to investigate confinement effects) 
Affixed to the lower section through the steel sheet were two vertical lengths of $2 \times 12$ lumber on slide rails. The walls were positioned perpendicular to the length of the frame inside the upper section with a distance of 36in $(91 \mathrm{~cm})$ between the side facing the other sliding wall. Each inner wall was designed with the ability and clearance to slide away from the central area a total of $15 \mathrm{~cm}$. Long braces were affixed to the sliding walls of the first testing frame along the bottom with two holes provided for lock-pins to hold the wall at 1 in $(25 \mathrm{~mm})$ intervals, totaling seven positions for each wall. Vertical walls created a square area that is $36 \mathrm{in}(91 \mathrm{~cm})$ to a side in the center of the frame where trail material is placed for testing. The walls attached to sliders allow for the expansion of the central area to a rectangular are that is $36 \mathrm{in}(91 \mathrm{~cm})$ by $72 \mathrm{in}(121 \mathrm{~cm})$. This can be used to simulate either the removal of supports, or to accommodate more trail material.

Due to the lack of upper bracing, the walls canted outward when a vibratory compactor was used to compact the chosen trail material. To prevent this from happening with the second frame, upper supports were added with holes following a similar lock-pin spacing. Lock-pins used are $1 \mathrm{~cm}$ diameter. Sections in each of the long walls are cut so as to be removable to allow for easier clearing of trail material after testing. Marks are placed on the removable portions to measure the depth of trail material located in the frame. Each frame was fixed with casters at the corners of the central $91 \mathrm{~cm}$ square area to allow for movement of the frame while preventing excess deformation due to the loading of trail material.

Trail material is placed in the frame, tested for base firmness and stability, and then treated with a cementitious mix. Originally, a sprayer was the intended method of application, with the intention of allowing the use of portable personal dispensing units. Due to sediment in the mixes, the sprayers were only partially successful, causing many applications to be applied by evenly pouring over the surface. Surface testing was conducted with the BDRP. Two gradations of gravel were used in the lab scale device. Gravel C1 and the geotrail material were both used in the lab device. Gradation C1 was chosen as a coarse gradation. The geotrail material was chosen because it is the material used in the field applications discussed in other sections of this report. Both material gradations are shown in Figure 13. For the lab-scale testing, gravel was placed to a depth of 6.5 inches. 


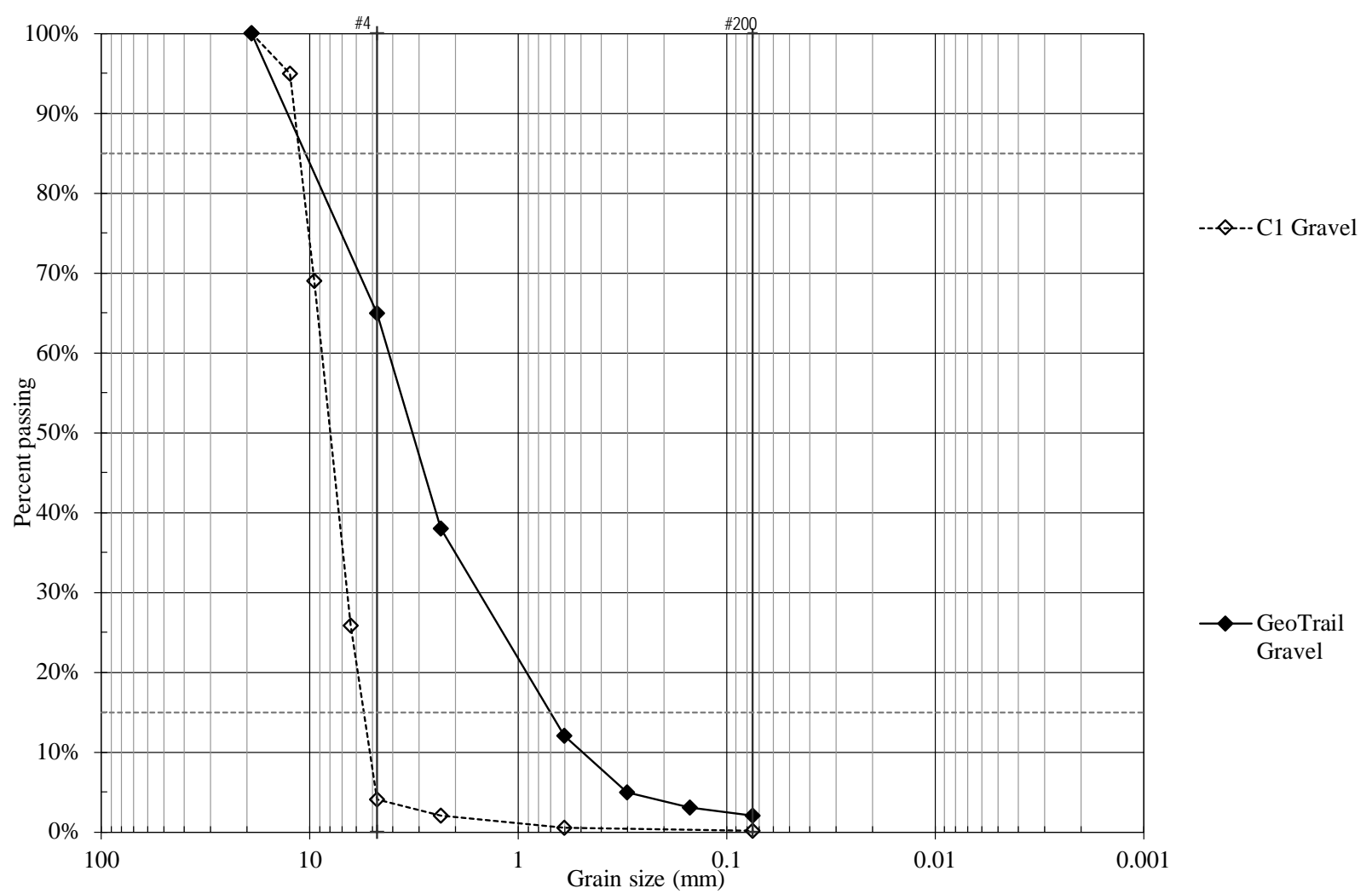

Figure 13 - Two gradations of gravel used in the lab-scale testing device

\subsubsection{Effects of Compaction and Confinement}

The first experiment conducted with the lab-scale testing device was with an untreated gravel (C1 from Figure 13). The material was placed to a depth of 6.5 inches in the device. One device was created with uncompacted material, and the other was compacted with a vibratory plate compactor. For the compacted and uncompacted test specimens, the firmness and stability measurements were taken with the BDRP. The walls were then moved from pin positions 0-6, and BDRP measurements were taken again.

As shown in Figure 14 and Figure 15, moving the walls only affected the compacted gravel. It is interesting to note that the gravel becomes more stable as the confining walls are moved outward. Wall position and movement appears to have no significant, or constant, effect on the uncompacted material. Wall movement, or confinement, does not appear to have a significant influence on firmness and stability of the trails tested in the lab-scale device.

Table 12 shows the change in firmness and stability measured by the BDRP between the compacted and uncompacted specimens. These small changes indicate that compaction of this specimen does not greatly improve firmness or stability. In addition, the three commercial stabilizers tested and described later in this report recommend no compaction prior to placement of the stabilizer. 
Table 12. Change in firmness and stability (percentage increase) between compacted and uncompacted specimens $\mathrm{C} 1$ in the lab-scale trail testing device

\begin{tabular}{|c|c|c|c|}
\hline Pin Position & Firmness & Stability & Firmness and Stability \\
\hline 0 & $20 \%$ & $5 \%$ & $7 \%$ \\
\hline 1 & $13 \%$ & $8 \%$ & $9 \%$ \\
\hline 2 & $16 \%$ & $4 \%$ & $6 \%$ \\
\hline 3 & $13 \%$ & $5 \%$ & $6 \%$ \\
\hline 4 & $4 \%$ & $4 \%$ & $3 \%$ \\
\hline 5 & $18 \%$ & $9 \%$ & $11 \%$ \\
\hline
\end{tabular}

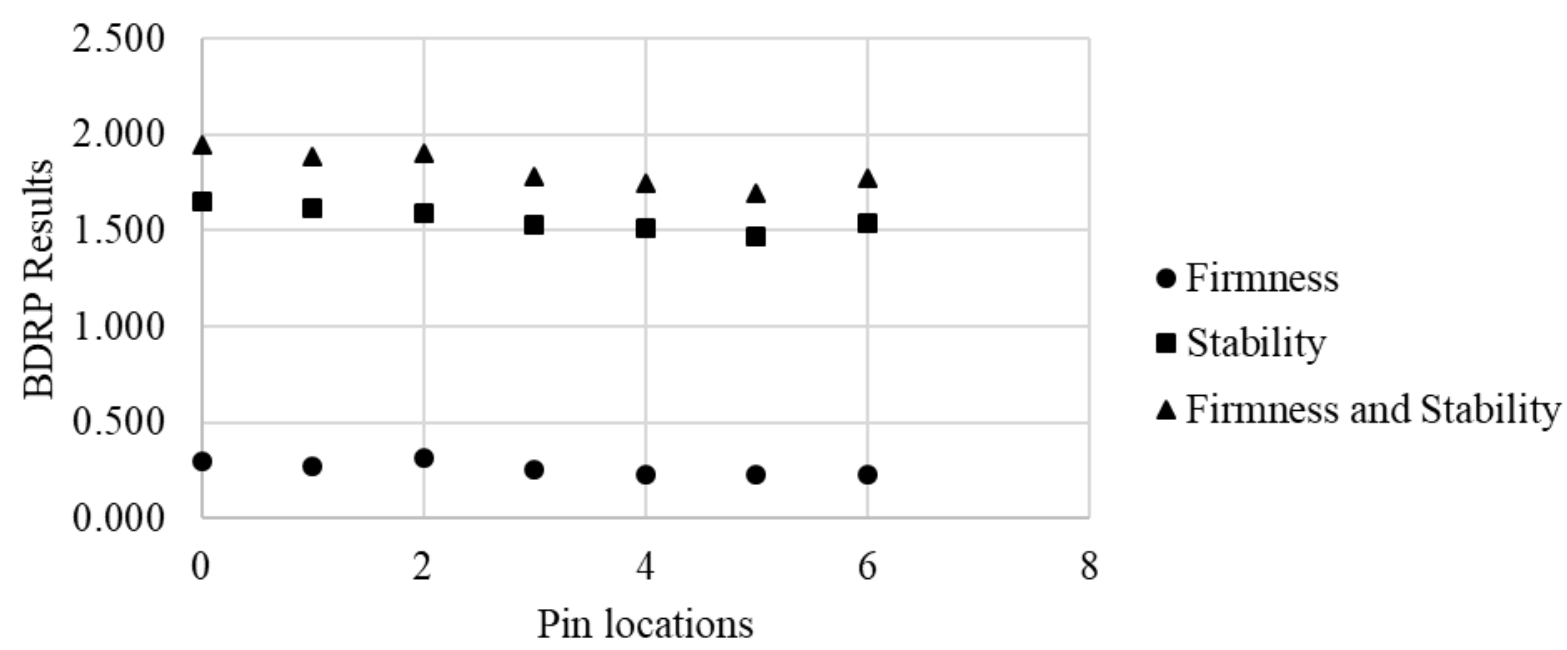

Figure 14 - Firmness and stability for gravel in lab-scale firmness and stability testing that was compacted by a vibratory compactor (material C1)

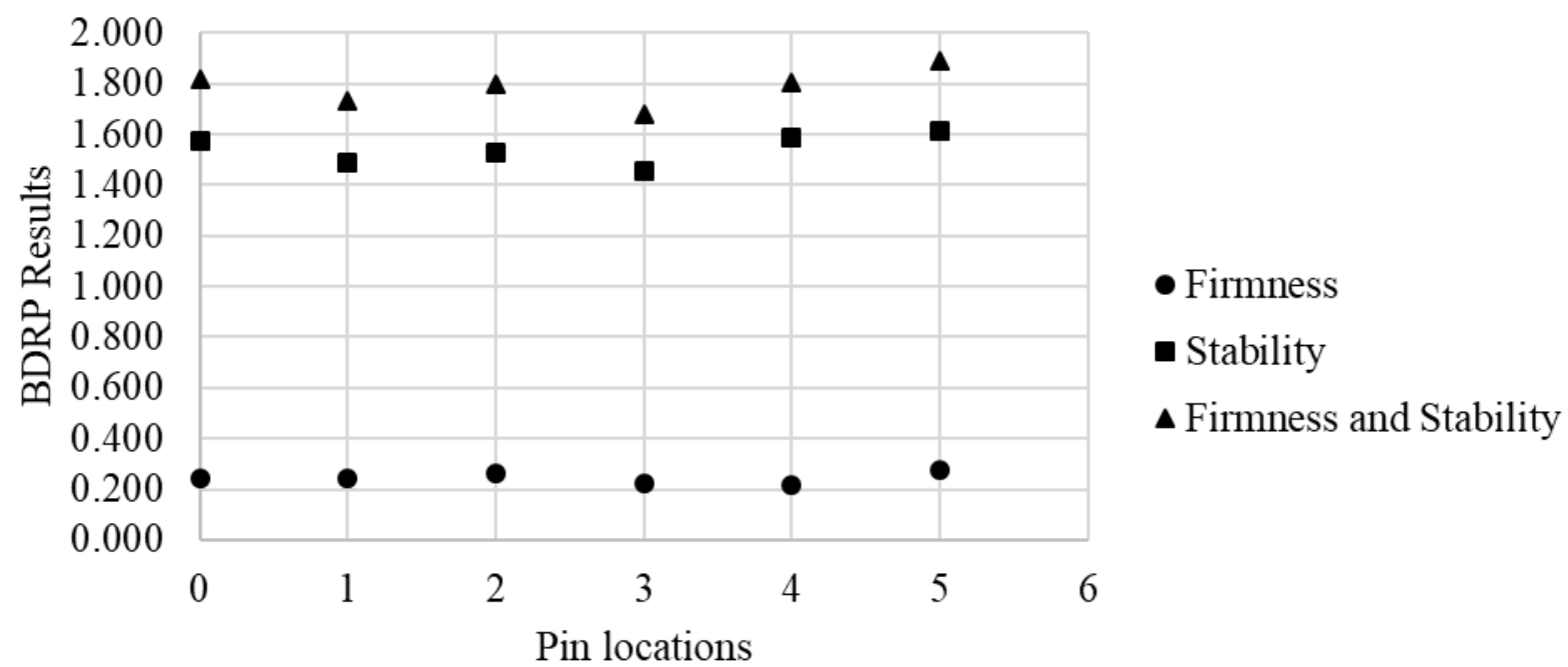

Figure 15 - Firmness and stability for gravel in lab-scale firmness and stability testing that was not compacted by a vibratory compactor (material C1) 


\subsubsection{Treatment of Lab-Scale Surfaces}

Six separate trial mixes were applied to the lab-scale trail device. Treatment via cementitious mix proved highly successful in increasing the firmness and stability of the treated surface while in the frames. As the frames were designed to determine the effectiveness of topical cementitious treatment, variations in mix design were not investigated during these tests. Mix components, as well as surface materials used, are presented in Table 13. These mixes were applied and left to cure for seven days.

Table 13. Lab-scale firmness and stability testing samples and cementitious mixes by weight

\begin{tabular}{|c|c|c|c|c|c|}
\hline $\begin{array}{c}\text { Sample } \\
\#\end{array}$ & Material & $\begin{array}{c}\text { Mix Water } \\
\text { wt (kg) }\end{array}$ & $\begin{array}{c}\text { Mix Ash wt } \\
(\mathrm{kg})\end{array}$ & $\begin{array}{c}\text { Mix } \\
\text { Cement wt } \\
(\mathrm{kg})\end{array}$ & $\begin{array}{c}\text { Total Mix } \\
\text { Wt (kg) }\end{array}$ \\
\hline 1 & $\begin{array}{c}\text { C1- } \\
\text { gravel }\end{array}$ & 5.40 & 2.18 & 1.45 & 9.03 \\
\hline 2 & Geotrail & 2.09 & 0.82 & 0.54 & 3.45 \\
\hline 3 & $\begin{array}{c}\text { C1- } \\
\text { gravel }\end{array}$ & 7.26 & 2.90 & 1.94 & 12.10 \\
\hline 4 & $\begin{array}{c}\text { C1- } \\
\text { gravel }\end{array}$ & 3.40 & 1.36 & 0.91 & 5.67 \\
\hline 5 & $\begin{array}{c}\text { C1- } \\
\text { gravel }\end{array}$ & 3.40 & 1.36 & 0.91 & 5.67 \\
\hline 6 & $\begin{array}{c}\text { C1- } \\
\text { gravel }\end{array}$ & 3.40 & 1.36 & 0.91 & 5.67 \\
\hline
\end{tabular}

Surface firmness was not greatly improved by treatment, improving by an average of $16.7 \%$ (Table 14). On average, surface stability was increased by an average of $49.4 \%$, with a peak increase of $79.1 \%$. A positive correlation has been shown between the amount of mix used and the effectiveness of the treatment (Figure 16). It should be noted that the greatest improvement in surface stability was not caused by the largest amount of cementitious mix. This could be due to the variability in effectiveness demonstrated by the three samples treated with similar mixes. 
Table 14. Effects of topically applied cementitious mixes during lab-scale firmness and stability testing

\begin{tabular}{|c|c|c|c|c|c|c|}
\hline Sample \# & $\begin{array}{c}\text { Change } \\
\text { in } \\
\text { Firmness }\end{array}$ & $\begin{array}{c}\text { Change in } \\
\text { Stability }\end{array}$ & $\begin{array}{c}\text { Change in } \\
\text { Firmness } \\
\text { and } \\
\text { Stability }\end{array}$ & $\begin{array}{c}\text { \% Change } \\
\text { in } \\
\text { Firmness }\end{array}$ & $\begin{array}{c}\text { \% Change } \\
\text { in } \\
\text { in Stability } \\
\text { Firmness } \\
\text { and } \\
\text { Stability }\end{array}$ \\
\hline 1 & 0.043 & 1.243 & 1.286 & $17.6 \%$ & $79.1 \%$ & $70.9 \%$ \\
\hline 2 & 0.020 & 0.574 & 0.593 & $6.5 \%$ & $38.3 \%$ & $32.9 \%$ \\
\hline 3 & 0.129 & 1.050 & 1.179 & $39.4 \%$ & $71.1 \%$ & $65.3 \%$ \\
\hline 4 & 0.056 & 0.350 & 0.406 & $20.9 \%$ & $23.5 \%$ & $23.1 \%$ \\
\hline 5 & 0.050 & 0.705 & 0.755 & $14.6 \%$ & $46.4 \%$ & $40.6 \%$ \\
\hline 6 & 0.004 & 0.550 & 0.554 & $1.5 \%$ & $38.0 \%$ & $32.2 \%$ \\
\hline Average & 0.050 & 0.746 & 0.796 & $16.7 \%$ & $49.4 \%$ & $44.2 \%$ \\
\hline
\end{tabular}

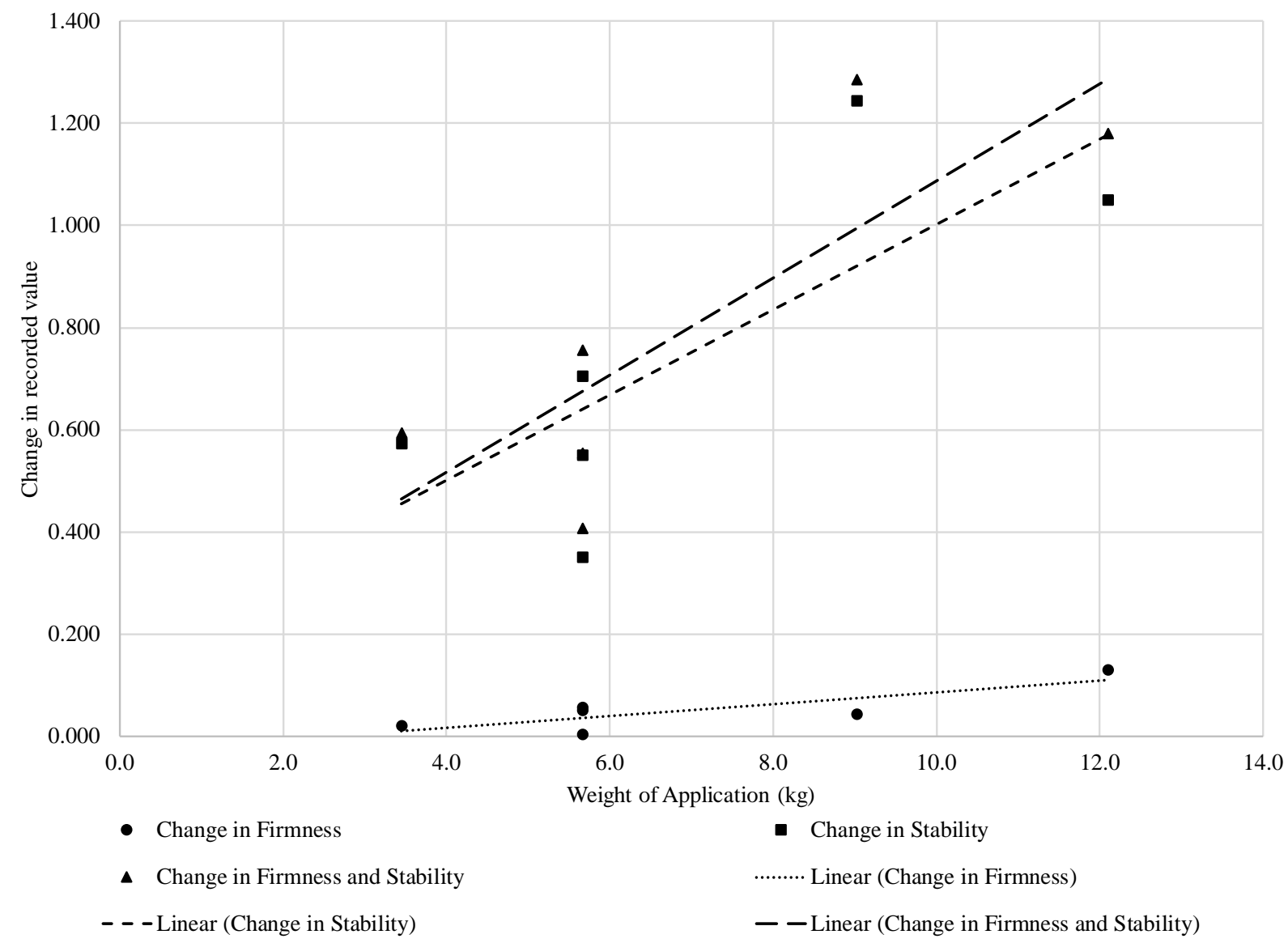

Figure 16 - Weight of cementitious mix applied plotted against the change in firmness and stability after treatment during lab-scale firmness and stability testing 


\subsection{FIELD-SCALE TESTING}

Once treatment was determined to be effective, it was applied to the accessible geotrail located on the Oregon Institute of Technology Klamath Falls campus. Treatments were applied with intention of determining the effectiveness of stabilizing mixes, featured in the infiltration testing, in a practical application. Field applications allow the cementitious mixes more time to establish stabilization, as well as expose them to environmental conditions experienced by the chosen trail. The geotrail site, used for application of trail mixtures, is shown in Figure 17. This trail was constructed to meet ADA accessibility requirements in terms of width and slope.

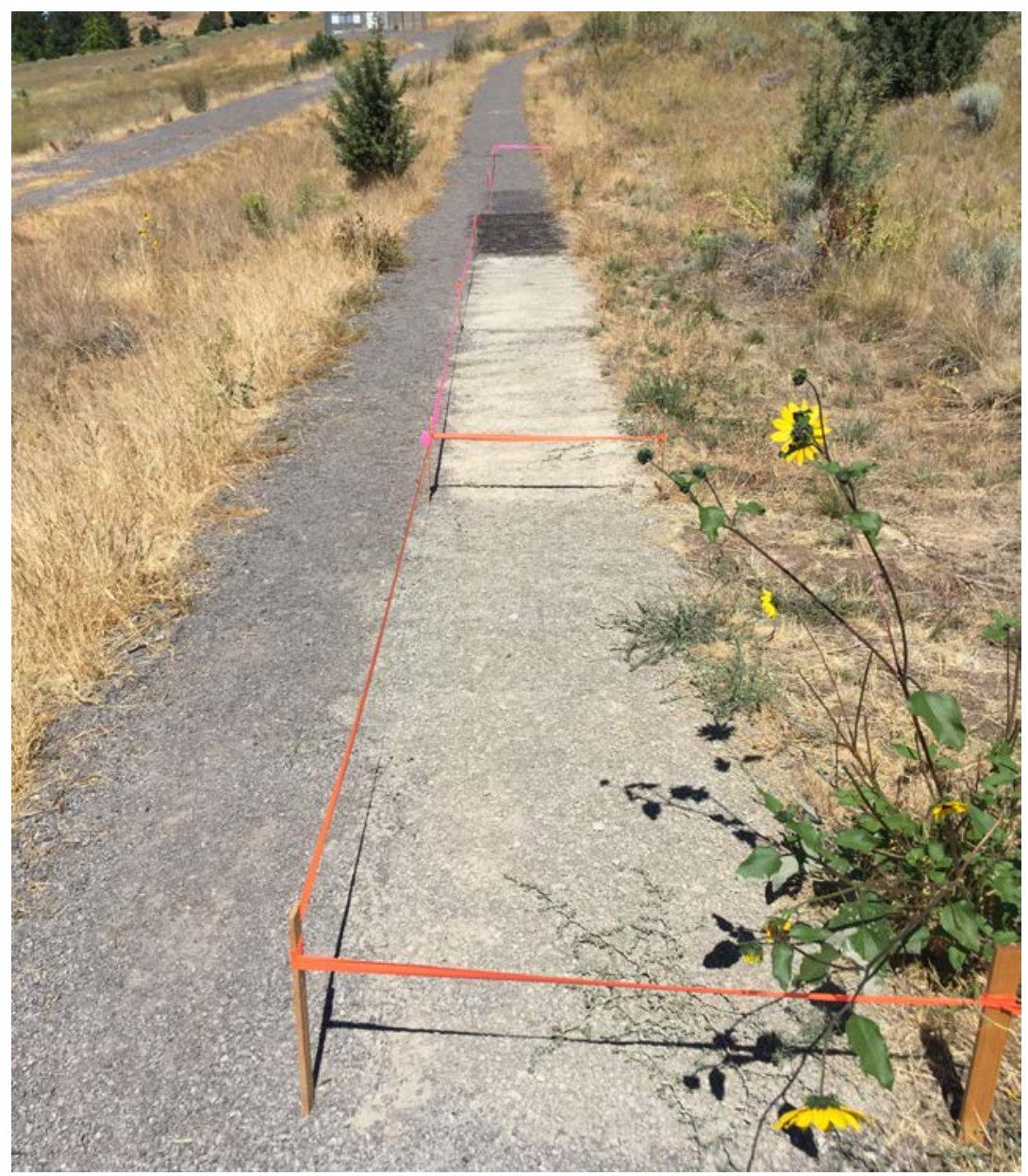

Figure 17 - Application of materials at the field site

Markers were placed along the geotrail creating six sections that are $91 \mathrm{~cm}$ wide by $3 \mathrm{~m}$ in length. Six more were created along the trail that maintained the $91 \mathrm{~cm}$ width, but the length was reduced to $150 \mathrm{~cm}$ when it was determined that space did not have a noticeable impact on the firmness or stability. Sections can be seen with the cementitious mixes applied, length of the section, and date of application in Table 15 . The cementitious mix applied was either $50 \%, 60 \%$ or $70 \%$ water with volcanic ash to portland cement ratios of $1.25,1.50$ and 1.75. For example, 70/175 in Table 15 would indicate $70 \%$ water, and 1.75 volcanic ash to portland cement ratio. Data sheets best describing the commercial binders are shown in the appendix Section 7.4 Marked sections were cordoned off for seven days after application to allow for curing. Preliminary firmness and 
stability readings were taken for each lot directly before being treated. Treatments were applied as volcanic ash was processed, or in the case of the SoilTac dilution, as data was made available to provide guidance.

Table 15. Information regarding the 12 sections used during field-scale firmness and stability testing

\begin{tabular}{|c|c|c|c|}
\hline $\begin{array}{c}\text { Section } \\
\text { Designation }\end{array}$ & $\begin{array}{c}\text { Cementitious Mix } \\
\text { Applied }\end{array}$ & $\begin{array}{c}\text { Length } \\
(\mathbf{m})\end{array}$ & $\begin{array}{c}\text { Date of } \\
\text { Application }\end{array}$ \\
\hline Lot 1 & $70 / 175$ & 3 & $8 / 13 / 2019$ \\
\hline Lot 2 & $50 / 175$ & 3 & $8 / 13 / 2019$ \\
\hline Lot 3 & $50 / 150$ & 3 & $8 / 13 / 2019$ \\
\hline Lot 4 & Klingstone Amber & 3 & $8 / 14 / 2019$ \\
\hline Lot 5 & G3 Soil Stabilizer & 3 & $8 / 14 / 2019$ \\
\hline Lot 6 & SoilTac 30\% Dilution & 3 & $9 / 5 / 2019$ \\
\hline Lot 7 & $50 / 125$ & 1.5 & $8 / 22 / 2019$ \\
\hline Lot 8 & $60 / 125$ & 1.5 & $8 / 27 / 2019$ \\
\hline Lot 9 & $60 / 150$ & 1.5 & $8 / 27 / 2019$ \\
\hline Lot 10 & $60 / 175$ & 1.5 & $8 / 27 / 2019$ \\
\hline Lot 11 & $70 / 125$ & 1.5 & $9 / 3 / 2019$ \\
\hline Lot 12 & $70 / 150$ & 1.5 & $9 / 3 / 2019$ \\
\hline
\end{tabular}

Sprayers were attempted for application of lots 1, 2, and 3 on July 2, 2019. Applications were not even and did not cover a third of the designated surface. Furthermore, it did not appear to greatly affect the firmness or stability of the full surface due to inadequate coverage. A more thorough application was done using a vessel designed to disperse water containing particulate over a wide area. The second application was applied to lots 1, 2, and 3 with the judgement that the existence of the prior application would not greatly affect results moving forward. Each cementitious mix, except for the commercial stabilizers, was weighed and mixed in a controlled environment, transported to the site, then agitated before application to ensure they were fully mixed. For the mix, $6[\mathrm{M} 2] .35 \mathrm{~kg}$ was determined for use as it maintains the same mix ratio per weight as used in the infiltration tests ( $5 \%$ by weight of gravel), under the assumption that the geotrail was only $2.5 \mathrm{~cm}$ of aggregate on top of packed soil. This assumption was created based on numerous site visits displaying a thin layer of loose gravel on top of packed soil. As field testing was carried out, it was revealed that what appeared to be packed soil was merely the fines of the trail having settled from use. Investigation confirmed prior grain size distributions were still accurate, even with this discovery.

Firmness and stability tests were conducted with the BDRP, similar to the lab-scale tests. Values were recorded on a weekly basis for 70 days after application, with readings being recorded the day of application before the mix was applied. Values were calculated for each trail section according to the process declared in the BDRP manual.

As demonstrated in the lab-scale testing, treatment improved the firmness and stability of the geotrail surface. Firmness does not appear to have improved noticeably, but when the change in 
firmness at weekly intervals compared proportionally with the pre-treatment firmness, it shows that surface firmness was improved by up to $27 \%$. A solitary reading for lot 8 shows an improvement of almost $40 \%$. For all sections except lots 8-10, sections treated with cementitious mixes that were $60 \%$ water, firmness appears to be affected more than stability, though not significantly. The reverse is true for section $1-3,7,11$, and 12 , where stability seems to be more affected by treatment than firmness, although still not significantly more. Section 4-6, which had commercial stabilizers applied to them, saw clear improvements to stability over firmness (Figure 18, Figure 19, Figure 20, Figure 21).

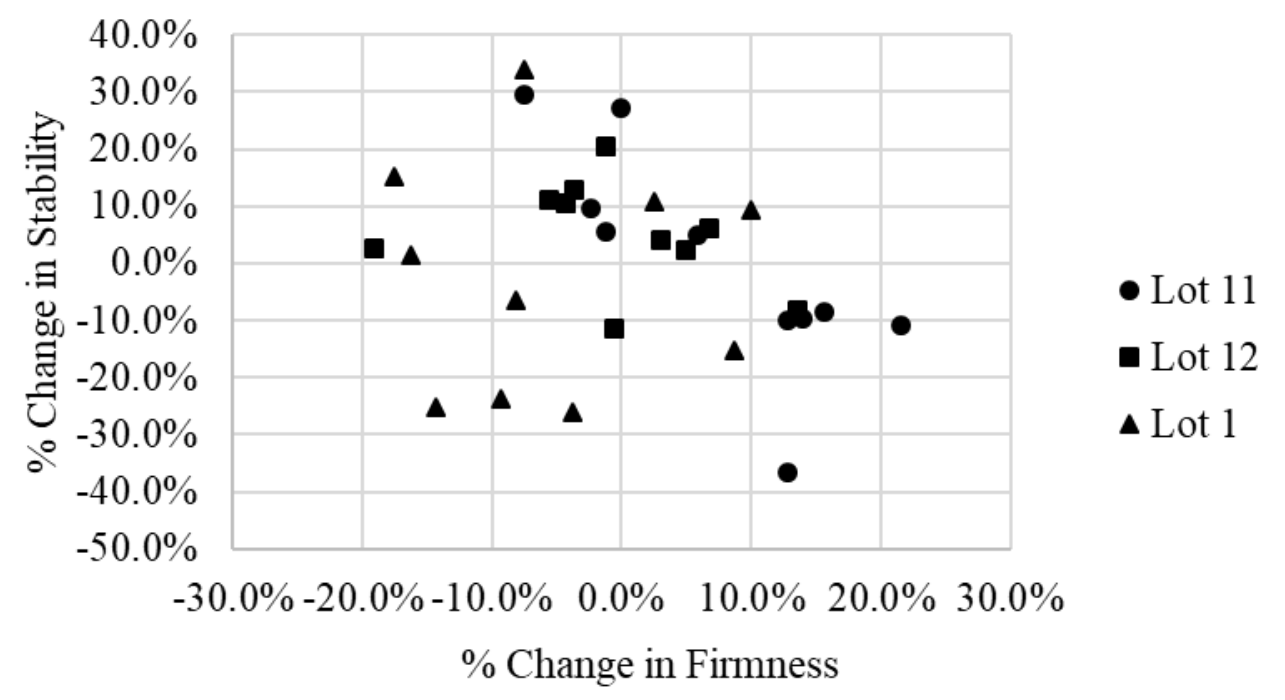

Figure 18 - Proportional change in surface characteristics for lots 11, 12, and 1 over 10 weeks of field-scale testing $-70 \%$ water mixes

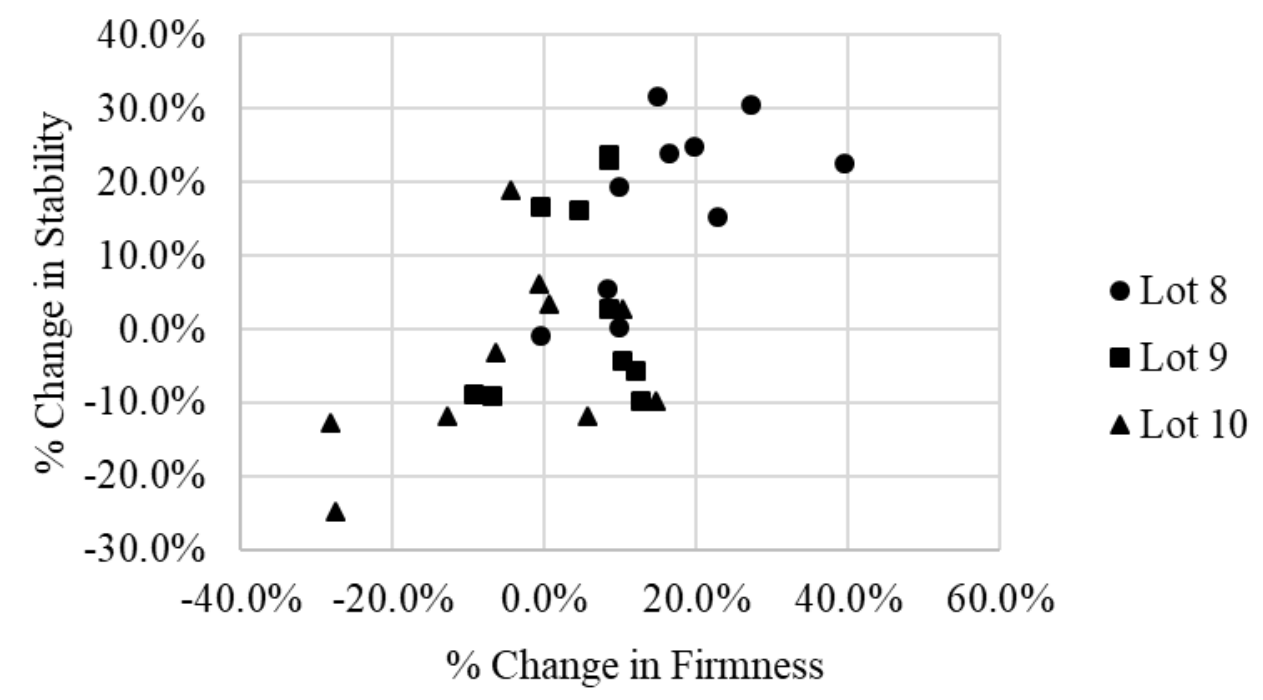

Figure 19 - Proportional change in surface characteristics for lots 8, 9, and 10 over 10 weeks of field-scale testing $-60 \%$ water mixes 


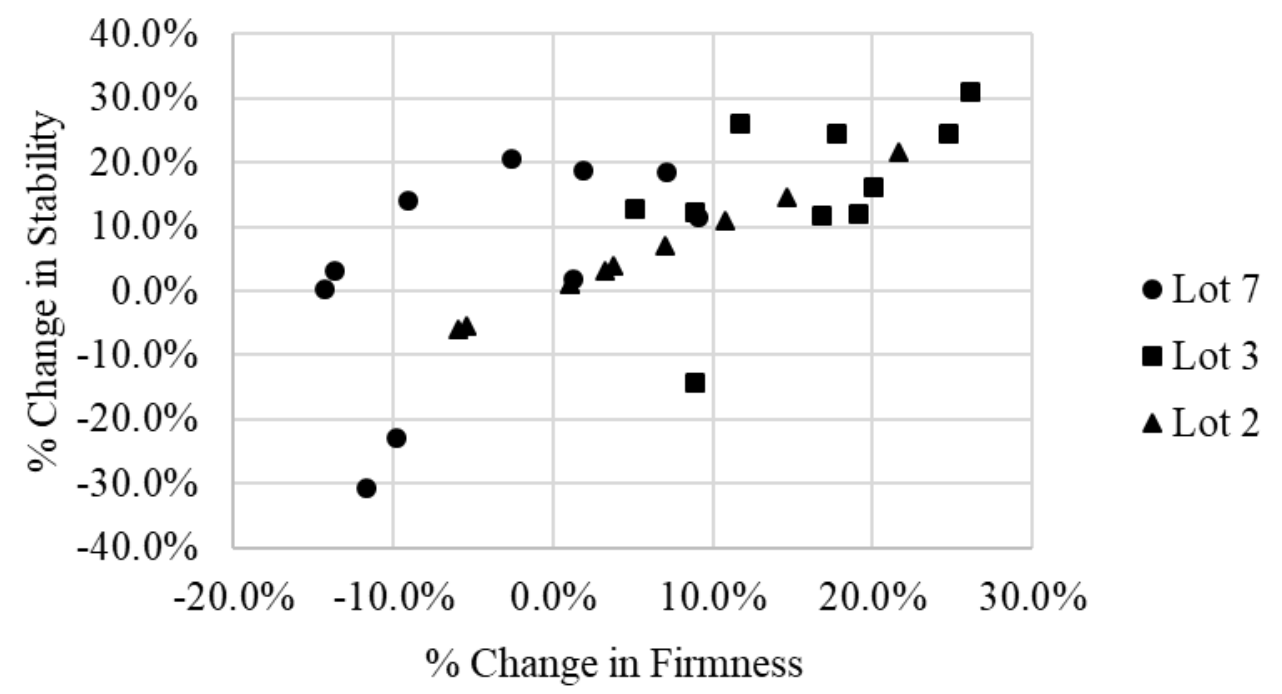

Figure 20 - Proportional change in surface characteristics for lots 7, 3, and 2 over 10 weeks of field-scale testing $-\mathbf{5 0 \%}$ water mixes

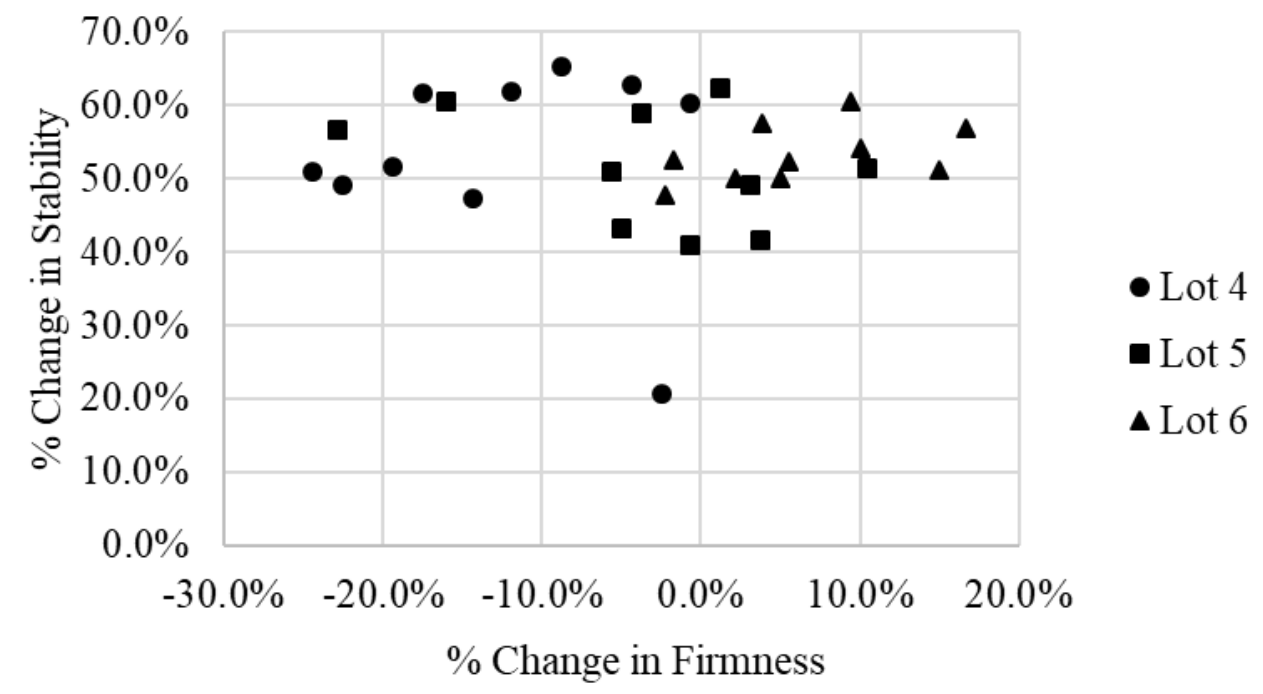

Figure 21 - Proportional change in surface characteristics for lots 4, 5, and 6 over 10 weeks of field-scale testing - commercial stabilizers

Every section treated with a non-commercial, cementitious mix saw both negative and positive changes to firmness and stability. Changes were considered mostly in relation to the pre-treated recorded characteristic for each section, and displayed as a percentage. Beneficial changes represent an increase in the surface firmness or stability, which would yield a lower reading with the BDRP. Non-beneficial changes were added to readings that showed no change from the base characteristic, as the goal of treatment is to improve the firmness and stability of the surface.

Commercial stabilizers provided no negative changes to stability, though negative changes to the surface firmness were recorded. Section 4, treated with Klingstone Amber polyurethane stabilizer, yielded no positive changes to surface firmness (Table 16) while increasing stability by an average of $53 \%$. This increase in stability is standard among the commercial stabilizers (Table 17). 
Table 16. Count of firmness and stability results that showed beneficial change or nonbeneficial change during field-scale firmness and stability testing

\begin{tabular}{|r|r|r|r|r|}
\hline \multicolumn{5}{|c|}{ Count of Changes to Surface Characteristics } \\
\hline \multirow{2}{*}{ Lot\# } & \multicolumn{2}{|c|}{ Firmness } & \multicolumn{2}{|c|}{ Stability } \\
\cline { 2 - 5 } & Non-Beneficial & Beneficial & Non-Beneficial & Beneficial \\
\hline 1 & 7 & 3 & 5 & 5 \\
\hline 2 & 2 & 8 & 2 & 8 \\
\hline 3 & 0 & 10 & 1 & 9 \\
\hline 4 & 10 & 0 & 0 & 10 \\
\hline 5 & 6 & 4 & 0 & 10 \\
\hline 6 & 2 & 8 & 0 & 10 \\
\hline 7 & 6 & 4 & 2 & 8 \\
\hline 8 & 1 & 9 & 1 & 9 \\
\hline 9 & 3 & 7 & 5 & 5 \\
\hline 10 & 6 & 4 & 6 & 4 \\
\hline 11 & 4 & 6 & 5 & 5 \\
\hline 12 & 6 & 4 & 2 & 8 \\
\hline Total & 53 & 67 & 29 & 91 \\
\hline
\end{tabular}

Table 17. Relative change in surface firmness and stability, averaged over 10 weeks

\begin{tabular}{|r|l|r|r|}
\hline \multicolumn{4}{|c|}{ Average Percent Increase after 70 Days } \\
\hline Lot\# & Mix designation & Firmness & \multicolumn{1}{l|}{ Stability } \\
\hline 1 & $70 / 175$ & $-5.6 \%$ & $-2.6 \%$ \\
\hline 2 & $50 / 175$ & $5.2 \%$ & $5.2 \%$ \\
\hline 3 & $50 / 150$ & $15.9 \%$ & $15.6 \%$ \\
\hline 4 & Klingstone & $-12.6 \%$ & $53.1 \%$ \\
\hline 5 & G3 & $-3.5 \%$ & $51.5 \%$ \\
\hline 6 & SoilTac & $6.4 \%$ & $53.3 \%$ \\
\hline 7 & $50 / 125$ & $-4.2 \%$ & $3.6 \%$ \\
\hline 8 & $60 / 125$ & $16.8 \%$ & $17.3 \%$ \\
\hline 9 & $60 / 150$ & $4.9 \%$ & $4.4 \%$ \\
\hline 10 & $60 / 175$ & $-4.9 \%$ & $-4.3 \%$ \\
\hline 11 & $70 / 125$ & $7.2 \%$ & $0.1 \%$ \\
\hline 12 & $70 / 150$ & $-0.6 \%$ & $5.1 \%$ \\
\hline
\end{tabular}

Current data suggests a trend toward lower water content mixtures, and lower ratios of volcanic ash to portland cement, yield higher quantity (Table 16) and quality (Table 17) changes to surface firmness and stability. Standing apart from this trend are lots 7, with regards to firmness, and lot 11, with regards to stability. Lot 7 was treated with a low water content and low volcanic ash ratio mixture, yet yielded non-beneficial changes to surface firmness. 
Variability in firmness and stability records were calculated for each set of measurements taken. Variability was calculated by finding the two standard deviations for the recorded data and dividing it by the calculated value for that set of data. This was done with the intent of determining whether treatment of the surface would bring the recorded values into a tighter grouping, meaning the calculated firmness and stability values would be more representative of the overall surface. Lower values for variability represent lower standard deviations, therefore the spread is reduced.

Every section demonstrated an increase in variability of firmness and stability except for lots 8 and 9. Lot 8 has a significant reduction in variability, though this is probably due to the unusually high variably of the surface before receiving treatment. Other pre-treatment variability for firmness readings are between $17 \%$ and 30\%, while the variability for lot 8 is $102 \%$ (Table 18). For stability, the range of variability is much larger, spanning from $15 \%$ to $74 \%$ (Table 19 ). Variability for both firmness and stability readings does not follow a predictable trend, and any effect of the treatment of the surface on variability would be negative. The improvement to variability in lot 9 is likely caused by the unpredictability of the variability for the data sets.

Table 18. Variation in surface firmness during field-scale firmness and stability testing per week

\begin{tabular}{|c|c|c|c|c|c|c|c|c|c|c|c|c|}
\hline \multicolumn{10}{|c|}{ Firmness Variation with Time } \\
\hline Days since treatment & Lot 1 & Lot 2 & Lot 3 & Lot 4 & Lot 5 & Lot 6 & Lot 7 & Lot 8 & Lot 9 & Lot 10 & Lot 11 & Lot 12 \\
\hline 0 & $17.0 \%$ & $25.0 \%$ & $23.0 \%$ & $51.0 \%$ & $29.0 \%$ & $42.0 \%$ & $28.0 \%$ & $102.0 \%$ & $17.0 \%$ & $27.0 \%$ & $26.0 \%$ & $30.0 \%$ \\
\hline 7 & $16.0 \%$ & $16.0 \%$ & $46.0 \%$ & $48.0 \%$ & $53.0 \%$ & $10.0 \%$ & $47.0 \%$ & $43.0 \%$ & $45.0 \%$ & $28.0 \%$ & $26.0 \%$ & $34.0 \%$ \\
\hline 14 & $31.0 \%$ & $34.0 \%$ & $20.0 \%$ & $30.0 \%$ & $38.0 \%$ & $18.2 \%$ & $16.0 \%$ & $35.0 \%$ & $21.0 \%$ & $28.0 \%$ & $10.5 \%$ & $8.9 \%$ \\
\hline 21 & $28.0 \%$ & $20.0 \%$ & $29.0 \%$ & $58.0 \%$ & $33.0 \%$ & $34.3 \%$ & $18.0 \%$ & $34.3 \%$ & $20.7 \%$ & $41.8 \%$ & $38.0 \%$ & $27.0 \%$ \\
\hline 28 & $21.0 \%$ & $32.0 \%$ & $12.0 \%$ & $21.0 \%$ & $47.0 \%$ & $18.8 \%$ & $29.4 \%$ & $27.2 \%$ & $15.3 \%$ & $38.0 \%$ & $22.3 \%$ & $35.9 \%$ \\
\hline 35 & $59.0 \%$ & $40.0 \%$ & $7.0 \%$ & $44.4 \%$ & $47.9 \%$ & $22.2 \%$ & $20.6 \%$ & $72.3 \%$ & $25.9 \%$ & $38.1 \%$ & $24.4 \%$ & $36.5 \%$ \\
\hline 42 & $9.0 \%$ & $20.0 \%$ & $26.0 \%$ & $33.0 \%$ & $22.6 \%$ & $44.2 \%$ & $20.9 \%$ & $15.7 \%$ & $72.4 \%$ & $21.6 \%$ & $53.2 \%$ & $32.1 \%$ \\
\hline 49 & $25.4 \%$ & $57.1 \%$ & $28.2 \%$ & $48.5 \%$ & $35.6 \%$ & $19.1 \%$ & $34.7 \%$ & $36.1 \%$ & $18.7 \%$ & $56.3 \%$ & $25.7 \%$ & $7.8 \%$ \\
\hline 56 & $23.5 \%$ & $27.1 \%$ & $26.8 \%$ & $39.4 \%$ & $44.0 \%$ & $15.0 \%$ & $46.8 \%$ & $23.3 \%$ & $36.4 \%$ & $20.6 \%$ & $32.0 \%$ & $52.7 \%$ \\
\hline 63 & $36.0 \%$ & $11.7 \%$ & $30.1 \%$ & $22.0 \%$ & $35.6 \%$ & $55.2 \%$ & $18.8 \%$ & $21.5 \%$ & $31.4 \%$ & $25.2 \%$ & $29.6 \%$ & $33.3 \%$ \\
\hline 70 & $62.6 \%$ & $28.9 \%$ & $27.0 \%$ & $7.8 \%$ & $34.4 \%$ & $49.7 \%$ & $34.0 \%$ & $20.4 \%$ & $21.4 \%$ & $34.5 \%$ & $20.0 \%$ & $36.0 \%$ \\
\hline
\end{tabular}


Table 19. Variation in surface stability during field-scale firmness and stability testing per week

\begin{tabular}{|c|c|c|c|c|c|c|c|c|c|c|c|c|}
\hline \multicolumn{13}{|c|}{ Stability Variation with Time } \\
\hline Days since treatment & Lot 1 & Lot 2 & Lot 3 & Lot 4 & Lot 5 & Lot 6 & Lot 7 & Lot 8 & Lot 9 & Lot 10 & Lot 11 & Lot 12 \\
\hline 0 & $38.0 \%$ & $15.0 \%$ & $25.0 \%$ & $21.0 \%$ & $18.0 \%$ & $20.0 \%$ & $28.0 \%$ & $42.0 \%$ & $74.0 \%$ & $27.0 \%$ & $36.0 \%$ & $74.0 \%$ \\
\hline 7 & $15.0 \%$ & $29.0 \%$ & $24.0 \%$ & $49.0 \%$ & $34.0 \%$ & $21.0 \%$ & $34.0 \%$ & $90.0 \%$ & $49.0 \%$ & $68.0 \%$ & $105.0 \%$ & $93.0 \%$ \\
\hline 14 & $24.0 \%$ & $60.0 \%$ & $77.0 \%$ & $26.0 \%$ & $32.0 \%$ & $29.4 \%$ & $24.0 \%$ & $71.0 \%$ & $116.0 \%$ & $46.0 \%$ & $95.2 \%$ & $58.9 \%$ \\
\hline 21 & $66.0 \%$ & $82.0 \%$ & $96.0 \%$ & $85.0 \%$ & $58.0 \%$ & $36.5 \%$ & $46.0 \%$ & $112.4 \%$ & $72.8 \%$ & $57.2 \%$ & $57.7 \%$ & $120.9 \%$ \\
\hline 28 & $47.0 \%$ & $99.0 \%$ & $178.0 \%$ & $92.0 \%$ & $59.0 \%$ & $33.3 \%$ & $31.6 \%$ & $75.4 \%$ & $100.5 \%$ & $69.6 \%$ & $60.8 \%$ & $84.7 \%$ \\
\hline 35 & $37.0 \%$ & $68.0 \%$ & $44.0 \%$ & $63.6 \%$ & $42.5 \%$ & $31.3 \%$ & $20.6 \%$ & $85.8 \%$ & $83.1 \%$ & $35.4 \%$ & $27.8 \%$ & $54.5 \%$ \\
\hline 42 & $62.0 \%$ & $145.0 \%$ & $34.0 \%$ & $98.5 \%$ & $36.3 \%$ & $40.1 \%$ & $31.8 \%$ & $53.3 \%$ & $82.5 \%$ & $43.2 \%$ & $52.2 \%$ & $85.4 \%$ \\
\hline 49 & $34.9 \%$ & $78.2 \%$ & $96.9 \%$ & $33.1 \%$ & $82.4 \%$ & $39.1 \%$ & $47.6 \%$ & $91.2 \%$ & $41.1 \%$ & $56.9 \%$ & $18.0 \%$ & $91.2 \%$ \\
\hline 56 & $58.3 \%$ & $38.3 \%$ & $132.1 \%$ & $45.2 \%$ & $59.0 \%$ & $14.8 \%$ & $65.3 \%$ & $60.3 \%$ & $75.4 \%$ & $51.0 \%$ & $28.4 \%$ & $91.2 \%$ \\
\hline 63 & $67.9 \%$ & $32.4 \%$ & $52.7 \%$ & $18.2 \%$ & $63.1 \%$ & $43.0 \%$ & $31.8 \%$ & $24.4 \%$ & $51.9 \%$ & $48.1 \%$ & $38.1 \%$ & $63.8 \%$ \\
\hline 70 & $32.7 \%$ & $93.5 \%$ & $86.0 \%$ & $91.2 \%$ & $23.3 \%$ & $34.7 \%$ & $27.5 \%$ & $53.9 \%$ & $41.7 \%$ & $34.9 \%$ & $30.7 \%$ & $40.1 \%$ \\
\hline
\end{tabular}

Surface firmness and stability show change with time. Firmness shows a constant positive trend, even though some are shown to have a non-beneficial change (Figure 22, Figure 23, Figure 24, Figure 25). Stability does not demonstrate any predictable or constant trend (Figure 26, Figure 27, Figure 28, Figure 29). Graphs pertaining to firmness and stability have been arranged so that similar mixes based on water content are displayed together to reduce clutter. It is also possible that the smaller non-beneficial changes are within error margins for an increase to that characteristic, as both characteristics do not display predictable behavior. However, more data is required before the full extent of the effectiveness can be determined.

Both firmness and stability were recorded for lots 1-12 for 70 days. Table 20 shows whether positive or negative changes in stability and firmness, on average, were recorded over the 70 days. As shown, all treated lots experienced an average increase in firmness over seven days. Interestingly, the change in firmness of the commercially treated lots were much less than the portland cement and volcanic ash treated lots. In terms of stability, positive and negative changes with time were experienced for the portland cement and volcanic ash treated lots. However, negative, or decreases, in stability with time were shown in the commercially treated lots. This indicates that the long-term gains in strength shown with the portland cement and volcanic ash mixes in the mortar cubes could be contributing to increases in firmness and stability with time. The commercially treated surfaces appear to be degrading in stability with time in contrast to the portland cement and volcanic ash treated surfaces. 
Table 20. Averaged change in stability and firmness over $\mathbf{7 0}$ days for all treated lots

\begin{tabular}{|c|c|c|c|c|}
\hline Lot \# & Stability & $\begin{array}{c}\text { Correlation } \\
\text { Coefficient }\end{array}$ & Firmness & $\begin{array}{c}\text { Correlation } \\
\text { Coefficient }\end{array}$ \\
\hline 1 & + & 0.0003 & + & 0.0002 \\
\hline 2 & + & 0.003 & + & 0.0004 \\
\hline 3 & + & 0.001 & + & 0.0005 \\
\hline 4 & - & -0.001 & + & 0.00007 \\
\hline 5 & - & -0.0017 & + & 0.0002 \\
\hline 6 & - & -0.0008 & + & 0.00004 \\
\hline 7 & + & 0.0025 & + & 0.0007 \\
\hline 8 & + & 0.0022 & + & 0.0005 \\
\hline 9 & - & -0.0003 & + & 0.0004 \\
\hline 10 & + & 0.0011 & + & 0.0009 \\
\hline 11 & - & -0.0002 & + & 0.0003 \\
\hline 12 & - & -0.0018 & + & 0.0004 \\
\hline
\end{tabular}

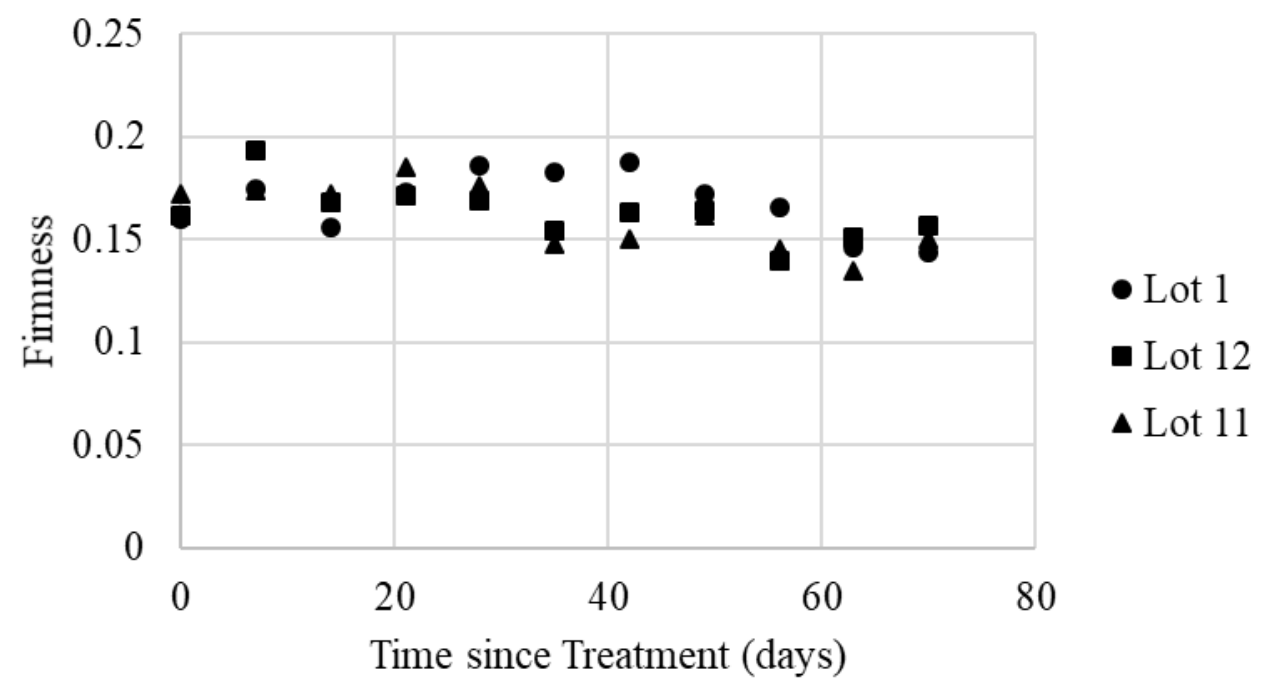

Figure 22 - Firmness of lots 1, 12, and 11 with time during field-scale firmness and stability testing 


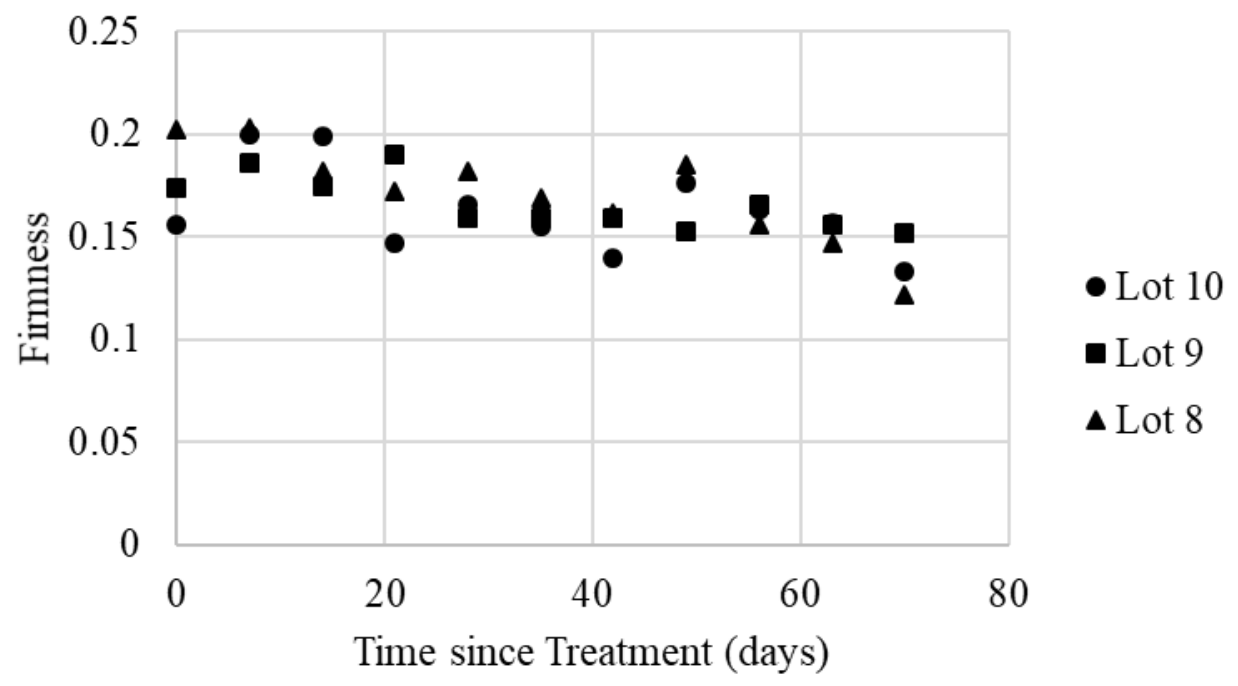

Figure 23 - Firmness of lots 10, 9, and 8 with time during field-scale firmness and stability testing

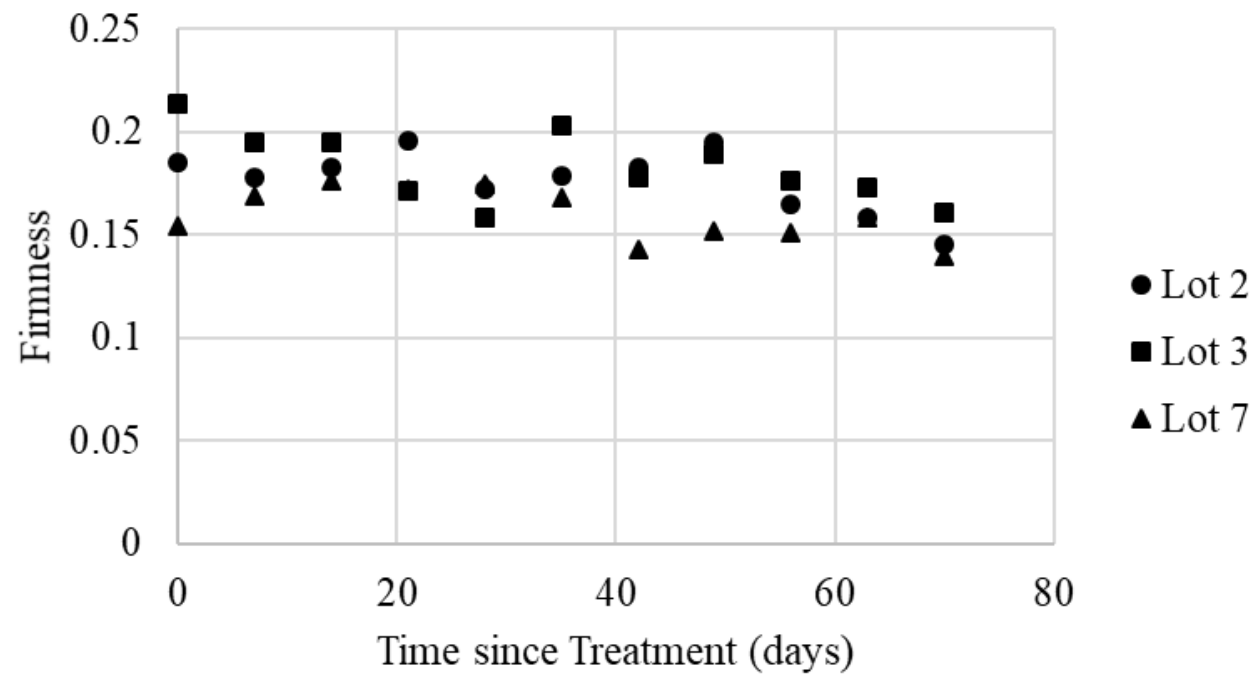

Figure 24 - Firmness of lots 2, 3, and 7 with time during field-scale firmness and stability testing 


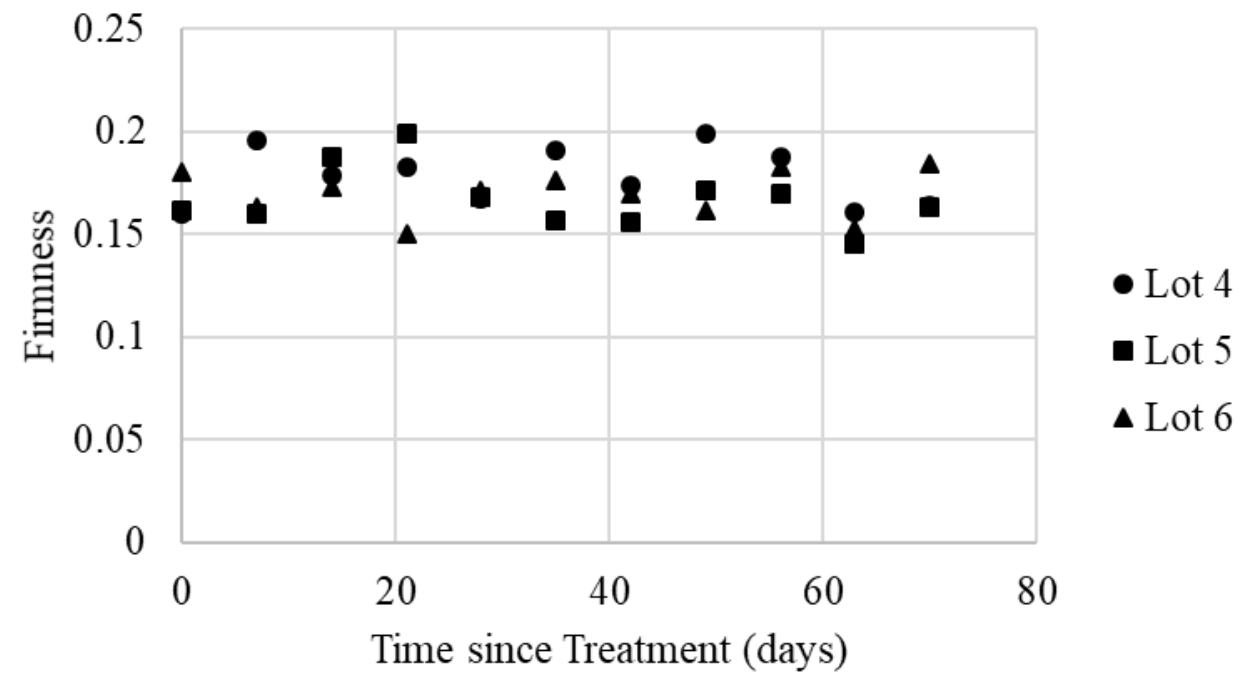

Figure 25 - Firmness of lots 4, 5, and 6 with time during field-scale firmness and stability testing

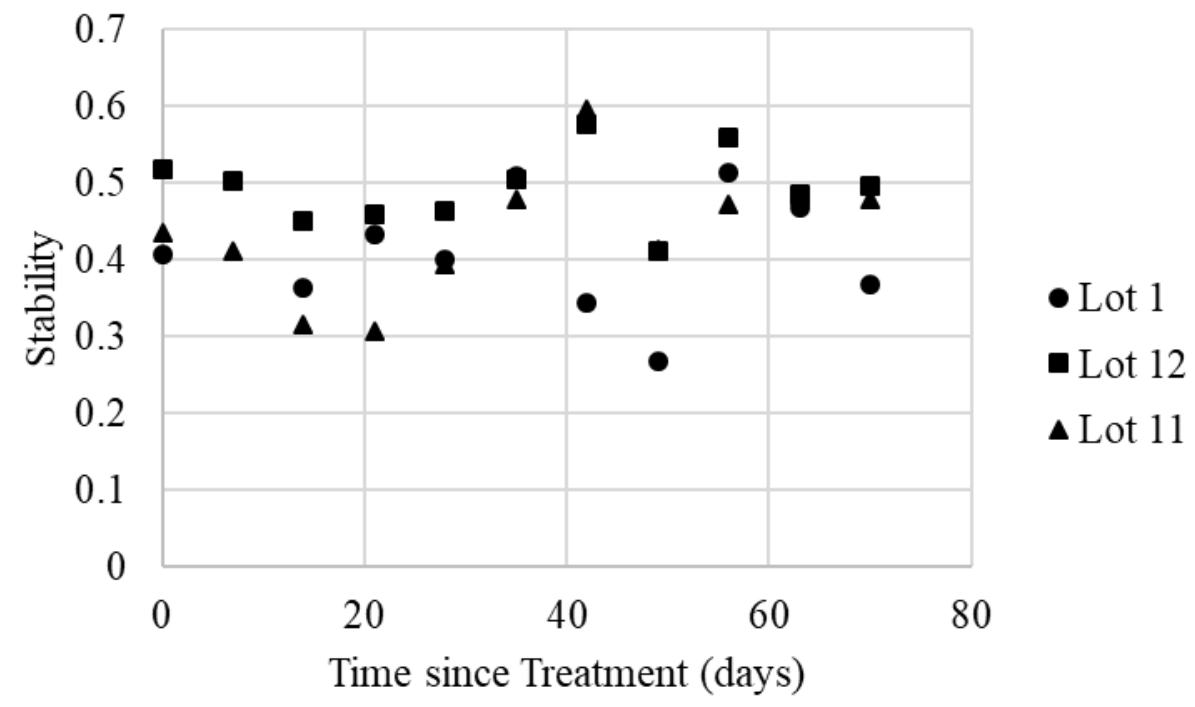

Figure 26 - Stability of lots 1, 12, and 11 with time during field-scale firmness and stability testing 


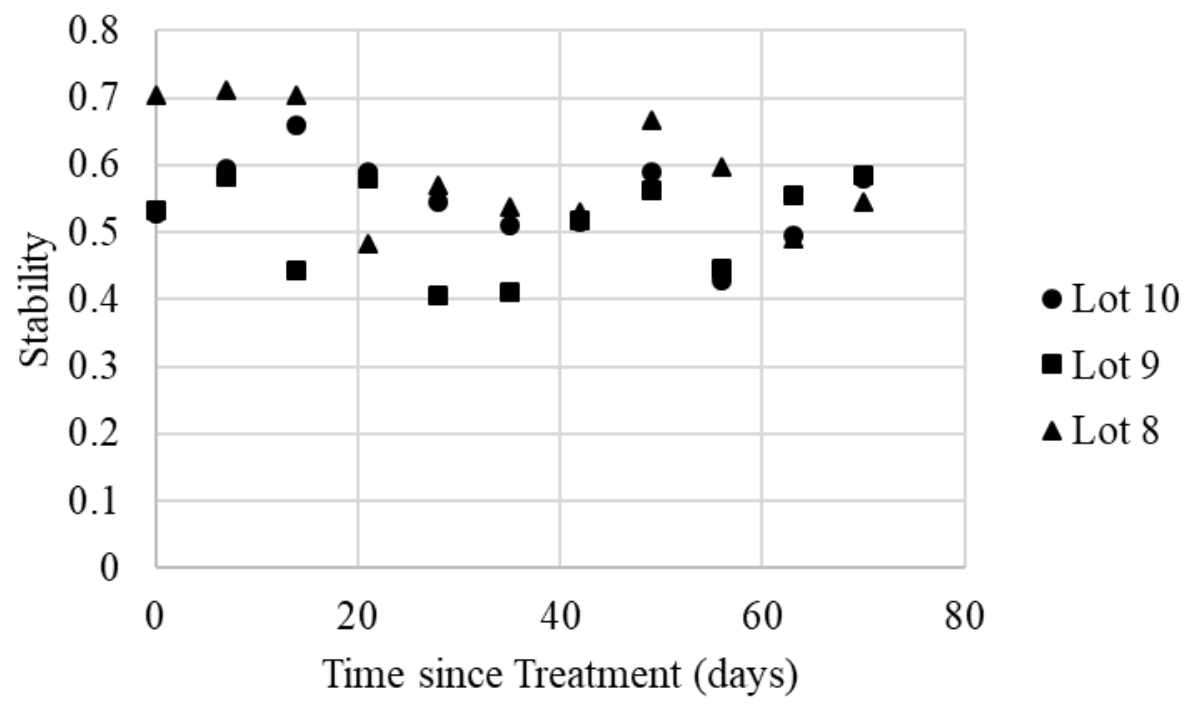

Figure 27 - Stability of lots 10, 9, and 8 with time during field-scale firmness and stability testing

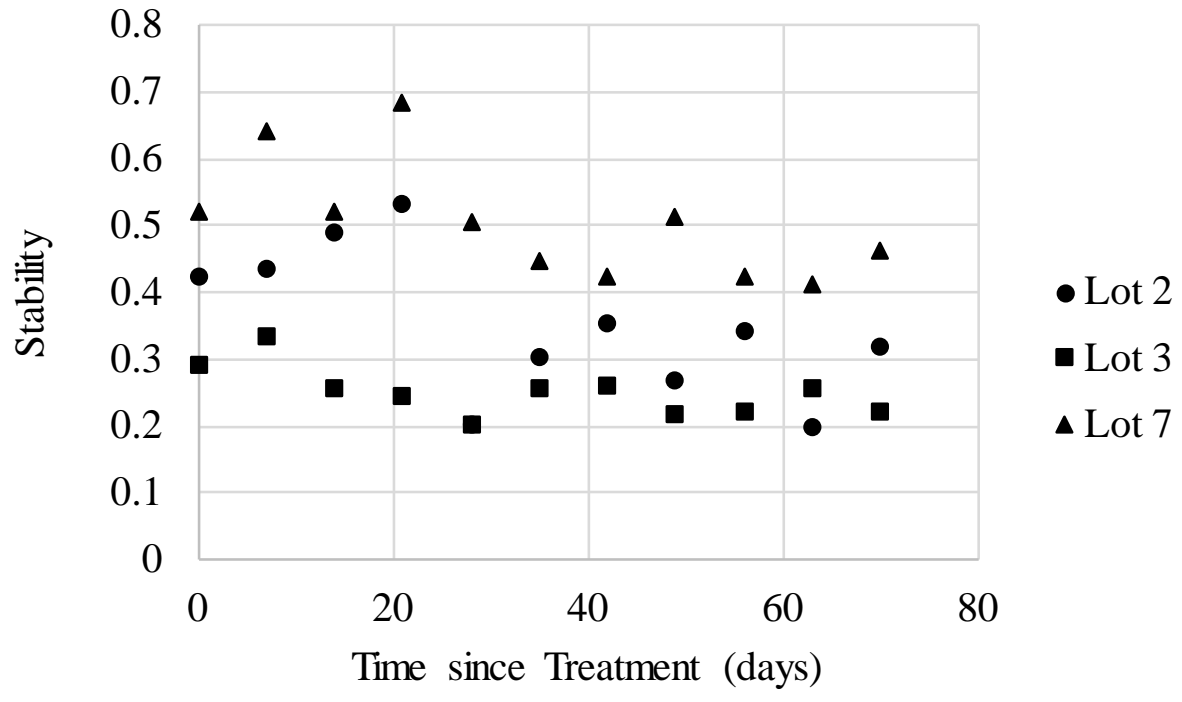

Figure 28 - Stability of lots 2, 3, and 7 with time during field-scale firmness and stability testing 


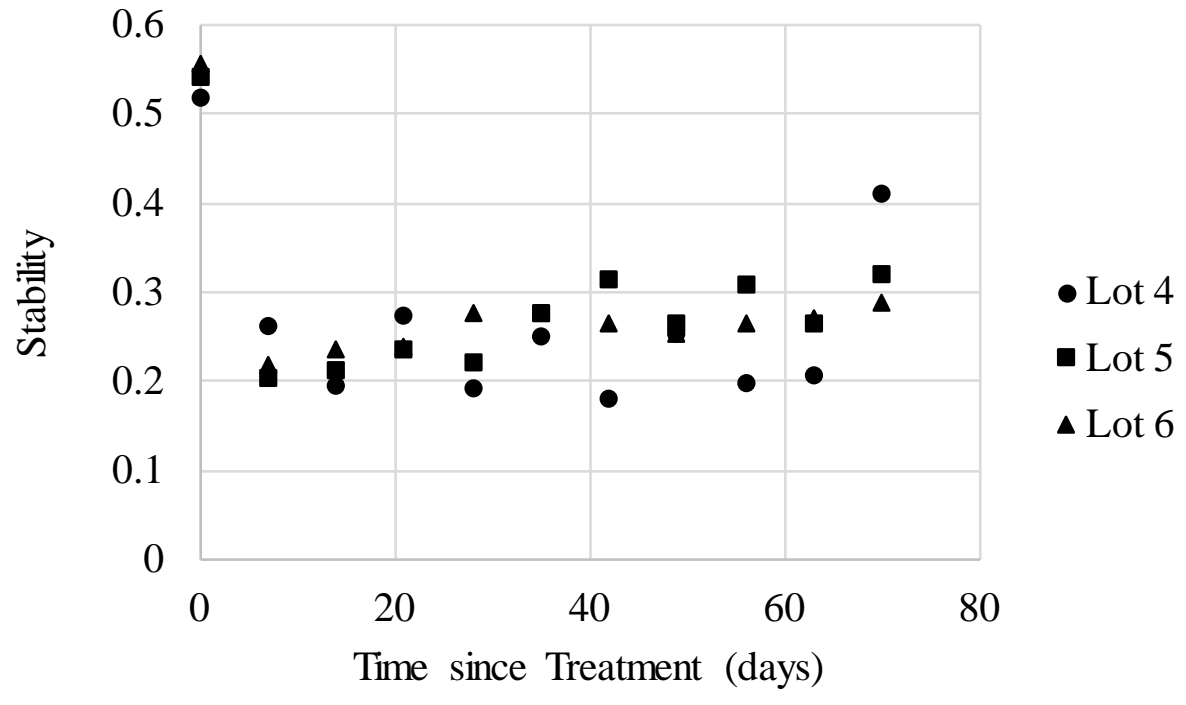

Figure 29 - Stability of lots 4, 5, and 6 with time during field-scale firmness and stability testing. 


\subsection{DATA INTERPRETATION AND CORRELATIONS}

As discussed previously, this study has included an extensive gathering of data related to the use of a natural pozzolan for binding unpaved surfaces. Unpaved surfaces can be used as ADA accessible trails if the surface is firm and stable. Because there is an infinite combination of gravel surfaces, with different gradations and pozzolanic and cementitious materials, the data collected has been reviewed for trends and correlations. These trends and correlations can be used to transform the materials studied here to other materials and locations.

\subsubsection{Compressive Strength and Ratio of Volcanic Ash to Portland Cement}

For this work, over 175 mortar cubes were created with different percentages of volcanic ash and portland cement along with water and graded sand following ASTM C109. An attempt was made to understand the relationship between increasing the replacement percentage of portland cement with volcanic ash. These data relationships are shown in Figure 30, Figure 31, Figure 32, Figure 33, Figure 34, Figure 35, Figure 36 and Figure 37. A table of results is shown in Table 21. A second-order polynomial can be used to describe the relationship between strength and ash to portland ratio for sample ages from 7 to 84 days with high reliability. These presented equations can aid engineers and designers when attempting to determine the effects on strength of reducing portland cement and substituting processed, volcanic ash used in this study.

Table 21. Compressive strength of mortar cubes with increasing ratios of volcanic ash to portland cement (strength in psi)

\begin{tabular}{|c|c|c|c|c|c|c|c|}
\hline \multirow{2}{*}{$\begin{array}{c}\text { Ratio of Volcanic Ash } \\
\text { to Portland Cement }\end{array}$} & \multicolumn{7}{|c|}{ Age (days) } \\
\hline & 7 & 21 & 28 & 42 & 56 & 70 & 84 \\
\hline $0 \%$ & 5744 & 6335 & 6631 & 6980 & 6980 & 6980 & 6980 \\
\hline $25 \%$ & 3856 & 4274 & 4483 & 4933 & 5168 & 5241 & 5289 \\
\hline $43 \%$ & 2629 & 2844 & 2952 & 3155 & 3183 & 3496 & 3808 \\
\hline $67 \%$ & 1583 & 1839 & 1967 & 2148 & 2218 & 2481 & 2543 \\
\hline $150 \%$ & 65 & 103 & 123 & 130 & 138 & 148 & 158 \\
\hline
\end{tabular}

Few studies were found that used processed, volcanic ash with similar chemical composition to that of Mt. Mazama volcanic ash to replace portland cement. One such study, by Hossain and Lachemi (2006), used a similar volcanic ash from Papua New Guinea (Table 22). Chemically, the material is nearly the same as Mt. Mazama volcanic ash however fineness of the material is appreciably higher for the Papua New Guinea volcanic ash. As with our study, Hossain and Lachemi prepared mortar cubes with increasing replacement of portland cement with volcanic ash. The strength of their cubes was compared to a control sample that had the same water to cement ratio as this study. As can be observed in Figure 36, the strength loss in samples with up to approximately $25 \%$ replacement with volcanic ash had nearly the same loss in strength between the two studies. As percentages of replacement increase beyond 25\%, the two studies 
diverge with higher strength reported in this study. It is hypothesized that this may be due to the decrease in fineness of the materials used in this study. When fineness is decreased, pozzolanic reactivity is delayed. However this does not fully explain the large overall higher strengths observed in this study.

Table 22. Comparison of chemical composition and fineness between Mt. Mazama volcanic ash and that studied by Hossain and Lachemi (2006)

\begin{tabular}{|c|c|c|c|}
\hline Compound & Mt. Mazama Ash (\%) & Hossain and Lachemi 2006 (\%) & Difference(\%) \\
\hline $\mathrm{SiO}_{2}$ & 65.81 & 59.32 & 6.49 \\
\hline $\mathrm{Al}_{2} \mathrm{O}_{3}$ & 18.75 & 17.54 & 1.21 \\
\hline $\mathrm{Fe}_{2} \mathrm{O}_{3}$ & 4.40 & 7.06 & 2.66 \\
\hline $\mathrm{CaO}$ & 3.42 & 6.10 & 2.68 \\
\hline $\mathrm{MgO}$ & 1.45 & 2.55 & 1.10 \\
\hline $\mathrm{SO}_{3}$ & -0.01 & 0.71 & 0.72 \\
\hline $\mathrm{Na}_{2} \mathrm{O}$ & 3.20 & 3.80 & 0.60 \\
\hline $\mathrm{K}_{2} \mathrm{O}$ & 1.98 & 2.03 & 0.05 \\
\hline Retained on $\mathrm{No} .325$ Sieve (\%) & 44 & 12 & 32 \\
\hline
\end{tabular}

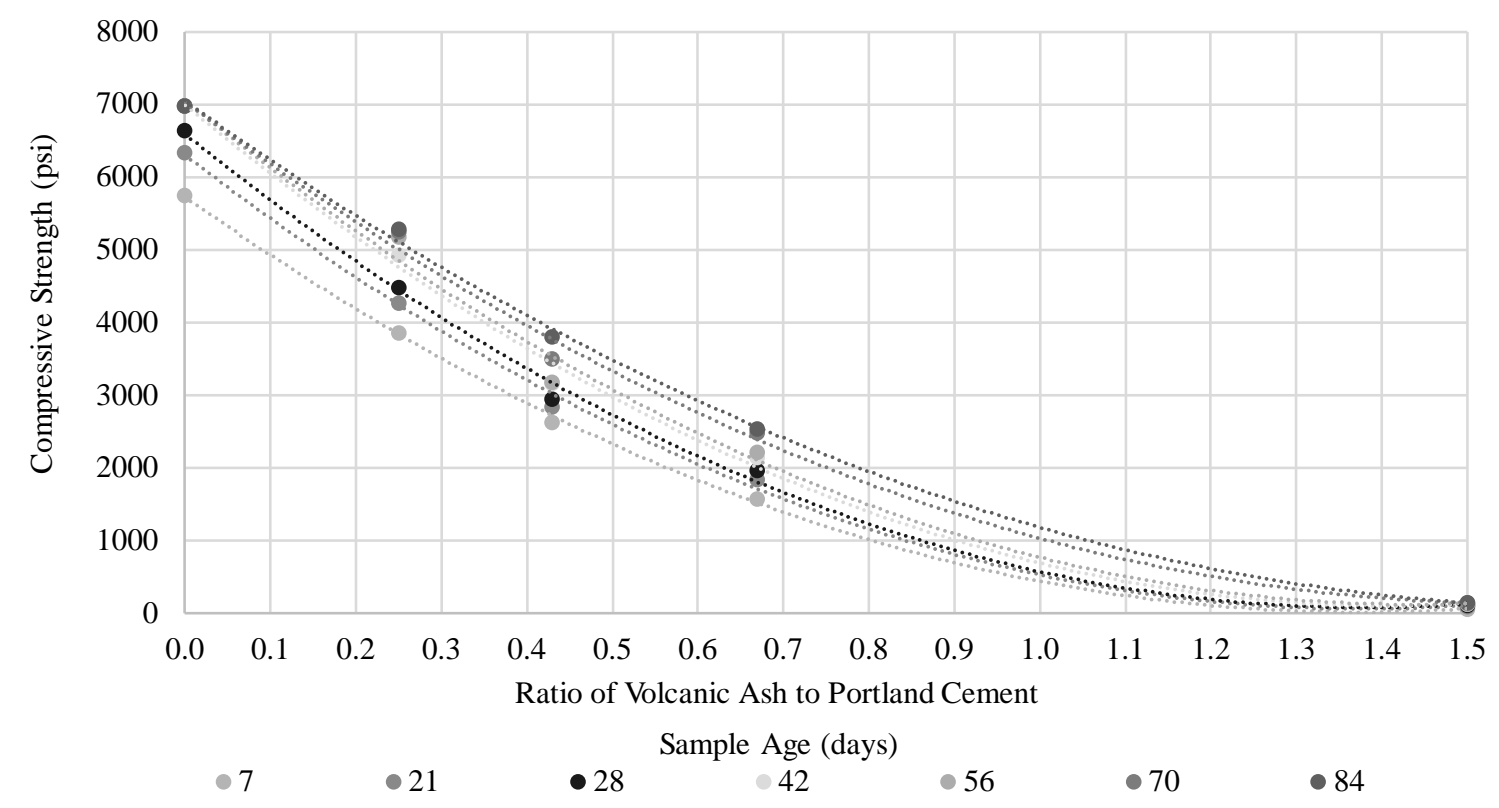

Figure 30 - The comparison between the compressive strength for each testing time period compared to the ratio of volcanic ash to portland cement 


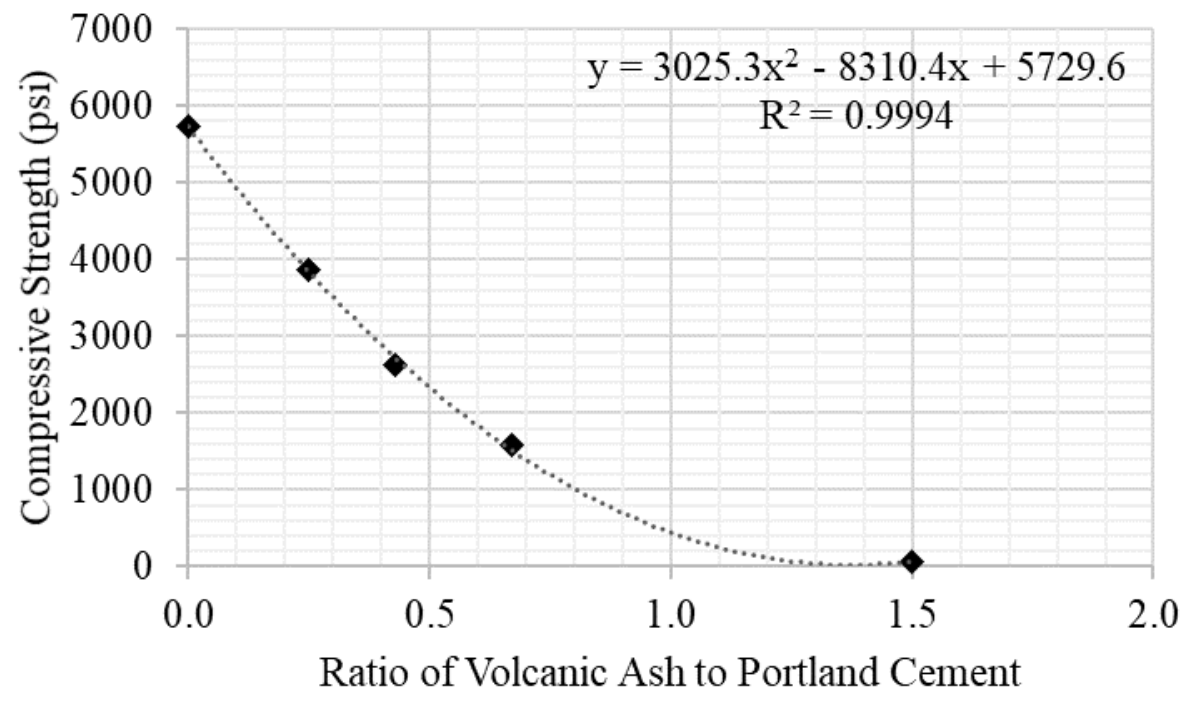

Figure 31 - Compressive strength and ratio of volcanic ash to portland cement (seven-day cure time)

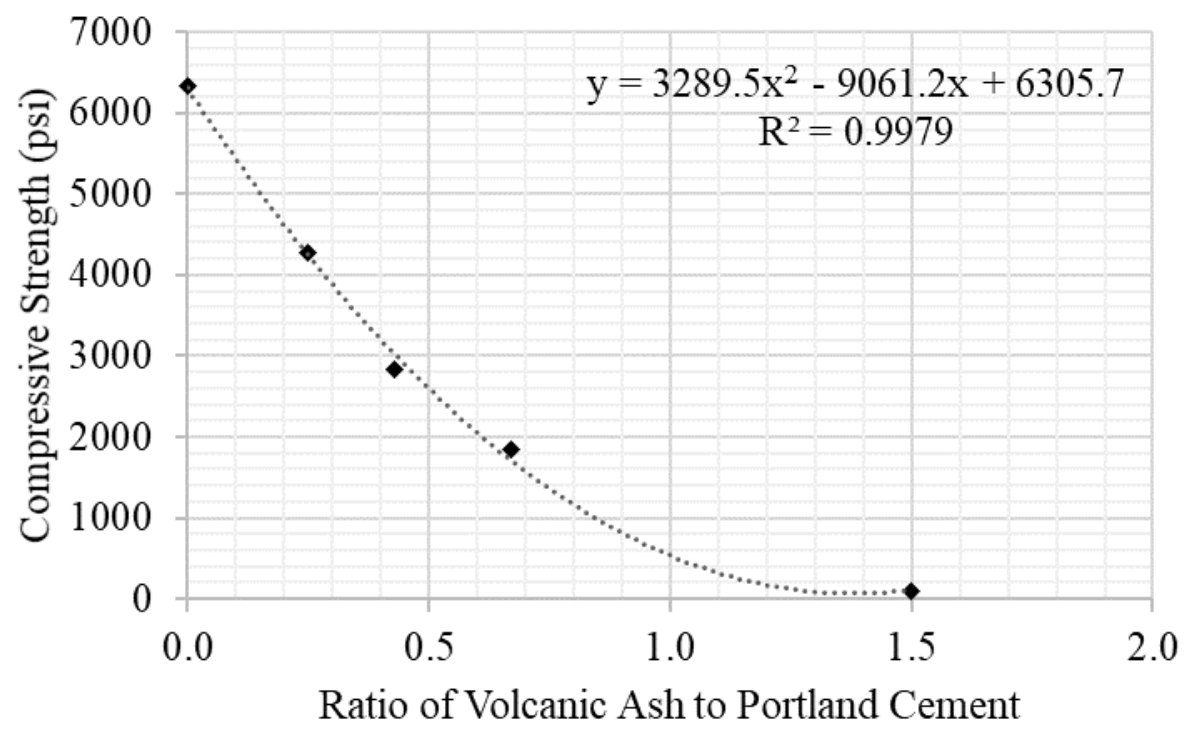

Figure 32 - Compressive strength and ratio of volcanic ash to portland cement (21-day cure time) 


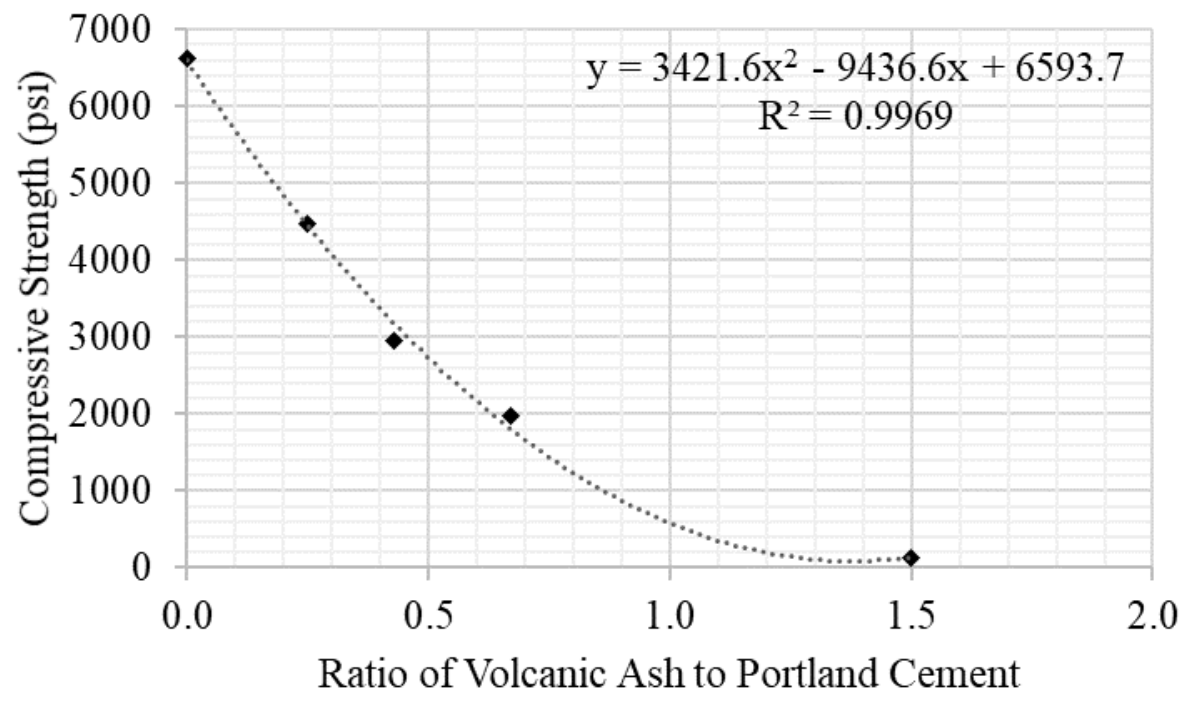

Figure 33 - Compressive strength and ratio of volcanic ash to portland cement (28-day cure time)

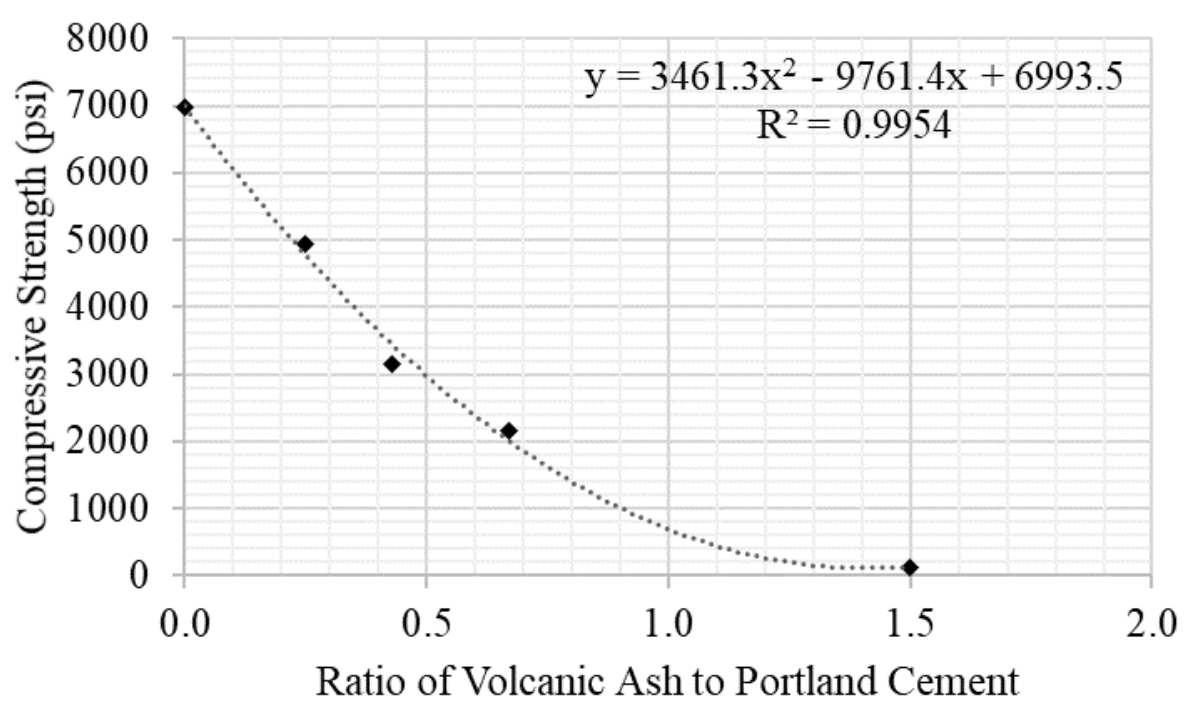

Figure 34 - Compressive strength and ratio of volcanic ash to portland cement (42day cure time) 


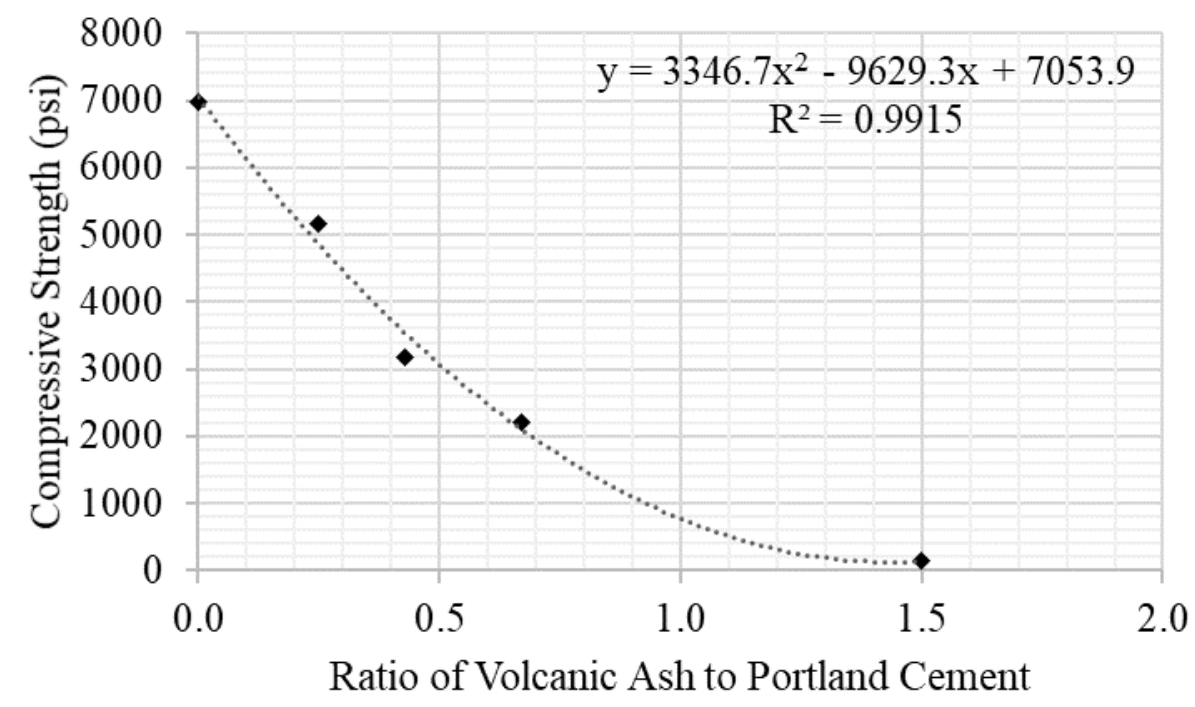

Figure 35 - Compressive strength and ratio of volcanic ash to portland cement (56-day cure time)

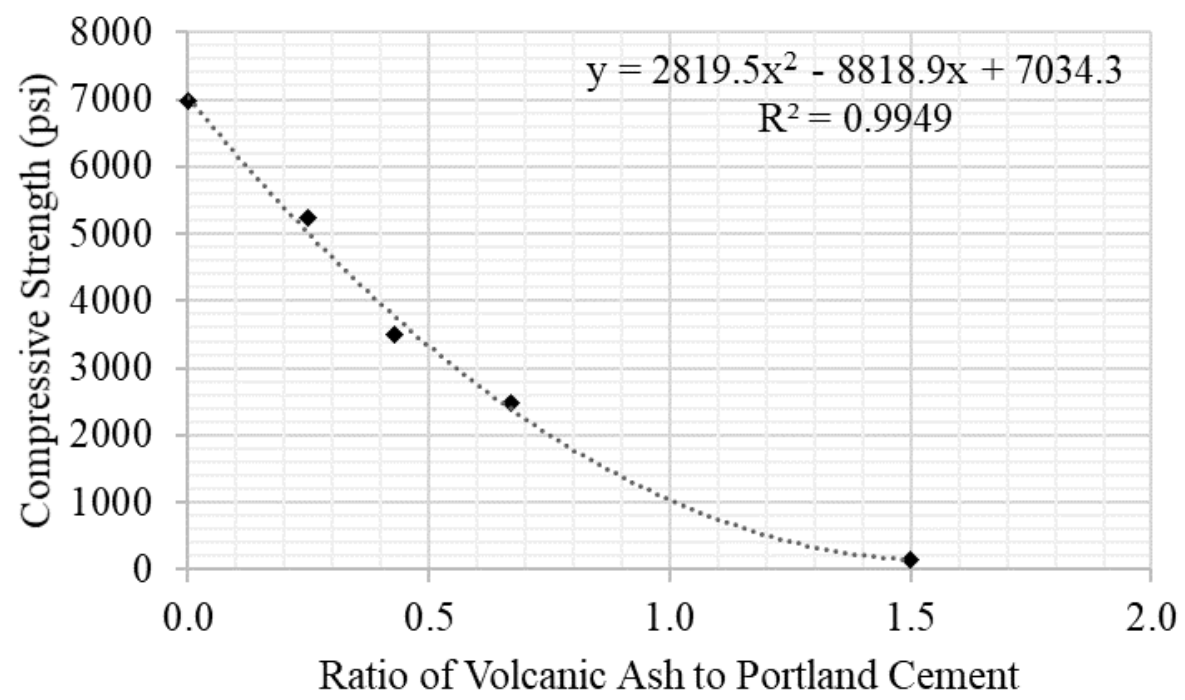

Figure 36 - Compressive strength and ratio of volcanic ash to portland cement (70-day cure time) 


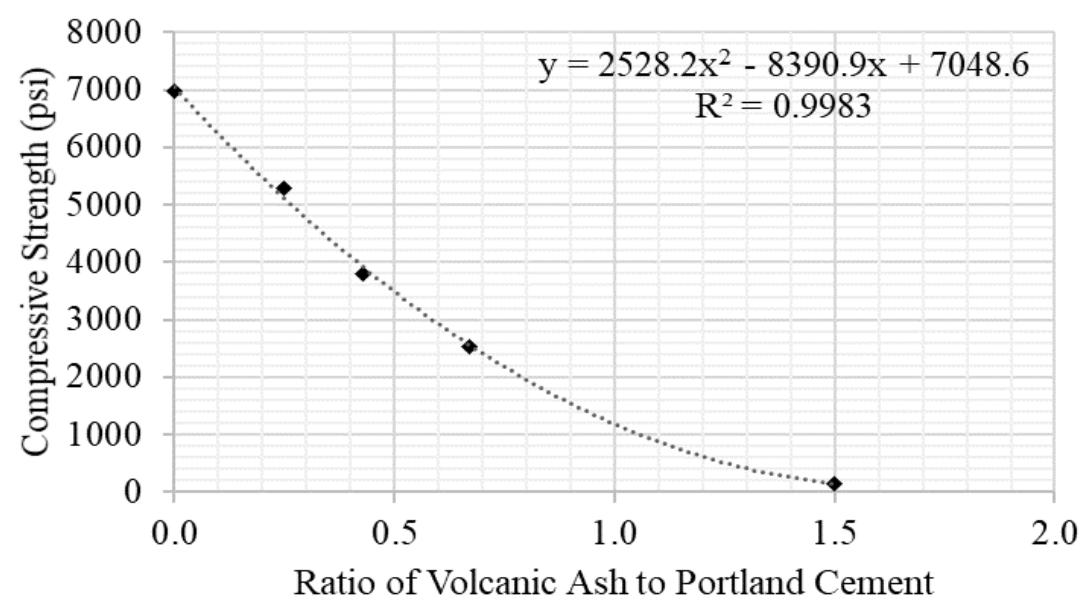

Figure 37 - Compressive strength and ratio of volcanic ash to portland cement (84-day cure time)
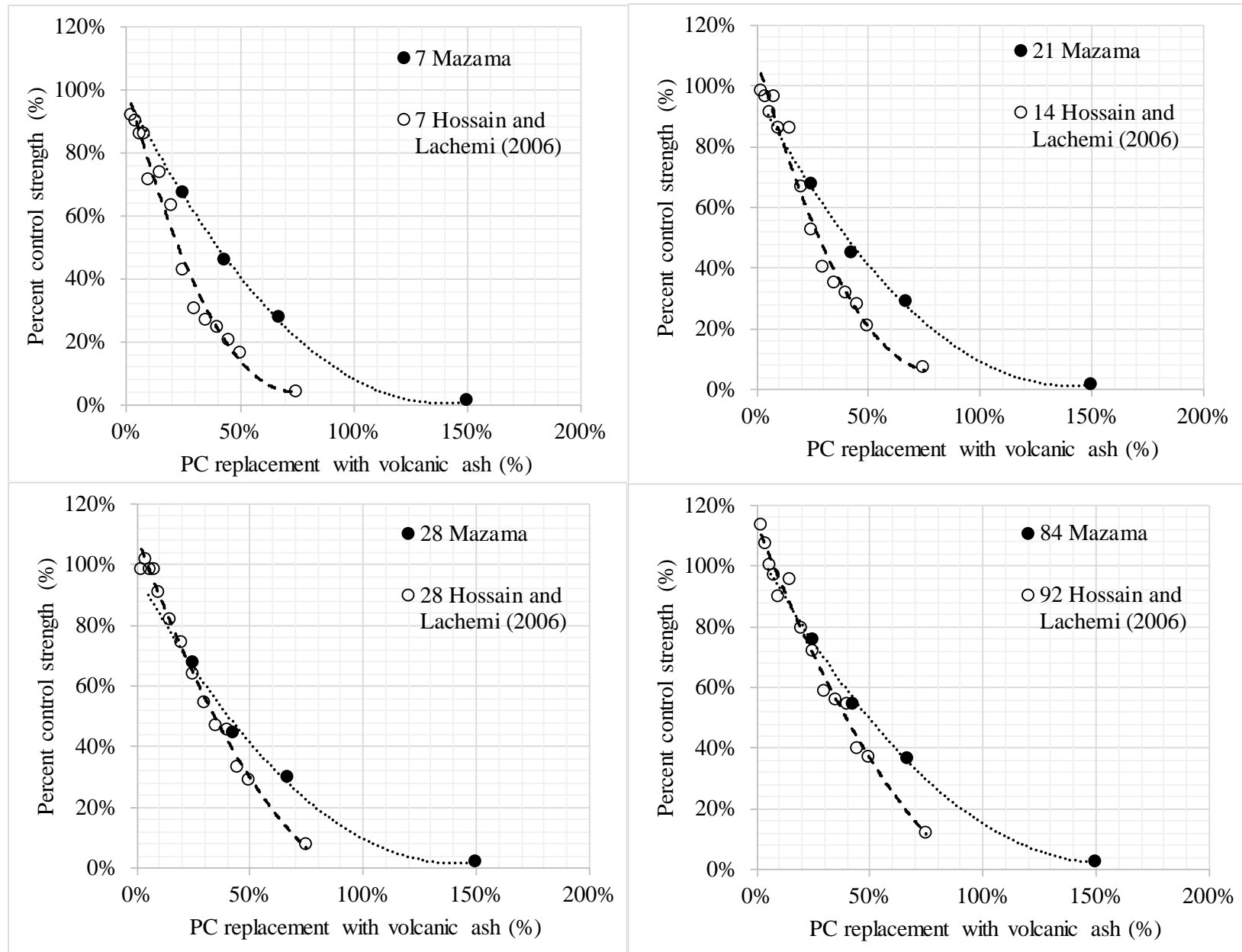

Figure 38 - Comparison of unconfined compressive strength for mortar cubes made with increasing replacement of portland cement with volcanic ash - 1, 2, 4, and 7 week curing times 


\subsubsection{Firmness and Stability}

The BDRP takes measurements of firmness and stability as discussed in a previous section of the report. Prior to this research, it was anticipated that a strong, positive correlation would exist between the firmness and stability of an unpaved trail surface. For this study, 190 separate locations were taken of firmness and stability using the BDRP. At each location, there are seven measurements taken resulting in 1,330 separate measurements of firmness and 1,330 measurements of stability. As shown in Figure 39, while the trend is positive, the variability between firmness and stability is large. It is not accurate to assume that increases or decreases to firmness and stability occur concurrently. When separated into treated surfaces and untreated surfaces, Figure 40 and Figure 41, it appears that untreated surfaces are modeled better with a linear relationship than treated surfaces. This may indicate that treatment affects stability or firmness independently. Figure 41 appears to show a gap in measured data between stability measurements of 1.0 to 1.4. This data 'gap' is a result of testing untreated surfaces with relatively small (<1/4”) and relatively large ( $>3 / 4$ ”) material. When the material is not bound with an admixture, the stability and firmness of the material is largely influence by the size of the material as individual pieces of loose aggregate are moved by the wheel of the BDRP.

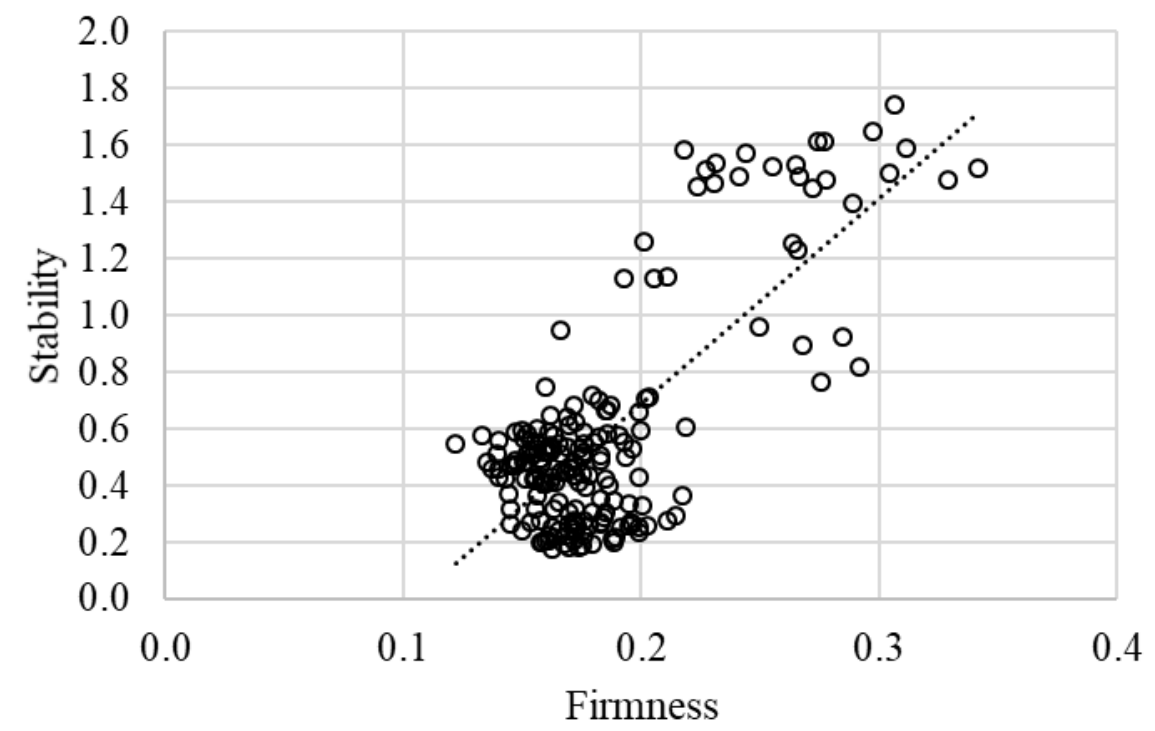

Figure 39 - Measured values of firmness and stability with the BDRP as part of this study 


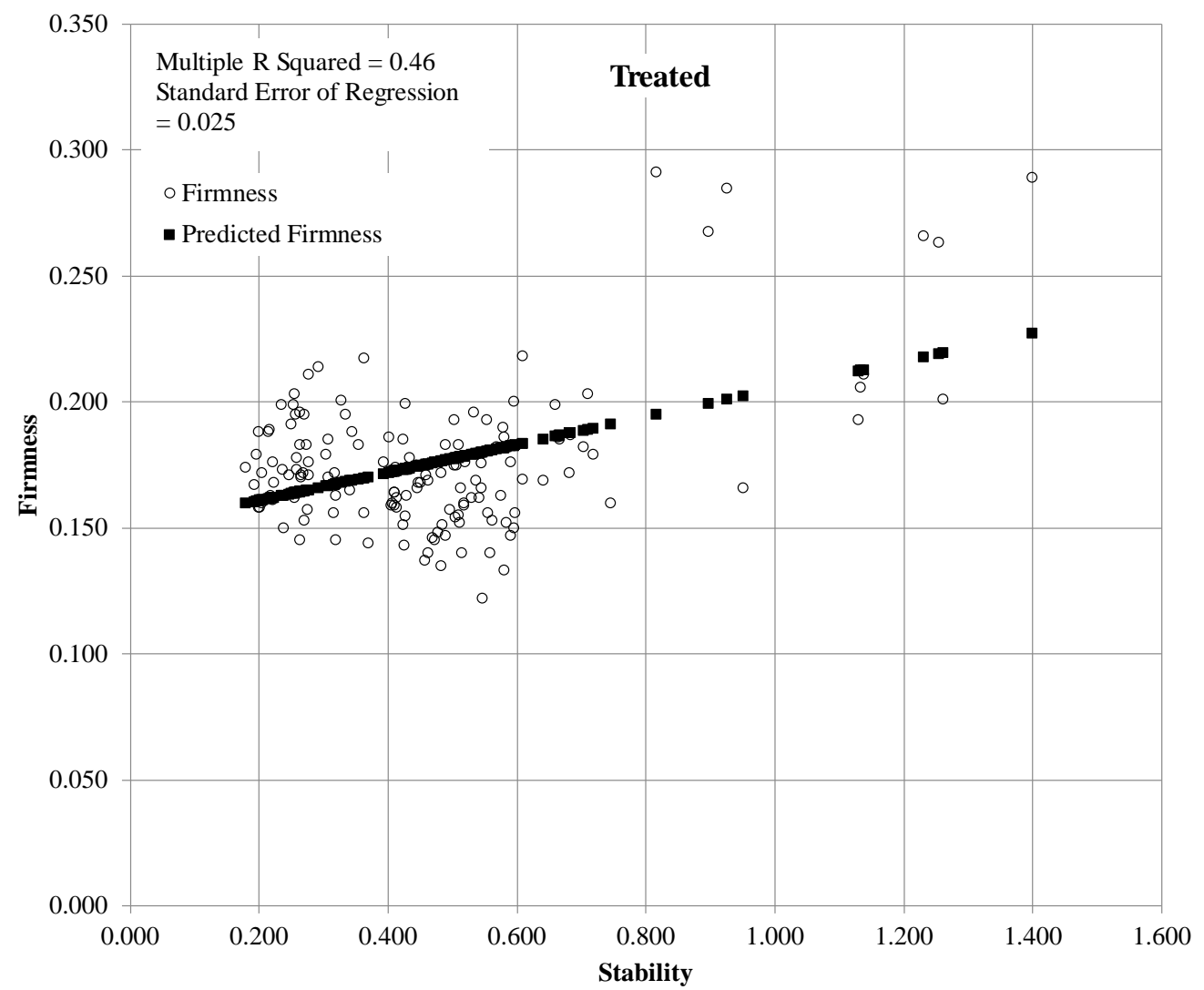

Figure 40 - Linear regression of firmness and stability for all treated surfaces 


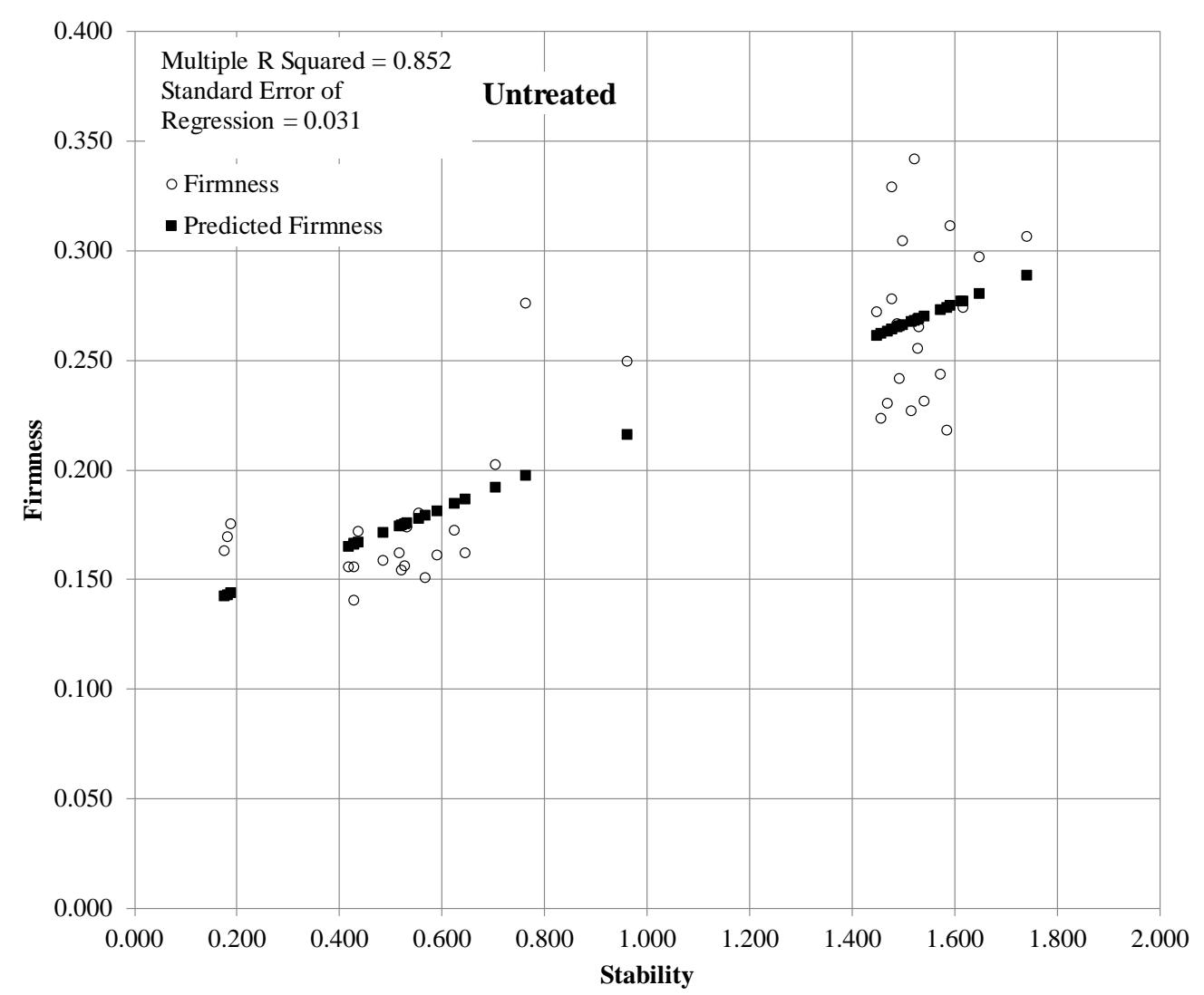

Figure 41 - Linear regression of firmness and stability for all untreated surfaces

\subsubsection{Correlations between Pour Tests and Gravel Gradations}

The pour tests used for this study attempted to determine proportions of water, portland cement and volcanic ash that could bind and penetrate gravel. The goal is to bind and penetrate unpaved trail surfaces (gravel) to the largest extent possible to increase firmness and stability. As with the compressive strength of mortar cubes from his study, there is an infinite combination of gradations, water, portland cement and volcanic ash that could be studied. With hopes that the information contained in this report can be translated to different locations with different gravel properties, a comprehensive review of the pour test data was conducted.

It is hypothesized that infiltration depth and percentage bound material are a function of slurry viscosity and permeability of the gravel material. Permeability is mostly controlled by the $\mathrm{D}_{10}$ size of a gravel as indicated in Duncan (2008). In addition to $\mathrm{D}_{10}$, the influence of $\mathrm{D}_{30}, \mathrm{D}_{60}, \mathrm{C}_{u}$ and $C_{c}$ of the gravel were investigated. As shown in Figure 42 and Figure 43, little relationship exists between these gravel gradational properties and penetration depth or bound material for three different water ratios. A similar lack of relationship between $\mathrm{D}_{30}, \mathrm{D}_{60}, \mathrm{C}_{\mathrm{u}}$ and $\mathrm{C}_{\mathrm{c}}$ of the gravel exist and were investigated. Therefore, extending this information to gravels of other gradations does not seem plausible with these basic gradational descriptors. 


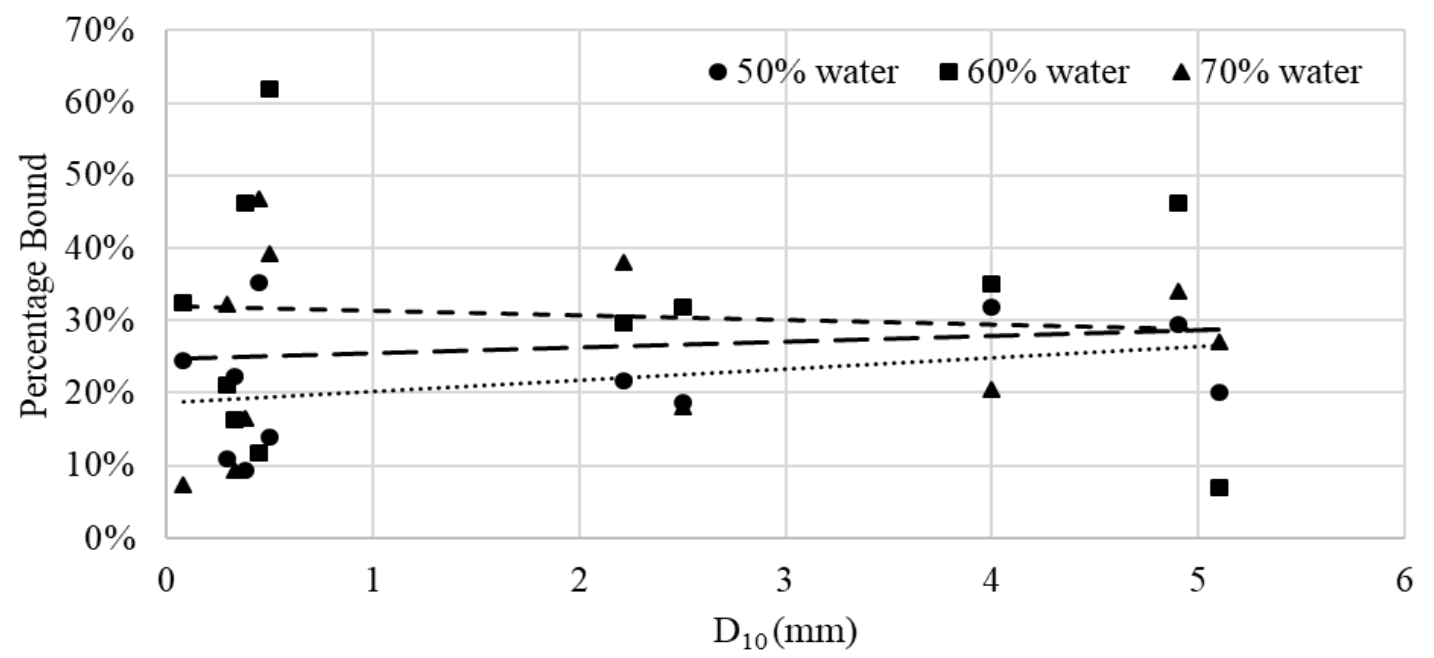

Figure 42 - Results of pour tests for percentage bound material correlated to D10 of the gravel (ash/cement ratio 1.5)

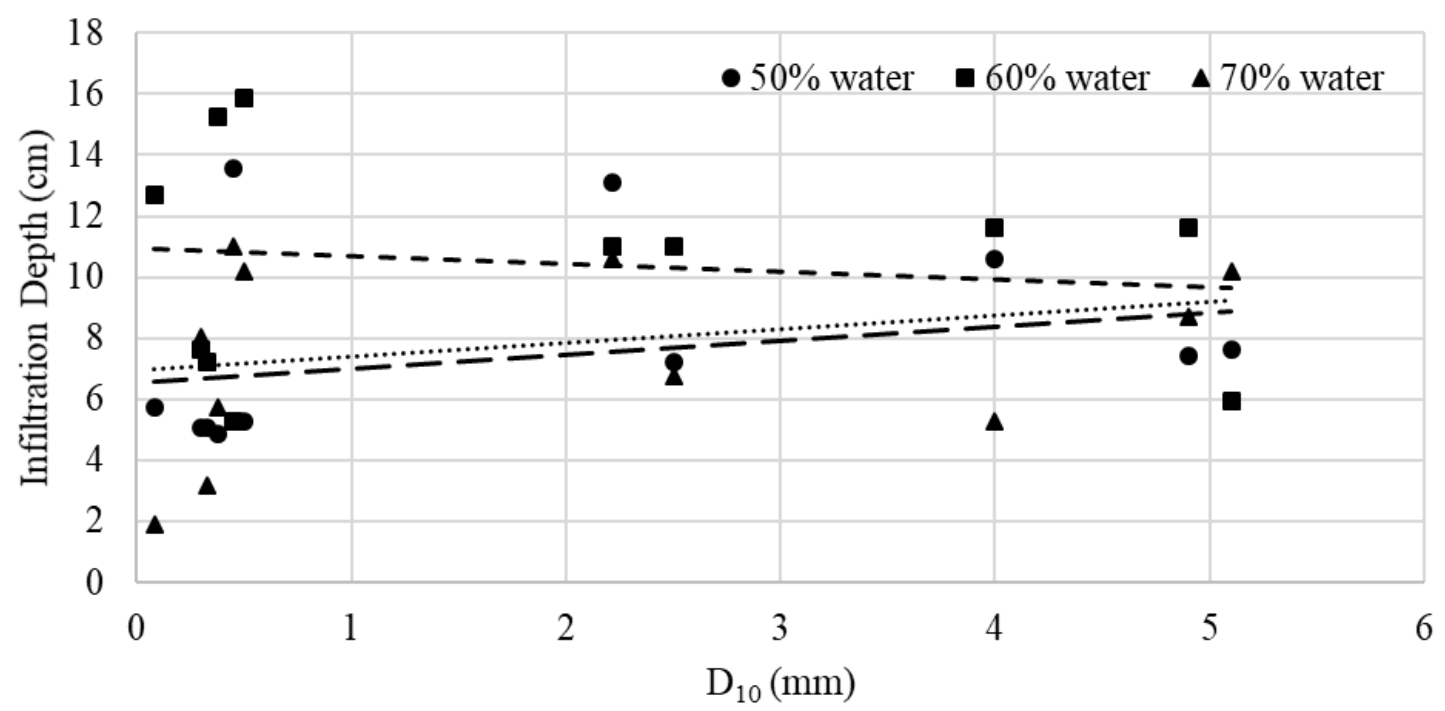

Figure 43 - Results of pour tests for infiltration depth correlated to $D_{10}$ of the gravel (ash/cement ratio 1.5)

\subsubsection{All Correlations of Data Collected}

Table 23 includes the variables introduced, used, and discovered throughout the course of this project when compared through linear regression to each other. Limits were placed on the degree that a correlation would be sought, keeping the line of best fit equation to under a third order polynomial, for example. Cells with "Limited" as the entry mean there is not enough data shared by the two variables to reach a valid conclusion, generally only one or two data points. "No Comparison" means that one variable has no effect on the other; these only exist between the gravel characteristics and the mortar cube testing results. In the center of the table is a large section of "Controlled" entries. These mean that the variable was an independent variable that was controlled during testing, therefore there is no correlation among each other. The purpose of this table was to record and clearly show what variables had correlations with each other. 
Table 23. Data collected and linear regression interpretation for this project

\begin{tabular}{|c|c|c|c|c|c|c|c|c|c|c|c|c|c|c|c|c|c|c|c|}
\hline $\begin{array}{c}\text { Correlation } \\
\text { Between } \\
\text { Variables }\end{array}$ & $\begin{array}{c}\text { Cement } \\
\text { Compressive } \\
\text { Strength }\end{array}$ & $\begin{array}{c}\text { Infiltration } \\
\text { Depth }\end{array}$ & $\begin{array}{l}\text { Percentage } \\
\text { Bound }\end{array}$ & D10 & D30 & D60 & $\begin{array}{l}\text { Coefficient } \\
\quad \text { of } \\
\text { Uniformity }\end{array}$ & $\begin{array}{l}\text { Coefficient } \\
\text { of } \\
\text { Curvature }\end{array}$ & $\begin{array}{c}\text { Mixture } \\
\text { Water } \\
\text { Percentage }\end{array}$ & $\begin{array}{l}\text { Volcanic } \\
\text { Ash Ratio }\end{array}$ & Firmness & Stability & $\begin{array}{c}\text { Combined } \\
\text { Firmness } \\
\text { and } \\
\text { Stability }\end{array}$ & $\begin{array}{c}\text { Change } \\
\text { in } \\
\text { Firmness }\end{array}$ & $\begin{array}{l}\text { Change } \\
\text { in } \\
\text { Stability }\end{array}$ & $\begin{array}{c}\text { Combined } \\
\text { Change }\end{array}$ & $\begin{array}{l}\text { \% Sample } \\
\text { Strength }\end{array}$ & $\begin{array}{c}\% \text { Control } \\
\text { Strength }\end{array}$ & Cure Time \\
\hline $\begin{array}{c}\text { Cement } \\
\text { Compressive } \\
\text { Strength }\end{array}$ & 1 & $\begin{array}{l}0.5, \text { 2nd } \\
\text { Order }\end{array}$ & $\begin{array}{l}<0.99, \text { 2nd } \\
\text { Order }\end{array}$ & Limited & Limited & Limited & Limited & Limited & Limited & $\begin{array}{c}<0.98, \text { 2nd } \\
\text { Order }\end{array}$ & Limited & Limited & Limited & Limited & Limited & Limited & 1, linear & $\begin{array}{l}>0.96, \\
\text { Linear }\end{array}$ & $\begin{array}{l}>0.97, \text { 2nd } \\
\text { Order }\end{array}$ \\
\hline $\begin{array}{c}\text { Infiltration } \\
\text { Depth }\end{array}$ & $\begin{array}{l}0.5, \text {,nd } \\
\text { Order }\end{array}$ & 1 & $\begin{array}{l}0.46, \\
\text { Linear }\end{array}$ & $\begin{array}{l}>0.10, \\
\text { Linear }\end{array}$ & $\begin{array}{l}>0.30, \\
\text { Linear }\end{array}$ & $\begin{array}{l}>0.15, \\
\text { Linear }\end{array}$ & $\begin{array}{l}>0.41, \\
\text { Linear }\end{array}$ & $\begin{array}{l}>0.30, \\
\text { Linear }\end{array}$ & $\begin{array}{l}<0.2,2 \text {, nd } \\
\text { Order }\end{array}$ & $\begin{array}{l}<0.1,2 \text {, nd } \\
\text { Order }\end{array}$ & $\begin{array}{c}0.41,2 \text { nd } \\
\text { Order }\end{array}$ & $\begin{array}{l}0.10, \\
\text { 2nd } \\
\text { Order }\end{array}$ & $\begin{array}{c}0.14, \text { nnd } \\
\text { Order }\end{array}$ & $>0.1, \log$ & $\begin{array}{l}>0.1, \\
\text { Log }\end{array}$ & $>0.3, \log$ & $\begin{array}{c}>0.88, \text { 2nd } \\
\text { Order }\end{array}$ & $\begin{array}{l}0.5,2 \text {, d } \\
\text { Order }\end{array}$ & Limited \\
\hline $\begin{array}{c}\text { Percentage } \\
\text { Bound }\end{array}$ & $\begin{array}{l}<0.99 \text {, 2nd } \\
\text { Order }\end{array}$ & $\begin{array}{l}\text { 0.46, } \\
\text { Linear }\end{array}$ & 1 & $\begin{array}{l}<0.13, \\
\text { Linear }\end{array}$ & $\begin{array}{l}<0.13, \\
\text { Linear }\end{array}$ & $\begin{array}{l}<0.4, \\
\text { Linear }\end{array}$ & $\begin{array}{l}<0.23, \\
\text { Linear }\end{array}$ & $\begin{array}{l}<0.35, \\
\text { Linear }\end{array}$ & $\begin{array}{l}<0.14, \text { 2nd } \\
\text { Order }\end{array}$ & $\begin{array}{l}<0.1,2 \text { nd } \\
\text { Order }\end{array}$ & $\begin{array}{c}0.41,2 \text { nd } \\
\text { Order }\end{array}$ & $\begin{array}{l}0.10, \\
\text { 2nd } \\
\text { Order }\end{array}$ & $\begin{array}{c}0.14, \text { 2nd } \\
\text { Order }\end{array}$ & $>0.1, \log$ & $\begin{array}{l}>0.1 \\
\text { Log }\end{array}$ & $>0.1, \log$ & $\begin{array}{l}0.94,2 \text { nd } \\
\text { Order }\end{array}$ & $\begin{array}{c}0.99,2 \text {, nd } \\
\text { Order }\end{array}$ & Limited \\
\hline D10 & Limited & $\begin{array}{l}>0.10, \\
\text { Linear }\end{array}$ & $\begin{array}{l}<0.13, \\
\text { Linear }\end{array}$ & 1 & Controlled & Controlled & Controlled & Controlled & Controlled & Controlled & $\begin{array}{c}.53, \\
\text { Expon. }\end{array}$ & $\begin{array}{c}74, \\
\text { Expon. }\end{array}$ & $\begin{array}{c}\text {.73, } \\
\text { Expon. }\end{array}$ & Limited & Limited & Limited & $\begin{array}{c}\text { No } \\
\text { Comparison }\end{array}$ & \begin{tabular}{c|}
$\mathrm{No}$ \\
Comparison \\
\end{tabular} & \begin{tabular}{|c|} 
No \\
Comparison
\end{tabular} \\
\hline D30 & Limited & $\begin{array}{l}\text { >0.30, } \\
\text { Linear }\end{array}$ & $\begin{array}{l}<0.13, \\
\text { Linear }\end{array}$ & Controlled & 1 & Controlled & Controlled & Controlled & Controlled & Controlled & $\begin{array}{l}.51, \\
\text { Expon. }\end{array}$ & $\begin{array}{l}.76, \text { 2nd } \\
\text { Order }\end{array}$ & $\begin{array}{l}.74, \text {, nd } \\
\text { Order }\end{array}$ & Limited & Limited & Limited & \begin{tabular}{c|} 
No \\
Comparison
\end{tabular} & \begin{tabular}{c|} 
No \\
Comparison
\end{tabular} & \begin{tabular}{|c|c|} 
No \\
Comparison
\end{tabular} \\
\hline D60 & Limited & $\begin{array}{l}>0.15, \\
\text { Linear }\end{array}$ & $\begin{array}{l}\text { <..4, } \\
\text { Linear }\end{array}$ & Controlled & Controlled & 1 & Controlled & Controlled & Controlled & Controlled & $\begin{array}{l}.44, \text { 2nd } \\
\text { Order }\end{array}$ & $\begin{array}{c}.76,2 \text { nd } \\
\text { Order }\end{array}$ & $\begin{array}{l}.74, \text { 2nd } \\
\text { Order }\end{array}$ & Limited & Limited & Limited & \begin{tabular}{c|} 
No \\
Comparison
\end{tabular} & \begin{tabular}{c|} 
No \\
Comparison
\end{tabular} & $\begin{array}{c}\text { No } \\
\text { Comparison }\end{array}$ \\
\hline \begin{tabular}{l|} 
Coefficient \\
of \\
Uniformitv
\end{tabular} & Limited & $\begin{array}{l}>0.41, \\
\text { Linear }\end{array}$ & $\begin{array}{l}<0.23, \\
\text { Linear }\end{array}$ & Controlled & Controlled & Controlled & 1 & Controlled & Controlled & Controlled & $\begin{array}{l}.52, \\
\text { Expon. }\end{array}$ & $\begin{array}{l}.76,2 \text { nd } \\
\text { Order }\end{array}$ & $\begin{array}{l}.75, \\
\text { Expon. }\end{array}$ & Limited & Limited & Limited & \begin{tabular}{c|c} 
No \\
Comparison
\end{tabular} & \begin{tabular}{c|c} 
No \\
Comparison
\end{tabular} & $\begin{array}{c}\text { No } \\
\text { Comparison }\end{array}$ \\
\hline $\begin{array}{l}\text { Coefficient } \\
\text { of } \\
\text { Curvature } \\
\end{array}$ & Limited & $\begin{array}{l}\text { >0.30, } \\
\text { Linear }\end{array}$ & 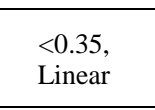 & Controlled & Controlled & Controlled & Controlled & 1 & Controlled & Controlled & $\begin{array}{c}.53, \\
\text { Expon. }\end{array}$ & $\begin{array}{l}.76, \text { 2nd } \\
\text { Order } \\
\end{array}$ & $\begin{array}{c}.74, \\
\text { Expon. }\end{array}$ & Limited & Limited & Limited & $\begin{array}{c}\text { No } \\
\text { Comparison }\end{array}$ & \begin{tabular}{c|} 
No \\
Comparison
\end{tabular} & $\begin{array}{c}\text { No } \\
\text { Comparison } \\
\end{array}$ \\
\hline \begin{tabular}{|c|} 
Mixture \\
Water \\
Percentage
\end{tabular} & Limited & $\begin{array}{l}<0.2,2 \text {, nd } \\
\text { Order }\end{array}$ & $\begin{array}{l}<0.14, \text { 2nd } \\
\text { Order }\end{array}$ & Controlled & Controlled & Controlled & Controlled & Controlled & 1 & Controlled & Limited & Limited & Limited & Limited & Limited & Limited & \begin{tabular}{c|c} 
No \\
Comparison
\end{tabular} & \begin{tabular}{c|c} 
No \\
Comparison
\end{tabular} & $\begin{array}{c}\text { No } \\
\text { Comparison }\end{array}$ \\
\hline $\begin{array}{l}\text { Volcanic } \\
\text { Ash Ratio }\end{array}$ & $\begin{array}{l}<0.98, \text { 2nd } \\
\text { Order }\end{array}$ & $\begin{array}{l}<0.1,2 \text { nd } \\
\text { Order }\end{array}$ & $\begin{array}{l}<0.1,2 \text { nd } \\
\text { Order }\end{array}$ & Controlled & Controlled & Controlled & Controlled & Controlled & Controlled & 1 & Limited & Limited & Limited & Limited & Limited & Limited & \begin{tabular}{c|c} 
No \\
Comparison
\end{tabular} & \begin{tabular}{c|}
$\mathrm{No}$ \\
Comparison \\
\end{tabular} & \begin{tabular}{|c|} 
No \\
Comparison
\end{tabular} \\
\hline Firmness & Limited & $\begin{array}{l}0.41,2 \mathrm{nd} \\
\text { Order }\end{array}$ & $\begin{array}{l}0.41,2 \mathrm{nd} \\
\text { Order }\end{array}$ & .53 , Expon. & .51 , Expon. & $\begin{array}{l}.44,2 \text { nd } \\
\text { Order }\end{array}$ & .52 , Expon. & .53 , Expon. & Limited & Limited & 1 & $\begin{array}{c}0.88, \text { 3rd } \\
\text { Order }\end{array}$ & $\begin{array}{l}0.90,3 r d \\
\text { Order }\end{array}$ & $\begin{array}{c}0.63,2 \mathrm{nd} \\
\text { Order }\end{array}$ & $\begin{array}{l}0.57, \\
\text { 2nd } \\
\text { Order }\end{array}$ & $\begin{array}{l}0.65,2 \mathrm{nd} \\
\text { Order }\end{array}$ & Limited & Limited & Limited \\
\hline Stability & Limited & $\begin{array}{c}0.10,2 \text { nd } \\
\text { Order }\end{array}$ & $\begin{array}{c}0.10,2 \mathrm{nd} \\
\text { Order }\end{array}$ & .74, Expon. & $\begin{array}{l}.76, \text { 2nd } \\
\text { Order } \\
\end{array}$ & $\begin{array}{l}.76,2 \text { nd } \\
\text { Order } \\
\end{array}$ & $\begin{array}{l}.76,2 \text {, nd } \\
\text { Order } \\
\end{array}$ & $\begin{array}{l}.76, \text { 2nd } \\
\text { Order } \\
\end{array}$ & Limited & Limited & $\begin{array}{c}0.88,3 \mathrm{rdd} \\
\text { Order }\end{array}$ & 1 & $\begin{array}{l}\text { >0.99, } \\
\text { Linear } \\
\end{array}$ & $\begin{array}{c}<0.3,2 \text { nd } \\
\text { Order }\end{array}$ & $\begin{array}{l}\begin{array}{l}0.98, \\
\text { 2nd } \\
\text { order }\end{array} \\
\end{array}$ & $\begin{array}{c}>0.98,2 \text {, nd } \\
\text { order }\end{array}$ & Limited & Limited & Limited \\
\hline \begin{tabular}{|c|} 
Combined \\
Firmness \\
and Stability
\end{tabular} & Limited & $\begin{array}{c}0.14, \text { 2nd } \\
\text { Order }\end{array}$ & $\begin{array}{c}0.14, \text { 2nd } \\
\text { Order }\end{array}$ & .73 , Expon. & $\begin{array}{l}.74, \text { 2nd } \\
\text { Order }\end{array}$ & $\begin{array}{l}.74, \text { 2nd } \\
\text { Order }\end{array}$ & .75 , Expon. & .74, Expon. & Limited & Limited & $\begin{array}{c}0.90,3 r d \\
\text { Order }\end{array}$ & $\begin{array}{l}>0.99, \\
\text { Linear }\end{array}$ & 1 & $\begin{array}{c}<0.3, \text { 2nd } \\
\text { Order }\end{array}$ & $\begin{array}{l}>0.97, \\
\text { 2nd } \\
\text { Order }\end{array}$ & $\begin{array}{c}>0.98,2 \text {, nd } \\
\text { order }\end{array}$ & Limited & Limited & Limited \\
\hline $\begin{array}{l}\text { Change in } \\
\text { Firmness }\end{array}$ & Limited & $>0.1, \log$ & $>0.1, \log$ & Limited & Limited & Limited & Limited & Limited & Limited & Limited & $\begin{array}{c}0.63,2 \mathrm{nd} \\
\text { Order } \\
\end{array}$ & $\begin{array}{l}<0.3, \\
\text { 2nd } \\
\text { Order }\end{array}$ & $\begin{array}{c}<0.3,2 \text { nd } \\
\text { Order }\end{array}$ & 1 & $\begin{array}{l}0.20, \\
\text { 2nd } \\
\text { order }\end{array}$ & $\begin{array}{c}<0.3,2 \text {, nd } \\
\text { Order }\end{array}$ & Limited & Limited & Limited \\
\hline $\begin{array}{l}\text { Change in } \\
\text { Stability }\end{array}$ & Limited & $>0.1, \log$ & $>0.1, \log$ & Limited & Limited & Limited & Limited & Limited & Limited & Limited & $\begin{array}{l}0.57,2 \mathrm{nd} \\
\text { Order }\end{array}$ & $\begin{array}{l}>0.98, \\
\text { 2nd } \\
\text { order }\end{array}$ & $\begin{array}{c}>0.97, \text { 2nd } \\
\text { Order }\end{array}$ & $\begin{array}{c}0.20,2 \text { nd } \\
\text { order }\end{array}$ & 1 & $\begin{array}{l}>0.98, \\
\text { linear }\end{array}$ & Limited & Limited & Limited \\
\hline $\begin{array}{c}\text { Combined } \\
\text { Change }\end{array}$ & Limited & $>0.3, \log$ & $>0.1, \log$ & Limited & Limited & Limited & Limited & Limited & Limited & Limited & $\begin{array}{c}0.65,2 \mathrm{nd} \\
\text { Order } \\
\end{array}$ & $\begin{array}{l}>0.98, \\
\text { 2nd } \\
\text { order }\end{array}$ & $\begin{array}{c}>0.98,2 \text {, nd } \\
\text { order }\end{array}$ & $\begin{array}{c}<0.3,2 \mathrm{nd} \\
\text { Order } \\
\end{array}$ & $\begin{array}{l}>0.98, \\
\text { linear }\end{array}$ & 1 & Limited & Limited & Limited \\
\hline $\begin{array}{c}\text { \% Sample } \\
\text { Strength }\end{array}$ & 1, Linear & $\begin{array}{c}>0.88, \text { 2nd } \\
\text { Order }\end{array}$ & $\begin{array}{c}0.94, \text { 2nd } \\
\text { Order }\end{array}$ & $\begin{array}{c}\text { No } \\
\text { Comparison }\end{array}$ & $\begin{array}{c}\text { No } \\
\text { Comparison } \\
\end{array}$ & $\begin{array}{c}\text { No } \\
\text { Comparison }\end{array}$ & $\begin{array}{c}\text { No } \\
\text { Comparison }\end{array}$ & $\begin{array}{c}\text { No } \\
\text { Comparison }\end{array}$ & $\begin{array}{c}\text { No } \\
\text { Comparison }\end{array}$ & $\begin{array}{c}\text { No } \\
\text { Comparison }\end{array}$ & Limited & Limited & Limited & Limited & Limited & Limited & 1 & $\begin{array}{l}>0.96, \\
\text { Linear }\end{array}$ & $\begin{array}{l}>0.97,2 \text { nd } \\
\text { Order }\end{array}$ \\
\hline $\begin{array}{c}\text { Control } \\
\text { Strength }\end{array}$ & $>0.96$, Linear & $\begin{array}{c}0.5, \text {, nd } \\
\text { Order } \\
\text { Ord }\end{array}$ & $\begin{array}{c}0.99,2 \text {, nd } \\
\text { Order }\end{array}$ & $\begin{array}{c}\text { No } \\
\text { Comparison }\end{array}$ & $\begin{array}{c}\text { No } \\
\text { Comparison } \\
\end{array}$ & $\begin{array}{c}\text { No } \\
\text { Comparison }\end{array}$ & $\begin{array}{c}\text { No } \\
\text { Comparison }\end{array}$ & $\begin{array}{c}\text { No } \\
\text { Comparison }\end{array}$ & $\begin{array}{c}\text { No } \\
\text { Comparison }\end{array}$ & $\begin{array}{c}\text { No } \\
\text { Comparison }\end{array}$ & Limited & Limited & Limited & Limited & Limited & Limited & $\begin{array}{l}>0.96, \\
\text { Linear }\end{array}$ & 1 & $\begin{array}{l}<0.66, \\
\text { Linear }\end{array}$ \\
\hline Cure Time & $\begin{array}{l}0.97,2 \text { nd } \\
\text { Order }\end{array}$ & Limited & Limited & $\begin{array}{c}\text { No } \\
\text { Comparison }\end{array}$ & $\begin{array}{c}\text { No } \\
\text { Comparison } \\
\text { Con }\end{array}$ & $\begin{array}{c}\text { No } \\
\text { Comparison } \\
\end{array}$ & $\begin{array}{c}\text { No } \\
\text { Comparison }\end{array}$ & $\begin{array}{c}\text { No } \\
\text { Comparison } \\
\end{array}$ & $\begin{array}{c}\text { No } \\
\text { Comparison } \\
\end{array}$ & $\begin{array}{c}\text { No } \\
\text { Comparison } \\
\end{array}$ & Limited & Limited & Limited & Limited & Limited & Limited & $\begin{array}{c}>0.97,2 \text {, nd } \\
\text { Order }\end{array}$ & $\begin{array}{l}<0.66, \\
\text { Linear }\end{array}$ & 1 \\
\hline
\end{tabular}




\subsection{CONCLUSIONS}

An extensive laboratory and field study has been conducted to determine the effectiveness of using volcanic ash to increase the firmness and stability of unpaved trail surfaces. Volcanic ash was obtained from Klamath County, OR, and processed with a commercial rock crusher. This increased the fineness of the material to a level suitable for use as a natural pozzolan.

Mortar cubes were created with volcanic ash, portland cement, processed oyster shells and lime. It was shown that volcanic ash can create weakly cemented products without portland cement. Mortar cubes created with volcanic ash showed appreciable gains in strength between 28 and 84 days of curing. The control, SC-0, displayed no increase in strength between 42 and 84 days of curing. However, samples with volcanic ash showed significant gains in strength between 42 and 84 days. There is considerable decrease in compressive strength when portland cement is replaced with volcanic ash. This decrease is predictable based on the correlations shown in Figure 30.

A large number of mix infiltration tests were completed to determine the best possible mixtures that could bind the largest amount of particles. Both the depth of penetration and percentage of bound material was measured for different mixtures. For these two measurements, a correlation was attempted to be found between common gravel gradation descriptors. Despite creating and testing 185 separate samples, no clear correlation between gravel gradational characteristics and bound material is found for portland cement and volcanic ash mixtures of different amounts of water and varying ash to cement ratios. There is a positive correlation between the bound material and depth of infiltration. Depth of infiltration increases as the amount of water in the mixture increases.

A lab-scale testing device was constructed with adjustable confinement to refine the process of applying the topical mix. These lab-scale tests showed that compaction of the gravel sample increased firmness and stability a minor amount. In addition, confinement does not appear to have a significant impact on firmness and stability. Using the lab-scale testing device, it was determined that the topical application could not be sprayed and must be poured onto the surface.

Field-scale testing has been conducted with 12 lots of applied treatment. All treated lots experienced an average increase in firmness over 70 days. The change in firmness of the commercially treated lots were much less than the portland cement and volcanic ash treated lots. In terms of stability, positive and negative changes with time were experienced for the portland cement and volcanic ash treated lots. However, negative, or decreases, in stability with time were shown in the commercially treated lots. This indicates that the long-term gains in strength shown with the portland cement and volcanic ash mixes in the mortar cubes could be contributing to increases in firmness and stability with time. The commercially treated surfaces appear to be degrading in stability with time in contrast to the portland cement and volcanic ash treated surfaces. 


\subsection{REFERENCES}

“2010 ADA Standards for Accessible Design.” September 15, 2010. Accessed November 24, 2019. https://www.ada.gov/regs2010/2010ADAStandards/2010ADAstandards.htm.

Arel, H.S., (2016), "Effects of curing type, silica fume fineness, and fiber length on the mechanical properties and impact resistance of UHPFRC," Results in Physics, Vol. 6. p. 664-674.

Architectural Barriers Act (ABA) Standards. (2015). Washington, DC: GPO.

ASTM C109 / C109M-16a, Standard Test Method for Compressive Strength of Hydraulic Cement Mortars (Using 2-in. or [50-mm] Cube Specimens), ASTM International, West Conshohocken, PA, 2016, doi: 10.1520/C0109_C0109M-16A

ASTM C114-15, Standard Test Methods for Chemical Analysis of Hydraulic Cement, ASTM International, West Conshohocken, PA, 2015, doi: 10.1520/C0114-15

ASTM C144-17, Standard Specification for Aggregate for Masonry Mortar, ASTM International, West Conshohocken, PA, 2017, doi: 10.1520/C0144-17

ASTM C311 / C311M-17, Standard Test Methods for Sampling and Testing Fly Ash or Natural Pozzolans for Use in Portland-Cement Concrete, ASTM International, West Conshohocken, PA, 2017, doi:10.1520/C0311_C0311M-17

ASTM C430-17, Standard Test Method for Fineness of Hydraulic Cement by the 45- $\mu \mathrm{m}$ (No. 325) Sieve, ASTM International, West Conshohocken, PA, 2017, www.astm.org

ASTM C618-17a, Standard Specification for Coal Fly Ash and Raw or Calcined Natural Pozzolan for Use in Concrete, ASTM International, West Conshohocken, PA, 2017, doi: 10.1520/C0618-17A

Axelson, P., and Hurley, S. 2017. "Use of two test methods to ensure accurate surface firmness and stability measurements for accessibility,” Disability and Rehabilitation: Assistive Technology, DOI: 10.1080/17483107.2017.1328618.

Baerbel L., (2013), "Volcanic Ash versus Mineral Dust: Atmospheric Processing and Environmental and Climate Impacts,” ISRN Atmospheric Sciences, vol. 2013, Article ID 245076, 17 pages. https://doi.org/10.1155/2013/245076.

Beneficial Designs, Inc., (2014), Rotational Penetrometer 100 Series Instruction Manual.

California State Parks Accessibility Section Acquisition and Development Division. 2009. “California State Parks Accessibility Guidelines 2009 Edition,” 286.

Dodson V.H. (1990) Pozzolans and the Pozzolanic Reaction. In: Concrete Admixtures. Springer, Boston, MA 
Duncan, J.M. (2008), “Methods for Evaluating the Permeability of Soils,” Center for Geotechnical Practice and Research No. 51, Virginia Tech, Blacksburg, VA.

Hossain, K. and Lachemi, M., (2006), “Development of Volcanic Ash Concrete: Strength, Durability, and Microstructural Investigations, ACE Materials Journal, Vol. 103, No. 1, p. 11

Liang, C., and Wang., H., (2013), "Feasibility of Pulverized Oyster Shell as a Cementing Materials,” Advances in Materials Science and Engineering, Vo. 2013, p. 7.

Mehta, P.K. (1987). "Natural pozzolans: Supplementary cementing materials in concrete". CANMET Special Publication. 86: 1-33

Moore Inacofano Goltsman, Inc. June 2006. "Malibu Parks Public Access Enhancement Plan Park and Trail Accessibility Design Guidelines,” 58.

Papadakis, V., and Tsimas, S., (2002), "Supplementary cementing materials in concrete: part I efficiency and design,” Cement and Concrete Research, Vol. 32, No. 10 p. 1552-1532.

Richards, Bob. April 2007. “ADA Accessibility Guidelines,” 13.

Seo, J.H., Park, S.M., Yang, B.J., \& Jang, J.G., (2019), “Calcined Oyster Shell Powder as an Expansive Additive in Cement Mortar,” Materials.

Taylor, H.E. and Lichte, F.E., (1980), "Chemical composition of Mount St. Helens Volcanic Ash,” Geophysical Research Letters, AGU, Vol. 7, No. 11, p. 949-952.

Toutanji, H., Delatte, N., Aggoun, S., Doval, R., Danson, A., (2004), “Effecto fo supplementary cementitious materails on the compressive strength and durability of short-term cured concrete,” Cem.Concre.Res., 34(2), p. 311-319.

US Forest Service. 2013. “Forest Service Trail Accessibility Guidelines,” 37.

Zeller, Janet, Ruth Doyle, and Kathleen Snodgrass. August 2012. “Accessibility Guidebook for Outdoor Recreation and Trails,” 133. 


\subsection{APPENDIX}

\subsection{MORTAR CUBE INFORMATION}

Table 24. Unconfined compressive strength of mortar cubes

\begin{tabular}{|l|r|r|r|r|r|r|r|r|}
\hline & \multicolumn{7}{|c|}{ Cure Time (days) } \\
\hline & 0 & 7 & 21 & 28 & 42 & 56 & 70 & 84 \\
\hline Sample & \multicolumn{7}{|c|}{ Unconfined Compressive Strength (psi) } \\
\hline SC-0 & 0 & 5744 & 6335 & 6631 & 6980 & 6980 & 6980 & 6980 \\
\hline SC-1 & 0 & 3856 & 4274 & 4483 & 4933 & 5168 & 5241 & 5289 \\
\hline SC-2 & 0 & 2629 & 2844 & 2952 & 3155 & 3183 & 3496 & 3808 \\
\hline SC-3 & 0 & 1583 & 1839 & 1967 & 2148 & 2218 & 2481 & 2543 \\
\hline SC-4 & 0 & 65 & 103 & 123 & 130 & 138 & 148 & 158 \\
\hline LC-0 & 0 & 25 & 48 & 60 & 40 & 53 & 50 & 48 \\
\hline LC-1 & 0 & 55 & 108 & 135 & 175 & 228 & 195 & 243 \\
\hline LC-2 & 0 & 48 & 113 & 145 & 223 & 225 & 300 & 318 \\
\hline LC-3 & 0 & 45 & 97 & 123 & 145 & 173 & 208 & 200 \\
\hline OC-0 & 0 & 38 & 59 & 70 & 45 & 80 & 73 & 130 \\
\hline OC-1 & 0 & 43 & 131 & 175 & 178 & 235 & 240 & 306 \\
\hline OC-2 & 0 & 48 & 124 & 163 & 170 & 228 & 295 & 311 \\
\hline OC-3 & 0 & 35 & 103 & 138 & 210 & 178 & 262 & 330 \\
\hline LPC-0 & 0 & 68 & 39 & 25 & 40 & 46 & 45 & 43 \\
\hline LPC-1 & 0 & 45 & 92 & 115 & 150 & 180 & 195 & 264 \\
\hline LPC-2 & 0 & 43 & 103 & 133 & 294 & 225 & 266 & 315 \\
\hline LPC-3 & 0 & 40 & 87 & 110 & 160 & 193 & 215 & 225 \\
\hline OPC-0 & 0 & 23 & 66 & 87 & 52 & 38 & 40 & 51 \\
\hline OPC-1 & 0 & 38 & 78 & 98 & 105 & 165 & 190 & 208 \\
\hline OPC-2 & 0 & 40 & 90 & 115 & 150 & 203 & 238 & 257 \\
\hline OPC-3 & 0 & 33 & 81 & 105 & 160 & 230 & 248 & 328 \\
\hline RC-0 & 0 & 34 & 37 & 43 & 54 & 47 & 40 & 47 \\
\hline RC-1 & 0 & 50 & 58 & 58 & 90 & 110 & 130 & 175 \\
\hline RC-2 & 0 & 65 & 103 & 121 & 125 & 158 & 190 & 205 \\
\hline RC-3 & 0 & 55 & 114 & 144 & 178 & 228 & 279 & 350 \\
\hline
\end{tabular}


Table 25. Percentage of unconfined compressive strength (control = SC-0)

\begin{tabular}{|l|r|r|r|r|r|r|r|r|}
\hline & \multicolumn{7}{|c|}{ Cure Time (days) } \\
\hline & 0 & 7 & 21 & 28 & 42 & 56 & 70 & 84 \\
\hline & \multicolumn{7}{|c|}{ Percentage of Control Strength (SC-0) } \\
\hline SC-0 & $0 \%$ & $100 \%$ & $100 \%$ & $100 \%$ & $100 \%$ & $100 \%$ & $100 \%$ & $100 \%$ \\
\hline SC-1 & $0 \%$ & $67 \%$ & $67 \%$ & $68 \%$ & $71 \%$ & $74 \%$ & $75 \%$ & $76 \%$ \\
\hline SC-2 & $0 \%$ & $46 \%$ & $45 \%$ & $45 \%$ & $45 \%$ & $46 \%$ & $50 \%$ & $55 \%$ \\
\hline SC-3 & $0 \%$ & $28 \%$ & $29 \%$ & $30 \%$ & $31 \%$ & $32 \%$ & $36 \%$ & $36 \%$ \\
\hline SC-4 & $0 \%$ & $1 \%$ & $2 \%$ & $2 \%$ & $2 \%$ & $2 \%$ & $2 \%$ & $2 \%$ \\
\hline LC-0 & $0 \%$ & $0 \%$ & $1 \%$ & $1 \%$ & $1 \%$ & $1 \%$ & $1 \%$ & $1 \%$ \\
\hline LC-1 & $0 \%$ & $1 \%$ & $2 \%$ & $2 \%$ & $3 \%$ & $3 \%$ & $3 \%$ & $3 \%$ \\
\hline LC-2 & $0 \%$ & $1 \%$ & $2 \%$ & $2 \%$ & $3 \%$ & $3 \%$ & $4 \%$ & $5 \%$ \\
\hline LC-3 & $0 \%$ & $1 \%$ & $2 \%$ & $2 \%$ & $2 \%$ & $2 \%$ & $3 \%$ & $3 \%$ \\
\hline OC-0 & $0 \%$ & $1 \%$ & $1 \%$ & $1 \%$ & $1 \%$ & $1 \%$ & $1 \%$ & $2 \%$ \\
\hline OC-1 & $0 \%$ & $1 \%$ & $2 \%$ & $3 \%$ & $3 \%$ & $3 \%$ & $3 \%$ & $4 \%$ \\
\hline OC-2 & $0 \%$ & $1 \%$ & $2 \%$ & $2 \%$ & $2 \%$ & $3 \%$ & $4 \%$ & $4 \%$ \\
\hline OC-3 & $0 \%$ & $1 \%$ & $2 \%$ & $2 \%$ & $3 \%$ & $3 \%$ & $4 \%$ & $5 \%$ \\
\hline LPC-0 & $0 \%$ & $1 \%$ & $1 \%$ & $0 \%$ & $1 \%$ & $1 \%$ & $1 \%$ & $1 \%$ \\
\hline LPC-1 & $0 \%$ & $1 \%$ & $1 \%$ & $2 \%$ & $2 \%$ & $3 \%$ & $3 \%$ & $4 \%$ \\
\hline LPC-2 & $0 \%$ & $1 \%$ & $2 \%$ & $2 \%$ & $4 \%$ & $3 \%$ & $4 \%$ & $5 \%$ \\
\hline LPC-3 & $0 \%$ & $1 \%$ & $1 \%$ & $2 \%$ & $2 \%$ & $3 \%$ & $3 \%$ & $3 \%$ \\
\hline OPC-0 & $0 \%$ & $0 \%$ & $1 \%$ & $1 \%$ & $1 \%$ & $1 \%$ & $1 \%$ & $1 \%$ \\
\hline OPC-1 & $0 \%$ & $1 \%$ & $1 \%$ & $1 \%$ & $2 \%$ & $2 \%$ & $3 \%$ & $3 \%$ \\
\hline OPC-2 & $0 \%$ & $1 \%$ & $1 \%$ & $2 \%$ & $2 \%$ & $3 \%$ & $3 \%$ & $4 \%$ \\
\hline OPC-3 & $0 \%$ & $1 \%$ & $1 \%$ & $2 \%$ & $2 \%$ & $3 \%$ & $4 \%$ & $5 \%$ \\
\hline RC-0 & $0 \%$ & $1 \%$ & $1 \%$ & $1 \%$ & $1 \%$ & $1 \%$ & $1 \%$ & $1 \%$ \\
\hline RC-1 & $0 \%$ & $1 \%$ & $1 \%$ & $1 \%$ & $1 \%$ & $2 \%$ & $2 \%$ & $3 \%$ \\
\hline RC-2 & $0 \%$ & $1 \%$ & $2 \%$ & $2 \%$ & $2 \%$ & $2 \%$ & $3 \%$ & $3 \%$ \\
\hline RC-3 & $0 \%$ & $1 \%$ & $2 \%$ & $2 \%$ & $3 \%$ & $3 \%$ & $4 \%$ & $5 \%$ \\
\hline
\end{tabular}




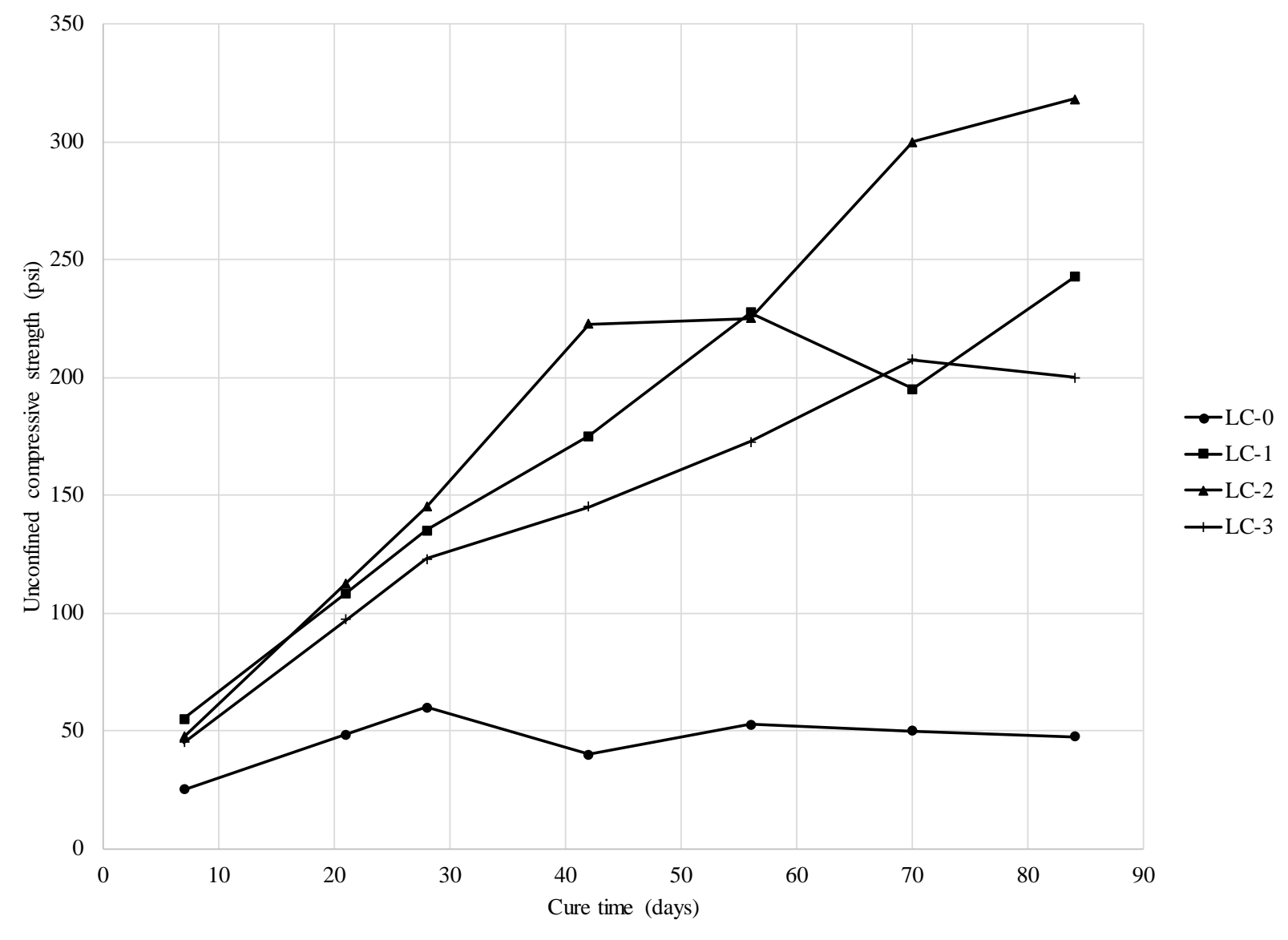

Figure 44 - Unconfined compressive strength with time (LC Samples) 


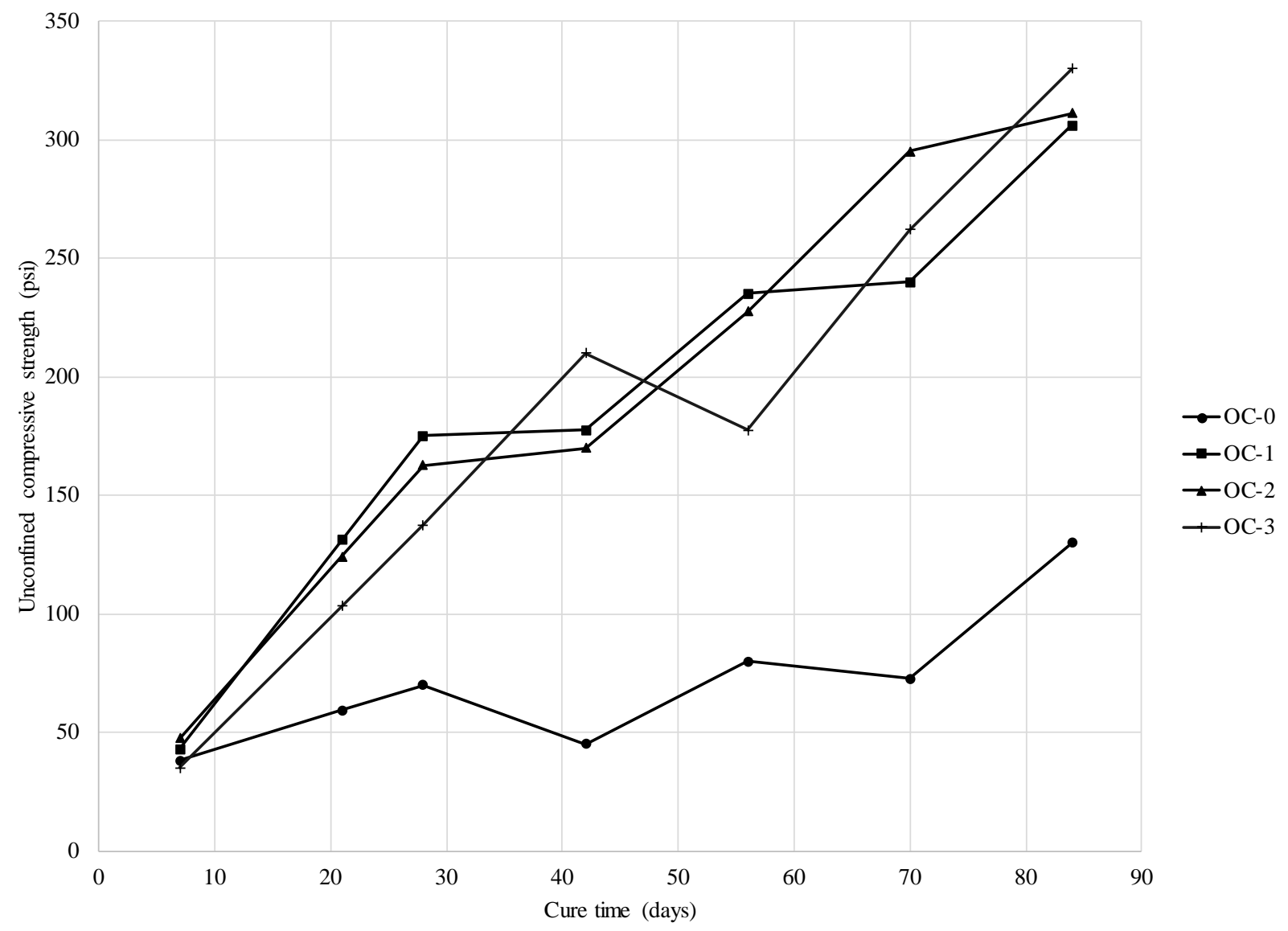

Figure 45 - Unconfined compressive strength with time (OC Samples) 


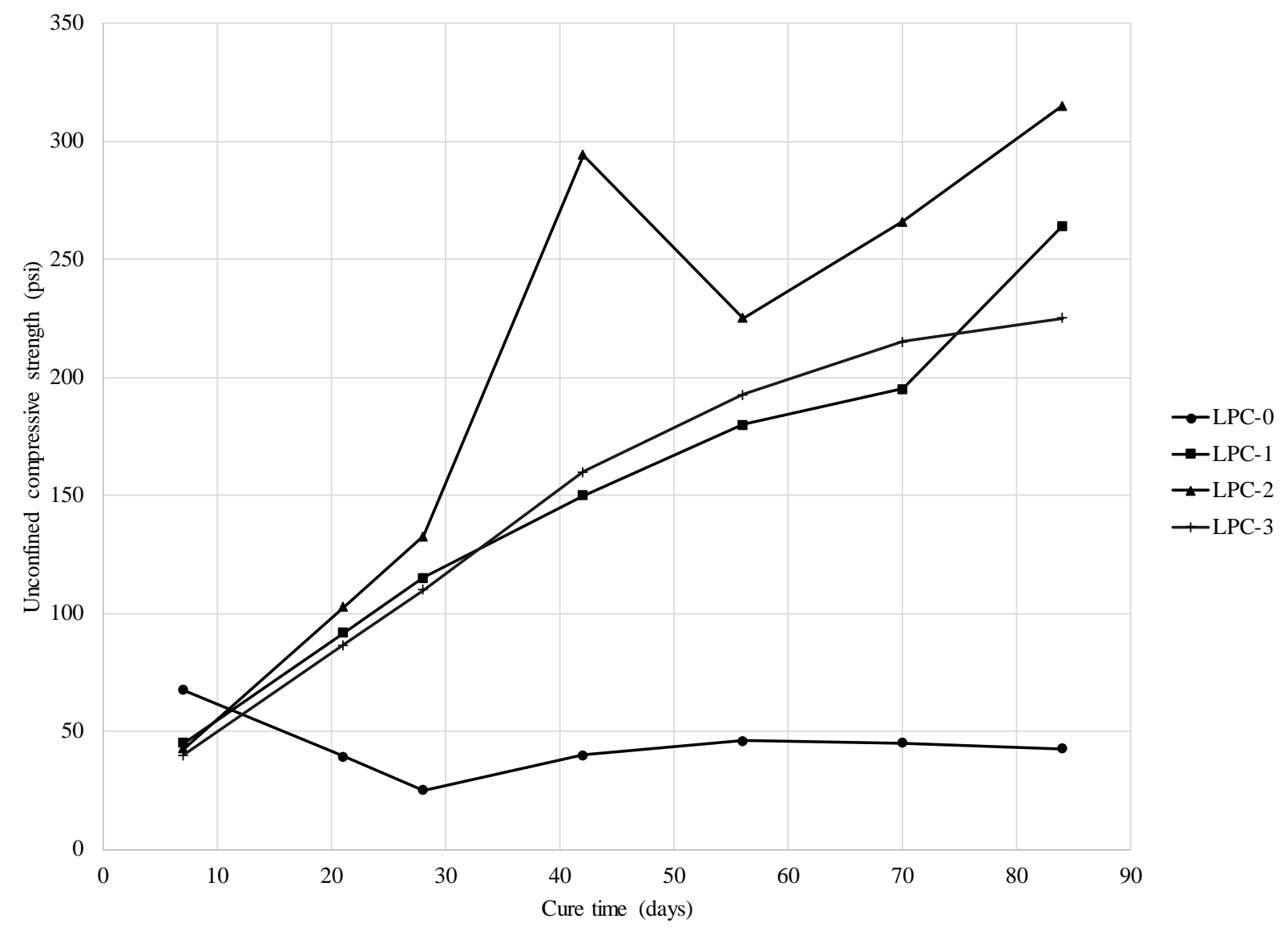

Figure 46 - Unconfined compressive strength with time (LPC Samples) 


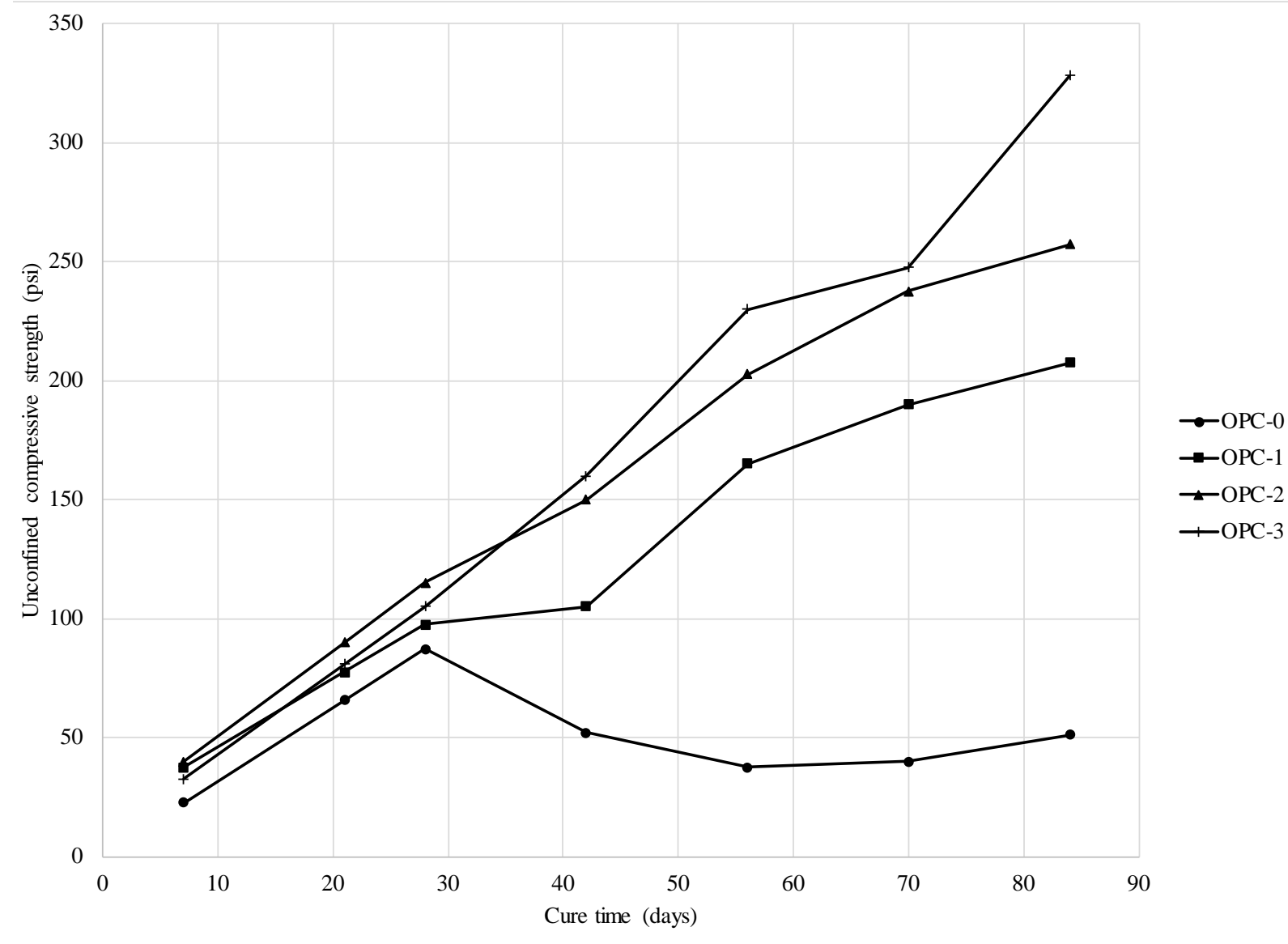

Figure 47 - Unconfined compressive strength with time (OPC Samples) 


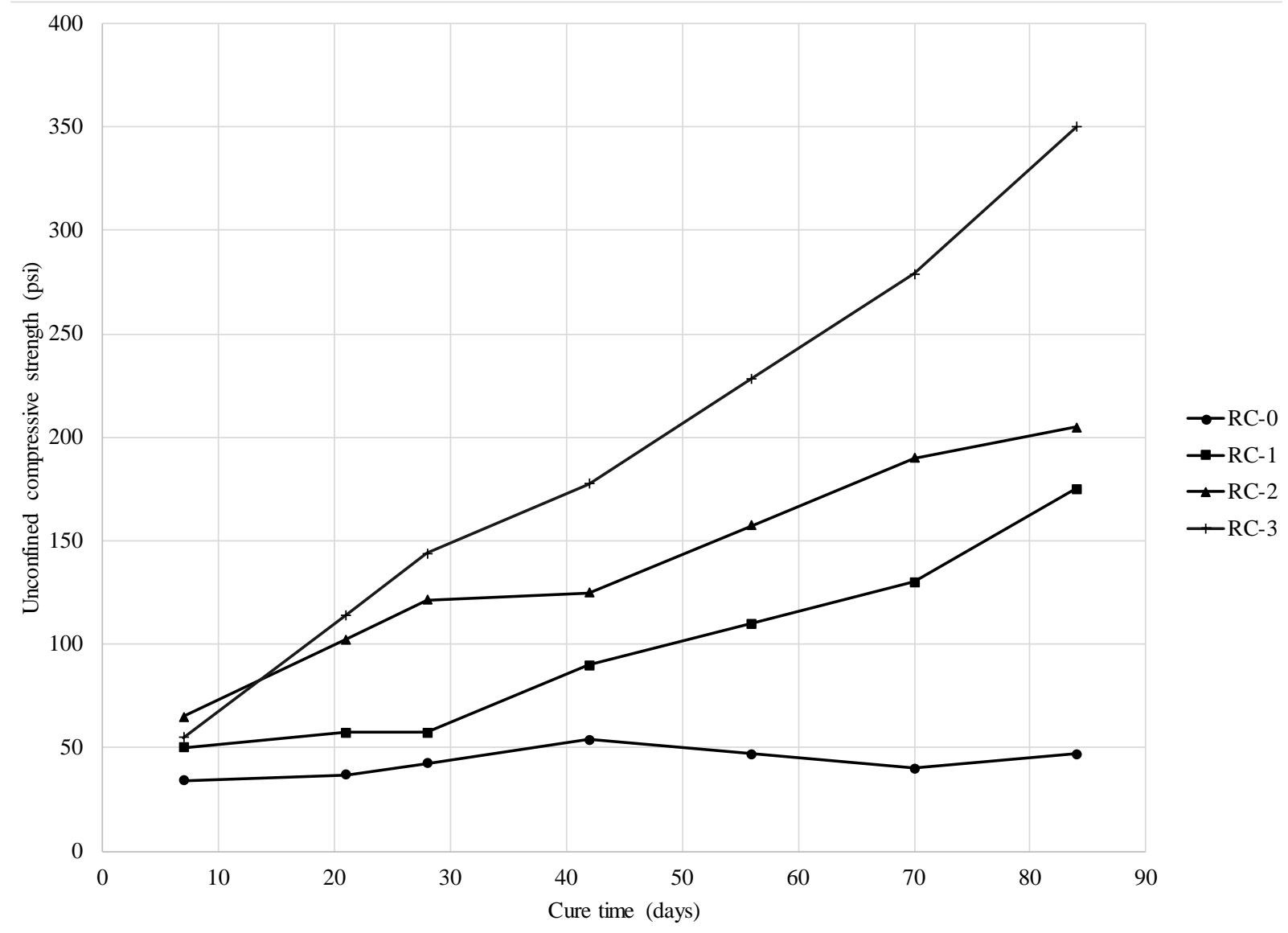

Figure 48 - Unconfined compressive strength with time (RC Samples) 


\subsection{POUR TEST INFORMATION}

Table 26. Gravel materials and slurries applied for pour testing

\begin{tabular}{|c|c|c|}
\hline Material & Justification/Reasoning & \begin{tabular}{|c|}
$\begin{array}{c}\text { Cementitious Mixes Applied } \\
\text { (\% water/pozzolan ratio) }\end{array}$ \\
\end{tabular} \\
\hline M1.0.0 & \multirow{3}{*}{$\begin{array}{c}\text { M1 materials were chosen to determine effect of topical } \\
\text { application on angular gravels. Subsets were chosen to } \\
\text { represent potential trail gradations. }\end{array}$} & \multirow{3}{*}{$50 / 150,60 / 150,70 / 150$} \\
\hline M1.1.0 & & \\
\hline M1.1.1 & & \\
\hline M2.0.0 & \multirow{2}{*}{$\begin{array}{l}\text { M2 materials were chosen to look at the effects of two } \\
\text { layered materials. Subsets were chosen to represent } \\
\text { potential trail gradations. }\end{array}$} & \multirow[b]{2}{*}{$50 / 150,60 / 150,70 / 150$} \\
\hline M2.0.1 & & \\
\hline M3.0.0 & \multirow{2}{*}{$\begin{array}{c}\text { M3 materials were based on the specifications of Montana } \\
\text { trails . M3.0.1 is a direct interpretation of specification } \\
\text { while M3.0.0 includes other sizes to incorporate a higher } \\
\text { number of finer aggregate. }\end{array}$} & \multirow{2}{*}{$50 / 150,60 / 150,70 / 150$} \\
\hline M3.0.1 & & \\
\hline M5.0.1 & $\begin{array}{l}\text { M5.0.1 was based on the subgrade for M3.0.1 to determine } \\
\text { its effectiveness on its own. }\end{array}$ & $50 / 150,60 / 150,70 / 150$ \\
\hline GeoTrail & $\begin{array}{l}\text { Made to mimic the existing gravel used in the trail of } \\
\text { interest on the East end of OIT campus. }\end{array}$ & $50 / 150,60 / 150,70 / 150$ \\
\hline M6.0.0 & $\begin{array}{l}\text { Recreation of C1 with different sizes to illustrate } \\
\text { differences in results based on gravel characteristics. }\end{array}$ & $50 / 150,60 / 150,70 / 150$ \\
\hline \multirow{3}{*}{ C1 } & \multirow{3}{*}{$\begin{array}{c}\text { Initial available coarse gravel. Mostly used for proof-of } \\
\text { concept and process refinement testing as well as possible } \\
\text { trail aggregate. }\end{array}$} & $\begin{array}{l}67 / 100,67 / 900,60 / 100 \\
60 / 150,60 / 233,60 / 400,60 / 900 \\
\text { all with volcanic ash passing } \\
\text { the \#4 sieve. }\end{array}$ \\
\hline & & $\begin{array}{l}\text { 60/100, 60/150, 60/233, } \\
\text { 60/400, 60/900 all with } \\
\text { volcanic ash roughly crushed. }\end{array}$ \\
\hline & & $\begin{array}{l}\text { 60/100, 60/150, 60/233, } \\
\text { 60/400, 60/900 all with } \\
\text { volcanic ash passing the \#200 } \\
\text { sieve. }\end{array}$ \\
\hline
\end{tabular}




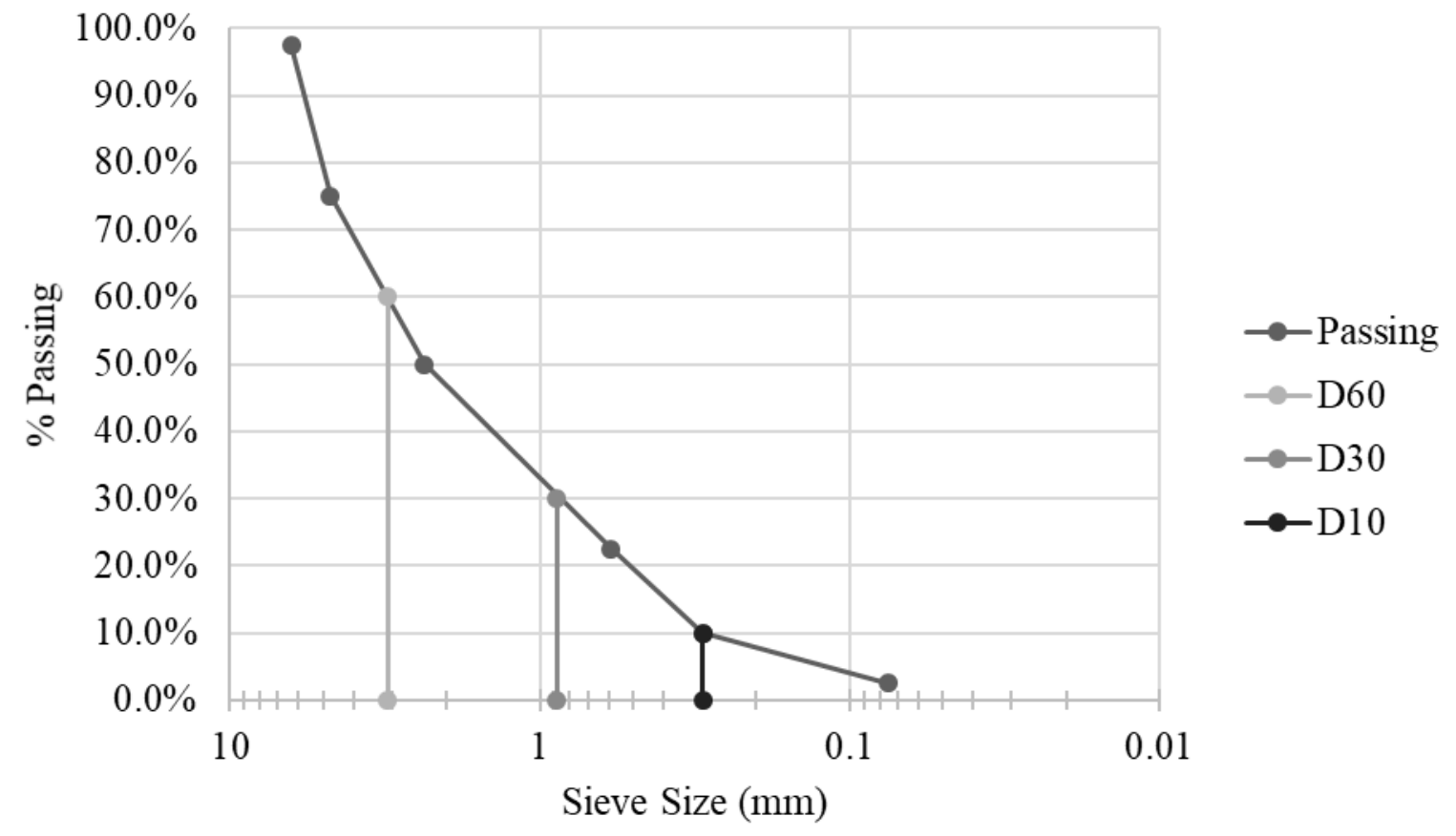

Figure 49 - Gradation of material M1.0.0

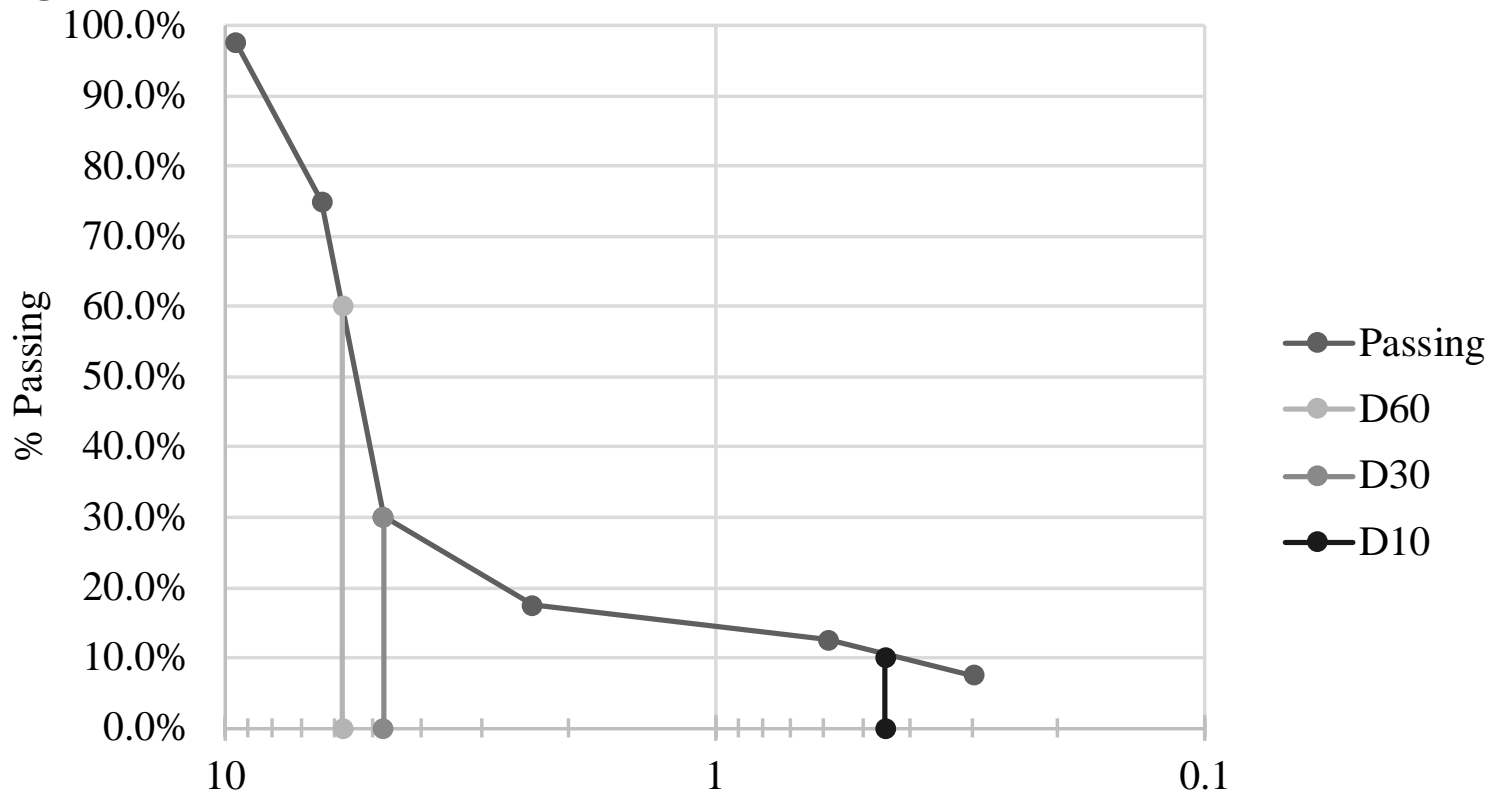

Sieve Size (mm)

Figure 50 - Gradation of material M1.1.0 


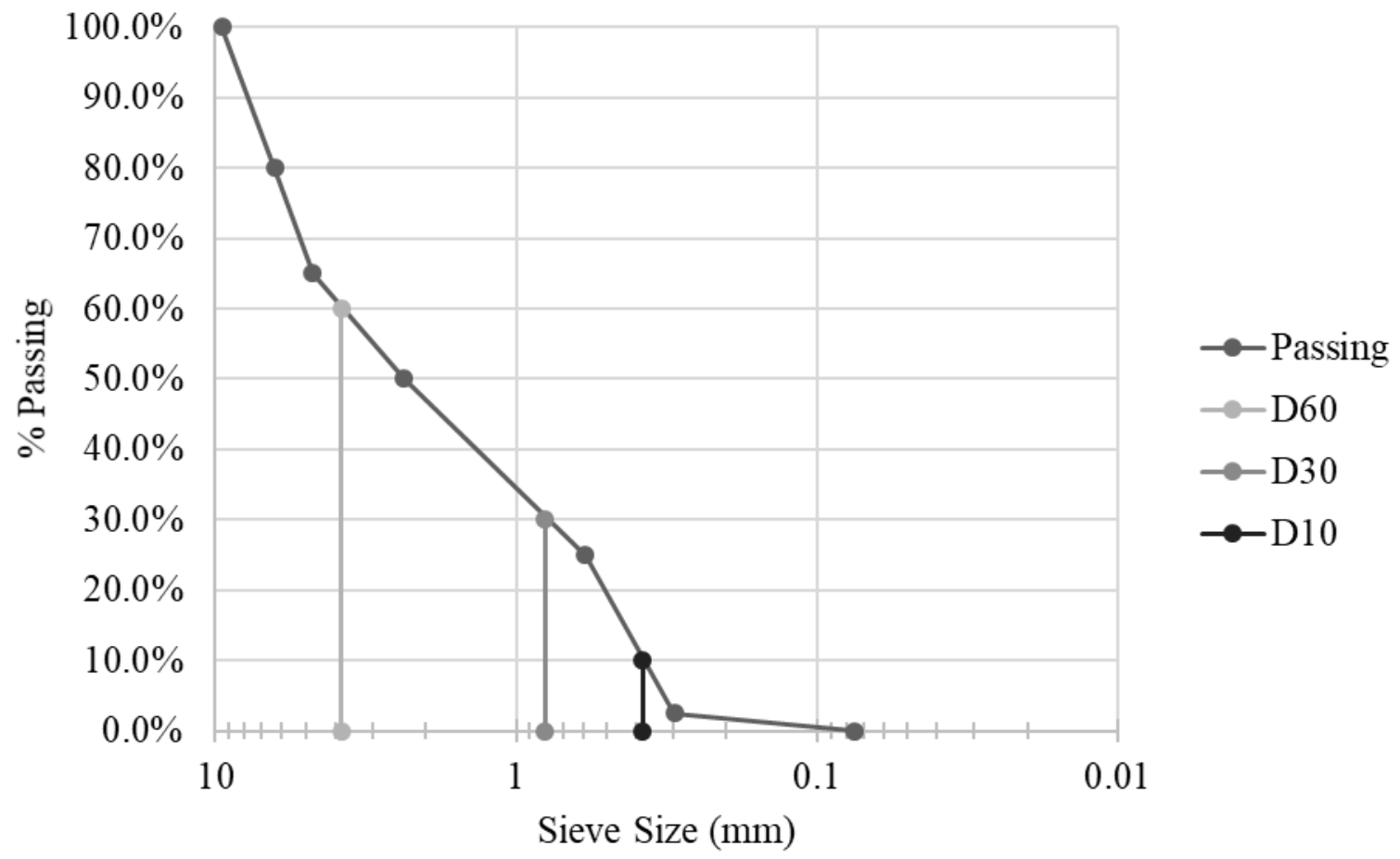

Figure 51 - Gradation of material M1.1.1 


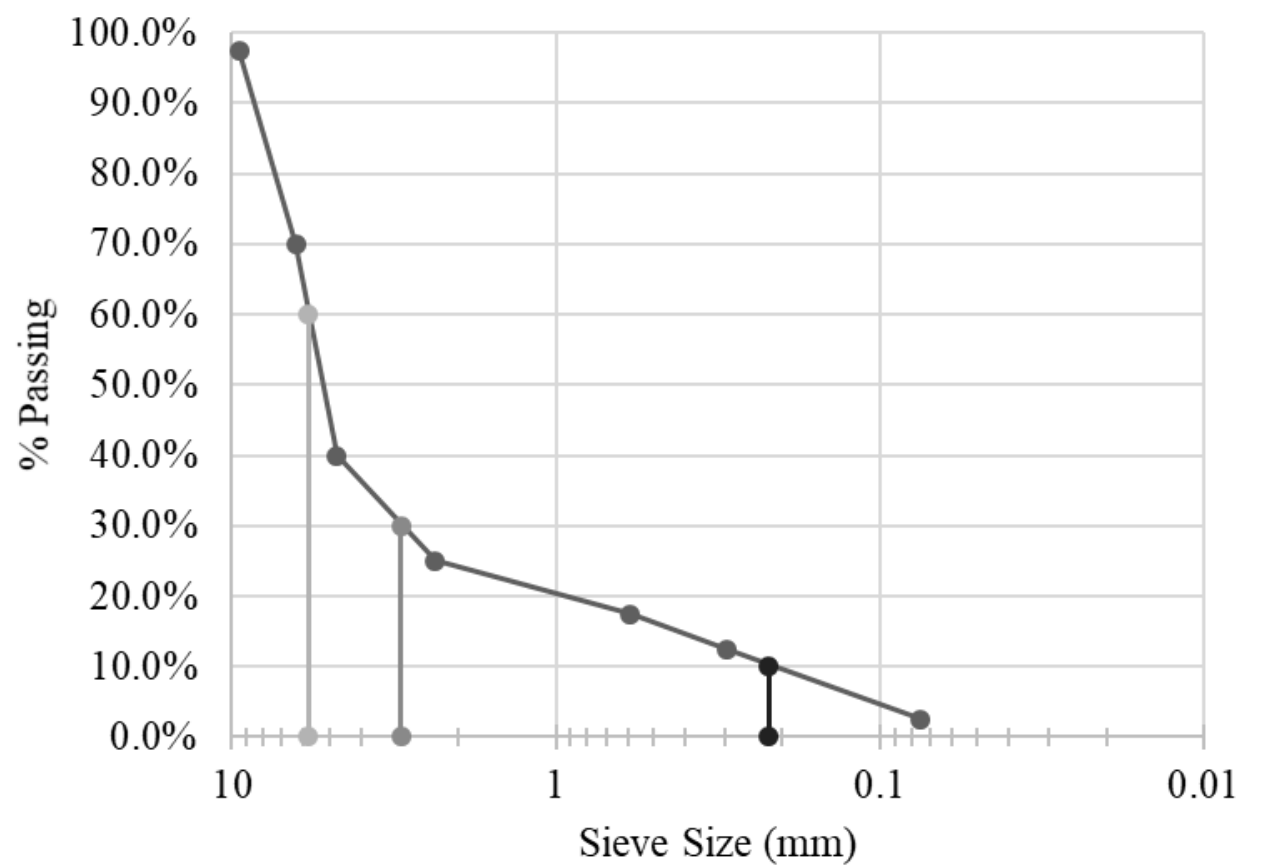

$\rightarrow-$ Passing

$\rightarrow-\mathrm{D} 60$

$\rightarrow-\mathrm{D} 30$

$\rightarrow \mathrm{D} 10$

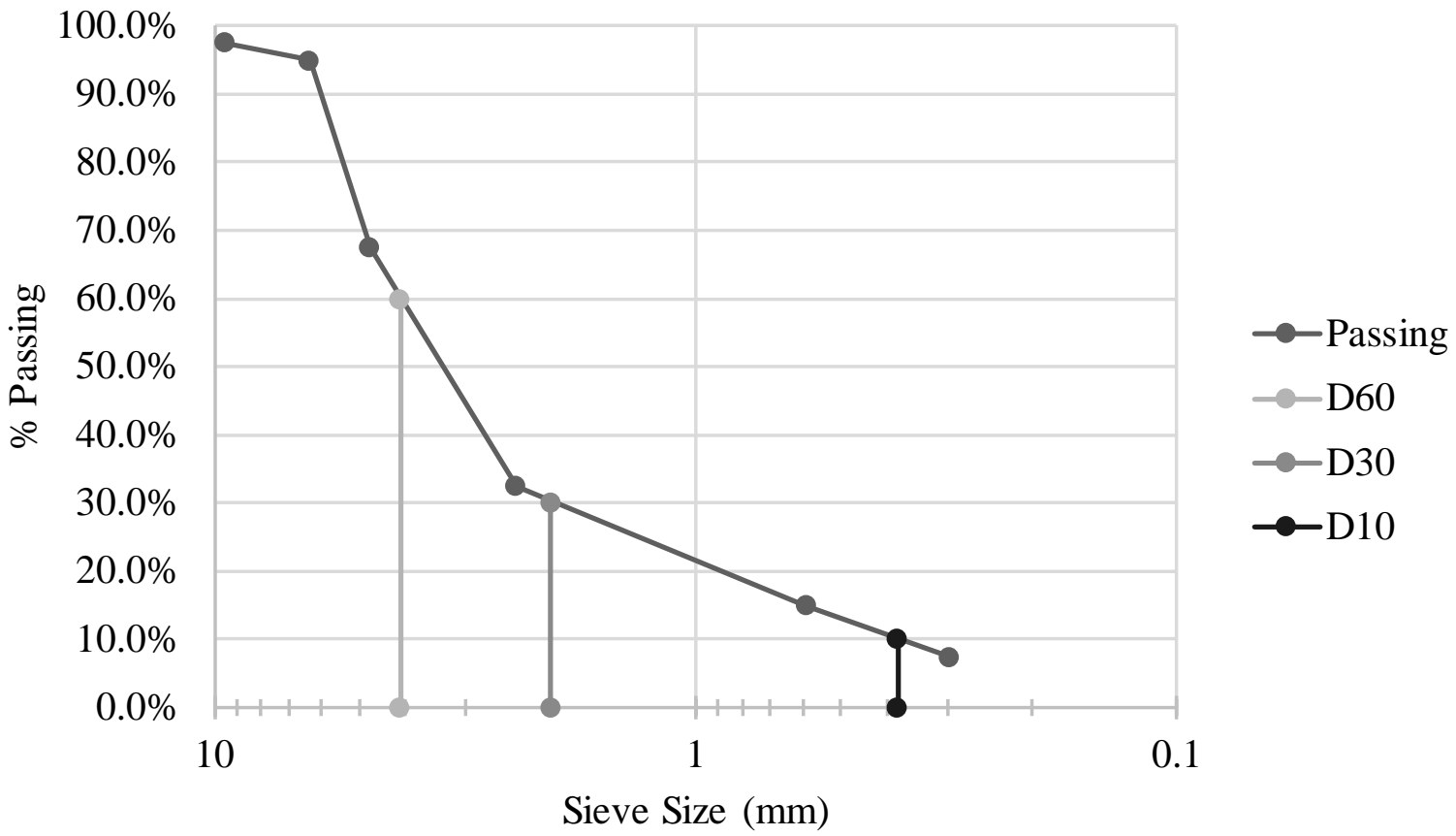

Figure 52 - Gradation of material M2.0.0 - upper $(6.6 \mathrm{~cm})$ and lower $(13.4 \mathrm{~cm})$ layers 

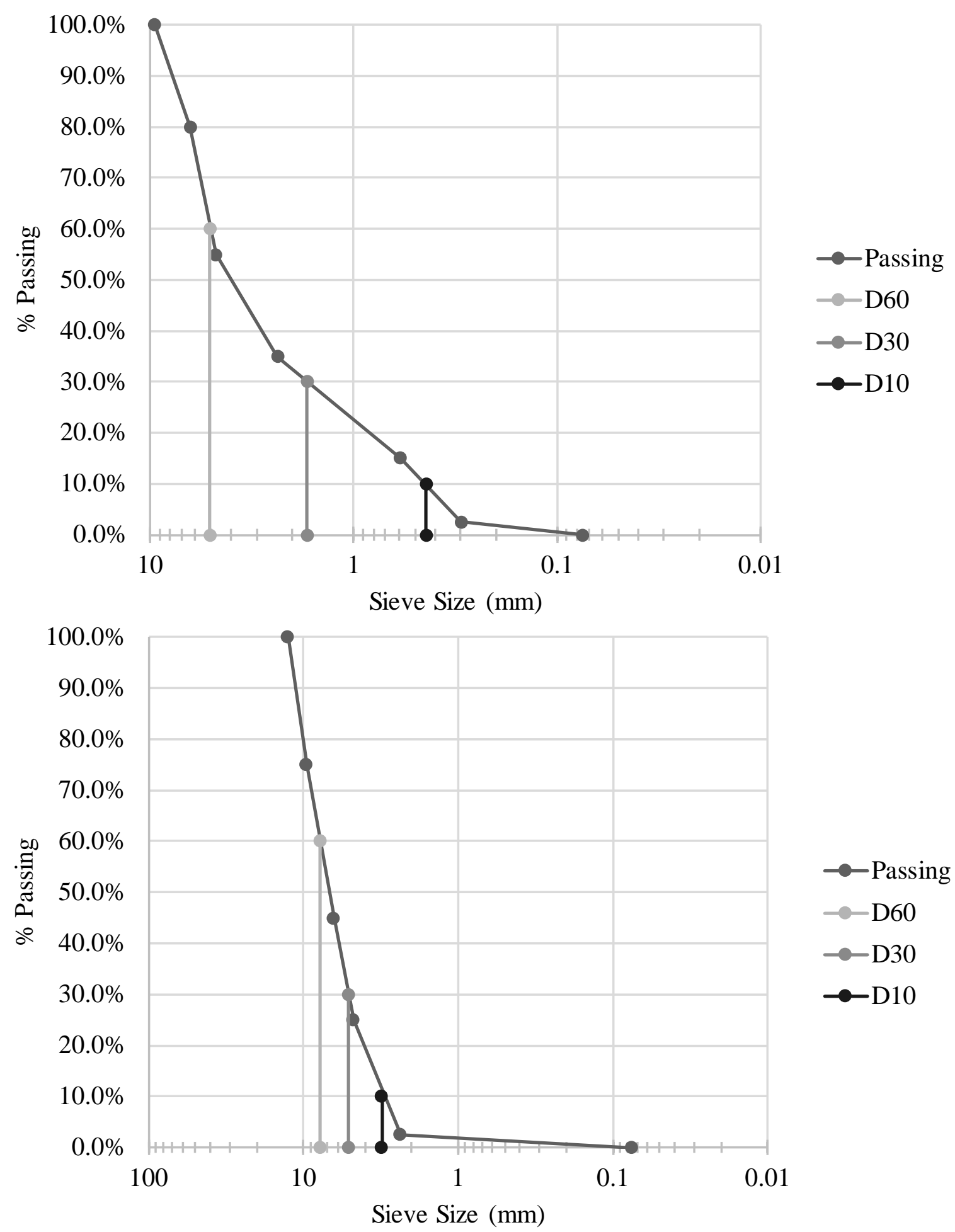

Figure 53 - Gradation of material 2.0.1 upper $(6.6 \mathrm{~cm})$ and lower $(13.4 \mathrm{~cm})$ layers 

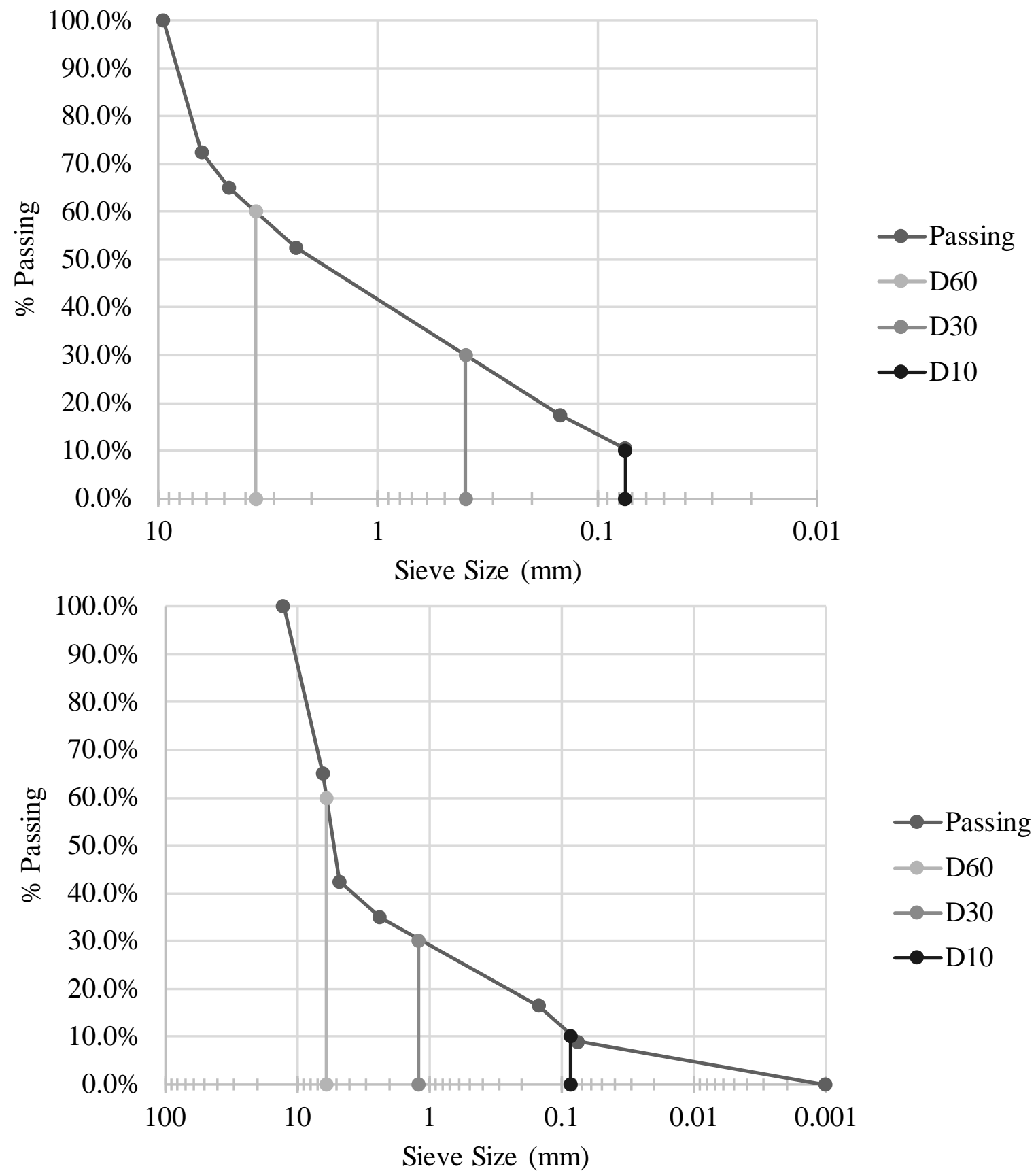

Figure 54 - Gradation of material M 3.0.0 upper $(6.6 \mathrm{~cm})$ and lower $(13.4 \mathrm{~cm})$ layers 

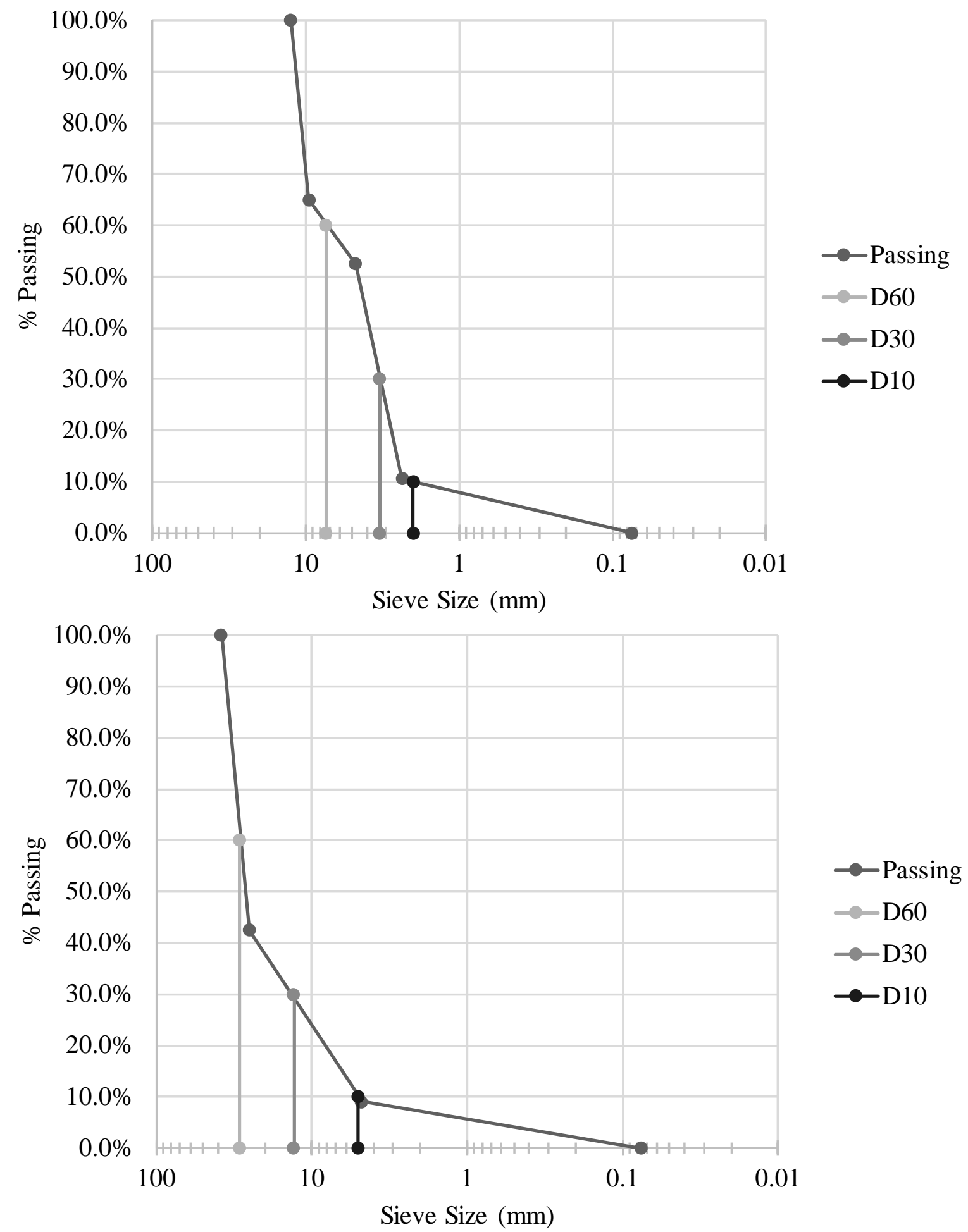

Figure 55 - Gradation of material M 3.0.1 upper $(6.6 \mathrm{~cm})$ and lower $(13.4 \mathrm{~cm})$ layers 


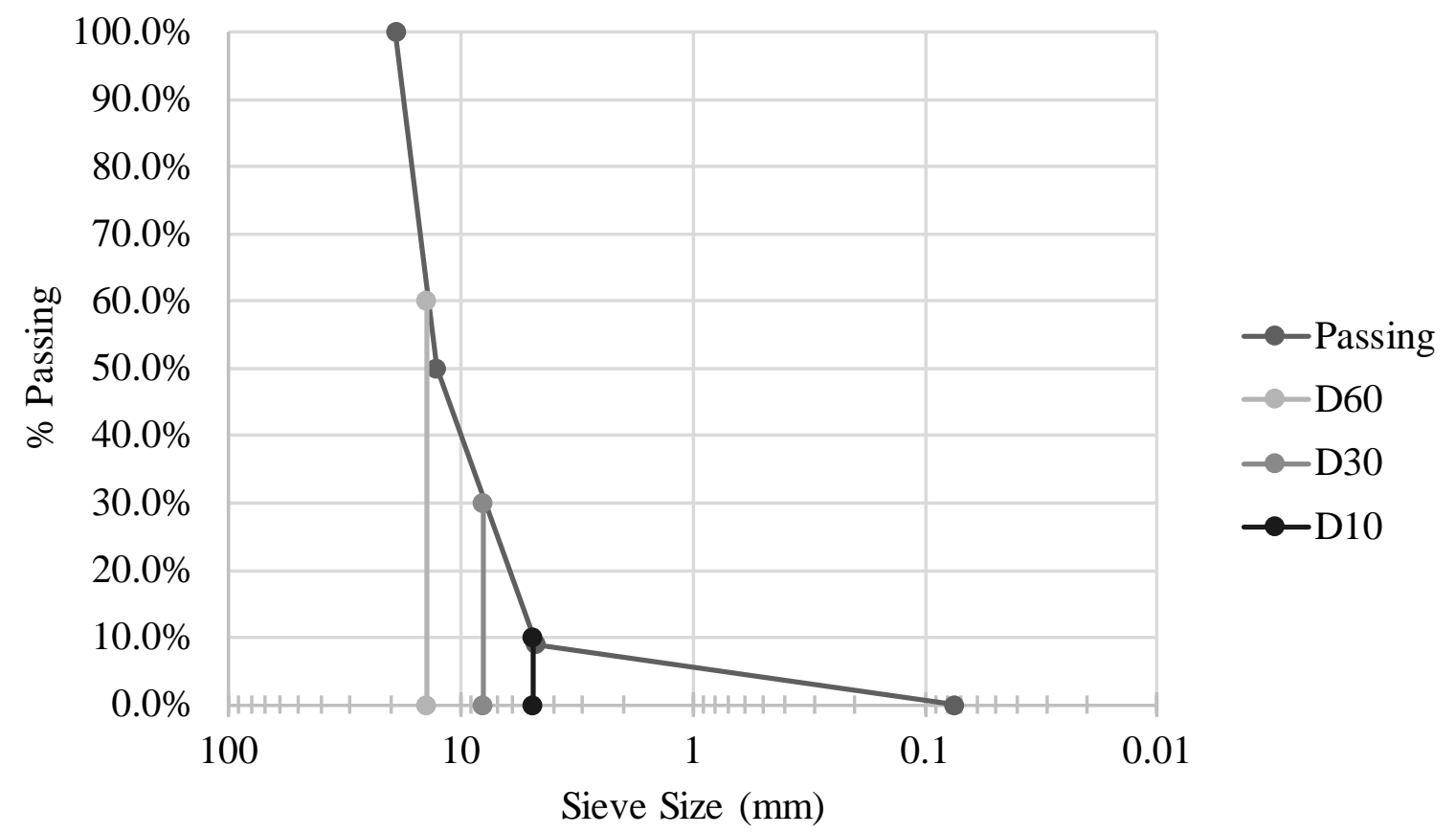

Figure 56 - Gradation of material M 5.0.1

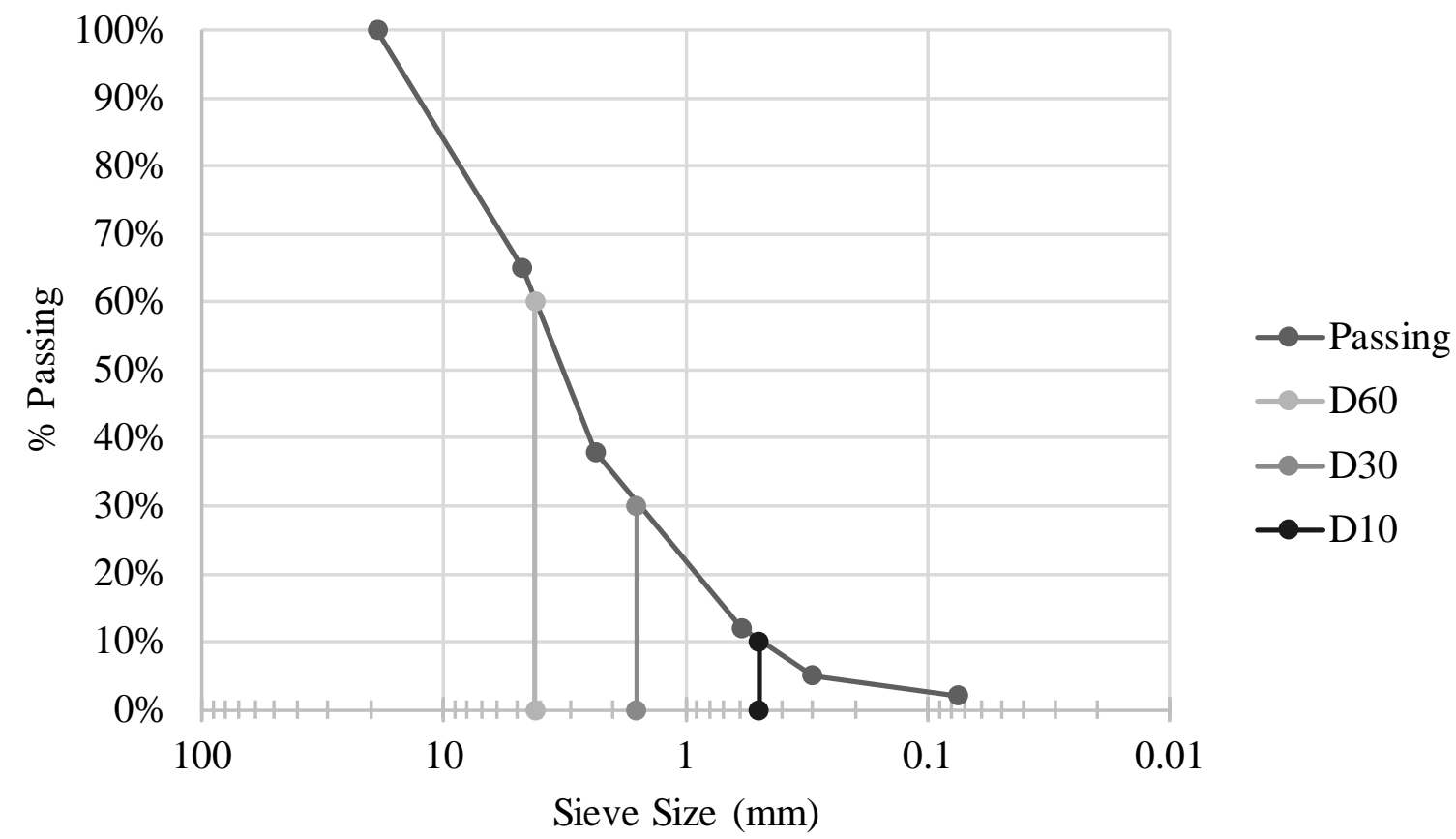

Figure 57 - Gradation of Geotrail material 


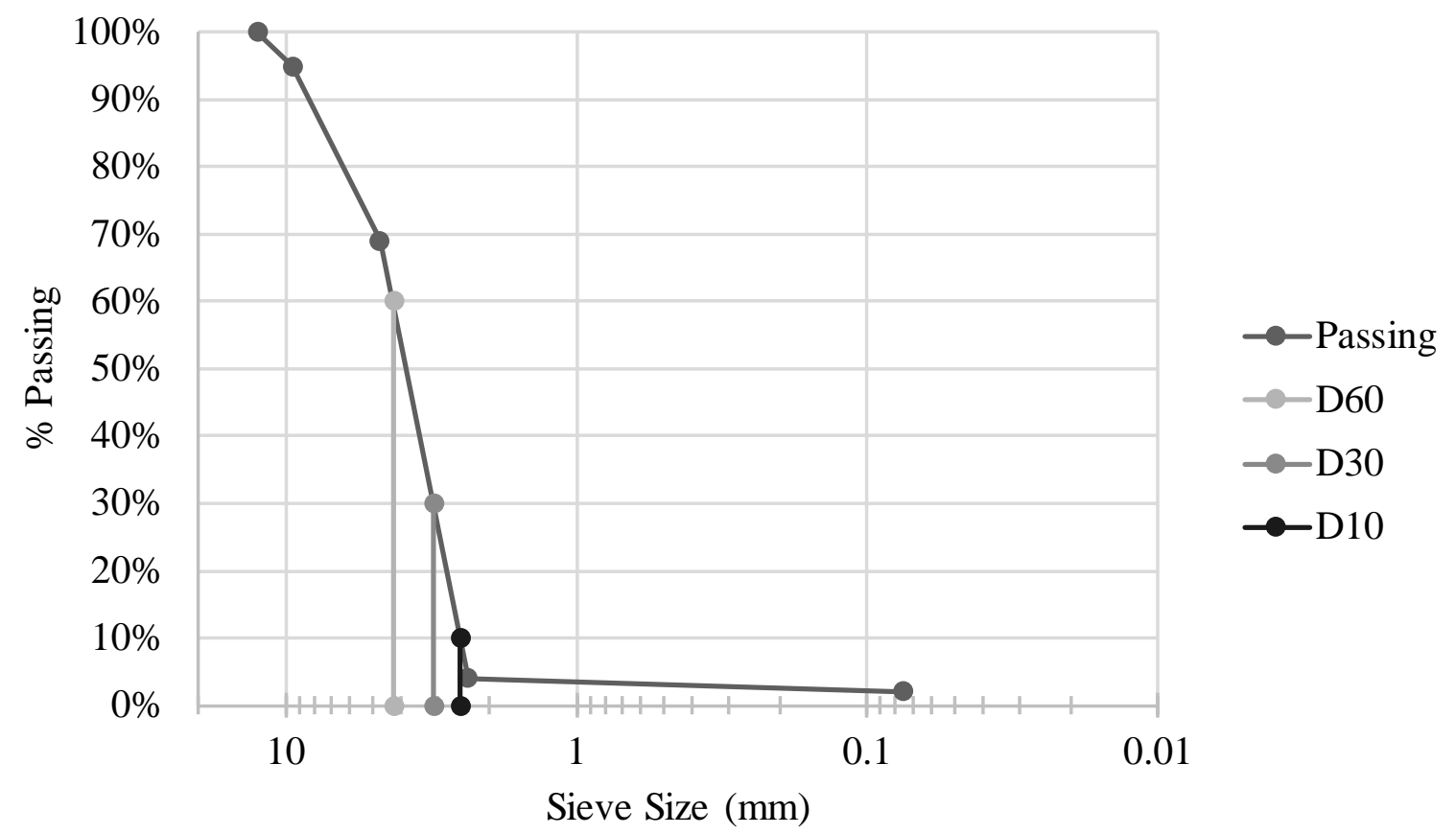

Figure 58 - Gradation of material M 6.0.0

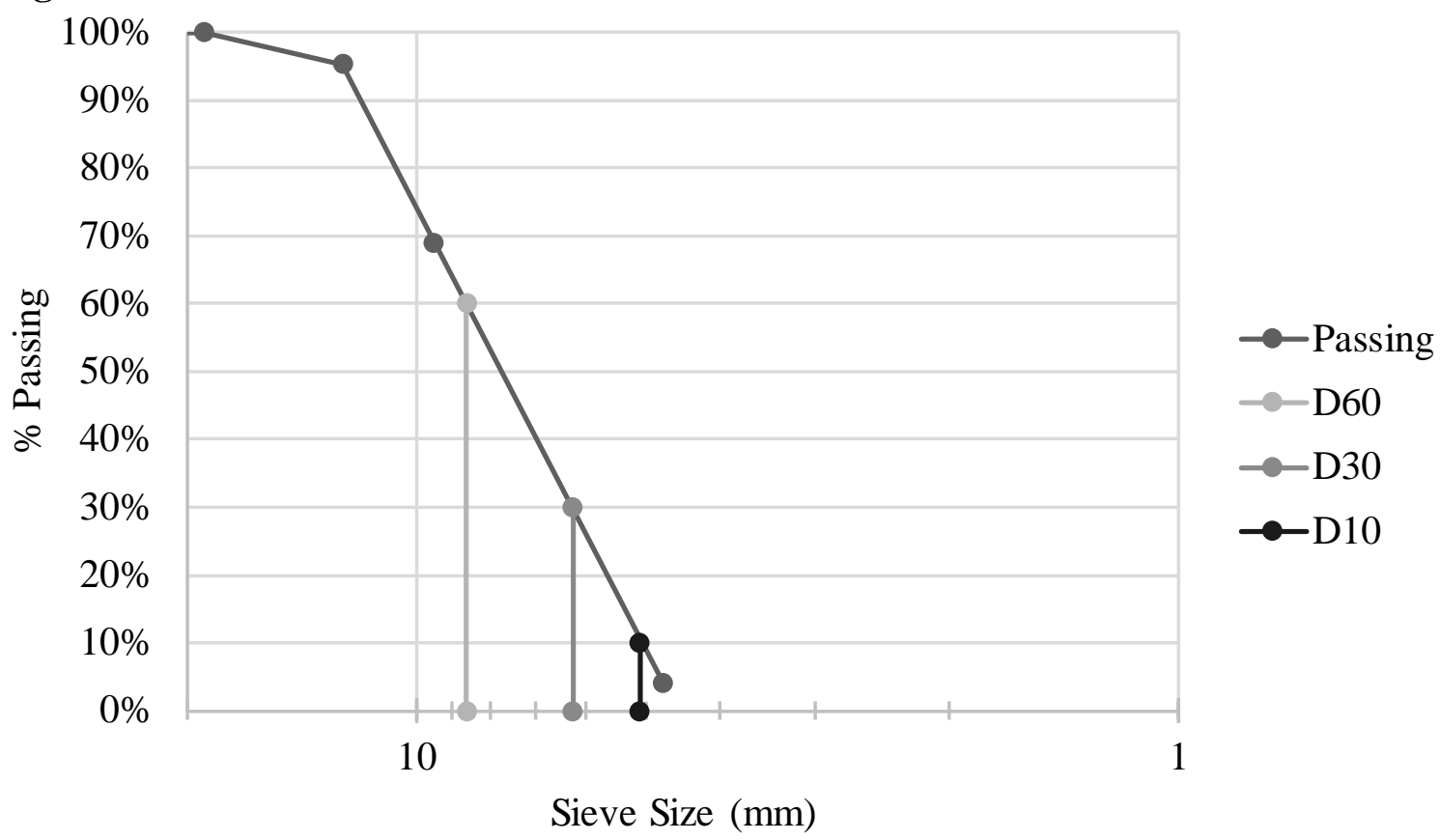

Figure 59 - Gradation of material C1 
Table 27. Pour test results

\begin{tabular}{|c|c|c|c|c|c|c|c|c|c|}
\hline \multicolumn{10}{|c|}{ Material M 1.0.0 } \\
\hline Sample \# & Mold & $\% \mathrm{H} 2 \mathrm{O}$ & \%Pozz & $\%$ PC & Pozz. Ratio & Total Weight (g) & Top weight (g) & Depth (in.) & \%Cemented \\
\hline 1 & 145 & 0.6 & 0.24 & 0.16 & $150 \%$ & 2760.24 & 370.2 & 2.25 & $14 \%$ \\
\hline 2 & 145 & 0.6 & 0.24 & 0.16 & $150 \%$ & 2668.33 & 266.93 & 2.25 & $11 \%$ \\
\hline 3 & 140 & 0.6 & 0.24 & 0.16 & $150 \%$ & 2667.02 & 267.02 & 1.75 & $11 \%$ \\
\hline 1 & 138.87 & 0.7 & 0.18 & 0.12 & $150 \%$ & 2651.83 & 823.54 & 4 & $33 \%$ \\
\hline 2 & 139.04 & 0.7 & 0.18 & 0.12 & $150 \%$ & 2654.14 & 784.96 & 2.75 & $31 \%$ \\
\hline 3 & 143.7 & 0.7 & 0.18 & 0.12 & $150 \%$ & 2658.67 & 826.66 & 2.75 & $33 \%$ \\
\hline 1 & 144.25 & 0.5 & 0.3 & 0.2 & $150 \%$ & 2656.95 & 276.85 & 1.75 & $11 \%$ \\
\hline 2 & 144 & 0.5 & 0.3 & 0.2 & $150 \%$ & 2655.83 & 253.91 & 1.75 & $10 \%$ \\
\hline 3 & 138.68 & 0.5 & 0.3 & 0.2 & $150 \%$ & 2654.45 & 294.05 & 2.5 & $12 \%$ \\
\hline 1 & 156.03 & 0 & G3 & G3 & G3 & 2676.66 & 798.67 & 6.5 & $32 \%$ \\
\hline 2 & 156.56 & 0 & G3 & G3 & G3 & 2677.16 & 1253.67 & 6.5 & $50 \%$ \\
\hline 3 & 161.55 & 0 & G3 & G3 & G3 & 2682.62 & 741.31 & 6.5 & $29 \%$ \\
\hline 1 & 155.9 & 0 & SoilTac & SoilTac & SoilTac & 2737.79 & 485.86 & 6.5 & $19 \%$ \\
\hline 2 & 156.46 & 0 & SoilTac & SoilTac & SoilTac & 2675.83 & 583.85 & 6.5 & $23 \%$ \\
\hline 3 & 161.41 & 0 & SoilTac & SoilTac & SoilTac & 2684.32 & 715.97 & 6.5 & $28 \%$ \\
\hline \multicolumn{10}{|c|}{ Material M 1.1.0 } \\
\hline Sample \# & Mold & \%H2O & \%Pozz & $\% \mathrm{PC}$ & Pozz. Ratio & \begin{tabular}{|l|} 
Total Weight (g) \\
\end{tabular} & Top weight (g) & Depth (in.) & \%Cemented \\
\hline 1 & 145 & 0.6 & 0.24 & 0.16 & $150 \%$ & 2656.65 & 1015.37 & 5 & $40 \%$ \\
\hline 2 & 145 & 0.6 & 0.24 & 0.16 & $150 \%$ & 2657.85 & 1220.5 & 7 & $49 \%$ \\
\hline 3 & 145 & 0.6 & 0.24 & 0.16 & $150 \%$ & 2652.22 & 1234.36 & 6 & $49 \%$ \\
\hline 1 & 160.93 & 0.5 & 0.3 & 0.2 & $150 \%$ & 2677.61 & 938.28 & 6 & $37 \%$ \\
\hline 2 & 156.66 & 0.5 & 0.3 & 0.2 & $150 \%$ & 2671.84 & 901.87 & 5.75 & $36 \%$ \\
\hline 3 & 161.61 & 0.5 & 0.3 & 0.2 & $150 \%$ & 2677.64 & 812.57 & 4.25 & $32 \%$ \\
\hline 1 & 155.5 & 0.7 & 0.18 & 0.12 & $150 \%$ & 2672.45 & 1406.75 & 5 & $56 \%$ \\
\hline 2 & 161.26 & 0.7 & 0.18 & 0.12 & $150 \%$ & 2680.33 & 991.28 & 3.75 & $39 \%$ \\
\hline 3 & 156.07 & 0.7 & 0.18 & 0.12 & $150 \%$ & 2673.58 & 1135.35 & 4.25 & $45 \%$ \\
\hline \multicolumn{10}{|c|}{ Material M 1.1.1 } \\
\hline \begin{tabular}{|l|} 
Sample \# \\
\end{tabular} & Mold & $\% \mathrm{H} 2 \mathrm{O}$ & \%Pozz & $\% \mathrm{PC}$ & Pozz. Ratio & \begin{tabular}{|l|} 
Total Weight (g) \\
\end{tabular} & \begin{tabular}{|l|} 
Top weight (g) \\
\end{tabular} & Depth (in.) & \%Cemented \\
\hline 1 & 145 & 0.6 & 0.24 & 0.16 & $150 \%$ & 2658.51 & 422.36 & 3.5 & $17 \%$ \\
\hline 2 & 145 & 0.6 & 0.24 & 0.16 & $150 \%$ & 2658.39 & 417.79 & 2.75 & $17 \%$ \\
\hline 3 & 140 & 0.6 & 0.24 & 0.16 & $150 \%$ & 2651.51 & 388.67 & 2.25 & $15 \%$ \\
\hline 1 & 140 & 0.5 & 0.3 & 0.2 & $150 \%$ & 2650.26 & 214.83 & 1.75 & $9 \%$ \\
\hline 2 & 145 & 0.5 & 0.3 & 0.2 & $150 \%$ & 2658.08 & 257.47 & 2 & $10 \%$ \\
\hline 3 & 140 & 0.5 & 0.3 & 0.2 & $150 \%$ & 2650.62 & 228.36 & 2 & $9 \%$ \\
\hline 1 & 145 & 0.7 & 0.18 & 0.12 & $150 \%$ & 2657.97 & 342.19 & 2 & $14 \%$ \\
\hline 2 & 145 & 0.7 & 0.18 & 0.12 & $150 \%$ & 2656.86 & 382.58 & 2 & $15 \%$ \\
\hline 3 & 145 & 0.7 & 0.18 & 0.12 & $150 \%$ & 2657.41 & 512.47 & 2.75 & $20 \%$ \\
\hline \multicolumn{10}{|c|}{ Material M 2.0.0 } \\
\hline Sample \# & Mold & $\% \mathrm{H} 2 \mathrm{O}$ & \%Pozz & \%PC & Pozz. Ratio & \begin{tabular}{|l|} 
Total Weight (g) \\
\end{tabular} & Top weight (g) & Depth (in.) & \%Cemented \\
\hline 1 & 145 & 0.60 & 0.24 & 0.16 & $150 \%$ & 2656.82 & 686.01 & 5 & $27 \%$ \\
\hline 2 & 140 & 0.60 & 0.24 & 0.16 & $150 \%$ & 2653.37 & 959.76 & 4 & $38 \%$ \\
\hline 3 & 140 & 0.60 & 0.24 & 0.16 & $150 \%$ & 2652.96 & 582.92 & 4 & $23 \%$ \\
\hline 1 & 161.08 & 0.50 & 0.30 & 0.20 & $150 \%$ & 2696.53 & 522.75 & 2 & $21 \%$ \\
\hline 2 & 156.3 & 0.50 & 0.30 & 0.20 & $150 \%$ & 2693.35 & 576.37 & 2 & $23 \%$ \\
\hline 3 & 156.11 & 0.50 & 0.30 & 0.20 & $150 \%$ & 2691.82 & 594.33 & 2 & $23 \%$ \\
\hline 1 & 156.57 & 0.70 & 0.18 & 0.12 & $150 \%$ & 2695.28 & 0 & 0 & $0 \%$ \\
\hline 2 & 161.2 & 0.70 & 0.18 & 0.12 & $150 \%$ & 2697.11 & 339.13 & 1.75 & $13 \%$ \\
\hline 3 & 161.74 & 0.70 & 0.18 & 0.12 & $150 \%$ & 2699.28 & 371.47 & 2 & $15 \%$ \\
\hline \multicolumn{10}{|c|}{ Material M 2.0.1 } \\
\hline Sample \# & Mold & $\% \mathrm{H} 2 \mathrm{O}$ & \%Pozz & \%PC & Pozz. Ratio & \begin{tabular}{|l|} 
Total Weight (g) \\
\end{tabular} & Top weight (g) & Depth (in.) & \%Cemented \\
\hline 1 & 145 & 0.60 & 0.24 & 0.16 & $150 \%$ & 2659.21 & 753.77 & 5.5 & $30 \%$ \\
\hline 2 & 140 & 0.60 & 0.24 & 0.16 & $150 \%$ & 2653 & 797.61 & 4 & $32 \%$ \\
\hline 3 & 145 & 0.60 & 0.24 & 0.16 & $150 \%$ & 2657.71 & 888.15 & 5.5 & $35 \%$ \\
\hline 1 & 140 & 0.50 & 0.30 & 0.20 & $150 \%$ & 2655.53 & 495.7 & 4.5 & $20 \%$ \\
\hline 2 & 145 & 0.50 & 0.30 & 0.20 & $150 \%$ & 2656.74 & 597.7 & 6.5 & $24 \%$ \\
\hline 3 & 145 & 0.50 & 0.30 & 0.20 & $150 \%$ & 2660.97 & 540.9 & 4.5 & $21 \%$ \\
\hline 1 & 145 & 0.70 & 0.18 & 0.12 & $150 \%$ & 2658.52 & 833.88 & 4 & $33 \%$ \\
\hline 2 & 140 & 0.70 & 0.18 & 0.12 & $150 \%$ & 2653.32 & 1053.41 & 4 & $42 \%$ \\
\hline 3 & 140 & 0.70 & 0.18 & 0.12 & $150 \%$ & 2653.12 & 979.83 & 4.5 & $39 \%$ \\
\hline
\end{tabular}


Table 28. Pour test results continued

\begin{tabular}{|c|c|c|c|c|c|c|c|c|c|}
\hline \multicolumn{10}{|c|}{ Material M 3.0.0 } \\
\hline Sample \# & Mold & \%H2O & \%Pozz & $\% \mathrm{PC}$ & Pozz. Ratio & Total Weight (g) & \begin{tabular}{|l|} 
Top weight (g) \\
\end{tabular} & Depth (in.) & \%Cemented \\
\hline 1 & 145 & 0.60 & 0.24 & 0.16 & $150 \%$ & 2658.9 & 766.11 & 4.5 & $30 \%$ \\
\hline 2 & 140 & 0.60 & 0.24 & 0.16 & $150 \%$ & 2654.4 & 1052.38 & 4.75 & $42 \%$ \\
\hline 3 & 145 & 0.60 & 0.24 & 0.16 & $150 \%$ & 2658.96 & 823.13 & 4.5 & $33 \%$ \\
\hline 1 & 160.9 & 0.50 & 0.30 & 0.20 & $150 \%$ & 2675.52 & 606.47 & 2.25 & $24 \%$ \\
\hline 2 & 156.5 & 0.50 & 0.30 & 0.20 & $150 \%$ & 2676.54 & 610.76 & 2 & $24 \%$ \\
\hline 3 & 156 & 0.50 & 0.30 & 0.20 & $150 \%$ & 2669.8 & 624.81 & 2.5 & $25 \%$ \\
\hline 1 & 155.54 & 0.70 & 0.18 & 0.12 & $150 \%$ & 2674.66 & 167.46 & 0.75 & $7 \%$ \\
\hline 2 & 161.36 & 0.70 & 0.18 & 0.12 & $150 \%$ & 2680.24 & 204.36 & 0.75 & $8 \%$ \\
\hline 3 & 161.11 & 0.70 & 0.18 & 0.12 & $150 \%$ & 2676.23 & 190.26 & 0.75 & $8 \%$ \\
\hline \multicolumn{10}{|c|}{ Material M 3.0.1 } \\
\hline Sample \# & Mold & \%H2O & \%Pozz & $\% \mathrm{PC}$ & Pozz. Ratio & Total Weight (g) & \begin{tabular}{|l|} 
Top weight (g) \\
\end{tabular} & Depth (in.) & \%Cemented \\
\hline 1 & 140 & 0.60 & 0.24 & 0.16 & $150 \%$ & 2653.36 & 1262.88 & 5 & $50 \%$ \\
\hline 2 & 140 & 0.60 & 0.24 & 0.16 & $150 \%$ & 2653.58 & 1156.16 & 4 & $46 \%$ \\
\hline 3 & 140 & 0.60 & 0.24 & 0.16 & $150 \%$ & 2653.84 & 1069.54 & 4.75 & $43 \%$ \\
\hline 1 & 145 & 0.50 & 0.30 & 0.20 & $150 \%$ & 2660.54 & 817.62 & 4.5 & $33 \%$ \\
\hline 2 & 145 & 0.50 & 0.30 & 0.20 & $150 \%$ & 2731.4 & 950.83 & 4 & $37 \%$ \\
\hline 3 & 140 & 0.50 & 0.30 & 0.20 & $150 \%$ & 2664.24 & 667.57 & 4 & $26 \%$ \\
\hline 1 & 156.28 & 0.70 & 0.18 & 0.12 & $150 \%$ & 2674.85 & 553 & 2 & $22 \%$ \\
\hline 2 & 156.2 & 0.70 & 0.18 & 0.12 & $150 \%$ & 2674.85 & 558.16 & 2.5 & $22 \%$ \\
\hline 3 & 155.74 & 0.70 & 0.18 & 0.12 & $150 \%$ & 2676.95 & 442.72 & 1.75 & $18 \%$ \\
\hline \multicolumn{10}{|c|}{ Material M 5.0.1 } \\
\hline Sample \# & Mold & $\% \mathrm{H} 2 \mathrm{O}$ & \%Pozz & \%PC & \begin{tabular}{|l|} 
Pozz. Ratio \\
\end{tabular} & Total Weight (g) & \begin{tabular}{|l|} 
Top weight (g) \\
\end{tabular} & Depth (in.) & \%Cemented \\
\hline 1 & 140 & 0.60 & 0.24 & 0.16 & $150 \%$ & 2615.11 & 1638.59 & 7 & $66 \%$ \\
\hline 2 & 140 & 0.60 & 0.24 & 0.16 & $150 \%$ & 2650.02 & 1448.45 & 6.25 & $58 \%$ \\
\hline 3 & 145 & 0.60 & 0.24 & 0.16 & $150 \%$ & 2660.35 & 1554.89 & 5.5 & $62 \%$ \\
\hline 1 & 140 & 0.50 & 0.30 & 0.20 & $150 \%$ & 2650.7 & 470.04 & 1.75 & $19 \%$ \\
\hline 2 & 140 & 0.50 & 0.30 & 0.20 & $150 \%$ & 2656.58 & 872.64 & 3.5 & $35 \%$ \\
\hline 3 & 145 & 0.50 & 0.30 & 0.20 & $150 \%$ & 2655.85 & 873.1 & 3.5 & $35 \%$ \\
\hline 1 & 140 & 0.70 & 0.18 & 0.12 & $150 \%$ & 2656.89 & 367.02 & 1.75 & $15 \%$ \\
\hline 2 & 145 & 0.70 & 0.18 & 0.12 & $150 \%$ & 2660.38 & 1157.48 & 4 & $46 \%$ \\
\hline 3 & 145 & 0.70 & 0.18 & 0.12 & $150 \%$ & 2659.6 & 1038.9 & 4.5 & $41 \%$ \\
\hline \multicolumn{10}{|c|}{ Material M 6.0.0 } \\
\hline Sample \# & Mold & $\% \mathrm{H} 2 \mathrm{O}$ & \%Pozz & $\% \mathrm{PC}$ & \begin{tabular}{|l|} 
Pozz. Ratio \\
\end{tabular} & Total Weight (g) & \begin{tabular}{|l|} 
Top weight (g) \\
\end{tabular} & Depth (in.) & \%Cemented \\
\hline 1 & 139.3 & 0.60 & 0.24 & 0.16 & $150 \%$ & 2392.15 & 257.84 & 3 & $11 \%$ \\
\hline 2 & 139.3 & 0.60 & 0.24 & 0.16 & $150 \%$ & 2368.05 & 91.85 & 2 & $4 \%$ \\
\hline 3 & 139.3 & 0.60 & 0.24 & 0.16 & $150 \%$ & 2524.77 & 122.86 & 2 & $5 \%$ \\
\hline 1 & 140 & 0.50 & 0.30 & 0.20 & $150 \%$ & 2628.56 & 463.75 & 3.75 & $19 \%$ \\
\hline 2 & 140 & 0.50 & 0.30 & 0.20 & $150 \%$ & 2654.9 & 449.51 & 2.75 & $18 \%$ \\
\hline 3 & 145 & 0.50 & 0.30 & 0.20 & $150 \%$ & 2661.55 & 489.97 & 2 & $19 \%$ \\
\hline 1 & 145 & 0.70 & 0.18 & 0.12 & $150 \%$ & 2659.61 & 439.78 & 2 & $17 \%$ \\
\hline 2 & 145 & 0.70 & 0.18 & 0.12 & $150 \%$ & 2661.04 & 490.06 & 3 & $19 \%$ \\
\hline 3 & 145 & 0.70 & 0.18 & 0.12 & $150 \%$ & 2659.26 & 438.14 & 3 & $17 \%$ \\
\hline
\end{tabular}


Table 29. Pour test results continued

\begin{tabular}{|c|c|c|c|c|c|c|c|c|c|}
\hline \multicolumn{10}{|c|}{ Material C1 } \\
\hline Sample \# & Mold & \%H2O & \%Pozz & \%PC & Pozz. Ratio & Total Weight (g) & Top weight (g) & Depth (in.) & \%Cemented \\
\hline OC1 & 140 & 0.6 & $240 c \%$ & 0.16 & $150 \%$ oc & 2356.87 & 0 & 0 & $0 \%$ \\
\hline OC2 & 145 & 0.6 & $240 c \%$ & 0.16 & $150 \%$ oc & 2416.9 & 0 & 0 & $0 \%$ \\
\hline OC3 & 145 & 0.6 & $240 c \%$ & 0.16 & $150 \%$ oc & 2409.93 & 96.9 & 1.25 & $4 \%$ \\
\hline Poz4-1 & 110 & 0.6 & $20 \# 4 \%$ & 0.2 & $100 \% \# 4$ & 2178.6 & 657.1 & 4 & $32 \%$ \\
\hline Poz4-2 & 110 & 0.6 & $24 \# 4 \%$ & 0.16 & $150 \% \# 4$ & 2306.9 & 689.6 & 3.25 & $31 \%$ \\
\hline Poz4-3 & 110 & 0.6 & $28 \# 4 \%$ & 0.12 & $233 \% \# 4$ & 2270.5 & 266.1 & 2 & $12 \%$ \\
\hline Poz4-4 & 110 & 0.6 & $32 \# 4 \%$ & 0.08 & $400 \% \# 4$ & 2258.6 & 152.8 & 1.5 & $7 \%$ \\
\hline Poz4-5 & 110 & 0.6 & $36 \# 4 \%$ & 0.04 & $900 \% \# 4$ & 2312.6 & 0 & 0 & $0 \%$ \\
\hline PozCrush-1 & 110 & 0.6 & 20 crush\% & 0.2 & $100 \%$ crush & 2454.79 & 488.34 & 3 & $21 \%$ \\
\hline PozCrush-2 & 110 & 0.6 & 24 crush\% & 0.16 & $150 \% c r u s h$ & 2127.1 & 1056.64 & 5.5 & $52 \%$ \\
\hline PozCrush-3 & 110 & 0.6 & 28 crush\% & 0.12 & $233 \%$ crush & 2361.19 & 646.45 & 4 & $29 \%$ \\
\hline PozCrush-4 & 110 & 0.6 & 32 crush\% & 0.08 & $400 \% c r u s h$ & 2247.6 & 356.44 & 3.5 & $17 \%$ \\
\hline PozCrush-5 & 110 & 0.6 & 36 crush\% & 0.04 & $900 \% c r u s h$ & 2279.44 & 137.16 & 1.5 & $6 \%$ \\
\hline Poz200-1 & 110 & 0.6 & $20-200 \%$ & 0.2 & $100 \%-200$ & 2251.9 & 865.66 & 6 & $40 \%$ \\
\hline Poz200-2 & 110 & 0.6 & $24-200 \%$ & 0.16 & $150 \%-200$ & 2261.3 & 1358.95 & 6.5 & $63 \%$ \\
\hline Poz200-3 & 110 & 0.6 & $28-200 \%$ & 0.12 & $233 \%-200$ & 2167.03 & 1034 & 6.5 & $50 \%$ \\
\hline Poz200-4 & 110 & 0.6 & $32-200 \%$ & 0.08 & $400 \%-200$ & 2281.12 & 855.54 & 4.5 & $39 \%$ \\
\hline Poz200-5 & 110 & 0.6 & $36-200 \%$ & 0.04 & $900 \%-200$ & 2212.37 & 780.52 & 4.5 & $37 \%$ \\
\hline PozCrush6 & 110 & 0.67 & 20 crush\% & 0.2 & $100 \% c r u s h$ & 2305.9 & 198.6 & 1.5 & $9 \%$ \\
\hline PozCrush7 & 110 & 0.67 & 36 crush\% & 0.04 & $900 \%$ crush & 1921.8 & 0 & 0 & $0 \%$ \\
\hline Lined 1 & 161.25 & 0.6 & 24 lined\% & 0.16 & $150 \%$ lined & 2194.72 & 0 & 0 & $0 \%$ \\
\hline Lined 2 & 160.79 & 0.6 & 24 lined\% & 0.16 & $150 \%$ lined & 2217.04 & 922.21 & 4.75 & $45 \%$ \\
\hline Lined 3 & 156.6 & 0.6 & 24 lined\% & 0.16 & $150 \%$ lined & 2312.2 & 663.57 & 4.75 & $31 \%$ \\
\hline
\end{tabular}


Table 30. Pour test results continued

\begin{tabular}{|c|c|c|c|c|c|c|c|c|c|}
\hline \multicolumn{10}{|c|}{ Material GeoTrail } \\
\hline Sample \# & Mold & $\% \mathrm{H} 2 \mathrm{O}$ & $\%$ Pozz & $\%$ PC & Pozz. Ratio & Total Weight (g) & Top weight (g) & Depth (in.) & \%Cemented \\
\hline 1 & 145 & 0.6 & 0.24 & 0.16 & $150 \%$ & 2706.53 & 735.32 & 4 & $29 \%$ \\
\hline 2 & 140 & 0.6 & 0.24 & 0.16 & $150 \%$ & 2560.49 & 787.75 & 4.5 & $33 \%$ \\
\hline 3 & 145 & 0.6 & 0.24 & 0.16 & $150 \%$ & 2559.1 & 827.66 & 4.5 & $34 \%$ \\
\hline 1 & 161.38 & 0.5 & 0.3 & 0.2 & $150 \%$ & 2674.95 & 364.16 & 2 & $14 \%$ \\
\hline 2 & 156.04 & 0.5 & 0.3 & 0.2 & $150 \%$ & 2670.18 & 301.88 & 1.75 & $12 \%$ \\
\hline 3 & 160.74 & 0.5 & 0.3 & 0.2 & $150 \%$ & 2674.71 & 377.6 & 2.5 & $15 \%$ \\
\hline 1 & 156.39 & 0.7 & 0.18 & 0.12 & $150 \%$ & 2670.85 & 941.44 & 3.5 & $37 \%$ \\
\hline 2 & 161.16 & 0.7 & 0.18 & 0.12 & $150 \%$ & 2674.12 & 987.1 & 4.5 & $39 \%$ \\
\hline 3 & 155.87 & 0.7 & 0.18 & 0.12 & $150 \%$ & 2669.52 & 1025.1 & 4 & $41 \%$ \\
\hline 1 & 156.39 & 0.5 & 0.2778 & 0.2222 & $125 \%$ & 2672.02 & 644.76 & 3 & $26 \%$ \\
\hline 2 & 161.04 & 0.5 & 0.2778 & 0.2222 & $125 \%$ & 2672.78 & 638.16 & 2.75 & $25 \%$ \\
\hline 3 & 161.6 & 0.5 & 0.2778 & 0.2222 & $125 \%$ & 2676.99 & 698.42 & 5.5 & $28 \%$ \\
\hline 1 & 156.38 & 0.6 & 0.2222 & 0.1778 & $125 \%$ & 2669.82 & 1053.69 & 5 & $42 \%$ \\
\hline 2 & 161.3 & 0.6 & 0.2222 & 0.1778 & $125 \%$ & 2675.64 & 964.82 & 5 & $38 \%$ \\
\hline 3 & 156.15 & 0.6 & 0.2222 & 0.1778 & $125 \%$ & 2674.26 & 992.56 & 5 & $39 \%$ \\
\hline 1 & 161.77 & 0.7 & 0.1667 & 0.1333 & $125 \%$ & 2676.08 & 1271.44 & 4.75 & $51 \%$ \\
\hline 2 & 161.17 & 0.7 & 0.1667 & 0.1333 & $125 \%$ & 2676.8 & 1121.58 & 4 & $45 \%$ \\
\hline 3 & 156.46 & 0.7 & 0.1667 & 0.1333 & $125 \%$ & 2671.9 & 1117.08 & 4.25 & $44 \%$ \\
\hline 1 & 156.05 & 0.5 & 0.3182 & 0.1818 & $175 \%$ & 2670 & 846.26 & 6.25 & $34 \%$ \\
\hline 2 & 156.62 & 0.5 & 0.3182 & 0.1818 & $175 \%$ & 2670.76 & 769.69 & 3.25 & $31 \%$ \\
\hline 3 & 160.94 & 0.5 & 0.3182 & 0.1818 & $175 \%$ & 2673.06 & 608.88 & 3.5 & $24 \%$ \\
\hline 1 & 156.53 & 0.6 & 0.2545 & 0.1455 & $175 \%$ & 2673.94 & 1025.13 & 4.75 & $41 \%$ \\
\hline 2 & 161.12 & 0.6 & 0.2545 & 0.1455 & $175 \%$ & 2674.31 & 1069 & 4.5 & $43 \%$ \\
\hline 3 & 161.35 & 0.6 & 0.2545 & 0.1455 & $175 \%$ & 2672.9 & 1029.47 & 4.5 & $41 \%$ \\
\hline 1 & 156.23 & 0.7 & 0.1909 & 0.1091 & $175 \%$ & 2667.68 & 1205.22 & 4.25 & $48 \%$ \\
\hline 2 & 161.96 & 0.7 & 0.1909 & 0.1091 & $175 \%$ & 2675.16 & 1163.89 & 4.5 & $46 \%$ \\
\hline 3 & 155.98 & 0.7 & 0.1909 & 0.1091 & $175 \%$ & 2671.6 & 1151.42 & 4 & $46 \%$ \\
\hline 1 & 156.58 & 0.5 & 10Lime\% & 0.4 & 25\%Lime & 2649.35 & 260.41 & 1 & $10 \%$ \\
\hline 2 & 161.11 & 0.5 & 10Lime\% & 0.4 & 25\%Lime & 2654.5 & 232.16 & 1 & $9 \%$ \\
\hline 3 & 156.45 & 0.5 & 10Lime\% & 0.4 & 25\%Lime & 2650.32 & 246.03 & 1 & $10 \%$ \\
\hline 1 & 156.45 & 0.5 & 5.03POyShd & 0.3497 & 43\%POySh & 2643.02 & 213.45 & 1 & $9 \%$ \\
\hline 2 & 161.06 & 0.5 & 5.03POySh & 0.3497 & 43\%POySh & 2648.7 & 203.79 & 1 & $8 \%$ \\
\hline 3 & 155.76 & 0.5 & 5.03POySh & 0.3497 & 43\%POySh & 2645.93 & 177.38 & 1 & $7 \%$ \\
\hline 1 & 161.45 & 0.5 & 0.06POySh & 0.2994 & 67\%POySh & 2663.11 & 226.82 & 0.75 & $9 \%$ \\
\hline 2 & 161.68 & 0.5 & 0.06POySh & 0.2994 & 67\%POySh & 2658.61 & 310.39 & 1 & $12 \%$ \\
\hline 3 & 161.61 & 0.5 & 0.06POySh & 0.2994 & 67\%POySh & 2655.54 & 277.91 & 0.75 & $11 \%$ \\
\hline 1 & 156.65 & 0 & G3 & G3 & G3 & 2677.77 & 312.42 & 7 & $12 \%$ \\
\hline 2 & 155.88 & 0 & G3 & G3 & G3 & 2676.56 & 275.97 & 7 & $11 \%$ \\
\hline 3 & 161.6 & 0 & G3 & G3 & G3 & 2681.63 & 158.7 & 7 & $6 \%$ \\
\hline 1 & 161.83 & 0 & SoilTac & SoilTac & SoilTac & 2677.05 & 776.63 & 7 & $31 \%$ \\
\hline 2 & 162.01 & 0 & SoilTac & SoilTac & SoilTac & 2679.83 & 793.89 & 7.25 & $32 \%$ \\
\hline 3 & 156.92 & 0 & SoilTac & SoilTac & SoilTac & 2677.49 & 909.56 & 7 & $36 \%$ \\
\hline 1 & 156.47 & 0 & Klingstone & Klingstone & Klingstone & 2662.56 & 1219.83 & 6 & $49 \%$ \\
\hline 2 & 161.19 & 0 & Klingstone & Klingstone & Klingstone & 2668.89 & 1132.05 & 5.5 & $45 \%$ \\
\hline 3 & 161.4 & 0 & Klingstone & Klingstone & Klingstone & 2667.89 & 1207.79 & 6.5 & $48 \%$ \\
\hline 1 & 177.61 & 0.1 & SoilTac & SoilTac & SoilTac & 2678.39 & 1029.11 & 7 & $41 \%$ \\
\hline 2 & 173.38 & 0.1 & SoilTac & SoilTac & SoilTac & 2699.13 & 1077.8 & 7 & $43 \%$ \\
\hline 3 & 173.35 & 0.1 & SoilTac & SoilTac & SoilTac & 2670.7 & 970.15 & 7 & $39 \%$ \\
\hline 1 & 178.92 & 0.2 & SoilTac & SoilTac & SoilTac & 2686.41 & 1270.5 & 7 & $51 \%$ \\
\hline 2 & 178.33 & 0.2 & SoilTac & SoilTac & SoilTac & 2680.33 & 1227.6 & 7 & $49 \%$ \\
\hline 3 & 178.59 & 0.2 & SoilTac & SoilTac & SoilTac & 2680.85 & 1225.3 & 7 & $49 \%$ \\
\hline 1 & 178.74 & 0.3 & SoilTac & SoilTac & SoilTac & 2681.81 & 1319.16 & 7 & $53 \%$ \\
\hline 2 & 173.47 & 0.3 & SoilTac & SoilTac & SoilTac & 2677.12 & 1450.37 & 7 & $58 \%$ \\
\hline 3 & 175.89 & 0.3 & SoilTac & SoilTac & SoilTac & 2678.18 & 1334.72 & 7 & $53 \%$ \\
\hline 1 & 171.09 & 0.4 & SoilTac & SoilTac & SoilTac & 2672.33 & 1464.59 & 7 & $59 \%$ \\
\hline 2 & 171.28 & 0.4 & SoilTac & SoilTac & SoilTac & 2672.22 & 1456.78 & 7 & $58 \%$ \\
\hline 3 & 170.65 & 0.4 & SoilTac & SoilTac & SoilTac & 2663.87 & 1472.14 & 7 & $59 \%$ \\
\hline 1 & 171.29 & 0.5 & SoilTac & SoilTac & SoilTac & 2663.13 & 1477.72 & 7 & $59 \%$ \\
\hline 2 & 176.44 & 0.5 & SoilTac & SoilTac & SoilTac & 2671.43 & 1523.23 & 6.5 & $61 \%$ \\
\hline 3 & 175.9 & 0.5 & SoilTac & SoilTac & SoilTac & 2671.33 & 1352.46 & 7 & $54 \%$ \\
\hline 1 & 176.06 & 0.6 & SoilTac & SoilTac & SoilTac & 2667.21 & 1240.53 & 7 & $50 \%$ \\
\hline 2 & 175.88 & 0.6 & SoilTac & SoilTac & SoilTac & 2665.71 & 1366.52 & 7 & $55 \%$ \\
\hline 3 & 170.7 & 0.6 & SoilTac & SoilTac & SoilTac & 2655.1 & 1645.31 & 7 & $66 \%$ \\
\hline 1 & 176.42 & 0.7 & SoilTac & SoilTac & SoilTac & 2656.7 & 1697.02 & 6.75 & $68 \%$ \\
\hline 2 & 170.58 & 0.7 & SoilTac & SoilTac & SoilTac & 2651.23 & 1608.44 & 6.5 & $65 \%$ \\
\hline 3 & 176.8 & 0.7 & SoilTac & SoilTac & SoilTac & 2656.79 & 1326.19 & 6.75 & $53 \%$ \\
\hline 1 & 170.53 & 0.8 & SoilTac & SoilTac & SoilTac & 2639 & 1499.92 & 6 & $61 \%$ \\
\hline 2 & 171 & 0.8 & SoilTac & SoilTac & SoilTac & 2641.39 & 1570.85 & 6 & $64 \%$ \\
\hline 3 & 170.81 & 0.8 & SoilTac & SoilTac & SoilTac & 2639.21 & 1617.35 & 6.5 & $66 \%$ \\
\hline 1 & 171.58 & 0.9 & SoilTac & SoilTac & SoilTac & 2634.72 & 1389.71 & 5.75 & $56 \%$ \\
\hline 2 & 171.7 & 0.9 & SoilTac & SoilTac & SoilTac & 2631.63 & 1403.01 & 5.25 & $57 \%$ \\
\hline 3 & 170.86 & 0.9 & SoilTac & SoilTac & SoilTac & 2626.05 & 1396.61 & 6 & $57 \%$ \\
\hline
\end{tabular}




\subsection{LAB-SCALE TRAIL TEST}

\begin{tabular}{|c|c|c|c|c|c|c|c|c|}
\hline \multicolumn{9}{|c|}{ Trail Frame Results } \\
\hline Surface & Date & Avg. Firmness & Avg. Stability & Avg. Firmness + Stability & Treatment & Frame & Firmness Variabili & itystability Variability \\
\hline C1 Gravel & $8 / 20 / 2018$ & 0.297 & 1.649 & 1.946 & $\begin{array}{l}\text { Compacted with gas- } \\
\text { powered vibratory } \\
\text { compactor before testing. }\end{array}$ & 1 & $43 \%$ & $14 \%$ \\
\hline C1 Gravel & $8 / 20 / 2018$ & 0.274 & 1.616 & 1.890 & $\begin{array}{l}\text { Compacted with gas- } \\
\text { powered vibratory } \\
\text { compactor before testing, } \\
\text { pins moved to } 1 \text { from } 0 \\
\end{array}$ & 1 & $42 \%$ & $19 \%$ \\
\hline C1 Gravel & 8/29/2018 & 0.311 & 1.592 & 1.903 & $\begin{array}{l}\text { Compacted with gas- } \\
\text { powered vibratory } \\
\text { compactor before testing, } \\
\text { pins moved to } 2 \text { from } 1\end{array}$ & 1 & $51 \%$ & $9 \%$ \\
\hline C1 Gravel & 8/29/2018 & 0.255 & 1.527 & 1.782 & $\begin{array}{l}\text { Compacted with gas- } \\
\text { powered vibratory } \\
\text { compactor before testing, } \\
\text { pins moved to } 3 \text { from } 2\end{array}$ & 1 & $89 \%$ & $25 \%$ \\
\hline C1 Gravel & 8/29/2018 & 0.227 & 1.516 & 1.743 & $\begin{array}{c}\text { Compacted with gas- } \\
\text { powered vibratory } \\
\text { compactor before testing, } \\
\text { pins moved to } 4 \text { from } 3\end{array}$ & 1 & $39 \%$ & $29 \%$ \\
\hline C1 Gravel & 8/29/2018 & 0.230 & 1.468 & 1.698 & $\begin{array}{c}\text { Compacted with gas- } \\
\text { powered vibratory } \\
\text { compactor before testing, } \\
\text { pins moved to } 5 \text { from } 4\end{array}$ & 1 & $40 \%$ & $24 \%$ \\
\hline C1 Gravel & 8/29/2018 & 0.231 & 1.540 & 1.771 & $\begin{array}{l}\text { Compacted with gas- } \\
\text { powered vibratory } \\
\text { compactor before testing, } \\
\text { pins moved to } 6 \text { from } 5\end{array}$ & 1 & $5 \%$ & $28 \%$ \\
\hline C1-gravel & 9/12/2018 & 0.244 & 1.571 & 1.815 & None & 1 & $22 \%$ & $24 \%$ \\
\hline C1-gravel & 9/12/2018 & 0.241 & 1.491 & 1.733 & Pins moved to 1 from 0 & 1 & $22 \%$ & $10 \%$ \\
\hline C1-gravel & 9/12/2018 & 0.265 & 1.531 & 1.796 & Pins moved to 2 from 1 & 1 & $19 \%$ & $8 \%$ \\
\hline C1-gravel & 9/13/2018 & 0.223 & 1.456 & 1.680 & Pins moved to 3 from 2 & 1 & $54 \%$ & $14 \%$ \\
\hline C1-gravel & 9/13/2018 & 0.218 & 1.584 & 1.802 & Pins moved to 4 from 3 & 1 & $33 \%$ & $18 \%$ \\
\hline C1-gravel & 9/13/2018 & 0.277 & 1.611 & 1.888 & Pins moved to 5 from 4 & 1 & $45 \%$ & $16 \%$ \\
\hline C1-gravel & $10 / 23 / 2018$ & 0.201 & 0.328 & 0.529 & $\begin{array}{l}\text { A slurry of } 11.9 l b s \text { water, } \\
3.2 \mathrm{lbs} \text { volcanic ash, and } \\
4.8 \mathrm{lbs} \text { of portland cement } \\
\text { was topically applied and } \\
\text { left to cure for one week. }\end{array}$ & 1 & $22 \%$ & $29 \%$ \\
\hline C1-gravel & $10 / 25 / 2018$ & 0.217 & 0.363 & 0.580 & $\begin{array}{l}\text { A slurry of } 11.9 l b s \text { water, } \\
3.2 \mathrm{lbs} \text { volcanic ash, and } \\
4.8 \mathrm{lbs} \text { of portland cement } \\
\text { was topically applied and } \\
\text { left to cure for one week, } \\
\text { pins moved to } 1 \text { from } 0\end{array}$ & 1 & $32 \%$ & $42 \%$ \\
\hline C1-gravel & $10 / 25 / 2018$ & 0.155 & 0.426 & 0.581 & $\begin{array}{c}\text { A slurry of } 11.9 l \text { bs water, } \\
3.2 \mathrm{lbs} \text { volcanic ash, and } \\
4.81 \mathrm{bs} \text { of portland cement } \\
\text { was topically applied and } \\
\text { left to cure for one week, } \\
\text { scuffed by foot for } \sim 5 \\
\text { minutes }\end{array}$ & 1 & $42 \%$ & $73 \%$ \\
\hline C1-gravel & $10 / 30 / 2018$ & 0.193 & 0.554 & 0.746 & $\begin{array}{c}\text { A slurry of } 11.9 l \mathrm{bs} \text { water, } \\
3.2 \mathrm{lbs} \text { volcanic ash, and } \\
\text { 4.8lbs of portland cement } \\
\text { was topically applied and } \\
\text { left to cure for one week, } \\
\text { scuffed by foot for } \sim 5 \\
\text { minutes }\end{array}$ & 1 & $39 \%$ & $17 \%$ \\
\hline
\end{tabular}




\begin{tabular}{|c|c|c|c|c|c|c|c|c|}
\hline \multicolumn{9}{|c|}{ Trail Frame Results } \\
\hline Surface & Date & Avg. Firmness & \begin{tabular}{|l|} 
Avg. Stability \\
\end{tabular} & Avg. Firmness + Stability & Treatment & Frame & Firmness Vari & ity Variability \\
\hline C1-gravel (subsurface) & $10 / 31 / 2018$ & 0.186 & 0.665 & 0.851 & $\begin{array}{c}\text { A slurry of } 11.9 \text { lbs water, } \\
\text { 3.2lbs volcanic ash, and } \\
\text { 4.8lbs of portland cement } \\
\text { was topically applied and } \\
\text { left to cure for one week, } \\
\text { scuffed surface removed }\end{array}$ & 1 & $49 \%$ & $69 \%$ \\
\hline GeoTrail & \begin{tabular}{|l|}
$10 / 26 / 2018$ \\
\end{tabular} & 0.304 & 1.499 & 1.804 & None & 2 & $50 \%$ & $37 \%$ \\
\hline M5.0.1 & $11 / 2 / 2018$ & 0.278 & 1.477 & 1.755 & None & 2 & $48 \%$ & $110 \%$ \\
\hline Geotrail 60/150 & $11 / 9 / 2018$ & 0.285 & 0.926 & 1.210 & $\begin{array}{c}\text { A slurry of } 4.6 \mathrm{lbs} \text { water, } \\
1.2 \mathrm{lbs} \text { volcanic ash, and } \\
1.8 \mathrm{lbs} \text { of portland cement } \\
\text { was topically applied. }\end{array}$ & 2 & $12 \%$ & $40 \%$ \\
\hline GeoTrail mixed & $11 / 13 / 2018$ & 0.306 & 1.741 & 2.047 & None & 2 & $35 \%$ & $32 \%$ \\
\hline M5.0.1 & \begin{tabular}{|l|}
$11 / 26 / 2018$ \\
\end{tabular} & 0.249 & 0.962 & 1.211 & None & 1 & $64 \%$ & $53 \%$ \\
\hline C1 & $1 / 11 / 2019$ & 0.211 & 0.277 & 0.488 & \begin{tabular}{|c|} 
A slurry of $16.68 \mathrm{lbs}$ water, \\
6.67lbs volcanic ash, and \\
$4.45 \mathrm{lbs}$ of portland cement \\
was topically applied, then \\
allowed to cure two weeks \\
indoors and then two weeks \\
in natural freezing \\
conditions
\end{tabular} & 1 & $55 \%$ & $62 \%$ \\
\hline C1 & $1 / 14 / 2019$ & 0.137 & 0.457 & 0.594 & $\begin{array}{c}\text { A slurry of } 16.68 \mathrm{lbs} \text { water, } \\
6.67 \mathrm{lbs} \text { volcanic ash, and } \\
4.45 \mathrm{lbs} \text { of portland cement } \\
\text { was topically applied, then } \\
\text { allowed to cure two weeks } \\
\text { indoors and then two weeks } \\
\text { in natural freezing } \\
\text { conditions, scuffed by foot } \\
\text { for } \sim 5 \text { minutes }\end{array}$ & 1 & $87 \%$ & $86 \%$ \\
\hline C1 & $1 / 14 / 2019$ & 0.169 & 0.610 & 0.779 & $\begin{array}{c}\text { A slurry of } 18.53 \mathrm{lbs} \text { water, } \\
7.41 \mathrm{lbs} \text { volcanic ash, and } \\
\text { 4.94lbs of portland cement } \\
\text { was topically applied, then } \\
\text { allowed to cure four weeks } \\
\text { in natural freezing } \\
\text { conditions }\end{array}$ & 1 & $85 \%$ & $60 \%$ \\
\hline $\mathrm{C} 1$ & $1 / 14 / 2019$ & 0.166 & 0.951 & 1.117 & \begin{tabular}{|c|} 
A slurry of $18.53 l \mathrm{bs}$ water, \\
$7.41 \mathrm{lbs}$ volcanic ash, and \\
$4.94 \mathrm{lbs}$ of portland cement \\
was topically applied, then \\
allowed to cure four weeks \\
in natural freezing \\
conditions, scuffed by foot \\
for $\sim 5$ minutes
\end{tabular} & 1 & $37 \%$ & $54 \%$ \\
\hline C1 & $2 / 22 / 2019$ & 0.329 & 1.478 & 1.806 & None & 2 & $58 \%$ & $14 \%$ \\
\hline $\mathrm{C} 1$ & 3/1/2019 & 0.199 & 0.428 & 0.627 & $\begin{array}{c}\text { A slurry of } 16 \text { lbs water, } \\
\text { 6.4lbs volcanic ash, and } \\
\text { 4.27lbs of portland cement } \\
\text { was topically applied, and } \\
\text { cured for one week } \\
\end{array}$ & 2 & $63 \%$ & $48 \%$ \\
\hline C1 & $3 / 1 / 2019$ & 0.206 & 1.134 & 1.339 & \begin{tabular}{|} 
A slurry of $16 \mathrm{lbs}$ water, \\
6.4lbs volcanic ash, and \\
4.27lbs of portland cement \\
was topically applied, and \\
cured for one week, scuffed \\
by foot for $\sim 5$ minutes
\end{tabular} & 2 & $47 \%$ & $19 \%$ \\
\hline $\mathrm{C} 1$ & $3 / 14 / 2019$ & 0.193 & 1.130 & 1.323 & $\begin{array}{c}\text { A slurry of } 16 \mathrm{lbs} \text { water, } \\
6.4 \text { lbs volcanic ash, and } \\
4.27 \mathrm{lbs} \text { of portland cement } \\
\text { was topically applied, and } \\
\text { cured for one week, scuffed } \\
\text { by foot for } \sim 5 \text { minutes, } \\
\text { device rotated } 90 \text { degrees }\end{array}$ & 2 & $19 \%$ & $23 \%$ \\
\hline C1 & \begin{tabular}{|l|}
$3 / 15 / 2019$ \\
\end{tabular} & 0.267 & 1.488 & 1.754 & None & 1 & $19 \%$ & $13 \%$ \\
\hline
\end{tabular}




\begin{tabular}{|c|c|c|c|c|c|c|c|c|}
\hline \multicolumn{9}{|c|}{ Trail Frame Results } \\
\hline Surface & Date & Avg. Firmness & Avg. Stability & Avg. Firmness + Stability & Treatment & Frame & Firmness Vari & ity Variability \\
\hline $\mathrm{C} 1$ & $3 / 22 / 2019$ & 0.211 & 1.137 & 1.348 & \begin{tabular}{|c|} 
A slurry of 7.5lbs water, \\
3lbs volcanic ash, and 2lbs \\
of portland cement was \\
topically applied, and \\
cured for one week \\
\end{tabular} & 1 & $18 \%$ & $24 \%$ \\
\hline $\mathrm{C} 1$ & 3/22/2019 & 0.289 & 1.399 & 1.688 & $\begin{array}{c}\text { A slurry of 7.5lbs water, } \\
\text { 3lbs volcanic ash, and 2lbs } \\
\text { of portland cement was } \\
\text { topically applied, and } \\
\text { cured for one week, scuffed } \\
\text { by foot for } \sim 5 \text { minutes }\end{array}$ & 1 & $28 \%$ & $13 \%$ \\
\hline $\mathrm{C} 1$ & $3 / 25 / 2019$ & 0.201 & 1.261 & 1.462 & $\begin{array}{c}\text { A slurry of 7.5lbs water, } \\
\text { 3lbs volcanic ash, and 2lbs } \\
\text { of portland cement was } \\
\text { topically applied, and } \\
\text { cured for one week, scuffed } \\
\text { by foot for } \sim 10 \text { minutes }\end{array}$ & 2 & $49 \%$ & $12 \%$ \\
\hline $\mathrm{C} 1$ & $5 / 8 / 2019$ & 0.341 & 1.521 & 1.862 & None & 1 & $95 \%$ & $26 \%$ \\
\hline $\mathrm{C} 1$ & $5 / 17 / 2019$ & 0.291 & 0.816 & 1.107 & \begin{tabular}{|c|} 
A slurry of 7.5lbs water, \\
3lbs volcanic ash, and 2lbs \\
of portland cement was \\
topically applied, and \\
cured for one week
\end{tabular} & 1 & $20 \%$ & $19 \%$ \\
\hline $\mathrm{C} 1$ & $5 / 17 / 2019$ & 0.266 & 1.231 & 1.497 & $\begin{array}{c}\text { A slurry of 7.5lbs water, } \\
\text { 3lbs volcanic ash, and 2lbs } \\
\text { of portland cement was } \\
\text { topically applied, and } \\
\text { cured for one week, scuffed } \\
\text { by foot for } \sim 5 \text { minutes }\end{array}$ & 1 & $32 \%$ & $98 \%$ \\
\hline C1 & $5 / 8 / 2019$ & 0.272 & 1.448 & 1.719 & None & 2 & $60 \%$ & $63 \%$ \\
\hline $\mathrm{C} 1$ & $5 / 17 / 2019$ & 0.268 & 0.897 & 1.165 & \begin{tabular}{|c|} 
A slurry of 7.5lbs water, \\
3lbs volcanic ash, and 2lbs \\
of portland cement was \\
topically applied, and \\
cured for one week
\end{tabular} & 2 & $45 \%$ & $32 \%$ \\
\hline C1 & $5 / 17 / 2019$ & 0.263 & 1.255 & 1.518 & $\begin{array}{c}\text { A slurry of 7.5lbs water, } \\
\text { 3lbs volcanic ash, and 2lbs } \\
\text { of portland cement was } \\
\text { topically applied, and } \\
\text { cured for one week, scuffed } \\
\text { by foot for } \sim 5 \text { minutes }\end{array}$ & 2 & $25 \%$ & $14 \%$ \\
\hline
\end{tabular}




\subsection{FIELD-SCALE DATA}




\begin{tabular}{|c|c|c|c|c|c|c|c|}
\hline \multicolumn{8}{|c|}{ GeoTrail Penetrometer Results } \\
\hline Location & Date & \begin{tabular}{|c|} 
Avg. \\
Firmness \\
\end{tabular} & Avg. Stability & $\begin{array}{c}\text { Avg. Firmness + } \\
\text { Stability }\end{array}$ & Treatment & $\begin{array}{c}\text { Firmness } \\
\text { Variability }\end{array}$ & \begin{tabular}{|c|} 
Stability \\
Variability \\
\end{tabular} \\
\hline GeoTrail & $10 / 12 / 2018$ & 0.140 & 0.430 & 0.570 & None & $44 \%$ & $41 \%$ \\
\hline GeoTrail & \begin{tabular}{|l|}
$5 / 22 / 2019$ \\
\end{tabular} & 0.159 & 0.485 & 0.644 & None & $54 \%$ & $56 \%$ \\
\hline $\begin{array}{c}\text { GeoTrail } \\
70 / 175\end{array}$ & $5 / 29 / 2019$ & 0.218 & 0.609 & 0.827 & $\begin{array}{c}\text { A slurry of } 9.8 \mathrm{lbs} \text { water, } \\
2.666 \mathrm{lbs} \text { volcanic ash, } \\
\text { and } 1.53 \mathrm{lbs} \text { of portland } \\
\text { cement was topically } \\
\text { applied, and cured for } \\
\text { one week }\end{array}$ & $21 \%$ & $25 \%$ \\
\hline $\begin{array}{c}\text { GeoTrail } \\
70 / 175\end{array}$ & $6 / 5 / 2019$ & 0.176 & 0.546 & 0.721 & $\begin{array}{c}\text { A slurry of } 9.8 \mathrm{lbs} \text { water, } \\
2.666 \mathrm{lbs} \text { volcanic ash, } \\
\text { and } 1.53 \mathrm{lbs} \text { of portland } \\
\text { cement was topically } \\
\text { applied, and cured for } \\
\text { one week }\end{array}$ & $29 \%$ & $29 \%$ \\
\hline $\begin{array}{c}\text { Geotrail } \\
\text { Lot } 1\end{array}$ & $7 / 2 / 2019$ & 0.162 & 0.646 & 0.808 & None & $17 \%$ & $38 \%$ \\
\hline $\begin{array}{c}\text { Geotrail } \\
\text { Lot } 2\end{array}$ & $7 / 2 / 2019$ & 0.151 & 0.567 & 0.718 & None & $25 \%$ & $15 \%$ \\
\hline $\begin{array}{c}\text { Geotrail } \\
\text { Lot } 3 \\
\end{array}$ & $7 / 2 / 2019$ & 0.161 & 0.591 & 0.752 & None & $23 \%$ & $25 \%$ \\
\hline $\begin{array}{c}\text { Geotrail } \\
\text { Lot } 1\end{array}$ & $7 / 9 / 2019$ & 0.160 & 0.745 & 0.905 & $\begin{array}{c}\text { A slurry of } 9.8 \mathrm{lbs} \text { water, } \\
2.66 \mathrm{lbs} \text { volcanic ash, and } \\
1.53 \mathrm{lbs} \text { of portland } \\
\text { cement was topically } \\
\text { applied, and cured for } \\
\text { one week } \\
\end{array}$ & $16 \%$ & $15 \%$ \\
\hline $\begin{array}{c}\text { Geotrail } \\
\text { Lot } 2\end{array}$ & 7/9/2019 & 0.187 & 0.684 & 0.871 & \begin{tabular}{|c|} 
A slurry of $7 \mathrm{lbs}$ water, \\
$4.45 \mathrm{lbs}$ volcanic ash, and \\
$2.55 \mathrm{lbs}$ of portland \\
cement was topically \\
applied, and cured for \\
one week \\
\end{tabular} & $16 \%$ & $29 \%$ \\
\hline $\begin{array}{c}\text { Geotrail } \\
\text { Lot } 3\end{array}$ & 7/9/2019 & 0.179 & 0.718 & 0.897 & $\begin{array}{c}\text { A slurry of 7lbs water, } \\
4.2 \mathrm{lbs} \text { volcanic ash, and } \\
2.8 \mathrm{lbs} \text { of portland cement } \\
\text { was topically applied, and } \\
\text { cured for one week }\end{array}$ & $46 \%$ & $24 \%$ \\
\hline $\begin{array}{c}\text { Geotrail } \\
\text { Lot } 1\end{array}$ & $8 / 13 / 2019$ & 0.160 & 0.407 & 0.567 & $\begin{array}{l}\text { A slurry of } 9.8 \mathrm{lbs} \text { water, } \\
2.66 \mathrm{lbs} \text { volcanic ash, and } \\
1.53 \mathrm{lbs} \text { of portland } \\
\text { cement was topically } \\
\text { applied for the second } \\
\text { time after testing. }\end{array}$ & $31 \%$ & $24 \%$ \\
\hline
\end{tabular}




\begin{tabular}{|c|c|c|c|c|c|c|c|}
\hline \multicolumn{8}{|c|}{ GeoTrail Penetrometer Results } \\
\hline Location & Date & \begin{tabular}{|c} 
Avg. \\
Firmness
\end{tabular} & Avg. Stability & $\begin{array}{l}\text { Avg. Firmness + } \\
\text { Stability }\end{array}$ & Treatment & $\begin{array}{c}\text { Firmness } \\
\text { Variability }\end{array}$ & \begin{tabular}{|c|} 
Stability \\
Variability
\end{tabular} \\
\hline $\begin{array}{c}\text { Geotrail } \\
\text { Lot } 2\end{array}$ & $8 / 13 / 2019$ & 0.185 & 0.423 & 0.608 & $\begin{array}{l}\text { A slurry of 7lbs water, } \\
4.45 \mathrm{lbs} \text { volcanic ash, and } \\
2.55 \mathrm{lbs} \text { of portland } \\
\text { cement was topically } \\
\text { applied for the second } \\
\text { time after testing. }\end{array}$ & $31 \%$ & $60 \%$ \\
\hline $\begin{array}{c}\text { Geotrail } \\
\text { Lot } 3\end{array}$ & $8 / 13 / 2019$ & 0.214 & 0.293 & 0.507 & $\begin{array}{c}\text { A slurry of 7lbs water, } \\
\text { 4.2lbs volcanic ash, and } \\
2.8 \mathrm{lbs} \text { of portland cement } \\
\text { was topically applied for } \\
\text { the second time after } \\
\text { testing. }\end{array}$ & $20 \%$ & $77 \%$ \\
\hline \begin{tabular}{|c|} 
Geotrail \\
Lot 4 \\
\end{tabular} & $8 / 14 / 2019$ & 0.160 & 0.518 & 0.678 & $\begin{array}{l}\text { Surficially treated with } \\
\text { Klingstone Amber. }\end{array}$ & $51 \%$ & $21 \%$ \\
\hline $\begin{array}{l}\text { Geotrail } \\
\text { Lot } 5\end{array}$ & $8 / 14 / 2019$ & 0.162 & 0.542 & 0.704 & $\begin{array}{c}\text { Surficially treated with } \sim 1 \\
\text { gallon of } \mathrm{G} 3 \text { stabilizer }\end{array}$ & $29 \%$ & $18 \%$ \\
\hline \begin{tabular}{|c|} 
Geotrail \\
Lot 6 \\
\end{tabular} & $8 / 14 / 2019$ & 0.180 & 0.555 & 0.735 & & $42 \%$ & $20 \%$ \\
\hline $\begin{array}{c}\text { Geotrail } \\
\text { Lot } 1\end{array}$ & $8 / 20 / 2019$ & 0.175 & 0.503 & 0.678 & \begin{tabular}{|c|} 
A slurry of $9.8 \mathrm{lbs}$ water, \\
$2.66 \mathrm{lbs}$ volcanic ash, and \\
$1.53 \mathrm{lbs}$ of portland \\
cement was topically \\
applied, and cured for \\
one week
\end{tabular} & $28 \%$ & $66 \%$ \\
\hline $\begin{array}{c}\text { Geotrail } \\
\text { Lot } 2\end{array}$ & $8 / 20 / 2019$ & 0.178 & 0.434 & 0.612 & $\begin{array}{c}\text { A slurry of 7lbs water, } \\
4.45 \mathrm{lbs} \text { volcanic ash, and } \\
2.55 \mathrm{lbs} \text { of portland } \\
\text { cement was topically } \\
\text { applied, and cured for } \\
\text { one week }\end{array}$ & $20 \%$ & $82 \%$ \\
\hline $\begin{array}{c}\text { Geotrail } \\
\text { Lot } 3\end{array}$ & $8 / 20 / 2019$ & 0.195 & 0.335 & 0.530 & $\begin{array}{c}\text { A slurry of } 7 \mathrm{lbs} \text { water, } \\
4.2 \mathrm{lbs} \text { volcanic ash, and } \\
2.8 \mathrm{lbs} \text { of portland cement } \\
\text { was topically applied, and } \\
\text { cured for one week }\end{array}$ & $29 \%$ & $96 \%$ \\
\hline \begin{tabular}{|c|} 
Geotrail \\
Lot 4 \\
\end{tabular} & $8 / 21 / 2019$ & 0.196 & 0.263 & 0.459 & $\begin{array}{c}\text { Surficially treated with } \\
\text { Klingstone Amber. }\end{array}$ & $48 \%$ & $49 \%$ \\
\hline $\begin{array}{c}\text { Geotrail } \\
\text { Lot } 5\end{array}$ & $8 / 21 / 2019$ & 0.160 & 0.204 & 0.364 & $\begin{array}{l}\text { Surficially treated with } \sim 1 \\
\text { gallon of } \mathrm{G} 3 \text { stabilizer }\end{array}$ & $53 \%$ & $34 \%$ \\
\hline \begin{tabular}{|c|} 
Geotrail \\
Lot 7 \\
\end{tabular} & $8 / 22 / 2019$ & 0.154 & 0.522 & 0.676 & & $28 \%$ & $28 \%$ \\
\hline \begin{tabular}{|c|} 
Geotrail \\
Lot 8 \\
\end{tabular} & $8 / 22 / 2019$ & 0.202 & 0.705 & 0.907 & & $102 \%$ & $42 \%$ \\
\hline \begin{tabular}{|c|} 
Geotrail \\
Lot 9 \\
\end{tabular} & $8 / 22 / 2019$ & 0.174 & 0.532 & 0.706 & & $17 \%$ & $74 \%$ \\
\hline \begin{tabular}{|c|} 
Geotrail \\
Lot 10 \\
\end{tabular} & $8 / 22 / 2019$ & 0.156 & 0.528 & 0.684 & & $27 \%$ & $27 \%$ \\
\hline \begin{tabular}{|c|} 
Geotrail \\
Lot 11 \\
\end{tabular} & $8 / 22 / 2019$ & 0.172 & 0.436 & 0.608 & & $26 \%$ & $36 \%$ \\
\hline
\end{tabular}




\begin{tabular}{|c|c|c|c|c|c|c|c|}
\hline \multicolumn{8}{|c|}{ GeoTrail Penetrometer Results } \\
\hline Location & Date & \begin{tabular}{|c|} 
Avg. \\
Firmness
\end{tabular} & Avg. Stability & $\begin{array}{c}\text { Avg. Firmness + } \\
\text { Stability } \\
\end{array}$ & Treatment & $\begin{array}{c}\text { Firmness } \\
\text { Variability }\end{array}$ & \begin{tabular}{|c|} 
Stability \\
Variability
\end{tabular} \\
\hline $\begin{array}{c}\text { Geotrail } \\
\text { Lot } 12\end{array}$ & $8 / 22 / 2019$ & 0.162 & 0.517 & 0.679 & & $30 \%$ & $74 \%$ \\
\hline $\begin{array}{c}\text { Geotrail } \\
\text { Lot } 1\end{array}$ & $8 / 27 / 2019$ & 0.156 & 0.363 & 0.519 & $\begin{array}{c}\text { A slurry of } 9.8 \mathrm{lbs} \text { water, } \\
2.66 \mathrm{lbs} \text { volcanic ash, and } \\
1.53 \mathrm{lbs} \text { of portland } \\
\text { cement was topically } \\
\text { applied, and cured for } \\
\text { one week }\end{array}$ & $21 \%$ & $47 \%$ \\
\hline $\begin{array}{c}\text { Geotrail } \\
\text { Lot } 2\end{array}$ & $8 / 27 / 2019$ & 0.183 & 0.489 & 0.672 & $\begin{array}{c}\text { A slurry of 7lbs water, } \\
4.45 \mathrm{lbs} \text { volcanic ash, and } \\
2.55 \mathrm{lbs} \text { of portland } \\
\text { cement was topically } \\
\text { applied, and cured for } \\
\text { one week }\end{array}$ & $32 \%$ & $99 \%$ \\
\hline $\begin{array}{c}\text { Geotrail } \\
\text { Lot } 3\end{array}$ & $8 / 27 / 2019$ & 0.195 & 0.257 & 0.452 & $\begin{array}{c}\text { A slurry of } 7 \mathrm{lbs} \text { water, } \\
4.2 \mathrm{lbs} \text { volcanic ash, and } \\
2.8 \mathrm{lbs} \text { of portland cement } \\
\text { was topically applied, and } \\
\text { cured for one week }\end{array}$ & $12 \%$ & $178 \%$ \\
\hline $\begin{array}{c}\text { Geotrail } \\
\text { Lot } 4 \\
\end{array}$ & $8 / 28 / 2019$ & 0.179 & 0.197 & 0.376 & $\begin{array}{l}\text { Surficially treated with } \\
\text { Klingstone Amber. }\end{array}$ & $30 \%$ & $26 \%$ \\
\hline $\begin{array}{l}\text { Geotrail } \\
\text { Lot } 5\end{array}$ & $8 / 28 / 2019$ & 0.188 & 0.214 & 0.402 & $\begin{array}{c}\text { Surficially treated with } \sim 1 \\
\text { gallon of } \mathrm{G} 3 \text { stabilizer }\end{array}$ & $38 \%$ & $32 \%$ \\
\hline $\begin{array}{c}\text { Geotrail } \\
\text { Lot } 7\end{array}$ & $8 / 29 / 2018$ & 0.169 & 0.641 & 0.810 & $\begin{array}{l}\text { A slurry of } 3.5 \mathrm{lbs} \text { water, } \\
1.94 \mathrm{lbs} \text { volcanic ash, and } \\
1.56 \mathrm{lbs} \text { of portland } \\
\text { cement was topically } \\
\text { applied for the second } \\
\text { time after testing. }\end{array}$ & $47 \%$ & $34 \%$ \\
\hline $\begin{array}{c}\text { Geotrail } \\
\text { Lot } 1\end{array}$ & $9 / 3 / 2019$ & 0.173 & 0.433 & 0.606 & $\begin{array}{c}\text { A slurry of } 9.8 \mathrm{lbs} \text { water, } \\
2.66 \mathrm{lbs} \text { volcanic ash, and } \\
1.53 \mathrm{lbs} \text { of portland } \\
\text { cement was topically } \\
\text { applied, and cured for } \\
\text { one week }\end{array}$ & $59 \%$ & $37 \%$ \\
\hline $\begin{array}{c}\text { Geotrail } \\
\text { Lot } 2\end{array}$ & $9 / 3 / 2019$ & 0.196 & 0.533 & 0.729 & $\begin{array}{c}\text { A slurry of 7lbs water, } \\
4.45 \mathrm{lbs} \text { volcanic ash, and } \\
2.55 \mathrm{lbs} \text { of portland } \\
\text { cement was topically } \\
\text { applied, and cured for } \\
\text { one week }\end{array}$ & $40 \%$ & $68 \%$ \\
\hline $\begin{array}{c}\text { Geotrail } \\
\text { Lot } 3\end{array}$ & $9 / 3 / 2019$ & 0.171 & 0.246 & 0.417 & $\begin{array}{c}\text { A slurry of } 7 \mathrm{lbs} \text { water, } \\
4.2 \mathrm{lbs} \text { volcanic ash, and } \\
2.8 \mathrm{lbs} \text { of portland cement } \\
\text { was topically applied, and } \\
\text { cured for one week }\end{array}$ & $7 \%$ & $44 \%$ \\
\hline
\end{tabular}




\begin{tabular}{|c|c|c|c|c|c|c|c|}
\hline \multicolumn{8}{|c|}{ GeoTrail Penetrometer Results } \\
\hline Location & Date & $\begin{array}{c}\text { Avg. } \\
\text { Firmness }\end{array}$ & Avg. Stability & $\begin{array}{c}\text { Avg. Firmness + } \\
\text { Stability }\end{array}$ & Treatment & $\begin{array}{c}\text { Firmness } \\
\text { Variability }\end{array}$ & \begin{tabular}{|c|} 
Stability \\
Variability \\
\end{tabular} \\
\hline $\begin{array}{c}\text { Geotrail } \\
\text { Lot } 8\end{array}$ & $9 / 3 / 2019$ & 0.203 & 0.711 & 0.914 & \begin{tabular}{|c|} 
A slurry of $4.2 \mathrm{lbs}$ water, \\
$1.56 \mathrm{lbs}$ volcanic ash, and \\
$1.24 \mathrm{lbs}$ of portland \\
cement was topically \\
applied, and cured for \\
one week \\
\end{tabular} & $43 \%$ & $90 \%$ \\
\hline $\begin{array}{c}\text { Geotrail } \\
\text { Lot } 9\end{array}$ & 9/3/2019 & 0.186 & 0.581 & 0.767 & \begin{tabular}{|c|} 
A slurry of $7 \mathrm{lbs}$ water, \\
$1.68 \mathrm{lbs}$ volcanic ash, and \\
$1.12 \mathrm{lbs}$ of portland \\
cement was topically \\
applied, and cured for \\
one week
\end{tabular} & $45 \%$ & $49 \%$ \\
\hline $\begin{array}{c}\text { Geotrail } \\
\text { Lot } 10\end{array}$ & 9/3/2019 & 0.200 & 0.595 & 0.795 & \begin{tabular}{|c|} 
A slurry of $4.2 \mathrm{lbs}$ water, \\
$1.78 \mathrm{lbs}$ volcanic ash, and \\
$1.02 \mathrm{lbs}$ of portland \\
cement was topically \\
applied, and cured for \\
one week \\
\end{tabular} & $28 \%$ & $68 \%$ \\
\hline $\begin{array}{c}\text { Geotrail } \\
\text { Lot } 4 \\
\end{array}$ & $9 / 4 / 2019$ & 0.183 & 0.273 & 0.456 & $\begin{array}{l}\text { Surficially treated with } \\
\text { Klingstone Amber. }\end{array}$ & $58 \%$ & $85 \%$ \\
\hline $\begin{array}{c}\text { Geotrail } \\
\text { Lot } 5\end{array}$ & 9/4/2019 & 0.199 & 0.235 & 0.434 & $\begin{array}{c}\text { Surficially treated with } \sim 1 \\
\text { gallon of G3 stabilizer }\end{array}$ & $33 \%$ & $58 \%$ \\
\hline $\begin{array}{c}\text { Geotrail } \\
\text { Lot } 7\end{array}$ & 9/5/2019 & 0.176 & 0.520 & 0.696 & $\begin{array}{l}\text { A slurry of } 3.5 \mathrm{lbs} \text { water, } \\
1.94 \mathrm{lbs} \text { volcanic ash, and } \\
1.56 \mathrm{lbs} \text { of portland } \\
\text { cement was topically } \\
\text { applied for the second } \\
\text { time after testing. }\end{array}$ & $16 \%$ & $24 \%$ \\
\hline $\begin{array}{c}\text { Geotrail } \\
\text { Lot } 1\end{array}$ & $9 / 10 / 2019$ & 0.186 & 0.401 & 0.587 & \begin{tabular}{|c|} 
A slurry of $9.8 \mathrm{lbs}$ water, \\
$2.66 \mathrm{lbs}$ volcanic ash, and \\
$1.53 \mathrm{lbs}$ of portland \\
cement was topically \\
applied, and cured for \\
one week \\
\end{tabular} & $9 \%$ & $62 \%$ \\
\hline $\begin{array}{c}\text { Geotrail } \\
\text { Lot } 2\end{array}$ & $9 / 10 / 2019$ & 0.172 & 0.204 & 0.376 & \begin{tabular}{|c|} 
A slurry of 7lbs water, \\
$4.45 \mathrm{lbs}$ volcanic ash, and \\
$2.55 \mathrm{lbs}$ of portland \\
cement was topically \\
applied, and cured for \\
one week \\
\end{tabular} & $20 \%$ & $145 \%$ \\
\hline $\begin{array}{c}\text { Geotrail } \\
\text { Lot } 3\end{array}$ & $9 / 10 / 2019$ & 0.158 & 0.202 & 0.360 & $\begin{array}{c}\text { A slurry of } 7 \mathrm{lbs} \text { water, } \\
4.2 \mathrm{lbs} \text { volcanic ash, and } \\
2.8 \mathrm{lbs} \text { of portland cement } \\
\text { was topically applied, and } \\
\text { cured for one week }\end{array}$ & $26 \%$ & $34 \%$ \\
\hline
\end{tabular}




\begin{tabular}{|c|c|c|c|c|c|c|c|}
\hline \multicolumn{8}{|c|}{ GeoTrail Penetrometer Results } \\
\hline Location & Date & $\begin{array}{c}\text { Avg. } \\
\text { Firmness }\end{array}$ & Avg. Stability & $\begin{array}{l}\text { Avg. Firmness + } \\
\text { Stability }\end{array}$ & Treatment & $\begin{array}{c}\text { Firmness } \\
\text { Variability }\end{array}$ & \begin{tabular}{|c|} 
Stability \\
Variability \\
\end{tabular} \\
\hline $\begin{array}{c}\text { Geotrail } \\
\text { Lot } 8\end{array}$ & 9/10/2019 & 0.182 & 0.703 & 0.885 & $\begin{array}{c}\text { A slurry of } 4.2 \mathrm{lbs} \text { water, } \\
1.56 \mathrm{lbs} \text { volcanic ash, and } \\
1.24 \mathrm{lbs} \text { of portland } \\
\text { cement was topically } \\
\text { applied, and cured for } \\
\text { one week }\end{array}$ & $35 \%$ & $71 \%$ \\
\hline $\begin{array}{c}\text { Geotrail } \\
\text { Lot } 9\end{array}$ & 9/10/2019 & 0.175 & 0.444 & 0.619 & $\begin{array}{c}\text { A slurry of 7lbs water, } \\
1.68 \mathrm{lbs} \text { volcanic ash, and } \\
1.12 \mathrm{lbs} \text { of portland } \\
\text { cement was topically } \\
\text { applied, and cured for } \\
\text { one week }\end{array}$ & $21 \%$ & $116 \%$ \\
\hline $\begin{array}{c}\text { Geotrail } \\
\text { Lot } 10\end{array}$ & 9/10/2019 & 0.199 & 0.659 & 0.858 & \begin{tabular}{|c|} 
A slurry of $4.2 \mathrm{lbs}$ water, \\
$1.78 \mathrm{lbs}$ volcanic ash, and \\
$1.02 \mathrm{lbs}$ of portland \\
cement was topically \\
applied, and cured for \\
one week
\end{tabular} & $28 \%$ & $46 \%$ \\
\hline $\begin{array}{c}\text { Geotrail } \\
\text { Lot } 11\end{array}$ & 9/10/2019 & 0.174 & 0.412 & 0.586 & $\begin{array}{c}\text { A slurry of } 4.9 \mathrm{lbs} \text { water, } \\
1.17 \mathrm{lbs} \text { volcanic ash, and } \\
0.93 \mathrm{lbs} \text { of portland } \\
\text { cement was topically } \\
\text { applied, and cured for } \\
\text { one week }\end{array}$ & $26 \%$ & $105 \%$ \\
\hline $\begin{array}{c}\text { Geotrail } \\
\text { Lot } 12\end{array}$ & $9 / 10 / 2019$ & 0.193 & 0.503 & 0.696 & \begin{tabular}{|c|} 
A slurry of $4.9 \mathrm{lbs}$ water, \\
$1.26 \mathrm{lbs}$ volcanic ash, and \\
$0.84 \mathrm{lbs}$ of portland \\
cement was topically \\
applied, and cured for \\
one week
\end{tabular} & $34 \%$ & $93 \%$ \\
\hline $\begin{array}{c}\text { Geotrail } \\
\text { Lot } 4 \\
\end{array}$ & 9/11/2019 & 0.167 & 0.193 & 0.360 & $\begin{array}{l}\text { Surficially treated with } \\
\text { Klingstone Amber. }\end{array}$ & $21 \%$ & $92 \%$ \\
\hline $\begin{array}{c}\text { Geotrail } \\
\text { Lot } 5\end{array}$ & $9 / 11 / 2019$ & 0.168 & 0.223 & 0.391 & $\begin{array}{c}\text { Surficially treated with } \sim 1 \\
\text { gallon of } \mathrm{G} 3 \text { stabilizer }\end{array}$ & $47 \%$ & $59 \%$ \\
\hline $\begin{array}{c}\text { Geotrail } \\
\text { Lot } 6\end{array}$ & $9 / 12 / 2019$ & 0.163 & 0.219 & 0.382 & $\begin{array}{c}\text { Surficially treated with } \sim 1 \\
\text { gallon of SoilTac Liquid } \\
\text { Topical stabilizer diluted } \\
\text { to a } 30 \% \text { concentration } \\
\text { with water. }\end{array}$ & $10 \%$ & $21 \%$ \\
\hline $\begin{array}{c}\text { Geotrail } \\
\text { Lot } 7\end{array}$ & $9 / 12 / 2019$ & 0.172 & 0.682 & 0.854 & $\begin{array}{l}\text { A slurry of } 3.5 \mathrm{lbs} \text { water, } \\
1.94 \mathrm{lbs} \text { volcanic ash, and } \\
1.56 \mathrm{lbs} \text { of portland } \\
\text { cement was topically } \\
\text { applied for the second } \\
\text { time after testing. }\end{array}$ & $18 \%$ & $46 \%$ \\
\hline
\end{tabular}




\begin{tabular}{|c|c|c|c|c|c|c|c|}
\hline \multicolumn{8}{|c|}{ GeoTrail Penetrometer Results } \\
\hline Location & Date & $\begin{array}{c}\text { Avg. } \\
\text { Firmness }\end{array}$ & Avg. Stability & $\begin{array}{c}\text { Avg. Firmness + } \\
\text { Stability }\end{array}$ & Treatment & $\begin{array}{c}\text { Firmness } \\
\text { Variability }\end{array}$ & \begin{tabular}{|c|} 
Stability \\
Variability \\
\end{tabular} \\
\hline $\begin{array}{c}\text { Geotrail } \\
\text { Lot } 1\end{array}$ & 9/17/2019 & 0.183 & 0.509 & 0.692 & \begin{tabular}{|c|} 
A slurry of $9.8 \mathrm{lbs}$ water, \\
$2.66 \mathrm{lbs}$ volcanic ash, and \\
$1.53 \mathrm{lbs}$ of portland \\
cement was topically \\
applied, and cured for \\
one week \\
\end{tabular} & $9 \%$ & $62 \%$ \\
\hline $\begin{array}{c}\text { Geotrail } \\
\text { Lot } 2\end{array}$ & $9 / 17 / 2019$ & 0.179 & 0.304 & 0.483 & \begin{tabular}{|c|} 
A slurry of $7 \mathrm{lbs}$ water, \\
$4.45 \mathrm{lbs}$ volcanic ash, and \\
$2.55 \mathrm{lbs}$ of portland \\
cement was topically \\
applied, and cured for \\
one week \\
\end{tabular} & $20 \%$ & $145 \%$ \\
\hline $\begin{array}{c}\text { Geotrail } \\
\text { Lot } 3\end{array}$ & 9/17/2019 & 0.203 & 0.256 & 0.459 & $\begin{array}{c}\text { A slurry of } 7 \mathrm{lbs} \text { water, } \\
4.2 \mathrm{lbs} \text { volcanic ash, and } \\
2.8 \mathrm{lbs} \text { of portland cement } \\
\text { was topically applied, and } \\
\text { cured for one week }\end{array}$ & $26 \%$ & $34 \%$ \\
\hline $\begin{array}{c}\text { Geotrail } \\
\text { Lot } 8\end{array}$ & 9/17/2019 & 0.172 & 0.482 & 0.654 & \begin{tabular}{|c|} 
A slurry of $4.2 \mathrm{lbs}$ water, \\
$1.56 \mathrm{lbs}$ volcanic ash, and \\
$1.24 \mathrm{lbs}$ of portland \\
cement was topically \\
applied, and cured for \\
one week \\
\end{tabular} & $35 \%$ & $71 \%$ \\
\hline $\begin{array}{c}\text { Geotrail } \\
\text { Lot } 9\end{array}$ & $9 / 17 / 2019$ & 0.190 & 0.579 & 0.769 & \begin{tabular}{|c|} 
A slurry of 7lbs water, \\
$1.68 \mathrm{lbs}$ volcanic ash, and \\
$1.12 \mathrm{lbs}$ of portland \\
cement was topically \\
applied, and cured for \\
one week \\
\end{tabular} & $21 \%$ & $116 \%$ \\
\hline $\begin{array}{l}\text { Geotrail } \\
\text { Lot } 10\end{array}$ & 9/17/2019 & 0.147 & 0.590 & 0.737 & \begin{tabular}{|c|} 
A slurry of $4.2 \mathrm{lbs}$ water, \\
$1.78 \mathrm{lbs}$ volcanic ash, and \\
$1.02 \mathrm{lbs}$ of portland \\
cement was topically \\
applied, and cured for \\
one week
\end{tabular} & $28 \%$ & $46 \%$ \\
\hline $\begin{array}{l}\text { Geotrail } \\
\text { Lot } 11\end{array}$ & 9/17/2019 & 0.172 & 0.317 & 0.489 & \begin{tabular}{|c|} 
A slurry of $4.9 \mathrm{lbs}$ water, \\
$1.17 \mathrm{lbs}$ volcanic ash, and \\
$0.93 \mathrm{lbs}$ of portland \\
cement was topically \\
applied, and cured for \\
one week
\end{tabular} & $26 \%$ & $105 \%$ \\
\hline $\begin{array}{c}\text { Geotrail } \\
\text { Lot } 12\end{array}$ & 9/17/2019 & 0.168 & 0.450 & 0.618 & \begin{tabular}{|c|} 
A slurry of $4.9 \mathrm{lbs}$ water, \\
$1.26 \mathrm{lbs}$ volcanic ash, and \\
$0.84 \mathrm{lbs}$ of portland \\
cement was topically \\
applied, and cured for \\
one week \\
\end{tabular} & $34 \%$ & $93 \%$ \\
\hline $\begin{array}{c}\text { Geotrail } \\
\text { Lot } 4 \\
\end{array}$ & 9/18/2019 & 0.191 & 0.251 & 0.442 & $\begin{array}{l}\text { Surficially treated with } \\
\text { Klingstone Amber. }\end{array}$ & $44 \%$ & $64 \%$ \\
\hline
\end{tabular}




\begin{tabular}{|c|c|c|c|c|c|c|c|}
\hline \multicolumn{8}{|c|}{ GeoTrail Penetrometer Results } \\
\hline Location & Date & $\begin{array}{c}\text { Avg. } \\
\text { Firmness }\end{array}$ & Avg. Stability & $\begin{array}{c}\text { Avg. Firmness + } \\
\text { Stability }\end{array}$ & Treatment & $\begin{array}{l}\text { Firmness } \\
\text { Variability }\end{array}$ & \begin{tabular}{|c|} 
Stability \\
Variability \\
\end{tabular} \\
\hline $\begin{array}{c}\text { Geotrail } \\
\text { Lot } 5\end{array}$ & 9/18/2019 & 0.157 & 0.276 & 0.433 & $\begin{array}{c}\text { Surficially treated with } \sim 1 \\
\text { gallon of } \mathrm{G} 3 \text { stabilizer }\end{array}$ & $48 \%$ & $42 \%$ \\
\hline $\begin{array}{c}\text { Geotrail } \\
\text { Lot } 6\end{array}$ & 9/19/2019 & 0.173 & 0.236 & 0.409 & $\begin{array}{c}\text { Surficially treated with } \sim 1 \\
\text { gallon of SoilTac Liquid } \\
\text { Topical stabilizer diluted } \\
\text { to a } 30 \% \text { concentration } \\
\text { with water. }\end{array}$ & $18 \%$ & $29 \%$ \\
\hline $\begin{array}{c}\text { Geotrail } \\
\text { Lot } 7\end{array}$ & 9/19/2019 & 0.175 & 0.506 & 0.681 & $\begin{array}{l}\text { A slurry of } 3.5 \mathrm{lbs} \text { water, } \\
1.94 \mathrm{lbs} \text { volcanic ash, and } \\
1.56 \mathrm{lbs} \text { of portland } \\
\text { cement was topically } \\
\text { applied for the second } \\
\text { time after testing. }\end{array}$ & $29 \%$ & $32 \%$ \\
\hline $\begin{array}{c}\text { Geotrail } \\
\text { Lot } 1\end{array}$ & $9 / 24 / 2019$ & 0.188 & 0.345 & 0.533 & \begin{tabular}{|c|} 
A slurry of $9.8 \mathrm{lbs}$ water, \\
$2.66 \mathrm{lbs}$ volcanic ash, and \\
$1.53 \mathrm{lbs}$ of portland \\
cement was topically \\
applied, and cured for \\
one week
\end{tabular} & $23 \%$ & $58 \%$ \\
\hline $\begin{array}{c}\text { Geotrail } \\
\text { Lot } 2\end{array}$ & $9 / 24 / 2019$ & 0.183 & 0.354 & 0.537 & \begin{tabular}{|c|} 
A slurry of 7lbs water, \\
$4.45 \mathrm{lbs}$ volcanic ash, and \\
$2.55 \mathrm{lbs}$ of portland \\
cement was topically \\
applied, and cured for \\
one week \\
\end{tabular} & $27 \%$ & $38 \%$ \\
\hline $\begin{array}{c}\text { Geotrail } \\
\text { Lot } 3\end{array}$ & $9 / 24 / 2019$ & 0.178 & 0.259 & 0.437 & $\begin{array}{c}\text { A slurry of } 7 \mathrm{lbs} \text { water, } \\
4.2 \mathrm{lbs} \text { volcanic ash, and } \\
2.8 \mathrm{lbs} \text { of portland cement } \\
\text { was topically applied, and } \\
\text { cured for one week }\end{array}$ & $2677 \%$ & $132 \%$ \\
\hline $\begin{array}{c}\text { Geotrail } \\
\text { Lot } 8\end{array}$ & $9 / 24 / 2019$ & 0.182 & 0.569 & 0.751 & \begin{tabular}{|c|} 
A slurry of $4.2 \mathrm{lbs}$ water, \\
$1.56 \mathrm{lbs}$ volcanic ash, and \\
$1.24 \mathrm{lbs}$ of portland \\
cement was topically \\
applied, and cured for \\
one week \\
\end{tabular} & $27 \%$ & $75 \%$ \\
\hline $\begin{array}{c}\text { Geotrail } \\
\text { Lot } 9\end{array}$ & $9 / 24 / 2019$ & 0.159 & 0.406 & 0.565 & \begin{tabular}{|c|} 
A slurry of 7lbs water, \\
$1.68 \mathrm{lbs}$ volcanic ash, and \\
$1.12 \mathrm{lbs}$ of portland \\
cement was topically \\
applied, and cured for \\
one week \\
\end{tabular} & $15 \%$ & $100 \%$ \\
\hline $\begin{array}{c}\text { Geotrail } \\
\text { Lot } 10\end{array}$ & $9 / 24 / 2019$ & 0.166 & 0.545 & 0.711 & \begin{tabular}{|c|} 
A slurry of $4.2 \mathrm{lbs}$ water, \\
$1.78 \mathrm{lbs}$ volcanic ash, and \\
$1.02 \mathrm{lbs}$ of portland \\
cement was topically \\
applied, and cured for \\
one week \\
\end{tabular} & $38 \%$ & $70 \%$ \\
\hline
\end{tabular}




\begin{tabular}{|c|c|c|c|c|c|c|c|}
\hline \multicolumn{8}{|c|}{ GeoTrail Penetrometer Results } \\
\hline Location & Date & \begin{tabular}{|c|} 
Avg. \\
Firmness \\
\end{tabular} & Avg. Stability & $\begin{array}{c}\text { Avg. Firmness + } \\
\text { Stability }\end{array}$ & Treatment & \begin{tabular}{|c|} 
Firmness \\
Variability
\end{tabular} & \begin{tabular}{|c|} 
Stability \\
Variability \\
\end{tabular} \\
\hline $\begin{array}{l}\text { Geotrail } \\
\text { Lot } 11\end{array}$ & $9 / 24 / 2019$ & 0.185 & 0.307 & 0.492 & $\begin{array}{c}\text { A slurry of 4.9lbs water, } \\
1.17 \mathrm{lbs} \text { volcanic ash, and } \\
0.93 \mathrm{lbs} \text { of portland } \\
\text { cement was topically } \\
\text { applied, and cured for } \\
\text { one week }\end{array}$ & $38 \%$ & $58 \%$ \\
\hline $\begin{array}{c}\text { Geotrail } \\
\text { Lot } 12\end{array}$ & 9/24/2019 & 0.171 & 0.459 & 0.630 & $\begin{array}{l}\text { A slurry of 4.9lbs water, } \\
1.26 \mathrm{lbs} \text { volcanic ash, and } \\
0.84 \mathrm{lbs} \text { of portland } \\
\text { cement was topically } \\
\text { applied, and cured for } \\
\text { one week }\end{array}$ & $27 \%$ & $121 \%$ \\
\hline \begin{tabular}{|c|} 
Geotrail \\
Lot 4 \\
\end{tabular} & 9/25/2019 & 0.174 & 0.180 & 0.354 & $\begin{array}{l}\text { Surficially treated with } \\
\text { Klingstone Amber. }\end{array}$ & $33 \%$ & $99 \%$ \\
\hline $\begin{array}{l}\text { Geotrail } \\
\text { Lot } 5\end{array}$ & $9 / 25 / 2019$ & 0.156 & 0.316 & 0.472 & $\begin{array}{l}\text { Surficially treated with } \sim 1 \\
\text { gallon of G3 stabilizer }\end{array}$ & $23 \%$ & $36 \%$ \\
\hline $\begin{array}{l}\text { Geotrail } \\
\text { Lot } 6\end{array}$ & 9/26/2019 & 0.150 & 0.239 & 0.389 & $\begin{array}{l}\text { Surficially treated with } \sim 1 \\
\text { gallon of SoilTac Liquid } \\
\text { Topical stabilizer diluted } \\
\text { to a } 30 \% \text { concentration } \\
\text { with water. }\end{array}$ & $34 \%$ & $36 \%$ \\
\hline $\begin{array}{c}\text { Geotrail } \\
\text { Lot } 7\end{array}$ & 9/26/2019 & 0.168 & 0.448 & 0.616 & $\begin{array}{l}\text { A slurry of } 3.5 \mathrm{lbs} \text { water, } \\
1.94 \mathrm{lbs} \text { volcanic ash, and } \\
1.56 \mathrm{lbs} \text { of portland } \\
\text { cement was topically } \\
\text { applied for the second } \\
\text { time after testing. }\end{array}$ & $21 \%$ & $21 \%$ \\
\hline $\begin{array}{c}\text { Geotrail } \\
\text { Lot } 1\end{array}$ & $10 / 1 / 2019$ & 0.172 & 0.269 & 0.441 & $\begin{array}{c}\text { A slurry of } 9.8 \mathrm{lbs} \text { water, } \\
2.66 \mathrm{lbs} \text { volcanic ash, and } \\
1.53 \mathrm{lbs} \text { of portland } \\
\text { cement was topically } \\
\text { applied, and cured for } \\
\text { one week }\end{array}$ & $36 \%$ & $68 \%$ \\
\hline $\begin{array}{c}\text { Geotrail } \\
\text { Lot } 2\end{array}$ & $10 / 1 / 2019$ & 0.195 & 0.270 & 0.465 & $\begin{array}{c}\text { A slurry of 7lbs water, } \\
4.45 \mathrm{lbs} \text { volcanic ash, and } \\
2.55 \mathrm{lbs} \text { of portland } \\
\text { cement was topically } \\
\text { applied, and cured for } \\
\text { one week }\end{array}$ & $12 \%$ & $32 \%$ \\
\hline $\begin{array}{c}\text { Geotrail } \\
\text { Lot } 3\end{array}$ & $10 / 1 / 2019$ & 0.189 & 0.217 & 0.406 & $\begin{array}{c}\text { A slurry of } 7 \mathrm{lbs} \text { water, } \\
4.2 \mathrm{lbs} \text { volcanic ash, and } \\
2.8 \mathrm{lbs} \text { of portland cement } \\
\text { was topically applied, and } \\
\text { cured for one week }\end{array}$ & $30 \%$ & $53 \%$ \\
\hline
\end{tabular}




\begin{tabular}{|c|c|c|c|c|c|c|c|}
\hline \multicolumn{8}{|c|}{ GeoTrail Penetrometer Results } \\
\hline Location & Date & $\begin{array}{c}\text { Avg. } \\
\text { Firmness }\end{array}$ & Avg. Stability & $\begin{array}{c}\text { Avg. Firmness + } \\
\text { Stability }\end{array}$ & Treatment & $\begin{array}{c}\text { Firmness } \\
\text { Variability }\end{array}$ & \begin{tabular}{|c|} 
Stability \\
Variability \\
\end{tabular} \\
\hline $\begin{array}{c}\text { Geotrail } \\
\text { Lot } 8\end{array}$ & $10 / 1 / 2019$ & 0.169 & 0.537 & 0.706 & \begin{tabular}{|c|} 
A slurry of $4.2 \mathrm{lbs}$ water, \\
$1.56 \mathrm{lbs}$ volcanic ash, and \\
$1.24 \mathrm{lbs}$ of portland \\
cement was topically \\
applied, and cured for \\
one week \\
\end{tabular} & $72 \%$ & $86 \%$ \\
\hline $\begin{array}{c}\text { Geotrail } \\
\text { Lot } 9\end{array}$ & $10 / 1 / 2019$ & 0.159 & 0.410 & 0.569 & \begin{tabular}{|c|} 
A slurry of $7 \mathrm{lbs}$ water, \\
$1.68 \mathrm{lbs}$ volcanic ash, and \\
$1.12 \mathrm{lbs}$ of portland \\
cement was topically \\
applied, and cured for \\
one week
\end{tabular} & $26 \%$ & $83 \%$ \\
\hline $\begin{array}{c}\text { Geotrail } \\
\text { Lot } 10\end{array}$ & $10 / 1 / 2019$ & 0.155 & 0.510 & 0.665 & \begin{tabular}{|c|} 
A slurry of $4.2 \mathrm{lbs}$ water, \\
$1.78 \mathrm{lbs}$ volcanic ash, and \\
$1.02 \mathrm{lbs}$ of portland \\
cement was topically \\
applied, and cured for \\
one week \\
\end{tabular} & $38 \%$ & $35 \%$ \\
\hline $\begin{array}{c}\text { Geotrail } \\
\text { Lot } 11\end{array}$ & $10 / 1 / 2019$ & 0.176 & 0.394 & 0.570 & \begin{tabular}{|c|} 
A slurry of $4.9 \mathrm{lbs}$ water, \\
$1.17 \mathrm{lbs}$ volcanic ash, and \\
$0.93 \mathrm{lbs}$ of portland \\
cement was topically \\
applied, and cured for \\
one week \\
\end{tabular} & $22 \%$ & $61 \%$ \\
\hline $\begin{array}{c}\text { Geotrail } \\
\text { Lot } 12\end{array}$ & $10 / 1 / 2019$ & 0.169 & 0.463 & 0.632 & \begin{tabular}{|c|} 
A slurry of 4.9lbs water, \\
$1.26 \mathrm{lbs}$ volcanic ash, and \\
$0.84 \mathrm{lbs}$ of portland \\
cement was topically \\
applied, and cured for \\
one week \\
\end{tabular} & $36 \%$ & $85 \%$ \\
\hline $\begin{array}{c}\text { Geotrail } \\
\text { Lot } 4 \\
\end{array}$ & $10 / 2 / 2019$ & 0.199 & 0.254 & 0.453 & $\begin{array}{c}\text { Surficially treated with } \\
\text { Klingstone Amber. }\end{array}$ & $48 \%$ & $33 \%$ \\
\hline $\begin{array}{l}\text { Geotrail } \\
\text { Lot } 5\end{array}$ & $10 / 2 / 2019$ & 0.171 & 0.266 & 0.437 & $\begin{array}{c}\text { Surficially treated with } \sim 1 \\
\text { gallon of } G 3 \text { stabilizer }\end{array}$ & $36 \%$ & $82 \%$ \\
\hline $\begin{array}{c}\text { Geotrail } \\
\text { Lot } 6\end{array}$ & $10 / 3 / 2019$ & 0.171 & 0.277 & 0.448 & $\begin{array}{c}\text { Surficially treated with } \sim 1 \\
\text { gallon of SoilTac Liquid } \\
\text { Topical stabilizer diluted } \\
\text { to a } 30 \% \text { concentration } \\
\text { with water. }\end{array}$ & $19 \%$ & $33 \%$ \\
\hline $\begin{array}{c}\text { Geotrail } \\
\text { Lot } 7\end{array}$ & $10 / 3 / 2019$ & 0.143 & 0.425 & 0.568 & $\begin{array}{l}\text { A slurry of } 3.5 \mathrm{lbs} \text { water, } \\
1.94 \mathrm{lbs} \text { volcanic ash, and } \\
1.56 \mathrm{lbs} \text { of portland } \\
\text { cement was topically } \\
\text { applied for the second } \\
\text { time after testing. }\end{array}$ & $21 \%$ & $32 \%$ \\
\hline
\end{tabular}




\begin{tabular}{|c|c|c|c|c|c|c|c|}
\hline \multicolumn{8}{|c|}{ GeoTrail Penetrometer Results } \\
\hline Location & Date & $\begin{array}{c}\text { Avg. } \\
\text { Firmness }\end{array}$ & Avg. Stability & $\begin{array}{c}\text { Avg. Firmness + } \\
\text { Stability }\end{array}$ & Treatment & $\begin{array}{c}\text { Firmness } \\
\text { Variability }\end{array}$ & \begin{tabular}{|c|} 
Stability \\
Variability
\end{tabular} \\
\hline $\begin{array}{l}\text { Geotrail } \\
\text { Lot } 1\end{array}$ & $10 / 8 / 2019$ & 0.166 & 0.513 & 0.679 & $\begin{array}{c}\text { A slurry of } 9.8 \mathrm{lbs} \text { water, } \\
2.66 \mathrm{lbs} \text { volcanic ash, and } \\
1.53 \mathrm{lbs} \text { of portland } \\
\text { cement was topically } \\
\text { applied, and cured for } \\
\text { one week }\end{array}$ & $63 \%$ & $33 \%$ \\
\hline $\begin{array}{l}\text { Geotrail } \\
\text { Lot } 2\end{array}$ & $10 / 8 / 2019$ & 0.165 & 0.341 & 0.506 & \begin{tabular}{|c|} 
A slurry of 7lbs water, \\
$4.45 \mathrm{lbs}$ volcanic ash, and \\
$2.55 \mathrm{lbs}$ of portland \\
cement was topically \\
applied, and cured for \\
one week \\
\end{tabular} & $29 \%$ & $94 \%$ \\
\hline $\begin{array}{c}\text { Geotrail } \\
\text { Lot } 3\end{array}$ & $10 / 8 / 2019$ & 0.176 & 0.221 & 0.397 & $\begin{array}{c}\text { A slurry of } 7 \mathrm{lbs} \text { water, } \\
4.2 \mathrm{lbs} \text { volcanic ash, and } \\
2.8 \mathrm{lbs} \text { of portland cement } \\
\text { was topically applied, and } \\
\text { cured for one week }\end{array}$ & $27 \%$ & $86 \%$ \\
\hline $\begin{array}{c}\text { Geotrail } \\
\text { Lot } 8\end{array}$ & $10 / 8 / 2019$ & 0.162 & 0.530 & 0.692 & $\begin{array}{c}\text { A slurry of } 4.2 \mathrm{lbs} \text { water, } \\
1.56 \mathrm{lbs} \text { volcanic ash, and } \\
1.24 \mathrm{lbs} \text { of portland } \\
\text { cement was topically } \\
\text { applied, and cured for } \\
\text { one week }\end{array}$ & $16 \%$ & $53 \%$ \\
\hline $\begin{array}{c}\text { Geotrail } \\
\text { Lot } 9\end{array}$ & $10 / 8 / 2019$ & 0.159 & 0.518 & 0.677 & $\begin{array}{c}\text { A slurry of 7lbs water, } \\
1.68 \mathrm{lbs} \text { volcanic ash, and } \\
1.12 \mathrm{lbs} \text { of portland } \\
\text { cement was topically } \\
\text { applied, and cured for } \\
\text { one week }\end{array}$ & $72 \%$ & $83 \%$ \\
\hline $\begin{array}{l}\text { Geotrail } \\
\text { Lot } 10\end{array}$ & $10 / 8 / 2019$ & 0.140 & 0.514 & 0.654 & \begin{tabular}{|} 
A slurry of $4.2 \mathrm{lbs}$ water, \\
$1.78 \mathrm{lbs}$ volcanic ash, and \\
$1.02 \mathrm{lbs}$ of portland \\
cement was topically \\
applied, and cured for \\
one week
\end{tabular} & $22 \%$ & $43 \%$ \\
\hline $\begin{array}{c}\text { Geotrail } \\
\text { Lot } 11\end{array}$ & $10 / 8 / 2019$ & 0.148 & 0.478 & 0.626 & $\begin{array}{l}\text { A slurry of } 4.9 \mathrm{lbs} \text { water, } \\
1.17 \mathrm{lbs} \text { volcanic ash, and } \\
0.93 \mathrm{lbs} \text { of portland } \\
\text { cement was topically } \\
\text { applied, and cured for } \\
\text { one week }\end{array}$ & $24 \%$ & $28 \%$ \\
\hline
\end{tabular}




\begin{tabular}{|c|c|c|c|c|c|c|c|}
\hline \multicolumn{8}{|c|}{ GeoTrail Penetrometer Results } \\
\hline Location & Date & $\begin{array}{c}\text { Avg. } \\
\text { Firmness }\end{array}$ & Avg. Stability & $\begin{array}{c}\text { Avg. Firmness + } \\
\text { Stability }\end{array}$ & Treatment & $\begin{array}{c}\text { Firmness } \\
\text { Variability }\end{array}$ & \begin{tabular}{|c|} 
Stability \\
Variability \\
\end{tabular} \\
\hline $\begin{array}{c}\text { Geotrail } \\
\text { Lot } 12\end{array}$ & $10 / 8 / 2019$ & 0.154 & 0.505 & 0.659 & \begin{tabular}{|c|} 
A slurry of $4.9 \mathrm{lbs}$ water, \\
$1.26 \mathrm{lbs}$ volcanic ash, and \\
$0.84 \mathrm{lbs}$ of portland \\
cement was topically \\
applied, and cured for \\
one week \\
\end{tabular} & $37 \%$ & $54 \%$ \\
\hline $\begin{array}{c}\text { Geotrail } \\
\text { Lot } 4 \\
\end{array}$ & $10 / 9 / 2019$ & 0.188 & 0.199 & 0.387 & $\begin{array}{l}\text { Surficially treated with } \\
\text { Klingstone Amber. }\end{array}$ & $39 \%$ & $45 \%$ \\
\hline $\begin{array}{l}\text { Geotrail } \\
\text { Lot } 5\end{array}$ & $10 / 9 / 2019$ & 0.170 & 0.308 & 0.478 & $\begin{array}{c}\text { Surficially treated with } \sim 1 \\
\text { gallon of } G 3 \text { stabilizer }\end{array}$ & $44 \%$ & $59 \%$ \\
\hline $\begin{array}{l}\text { Geotrail } \\
\text { Lot } 6\end{array}$ & $10 / 10 / 2019$ & 0.176 & 0.277 & 0.453 & $\begin{array}{c}\text { Surficially treated with } \sim 1 \\
\text { gallon of SoilTac Liquid } \\
\text { Topical stabilizer diluted } \\
\text { to a } 30 \% \text { concentration } \\
\text { with water. }\end{array}$ & $22 \%$ & $31 \%$ \\
\hline $\begin{array}{c}\text { Geotrail } \\
\text { Lot } 7\end{array}$ & $10 / 10 / 2019$ & 0.152 & 0.512 & 0.664 & $\begin{array}{l}\text { A slurry of } 3.5 \mathrm{lbs} \text { water, } \\
1.94 \mathrm{lbs} \text { volcanic ash, and } \\
1.56 \mathrm{lbs} \text { of portland } \\
\text { cement was topically } \\
\text { applied for the second } \\
\text { time after testing. }\end{array}$ & $35 \%$ & $48 \%$ \\
\hline $\begin{array}{c}\text { Geotrail } \\
\text { Lot } 1\end{array}$ & $10 / 15 / 0219$ & 0.146 & 0.469 & 0.615 & \begin{tabular}{|c|} 
A slurry of $9.8 \mathrm{lbs}$ water, \\
$2.66 \mathrm{lbs}$ volcanic ash, and \\
$1.53 \mathrm{lbs}$ of portland \\
cement was topically \\
applied, and cured for \\
one week
\end{tabular} & $44 \%$ & $94 \%$ \\
\hline $\begin{array}{c}\text { Geotrail } \\
\text { Lot } 2\end{array}$ & $10 / 15 / 2019$ & 0.158 & 0.200 & 0.358 & \begin{tabular}{|c|} 
A slurry of $7 \mathrm{lbs}$ water, \\
$4.45 \mathrm{lbs}$ volcanic ash, and \\
$2.55 \mathrm{lbs}$ of portland \\
cement was topically \\
applied, and cured for \\
one week \\
\end{tabular} & $36 \%$ & $128 \%$ \\
\hline $\begin{array}{c}\text { Geotrail } \\
\text { Lot } 3\end{array}$ & $10 / 15 / 2019$ & 0.173 & 0.258 & 0.431 & $\begin{array}{c}\text { A slurry of } 7 \mathrm{lbs} \text { water, } \\
4.2 \mathrm{lbs} \text { volcanic ash, and } \\
2.8 \mathrm{lbs} \text { of portland cement } \\
\text { was topically applied, and } \\
\text { cured for one week }\end{array}$ & $34 \%$ & $113 \%$ \\
\hline $\begin{array}{c}\text { Geotrail } \\
\text { Lot } 8\end{array}$ & $10 / 15 / 2019$ & 0.185 & 0.667 & 0.852 & \begin{tabular}{|c|} 
A slurry of $4.2 \mathrm{lbs}$ water, \\
$1.56 \mathrm{lbs}$ volcanic ash, and \\
$1.24 \mathrm{lbs}$ of portland \\
cement was topically \\
applied, and cured for \\
one week
\end{tabular} & $36 \%$ & $91 \%$ \\
\hline
\end{tabular}




\begin{tabular}{|c|c|c|c|c|c|c|c|}
\hline \multicolumn{8}{|c|}{ GeoTrail Penetrometer Results } \\
\hline Location & Date & $\begin{array}{c}\text { Avg. } \\
\text { Firmness }\end{array}$ & Avg. Stability & $\begin{array}{l}\text { Avg. Firmness + } \\
\text { Stability }\end{array}$ & Treatment & $\begin{array}{c}\text { Firmness } \\
\text { Variability }\end{array}$ & \begin{tabular}{|c|} 
Stability \\
Variability
\end{tabular} \\
\hline $\begin{array}{c}\text { Geotrail } \\
\text { Lot } 9\end{array}$ & $10 / 15 / 2019$ & 0.153 & 0.562 & 0.715 & \begin{tabular}{|c|} 
A slurry of $7 \mathrm{lbs}$ water, \\
$1.68 \mathrm{lbs}$ volcanic ash, and \\
$1.12 \mathrm{lbs}$ of portland \\
cement was topically \\
applied, and cured for \\
one week
\end{tabular} & $19 \%$ & $41 \%$ \\
\hline $\begin{array}{l}\text { Geotrail } \\
\text { Lot } 10\end{array}$ & $10 / 15 / 2019$ & 0.176 & 0.590 & 0.766 & \begin{tabular}{|c|} 
A slurry of $4.2 \mathrm{lbs}$ water, \\
$1.78 \mathrm{lbs}$ volcanic ash, and \\
$1.02 \mathrm{lbs}$ of portland \\
cement was topically \\
applied, and cured for \\
one week
\end{tabular} & $56 \%$ & $57 \%$ \\
\hline $\begin{array}{c}\text { Geotrail } \\
\text { Lot } 11\end{array}$ & $10 / 15 / 2019$ & 0.150 & 0.596 & 0.746 & \begin{tabular}{|c|} 
A slurry of $4.9 \mathrm{lbs}$ water, \\
$1.17 \mathrm{lbs}$ volcanic ash, and \\
$0.93 \mathrm{lbs}$ of portland \\
cement was topically \\
applied, and cured for \\
one week \\
\end{tabular} & $53 \%$ & $52 \%$ \\
\hline $\begin{array}{c}\text { Geotrail } \\
\text { Lot } 12\end{array}$ & $10 / 15 / 2019$ & 0.163 & 0.576 & 0.739 & \begin{tabular}{|c|} 
A slurry of $4.9 \mathrm{lbs}$ water, \\
$1.26 \mathrm{lbs}$ volcanic ash, and \\
$0.84 \mathrm{lbs}$ of portland \\
cement was topically \\
applied, and cured for \\
one week \\
\end{tabular} & $32 \%$ & $85 \%$ \\
\hline $\begin{array}{c}\text { Geotrail } \\
\text { Lot } 4 \\
\end{array}$ & $10 / 16 / 2019$ & 0.161 & 0.206 & 0.367 & $\begin{array}{l}\text { Surficially treated with } \\
\text { Klingstone Amber. }\end{array}$ & $22 \%$ & $18 \%$ \\
\hline $\begin{array}{c}\text { Geotrail } \\
\text { Lot } 5\end{array}$ & $10 / 16 / 2019$ & 0.145 & 0.264 & 0.409 & $\begin{array}{l}\text { Surficially treated with } \sim 1 \\
\text { gallon of } \mathrm{G} 3 \text { stabilizer }\end{array}$ & $36 \%$ & $63 \%$ \\
\hline $\begin{array}{l}\text { Geotrail } \\
\text { Lot } 6\end{array}$ & $10 / 17 / 2019$ & 0.170 & 0.265 & 0.435 & $\begin{array}{c}\text { Surficially treated with } \sim 1 \\
\text { gallon of SoilTac Liquid } \\
\text { Topical stabilizer diluted } \\
\text { to a } 30 \% \text { concentration } \\
\text { with water. }\end{array}$ & $44 \%$ & $40 \%$ \\
\hline $\begin{array}{l}\text { Geotrail } \\
\text { Lot } 7\end{array}$ & $10 / 17 / 2019$ & 0.151 & 0.424 & 0.575 & $\begin{array}{l}\text { A slurry of } 3.5 \mathrm{lbs} \text { water, } \\
1.94 \mathrm{lbs} \text { volcanic ash, and } \\
1.56 \mathrm{lbs} \text { of portland } \\
\text { cement was topically } \\
\text { applied for the second } \\
\text { time after testing. }\end{array}$ & $47 \%$ & $65 \%$ \\
\hline $\begin{array}{c}\text { Geotrail } \\
\text { Lot } 1\end{array}$ & $10 / 22 / 2019$ & 0.144 & 0.369 & 0.513 & \begin{tabular}{|c|} 
A slurry of $9.8 \mathrm{lbs}$ water, \\
$2.66 \mathrm{lbs}$ volcanic ash, and \\
$1.53 \mathrm{lbs}$ of portland \\
cement was topically \\
applied, and cured for \\
one week \\
\end{tabular} & $16 \%$ & $22 \%$ \\
\hline
\end{tabular}




\begin{tabular}{|c|c|c|c|c|c|c|c|}
\hline \multicolumn{8}{|c|}{ GeoTrail Penetrometer Results } \\
\hline Location & Date & $\begin{array}{c}\text { Avg. } \\
\text { Firmness }\end{array}$ & Avg. Stability & $\begin{array}{c}\text { Avg. Firmness + } \\
\text { Stability }\end{array}$ & Treatment & $\begin{array}{c}\text { Firmness } \\
\text { Variability }\end{array}$ & $\begin{array}{c}\text { Stability } \\
\text { Variability }\end{array}$ \\
\hline $\begin{array}{c}\text { Geotrail } \\
\text { Lot } 2\end{array}$ & $10 / 22 / 2019$ & 0.145 & 0.319 & 0.464 & \begin{tabular}{|c|} 
A slurry of 7lbs water, \\
$4.45 \mathrm{lbs}$ volcanic ash, and \\
$2.55 \mathrm{lbs}$ of portland \\
cement was topically \\
applied, and cured for \\
one week \\
\end{tabular} & $62 \%$ & $111 \%$ \\
\hline $\begin{array}{c}\text { Geotrail } \\
\text { Lot } 3\end{array}$ & $10 / 22 / 2019$ & 0.161 & 0.221 & 0.382 & $\begin{array}{c}\text { A slurry of } 7 \mathrm{lbs} \text { water, } \\
4.2 \mathrm{lbs} \text { volcanic ash, and } \\
2.8 \mathrm{lbs} \text { of portland cement } \\
\text { was topically applied, and } \\
\text { cured for one week }\end{array}$ & $13 \%$ & $114 \%$ \\
\hline $\begin{array}{c}\text { Geotrail } \\
\text { Lot } 8\end{array}$ & $10 / 22 / 2019$ & 0.156 & 0.598 & 0.754 & $\begin{array}{c}\text { A slurry of } 4.2 \mathrm{lbs} \text { water, } \\
1.56 \mathrm{lbs} \text { volcanic ash, and } \\
1.24 \mathrm{lbs} \text { of portland } \\
\text { cement was topically } \\
\text { applied, and cured for } \\
\text { one week } \\
\end{array}$ & $23 \%$ & $60 \%$ \\
\hline $\begin{array}{c}\text { Geotrail } \\
\text { Lot } 9\end{array}$ & $10 / 22 / 2019$ & 0.166 & 0.446 & 0.612 & $\begin{array}{c}\text { A slurry of } 7 \mathrm{lbs} \text { water, } \\
1.68 \mathrm{lbs} \text { volcanic ash, and } \\
1.12 \mathrm{lbs} \text { of portland } \\
\text { cement was topically } \\
\text { applied, and cured for } \\
\text { one week }\end{array}$ & $36 \%$ & $75 \%$ \\
\hline $\begin{array}{l}\text { Geotrail } \\
\text { Lot } 10\end{array}$ & $10 / 22 / 2019$ & 0.163 & 0.428 & 0.591 & $\begin{array}{c}\text { A slurry of } 4.2 \mathrm{lbs} \text { water, } \\
1.78 \mathrm{lbs} \text { volcanic ash, and } \\
1.02 \mathrm{lbs} \text { of portland } \\
\text { cement was topically } \\
\text { applied, and cured for } \\
\text { one week } \\
\end{array}$ & $21 \%$ & $51 \%$ \\
\hline $\begin{array}{l}\text { Geotrail } \\
\text { Lot } 11\end{array}$ & $10 / 22 / 2019$ & 0.162 & 0.414 & 0.576 & $\begin{array}{c}\text { A slurry of } 4.9 \mathrm{lbs} \text { water, } \\
1.17 \mathrm{lbs} \text { volcanic ash, and } \\
0.93 \mathrm{lbs} \text { of portland } \\
\text { cement was topically } \\
\text { applied, and cured for } \\
\text { one week }\end{array}$ & $26 \%$ & $18 \%$ \\
\hline $\begin{array}{c}\text { Geotrail } \\
\text { Lot } 12\end{array}$ & $10 / 22 / 2019$ & 0.164 & 0.411 & 0.575 & \begin{tabular}{|c|} 
A slurry of $4.9 \mathrm{lbs}$ water, \\
$1.26 \mathrm{lbs}$ volcanic ash, and \\
$0.84 \mathrm{lbs}$ of portland \\
cement was topically \\
applied, and cured for \\
one week
\end{tabular} & $8 \%$ & $91 \%$ \\
\hline
\end{tabular}




\begin{tabular}{|c|c|c|c|c|c|c|c|}
\hline \multicolumn{8}{|c|}{ GeoTrail Penetrometer Results } \\
\hline Location & Date & \begin{tabular}{|c|} 
Avg. \\
Firmness \\
\end{tabular} & Avg. Stability & $\begin{array}{c}\text { Avg. Firmness + } \\
\text { Stability }\end{array}$ & Treatment & \begin{tabular}{|c|} 
Firmness \\
Variability
\end{tabular} & \begin{tabular}{|c|} 
Stability \\
Variability \\
\end{tabular} \\
\hline $\begin{array}{c}\text { Geotrail } \\
\text { Lot } 4 \\
\end{array}$ & $10 / 23 / 2019$ & 0.164 & 0.411 & 0.575 & $\begin{array}{c}\text { Surficially treated with } \\
\text { Klingstone Amber. }\end{array}$ & $8 \%$ & $91 \%$ \\
\hline $\begin{array}{l}\text { Geotrail } \\
\text { Lot } 5\end{array}$ & $10 / 23 / 2019$ & 0.163 & 0.320 & 0.483 & $\begin{array}{c}\text { Surficially treated with } \sim 1 \\
\text { gallon of } G 3 \text { stabilizer }\end{array}$ & $34 \%$ & $23 \%$ \\
\hline $\begin{array}{l}\text { Geotrail } \\
\text { Lot } 6\end{array}$ & $10 / 24 / 2019$ & 0.162 & 0.255 & 0.417 & $\begin{array}{c}\text { Surficially treated with } \sim 1 \\
\text { gallon of SoilTac Liquid } \\
\text { Topical stabilizer diluted } \\
\text { to a } 30 \% \text { concentration } \\
\text { with water. }\end{array}$ & $19 \%$ & $39 \%$ \\
\hline $\begin{array}{l}\text { Geotrail } \\
\text { Lot } 7\end{array}$ & $10 / 24 / 2019$ & 0.158 & 0.414 & 0.572 & $\begin{array}{l}\text { A slurry of } 3.5 \mathrm{lbs} \text { water, } \\
1.94 \mathrm{lbs} \text { volcanic ash, and } \\
1.56 \mathrm{lbs} \text { of portland } \\
\text { cement was topically } \\
\text { applied for the second } \\
\text { time after testing. }\end{array}$ & $19 \%$ & $32 \%$ \\
\hline $\begin{array}{l}\text { Geotrail } \\
\text { Lot } 8\end{array}$ & $10 / 29 / 2019$ & 0.147 & 0.490 & 0.637 & $\begin{array}{c}\text { A slurry of 4.2lbs water, } \\
1.56 \mathrm{lbs} \text { volcanic ash, and } \\
1.24 \mathrm{lbs} \text { of portland } \\
\text { cement was topically } \\
\text { applied, and cured for } \\
\text { one week }\end{array}$ & $21 \%$ & $24 \%$ \\
\hline $\begin{array}{l}\text { Geotrail } \\
\text { Lot } 9\end{array}$ & $10 / 29 / 2019$ & 0.156 & 0.555 & 0.711 & $\begin{array}{c}\text { A slurry of 7lbs water, } \\
1.68 \mathrm{lbs} \text { volcanic ash, and } \\
1.12 \mathrm{lbs} \text { of portland } \\
\text { cement was topically } \\
\text { applied, and cured for } \\
\text { one week }\end{array}$ & $31 \%$ & $52 \%$ \\
\hline $\begin{array}{l}\text { Geotrail } \\
\text { Lot } 10\end{array}$ & $10 / 29 / 2019$ & 0.157 & 0.496 & 0.653 & $\begin{array}{c}\text { A slurry of } 4.2 \mathrm{lbs} \text { water, } \\
1.78 \mathrm{lbs} \text { volcanic ash, and } \\
1.02 \mathrm{lbs} \text { of portland } \\
\text { cement was topically } \\
\text { applied, and cured for } \\
\text { one week }\end{array}$ & $25 \%$ & $48 \%$ \\
\hline $\begin{array}{l}\text { Geotrail } \\
\text { Lot } 11\end{array}$ & $10 / 29 / 2019$ & 0.145 & 0.473 & 0.618 & $\begin{array}{c}\text { A slurry of 4.9lbs water, } \\
1.17 \mathrm{lbs} \text { volcanic ash, and } \\
0.93 \mathrm{lbs} \text { of portland } \\
\text { cement was topically } \\
\text { applied, and cured for } \\
\text { one week }\end{array}$ & $32 \%$ & $28 \%$ \\
\hline $\begin{array}{l}\text { Geotrail } \\
\text { Lot } 12\end{array}$ & $10 / 29 / 2019$ & 0.140 & 0.559 & 0.699 & $\begin{array}{c}\text { A slurry of 4.9lbs water, } \\
1.26 \mathrm{lbs} \text { volcanic ash, and } \\
0.84 \mathrm{lbs} \text { of portland } \\
\text { cement was topically } \\
\text { applied, and cured for } \\
\text { one week }\end{array}$ & $53 \%$ & $91 \%$ \\
\hline
\end{tabular}




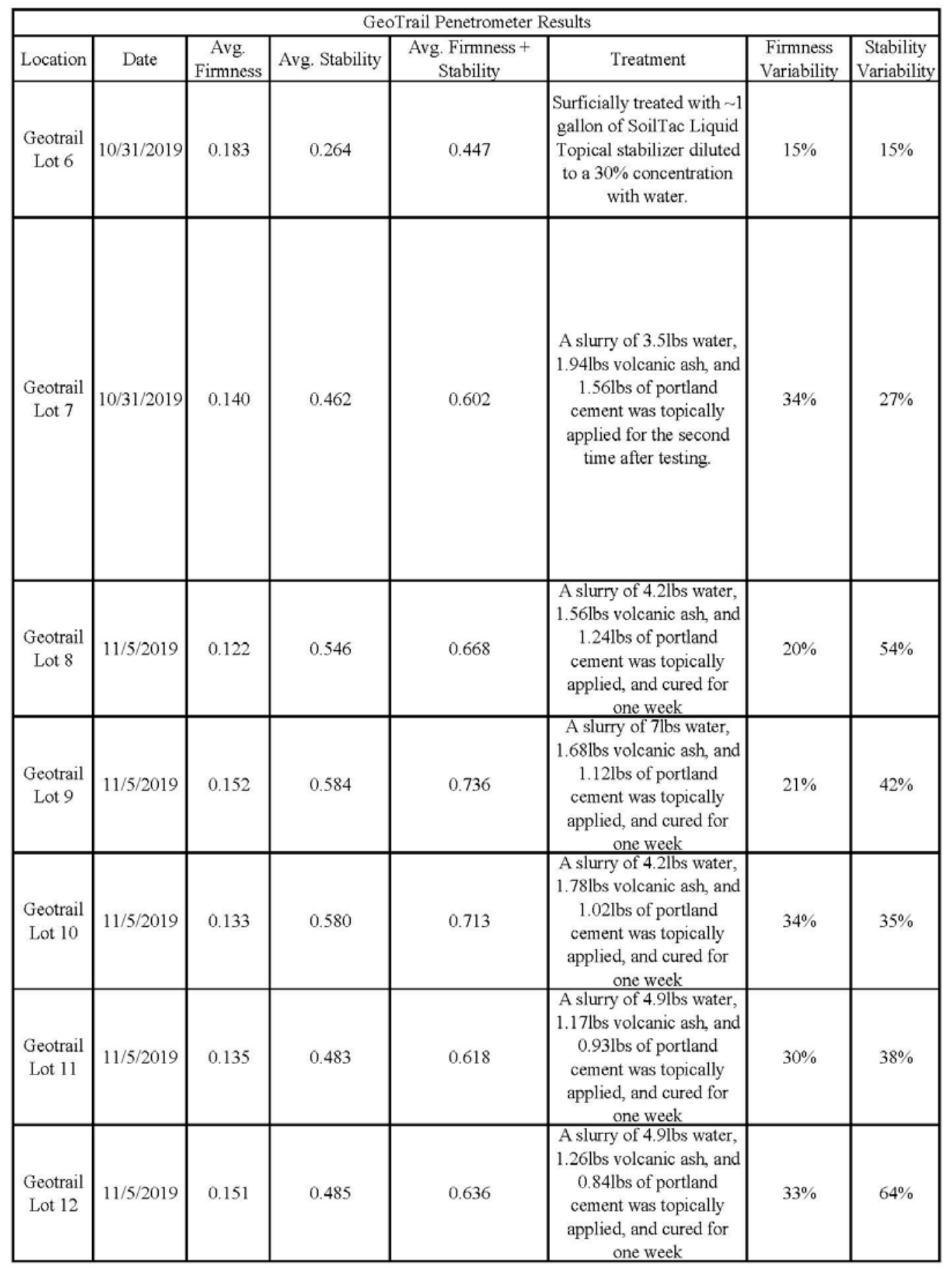




\begin{tabular}{|c|c|c|c|c|c|c|c|}
\hline \multicolumn{7}{|c|}{ GeoTrail Penetrometer Results } \\
\hline Location & Date & $\begin{array}{c}\text { Avg. } \\
\text { Firmness }\end{array}$ & Avg. Stability & $\begin{array}{c}\text { Avg. Firmness }+ \\
\text { Stability }\end{array}$ & Treatment & $\begin{array}{c}\text { Firmness } \\
\text { Variability }\end{array}$ & $\begin{array}{c}\text { Stability } \\
\text { Variability }\end{array}$ \\
\hline $\begin{array}{c}\text { Geotrail } \\
\text { Lot 6 }\end{array}$ & $11 / 7 / 2019$ & 0.153 & 0.271 & 0.424 & $\begin{array}{c}\text { Surficially treated with } \sim 1 \\
\text { gallon of SoilTac Liquid } \\
\text { Topical stabilizer diluted } \\
\text { to a 30\% concentration } \\
\text { with water. }\end{array}$ & $55 \%$ & $43 \%$ \\
\hline
\end{tabular}




\subsection{COMMERCIAL STABILIZER DATA SHEETS}




\section{G3 ${ }^{\circledR}$ Pathway}

Liquid Polymer Stabilizer for DG \& Crushed Stone Mixes
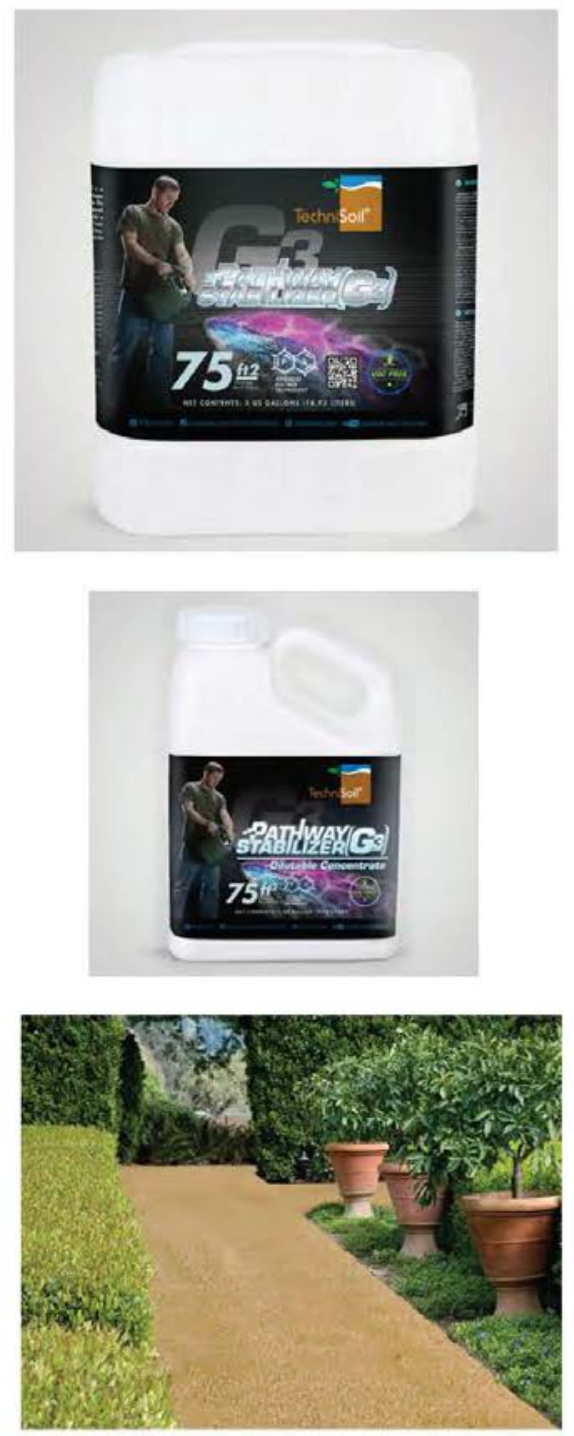

TechniSoilGlobal TechniSoil

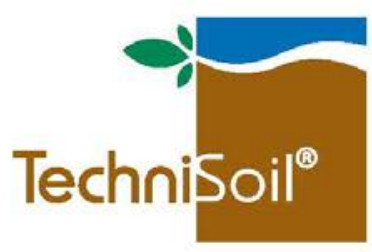

PRODUCT SUMMARY:

TechniSoil G3(8) Pathway Stabilizer (G3-PS) is a simple solution for creating custom pathways and patio areas. This eco-friendly liquid polymer stabilizer for decomposed granite (DG) and crushed stone materials yields a durable, dust-free surface in only a few basic steps. By bonding crushed aggregates and fines, G3-PS enhances natural surfaces for the modern landscape.

\section{PACKAGES:}

- 1-Gal bottle Dilutable Concentrate

- 5-Gal bottle - 55-Gal drum

\section{FEATURES \& BENEFITS:}

- Reduces tracking of loose materials

- Improves surface stability

- Easy to apply using standard equipment

- Minimizes dust, weeds, and erosion

- Low-maintenance

- Eco-friendly

\section{TYPICAL USES:}

- Pathways

- Patios

- Garden Trails

- Landscaping

COVERAGE:

- Mix 1-Gal Dilutable Concentrate bottle 4:1 with Water (Water : G3-PS)

- Up to $75 \mathrm{Ft}^{2}$ Per 5 Gallons

TechniSoil.com

877.356-2250 Mon - Fri: 7AM - 4PM (PST) 


\section{TechniSoil G3® Pathway Stabilizer}

1. PRODUCT \& COMPANY IDENTIFICATION

2. COMPOSITION INFORMATION ON INGREDIENTS

3. HAZARDS IDENTIFICATION

4. FIRST AID MEASURES

5. FIRE FIGHTING MEASURES
TRADE NAME: TechniSoil Global, Inc. PRODUCT NAME: G3@ Pathway Stabilizer DISTRIBUTED BY:

TechniSoil Global, Ine

5660 Westside Rd. Redding, CA 96001

Toll Free: 877.356 .2250

\begin{tabular}{|l|l|l|}
\hline COMPONENT: & RANGE: & CAS NO: \\
\hline Proprietary Polymer Blend & $5.8 \%-30.8 \%$ & Not Hazardous \\
\hline Water & $69.2 \%-94.2 \%$ & Not Hazardous \\
\hline \multicolumn{3}{|l|}{ Volatile organic compound (VOC) levels for this product are < $=5 \mathrm{~g} / \mathrm{l}}$. \\
\hline $\begin{array}{l}\text { EMERGENCY OVERVIEW } \\
\text { PHYSICAL APPEARANCE: }\end{array}$ & $\begin{array}{l}\text { HAZARD SUMMARY: } \\
\text { CAUTION! }\end{array}$ \\
\hline $\begin{array}{l}\text { Form: Liquid } \\
\text { Color: White, Milky } \\
\text { Odor: Acrylic }\end{array}$ & $\begin{array}{l}\text { Inhalation of vapor or mist can cause headache, } \\
\text { nausea and irritation of the nose, throat, and lungs. } \\
\text { May cause eye and skin irritation }\end{array}$ \\
\hline
\end{tabular}

Potential Health Effects Primary Routes of Entry:

Inhalation, Eye contact, Skin contact

Eyes: Direct contact with material can cause the following: slight irritation Skin: Prolonged or repeated skin contact can cause the following: slight irritation Inhalation: Inhalation of vapor or mist can cause the following: irritation of nose, throat, and lungs headache nausea

- Inhalation: Move to fresh air.

- Skin contact: Wash with water and soap as a precaution. If skin irritation persists, call a physician.

- Eye contact: Rinse with plenty of water. If eye irritation persists, consult a specialist.

- Ingestion: Drink 1 or 2 glasses of water. Consult a physician if needed.

- Never give anything by mouth to an unconscious person.

- Flash point: Noncombustible

- Lower explosion limit: Not Applicable

- Upper explosion limit: Not Applicable

- Thermal decomposition: May yield acrylic monomers

- Suitable extinguishing media: Media appropriate for surrounding fire.

- Specific hazards during fire fighting: Material can splatter above $100 \mathrm{C} / 212 \mathrm{~F}$. Dried product can burn.

- Special protective equipment for fire-fighters: Wear self-contained breathing apparatus and protective suit. 


\section{TechniSoil G3® Pathway Stabilizer}

6. ACCIDENTAL

RELEASE MEASURES

7. HANDLING \& STORAGE

8. EXPOSURE CONTROLS / PERSONAL PROTECTION

\section{PERSONAL PRECAUTIONS}

Use personal protective equipment.

Keep people away from and upwind of spill/leak.

Material can create slippery conditions.

\section{ENVIRONMENTAL PRECAUTIONS}

Keep spills and cleaning runoff out of municipal sewers and open bodies of water.

\section{METHODS FOR CLEANING UP}

Contain spills immediately with inert materials (e.g., sand, earth). Transfer liquids and solid diking material to separate suitable containers for recovery or disposal.

\section{HANDLING}

Avoid contact with eyes, skin and clothing. Wash thoroughly after handling. Keep container tightly closed. Do not breathe vapors, mist or gas. Further information on storage conditions: Keep from freezing - product stability may be affected. Stir well before use.

\section{STORAGE}

Storage temperature: $40-90^{\circ} \mathrm{F}\left(4.44-32.2^{\circ} \mathrm{C}\right)$

Other data: Monomer vapors can be evolved when material is heated during processing operations. See SECTION 8, for types of ventilation required. NOTE: Formaldehyde will be generated under acidic conditions. Maintain adequate ventilation under these conditions to prevent exposure to formaldehyde above the Rohm and Haas $\mathrm{Co}$. recommended ceiling of $0.3 \mathrm{ppm}$.

EXPOSURE LIMIT(S)

Exposure limits are listed below, if they exist.

\section{COMPONENTS REGULATION LISTING TYPE VALUE}

Not Applicable

EYE PROTECTION: Safety glasses with side-shields Eye protection worn must be compatible with respiratory protection system employed.

HAND PROTECTION: The glove(s) listed below may provide protection against permeation. (Gloves of other chemically resistant materials may not provide adequate protection): Neoprene gloves published by the American Conference of Governmental Industrial Hygienists for information on the design, installation, use, and maintenance of exhaust systems. 
8. EXPOSURE CONTROLS / PERSONAL PROTECTION (CONTINUED)

9. PHYSICAL AND CHEMICAL PROPERTIES

10. STABILITY \& REACTIVITY
RESPIRATORY PROTECTION: A respiratory protection program meeting OSHA 1910.134 and ANSI Z88.2 requirements or equivalent must be followed whenever workplace conditions warrant a respirator's use. None required if airborne concentrations are maintained below the exposure limit listed in Exposure Limit Information. For airborne concentrations up to 10 times the exposure limit, wear a properly fitted NIOSH approved (or equivalent) half-mask, air-purifying respirator. Air-purifying respirators should be equipped with NIOSH approved (or equivalent) N95 filters. If oil mist is present, use R95 or P95 filters.

PROTECTIVE MEASURES: Facilities storing or utilizing this material should be equipped with an eyewash facility.

ENGINEERING MEASURE S: Use local exhaust ventilation with a minimum capture velocity of $100 \mathrm{ft} / \mathrm{min} .(0.5 \mathrm{~m} / \mathrm{sec}$. $)$ at the point of vapor evolution. Refer to the current edition of Industrial Ventilation: A Manual of Recommended Practice published by the American Conference of Governmental Industrial Hygienists for information on the design, installation, use, and maintenance of exhaust systems.

\section{APPEARANCE}

Form: liquid

Colour: white milky

Odor: acrylic

\begin{tabular}{|l|l|}
\hline COMPONENT & $7.0-9.0$ \\
\hline $\mathrm{pH}$ & $100^{\circ} \mathrm{C}\left(212.00^{\circ} \mathrm{F}\right)$ Water \\
\hline Boiling point/boiling range & $0^{\circ} \mathrm{C}\left(32^{\circ} \mathrm{F}\right)$ \\
\hline Melting point/range & Noncombustible \\
\hline Flash point & Not Applicable \\
\hline Lower explosion limit & Not Applicable \\
\hline Upper explosion limit & $\begin{array}{l}17.0 \mathrm{mmHg} \text { at } 20^{\circ} \mathrm{C} \\
(68.00 \\
\end{array}$ \\
\hline Vapour pressure & $<1.0 \mathrm{Water}$ \\
\hline Relative vapour density & Miscible \\
\hline Water solubility & $1.00-1.20$ \\
\hline Relative density & $250.000 \mathrm{mPa} . \mathrm{s}$ maximum \\
\hline Viscosity, dynamic & $<1.00 \mathrm{Water}$ \\
\hline Evaporation rate & $49-51 \%$ Water \\
\hline Percent volatility & $<=5 \mathrm{~g} / \mathrm{L}$ \\
\hline $\begin{array}{l}\text { Volatile organic compounds } \\
\text { (VOC) }\end{array}$ & \\
\hline
\end{tabular}

NOTE: The physical data presented above are typical values and should not be construed as a specification.

Hazardous reactions Materials to avoid None known. Stable There are no known materials which are incompatible with this product.

Polymerization Product will not undergo polymerization. 
11. TOXICOLOGICAL INFORMATION

12. ECOLOGICAL INFORMATION

13. DISPOSAL CONSIDERATIONS

14. TRANSPORT INFORMATION

15. REGULATORY INFORMATION
No data are available for this material. The information shown is based on profiles of compositionally similar materials.

\begin{tabular}{|l|l|}
\hline Acute oral toxicity & LD50 rat $>5,000 \mathrm{mg} / \mathrm{kg}$ \\
\hline Acute dermal toxicity & LD50 rabbit $>5,000 \mathrm{mg} / \mathrm{kg}$ \\
\hline Skin irritation & rabbit May cause transient irritation. \\
\hline Eye irritation & rabbit No eye irritation \\
\hline
\end{tabular}

THERE IS NO DATA AVAILABLE FOR THIS PRODUCT.

\section{ENVIRONMENTAL PRECAUTIONS}

Keep spills and cleaning runoff out of municipal sewers and open bodies of water. DISPOSAL WASTE CLASSIFICATION: When a decision is made to discard this material as supplied, it does not meet RCRA's characteristic definition of ignitability, corrosivity, or reactivity, and is not listed in 40 CFR 261.33. The toxicity characteristic (TC), however, has not been evaluated by the Toxicity Characteristic Leaching Procedure (TCLP). Coagulate the emulsion by the stepwise addition of ferric chloride and lime. Remove the clear supernatant and flush to a chemical sewer. For disposal, incinerate or landfill at a permitted facility in accordance with local, state, and federal regulations.

\begin{tabular}{|l|l|}
\hline DOT & Not regulated for transport \\
\hline IMO/IMDG & Not regulated (Not hazardous) \\
\hline
\end{tabular}

\begin{tabular}{|c|c|}
\hline $\begin{array}{l}\text { WORKPLACE } \\
\text { CLASSIFICATION }\end{array}$ & $\begin{array}{l}\text { This product is considered non-hazardous } \\
\text { under the OSHA Hazard Communication Standard } \\
\text { (29CFR 1910.1200). This product is not a 'controlled } \\
\text { product' under the Canadian Workplace } \\
\text { Hazardous Materials Information System (WHMIS). }\end{array}$ \\
\hline $\begin{array}{l}\text { SARA TITLE III: SECTION } \\
\text { 311/312 CATEGORIZATIONS } \\
\text { (40CFR370): }\end{array}$ & $\begin{array}{l}\text { This product is not a hazardous chemical under } 29 \text { CFR } \\
1910.1200 \text {, and therefore is not covered by Title III of } \\
\text { SARA. }\end{array}$ \\
\hline $\begin{array}{l}\text { SARA TITLE III: SECTION } 313 \\
\text { INFORMATION (40CFR372) }\end{array}$ & $\begin{array}{l}\text { This product does not contain a chemical which is listed } \\
\text { in Section } 313 \text { at or above de minimis concentrations. }\end{array}$ \\
\hline $\begin{array}{l}\text { CERCLA INFORMATION } \\
(40 \text { CFR302.4) }\end{array}$ & $\begin{array}{l}\text { Releases of this material to air, land, or water are not } \\
\text { reportable to the National Response Center under the } \\
\text { Comprehensive Environmental Response, Compensa- } \\
\text { tion, and Liability Act (CERCLA) or to state and local } \\
\text { emergency planning committees under the Superfund } \\
\text { Amendments and Reauthorization Act (SARA) Title III } \\
\text { Section } 304 \text {. }\end{array}$ \\
\hline
\end{tabular}




\section{TechniSoil G3® Pathway Stabilizer}

15. REGULATORY INFORMATION (CONTINUED)

\section{OTHER INFORMATION}

\begin{tabular}{|l|l|}
\hline $\begin{array}{l}\text { US. TOXIC SUBSTANCES } \\
\text { CONTROL ACT (TSCA): }\end{array}$ & $\begin{array}{l}\text { All components of this product are in compliance with } \\
\text { the inventory listing requirements of the U.S. Toxic } \\
\text { Substances Control Act (TSCA) Chemical Substance } \\
\text { Inventory. }\end{array}$ \\
\hline PENNSYIVANIA & $\begin{array}{l}\text { Any material listed as "Not Hazardous" in the CAS REG } \\
\text { NO. column of SECTION 2, Composition/Information } \\
\text { On Ingredients, of this MSDS is a trade secret under the } \\
\text { provisions of the Pennsylvania Worker and Community } \\
\text { Right-to-Know Act. }\end{array}$ \\
\hline
\end{tabular}

HAZARD RATING:

\begin{tabular}{|l|l|l|l|}
\hline & HEALTH & FIRE & REACTIVITY \\
\hline HMIS & 1 & 0 & 0 \\
\hline
\end{tabular}

\section{LEGEND}

\begin{tabular}{|l|l|}
\hline ACGIH & American Conference of Governmental Industrial Hygienists \\
\hline BAC & Butyl acetate \\
\hline OSHA & Occupational Safety and Health Administration \\
\hline PEL & Permissible Exposure Limit \\
\hline STEL & Short Term Exposure Limit (STEL) \\
\hline TLV & Threshold Limit Value \\
\hline TWA & Time Weighted Average (TWA) \\
\hline${ }^{\text {II" }}$ & Bar denotes a revision from prior SDS \\
\hline
\end{tabular}

The information provided in this Safety Data Sheet is correct to the best of our knowledge, information and belief at the date of its publication.

The information given is designed only as a guidance for safe handling, use, processing, storage, transportation, disposal and release and is not to be considered a warranty or quality specification.

The information relates only to the specific material designated and may not be valid for such material used in combination with any other materials or in any process, unless specified in the text. 


\section{SOILWORKS}

\section{Technical Data Sheet}

(1)
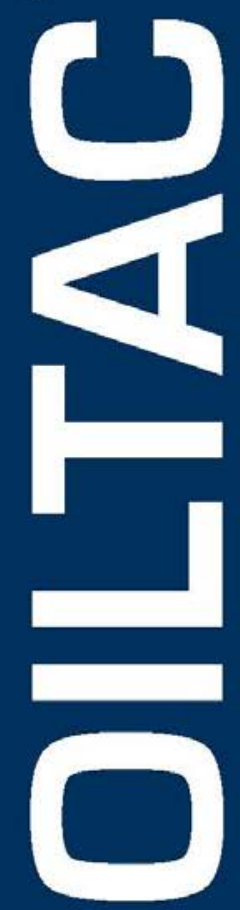

ஸ

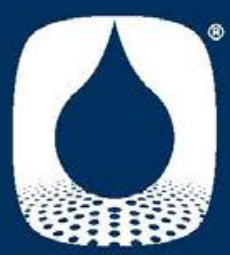

Chemical Description

Soiltac is an engineered eco-safe, biodegradable, liquid copolymer used to stabilize and solidify any soil or aggregate as well as erosion control and dust suppression.

When Soiltac is applied to the soil, the copolymer molecules coalesce and form bonds between the soil or aggregate particles. Long molecular structures link and cross-link together forming a flexible solid-mass that is durable and water resistant. The most durable soil stabilizer of Soilworks' product lines, Soiltac can be customized to achieve the results you need. Modest application rates are useful for dust suppression and erosion control by creating a three-dimensional cap or surface crust. Heavier application rates can generate qualities similar to cement, useful for soil solidification and stabilization found in road building

Typical Physical Properties

\begin{tabular}{|l|l|}
\hline Form & Liquid \\
\hline Odor & Sweet (no oder once cured) \\
\hline $\mathrm{PH}$ & 5 \\
\hline Density & $8.8-9.1 \mathrm{lbs} /$ gal \\
\hline Viscosity@ $25^{\circ} \mathrm{C}$ & $<1,200 \mathrm{cps}$ \\
\hline Freeze Point & $-0^{\circ} \mathrm{C}$ \\
\hline
\end{tabular}

\section{Application}

Soiltac is normally applied topically to the surface at an initial rate of $0.004-20.0$ percent solution covering between 35 to $2,200 \mathrm{ft}$. Maintenance coats are normally applied at $30 \%$ of the initial application rate.

By adjusting the application rate, Soiltac can remain effective from weeks to several years.

Safety Precautions

For specific information on handling, safety and first aid, please review the Soiltac Safety Data Sheet (SDS).

Shipping

Soiltacis available in 5-gallon pails, 55-gallon drums, 275-gallon IBC Totes and in bulk.

800.545.5420 USA | 001.480.545.5454 International | www.soilworks.com | info@soilworks.com 


\section{Klingstone PATHS}

Klingstone Paths

Amber

\section{Technical Data Sheet}

\section{DESCRIPTION AND APPLICATION}

Klingstone Paths Amber is a light amber, aromatic, one- component polyurethane binder. It is a multi-purpose, high-performance, moisture cure adhesive that can be used on a wide variety of substrates wheregood elastomeric properties are needed. Klingstone Paths Amber is applied as a liquid and, once cured, binds aggregate to create a firm, cohesive, yet permeable surface.

\begin{tabular}{|c|c|}
\hline \multicolumn{2}{|l|}{ Reaction Profile } \\
\hline Drying Time $\left\{\right.$ Tack Free, $75^{\circ} \mathrm{F}, 60 \%$ relative humidity\} & $5-8$ hours \\
\hline \multicolumn{2}{|l|}{ Component Properties } \\
\hline Color & Light Amber \\
\hline Specific Gravity $\left\{74^{\circ} \mathrm{F}\right\}$ & 1.135 \\
\hline Viscosity $\left\{74^{\circ} \mathrm{F}\right\}$, ASTM D-1638 & $1150 \mathrm{cps}$ \\
\hline$\%$ Solids & $100 \%$ \\
\hline Weight per gallon & 9.436 lbs. \\
\hline \multicolumn{2}{|l|}{ Typical Physical Properties } \\
\hline Tear Strength, ASTM D624 & $988 \mathrm{lbs} / \mathrm{in}$ \\
\hline Tensile Modulus, ASTM D412 & $15.70 \mathrm{ksi}$ \\
\hline Tensile Strength, ASTM D412 & $5650 \mathrm{pg}$ \\
\hline Elongation, ASTM D412 & $292 \%$ \\
\hline
\end{tabular}

"Values given are not intended to be used in specific preparation

\section{RECOMMENDED HANDLING INSTRUCTIONS}

-Use only in well-ventilated areas.

-Wear chemically resistant rubber gloves, safety glasses, and protective clothing covering skin.

-Avoid prolonged or repeated contact with skin.

-In case of skin contact, wipe affected area with isopropyl alcohol, followed by soap and water.

-In case of eye contact, flush eyes with water for 15 minutes and consult a physician.

If swallowed or comes into contact with eyes, seek medical attention immediately.

-Refer to handling document.

Liquid polyurethanes are moisture sensitive. If the material is exposed to moisture, including moisture from the air, it will release $\mathrm{CO}^{2}$ gas. If placed in a sealed container, this gas can cause a dangerous buildup of pressure potentially resulting in injury or death. When the product is exposed to moisture, it will cause foaming, which will result in a weaker material.

\section{SAFETY}

Please refer to the SDS for all appropriate heal th and safety information.

Since Seller exercises no control over Buyers' application or use of the product manufactured by Seller

("product") and since materials used with the product may vary, it is understood that:

- THERE ARE NO WARRANTIES, EXPRESS OR IMPLIED, INQUDING ANY WARRANTIES OR MECHANTABILITY OR FOR ANY PARTICULAR PURPOSE.) While all data presented in Seller's technical data sheet is based on the best information available to Seller and believed correct, such data is not to be construed as a warranty that the product will conform to such specifications. Such technical data sheets are subject to change without notice. Since all urethane systems are organic, they will burn.

- Reported labora tory test results of the color stability in no way relates to the actual performance upon exposure to light sources. Seller shall not be liable for any damages resulting from ultraviolet light color degradation of any aromatic polyurethane systems manufactured or sold by Seller.

- The liability of the Seller shall not exceed the purchase price and the Buyer shall not be entitled to nor the Seller be liable for any consequential, incidental, indirect or special damages resulting in any manner from the furnishing of the product.

Klingstone Paths, LLC $\downarrow$ KlingstonePaths.com

Ph: 1-800-942-5151 — Fax: 828-456-9699 \Int'l: 828-456-9970 